$\mathbf{G} \mathbf{E} \mathbf{U} \mathbf{S}$
Report file no.

22298

GRøNLANDS GEOLOGISKE UNDERSøGELSE

Bulletin No. 128

Submarine fan sedimentation along fault scarps on tilted fault blocks

(Jurassic-Cretaceous boundary, East Greenland)

by

Finn Surlyk 


\section{Grønlands Geologiske Undersøgelse \\ (The Geological Survey of Greenland) \\ Øster Voldgade 10, DK-1350 Copenhagen K}

\section{Bulletins}

No. 113 Holocene history of the Greenland ice sheet based on radiocarbon-dated moraines in West Greenland. 1975 by N. W. Ten Brink. (Meddr Gronland 201,4).

D.kr. 40.00

No. 114 Ferri-sepiolite in hydrothermal calcite-quartz-chalcedony veins on Nûgssuaq in West Greenland. 1974 by K. Binzer \& S. Karup-Møller. (Meddr Gronland 201,5). $\quad$ D.kr. 12.50

No. 115 The Hurry Inlet granite and related rocks of Liverpool Land, East Greenland. 1975 by K. Coe.

D.kr. 26.00

No. 116 The crystal habit of naujakasite. 1975 by Ole V. Petersen and Steen Andersen. The crystal structure of naujakasite. 1975 by Riccardo Basso, Alberto Dal Negro, Antonio Della Giusta \& Luciano Ungaretti.

D.kr. 20.00

No. 117 Organic compounds from the Rhaetic-Liassic coals of Scoresby Sund, East Greenland. 1975 by K. R. Pedersen \& J. Lam.

D.kr. 16.00

No. 118 The South Qôroq Centre nepheline syenites, South Greenland. Petrology, felsic mineralogy and petrogenesis. 1976 by D. Stephenson.

D.kr. 25.00

No. 119 Carbonates et stromatolites đu sommet du Groupe d'Eleonore Bay (Précambrien terminal) au Canning Land (Groenland oriental). 1976 par J. Bertrand-Sarfati \& R. Caby. D.kr. 45.00

No. 120 Early Tertiary flood basalts from Haregen and western Nügssuaq. West Greenland. 1976 by N. Hald.

D.kr. 30.00

No. 121 Early Silurian (Late Llandovery) rugose corals from western North Greenland. 1977 by R. A. McLean.

D.kr. 46.00

No. 122 Gardiner intrusion, an ultramafic complex at Kangerdlugssuaq, East Greenland. 1977 by W. Frisch \& H. Keusen.

D.kr. 80.00

No. 123 Stratigraphy, tectonics and palaeogeography of the Jurassic sediments of the areas north of Kong Oscars Fjord, East Greenland. 1977 by F. Surlyk.

D.kr. 50.00

No. 124 The Fiskenæsset complex. West Greenland Part III Chemistry of silicate and oxide minerals from oxide-bearing rocks, mostly from Qeqertarssuatsiaq. 1977 by I. M. Steele, F. C. Bishop, J. V. Smith \& B. F. Windley.

D.kr. 27.00

No. 125 Petrology of the late lavas of the Eriksfjord Formation, Gardar province, South Greenland. 1977 by J. Gutzon Larsen.

D.kr. 25.00

No. 128 Submarine fan sedimentation along fault scarps on tilted fault blocks (Jurassic-Cretaceous boundary, East Greenland). 1978 by F. Surlyk.

Bulletins up to no. 114 were also issued as parts of Meddelelser om Gronland, and are available from Nyt Nordisk Forlag - Arnold Busck, Kobmagergade 49, DK-1150 Copenhagen K, Denmark. 
Denne afhandling er af det naturvidenskabelige fakultet ved Københavns universitet antaget til offentlig at forsvares for den naturvidenskabelige doktorgrad.

København, den 18. november 1977.

Eigil Prastgaard

h. a. dec.

Forsvaret finder sted torsdag d. 1. maj 1978 kl.14 præcis i universitetsannekset, auditorium A, Studiestræde 6 o.g. 


\section{GRøNLANDS GEOLOGISKE UNDERSØGELSE}

Bulletin No. 128

Submarine fan sedimentation along fault

scarps on tilted fault blocks

(Jurassic-Cretaceous boundary, East Greenland)

by

Finn Surlyk

One map in pocket 


\begin{abstract}
In late Jurassic times large-scale faulting, which partly occurred along old lines of weakness, fragmented the East Greenland shelf into several westerly tilted blocks. The sediments of the syntectonic Middle Volgian-Valanginian Wollaston Forland Group were deposited along and away from the fault scarps formed at the uptilted western margin of each block.

To the west the group comprises thick syntectonic clastic wedges of submarine rock-fall breccias which pass laterally into thick conglomerates and sandstones deposited by various types of sediment gravity flow. Further to the east these facies pass rapidly into mudstones. The depositional regime was characterized by repeated fault activity resulting in deepening of the depositional basins, followed by rapid erosion of borderlands and sedimentation of very coarse clastic sediments on a narrow coastal fringe of fan-deltas leading into submarine fans. This pattern continued into Ryazanian time (early Lower Cretaceous), and in the Valanginian a major regional transgression initiated an open shelf where light grey mudstones and sandstone turbidites were deposited. These Middle Volgian to Valanginian sediments are interpreted as showing a progressively collapsing and submerging platform.

The model presented for submarine sedimentation along fault scarps on tilted fault blocks displays the same facies associations as the one for deep-sea fans. Distinguishing characters are seen in the internal distribution of facies. The sediment prism is arranged in several hundred metres thick fining-upward megacycles corresponding to major phases of faulting and down-tilting of fault blocks. They also indicate gradually diminishing sediment supply following rapid erosion and retreat of borderlands. Megacycles are internally composed of fining-upward cycles a few metres to tens of metres thick. These cycles reflect progressive filling and abandonment of inner and midfan channels. The very coarse-grained proximal units wedge out very rapidly in a distal direction where the seaward dipping fan slope is checked due to the dip slope of the opposite fault block.
\end{abstract}

Author's address:

Geologisk Museum

Øster Voldgade 5-7

DK-1350 København K, Danmark 


\section{CONTENTS}

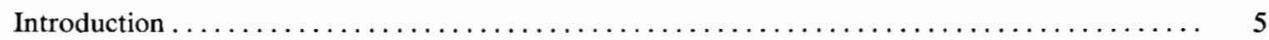

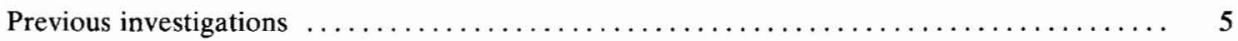

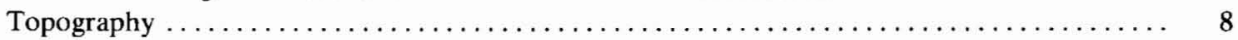

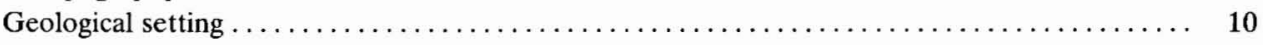

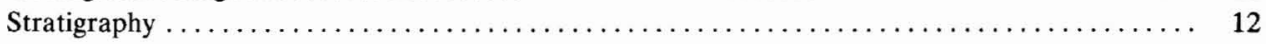

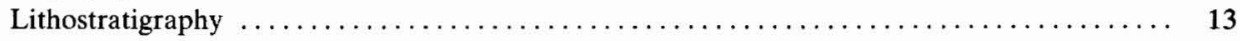

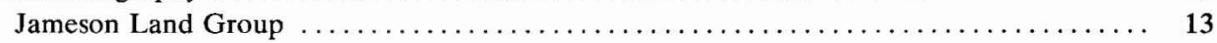

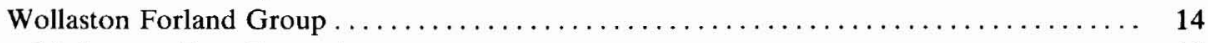

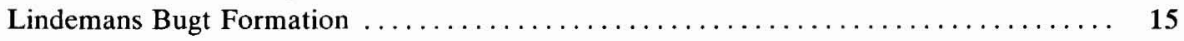

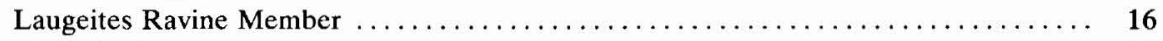

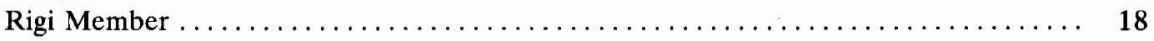

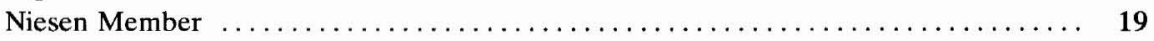

Palnatokes Bjerg Formation $\ldots \ldots \ldots \ldots \ldots \ldots \ldots \ldots \ldots \ldots \ldots \ldots \ldots \ldots \ldots \ldots \ldots \ldots \ldots \ldots \ldots, 20$

Young Sund Member $\ldots \ldots \ldots \ldots \ldots \ldots \ldots \ldots \ldots \ldots \ldots \ldots \ldots \ldots \ldots \ldots \ldots \ldots \ldots \ldots \ldots, 22$

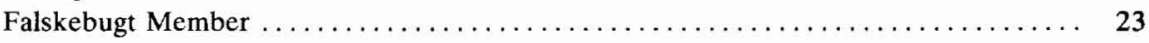

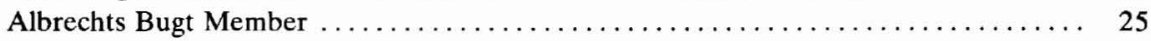

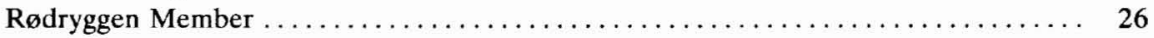

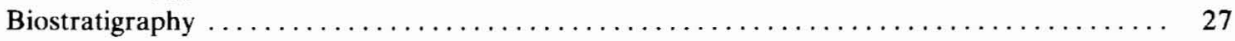

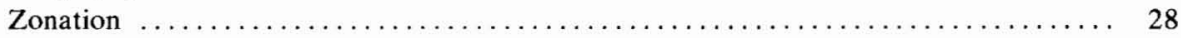

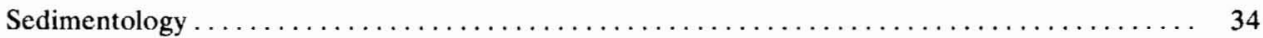

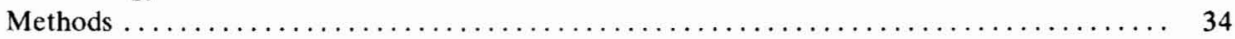

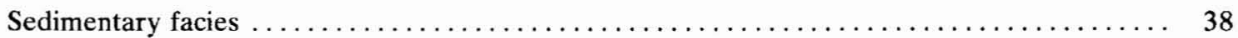

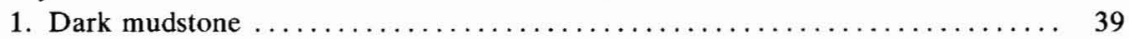

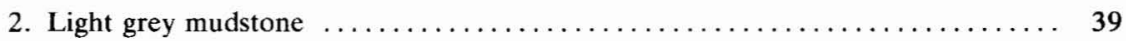

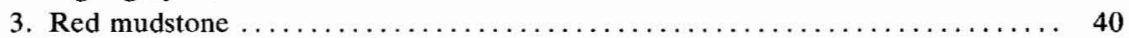

4. Interlaminated mudstone and fine sandstone $\ldots \ldots \ldots \ldots \ldots \ldots \ldots \ldots \ldots, 41$

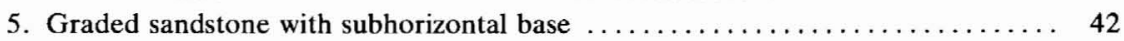

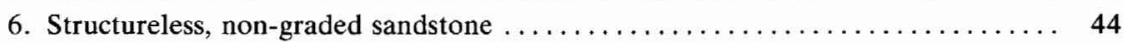

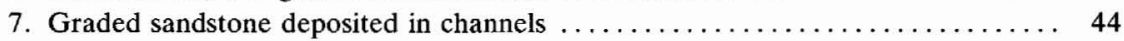

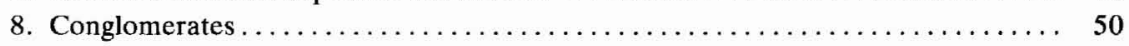

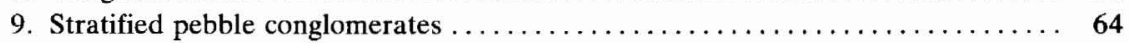

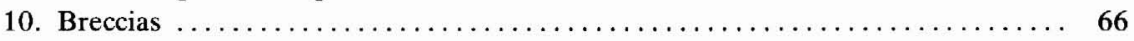

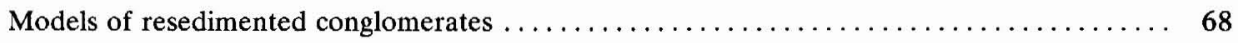

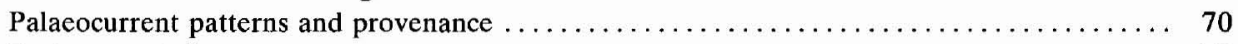

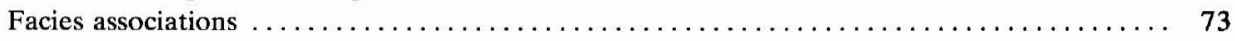

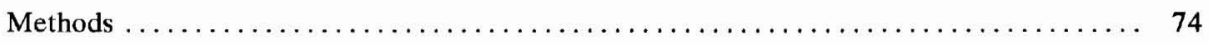

Facies associations of the Lindemans Bugt Formation $\ldots \ldots \ldots \ldots \ldots \ldots \ldots \ldots \ldots \ldots \ldots \ldots$

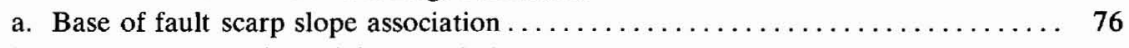

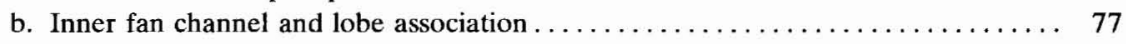

d. Inner fan interchannel and midfan association $\ldots \ldots \ldots \ldots \ldots \ldots \ldots \ldots \ldots, 80$

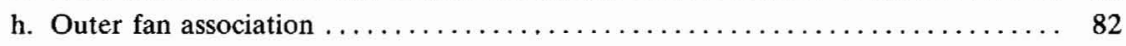

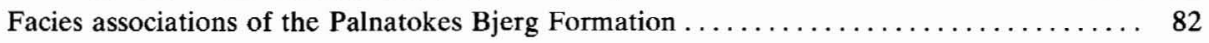

a. Base of fault scarp slope association $\ldots \ldots \ldots \ldots \ldots \ldots \ldots \ldots \ldots \ldots \ldots \ldots \ldots \ldots \ldots \ldots, \quad 82$ 


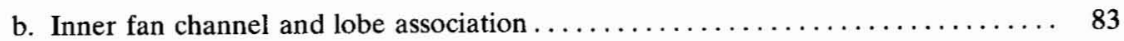

e. Midfan and inner fan interchannel association $\ldots \ldots \ldots \ldots \ldots \ldots \ldots \ldots \ldots, 83$

f. Distal midfan and outer fan association $\ldots \ldots \ldots \ldots \ldots \ldots \ldots \ldots \ldots \ldots \ldots \ldots \ldots$

g. Basin and shoals on submerged block crest association $\ldots \ldots \ldots \ldots \ldots \ldots \ldots . \ldots 5$

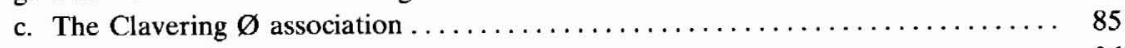

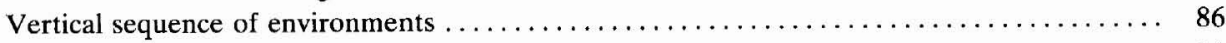

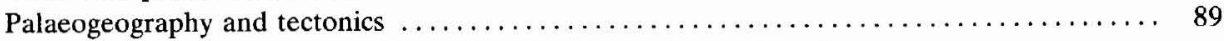

Tectonic-sedimentologic model for submarine fan sedimentation along

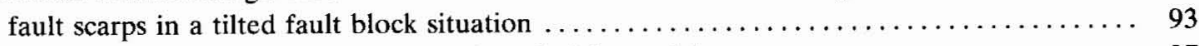

Comparison with the submarine fan - abyssal plain model $\ldots \ldots \ldots \ldots \ldots \ldots \ldots \ldots \ldots \ldots . \ldots 7$

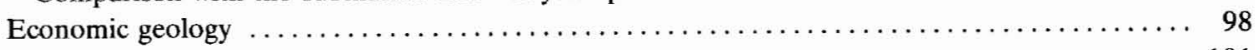

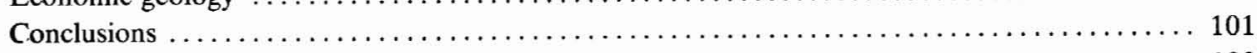

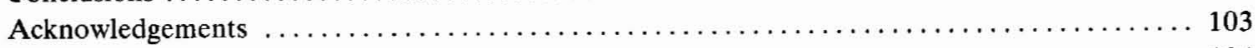

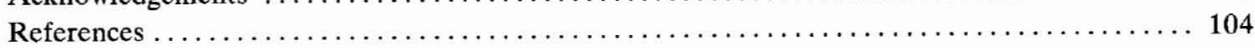

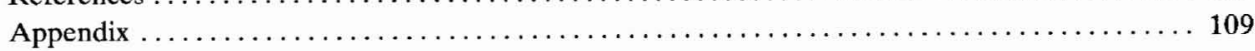

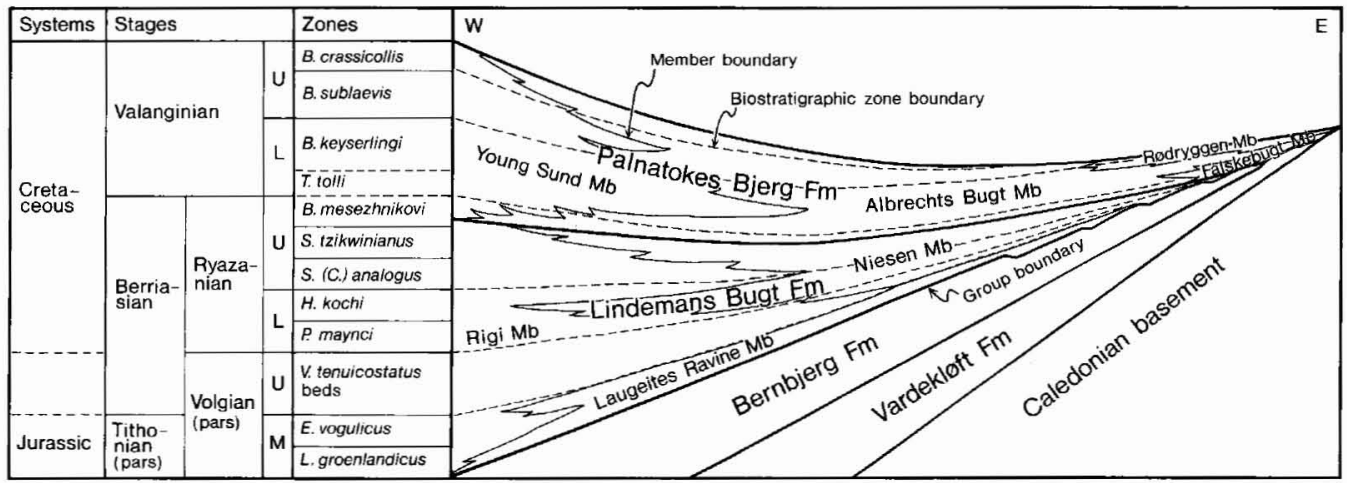

Fig. 1. Stratigraphic scheme of the Middle Volgian - Valanginian sedimentary rocks of the Wollaston Forland Group, East Greenland. 


\section{INTRODUCTION}

The stratigraphy, sedimentary processes and depositional environments of the syntectonic late Jurassic - early Cretaceous sediments in the Wollaston Forland area in northern East Greenland $\left(74-75^{\circ} 30^{\prime} \mathrm{N}\right)$ form the subject of this paper (figs $1,2)$. The work is a continuation of earlier studies of contemporaneous sediments in the years $1968-71$ in the Jameson Land area $\left(70^{\circ} 30^{\prime}-72^{\circ} \mathrm{N}\right.$ ) (Surlyk, 1973, 1975b).

The facies in question are placed in the Wollaston Forland Group and constitute a clastic wedge which attains a maximum thickness of about $3000 \mathrm{~m}$ in the west and thins eastwards over $10-25 \mathrm{~km}$ to a thickness of $0-50 \mathrm{~m}$. The wedge was deposited in approximately 10-12 m.y., signifying very high rates of deposition.

The sediments are here interpreted as having been deposited in a system of coalescent submarine fans along roughly $\mathrm{N}-\mathrm{S}$ trending fault-scarps. The scarps were formed by strong antithetic block faulting which began in mid Volgian times and continued through the Ryazanian and Valanginian. This phase of rifting and crustal attenuation can be recognized along the entire northern North Atlantic continental margin and is also characteristic of the northern North Sea grabens.

Field work in the Wollaston Forland area was carried out in the period from 5th July to 26th August, 1974 with a total of 39 active field days. I was accompanied in the field by Lars Clemmensen, who measured some of the sections illustrated in this paper, but otherwise mainly studied the rocks of the Vardekløft Formation. The work was concentrated on Wollaston Forland ( 5 camps) and Kuhn $\varnothing$ (2 camps) whereas Clavering $\varnothing$, Th. Thomsen Land and Hochstetter Forland were visited on one-day helicopter flights (fig. 2). On Wollaston Forland four camps were placed along an east-west line at a right angle to the north-south trending faults, which are the most important structural elements delineating the Mesozoic basins, and one camp in south-west Wollaston Forland. This camp distribution was planned in order to achieve an adequate picture of the basin geometry and facies changes from the fault scarps which formed the ancient coastlines to the offshore regions. The investigation of central Wollaston Forland was more in the nature of a reconnaissance as the small lateral changes along the coastlines were considered less important.

The geological map produced by Vischer (1943) is of high standard and only a few errors were found.

Wollaston Forland is well covered by vertical aerial photographs except, unfortunately, for the northern coastal area where the best sections are located and where the work was concentrated. Kuhn $\varnothing$ is covered by vertical colour aerial photographs of rather good quality.

\section{Previous investigations}

The coastal area of northern East Greenland, approximately between $74^{\circ}$ and $76^{\circ} \mathrm{N}$, has a long exploration history which has been reviewed by Koch $(1929,1939)$, Donovan (1957) and recently by Haller (1971). 


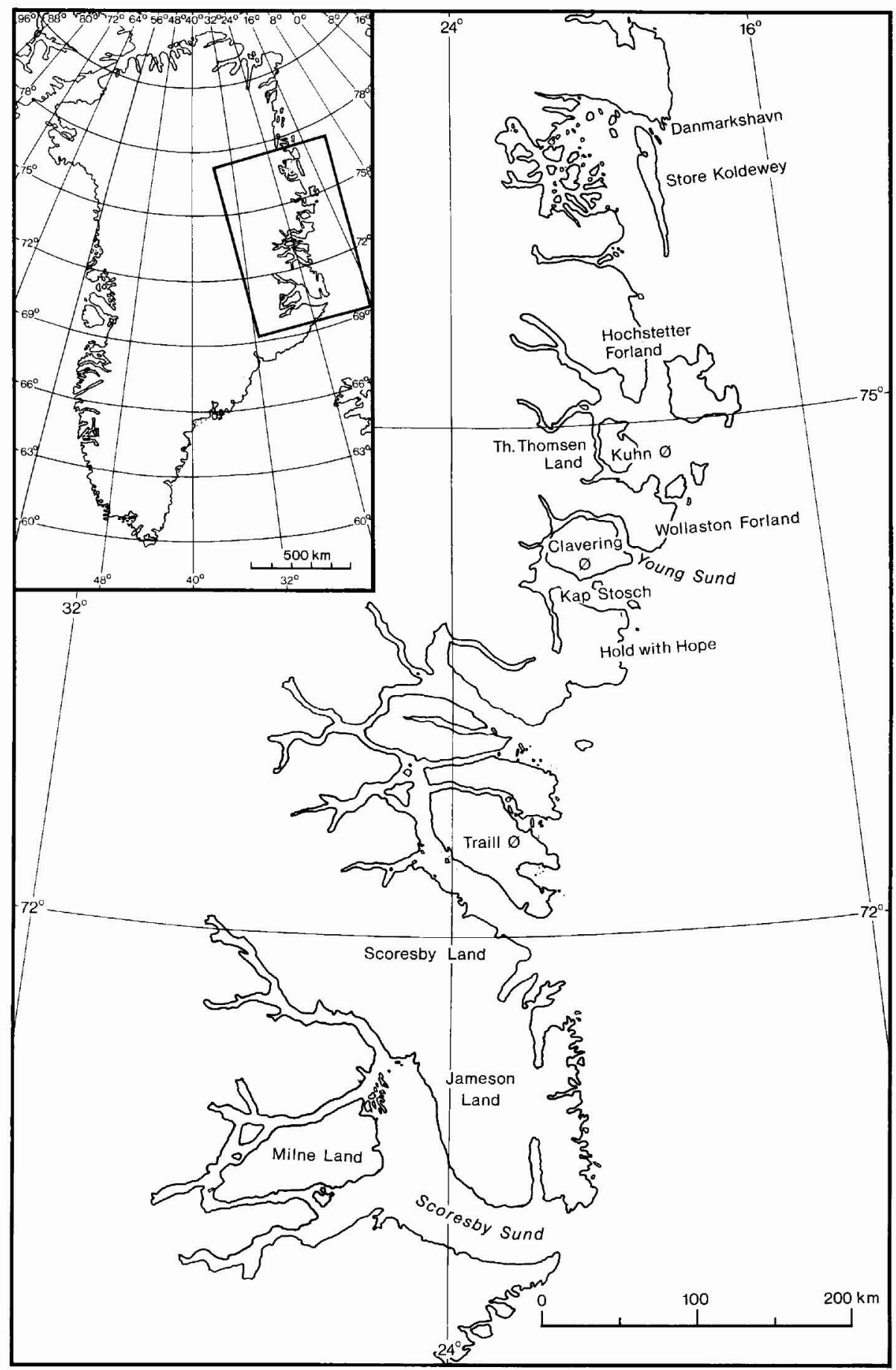

Fig. 2. Locality map of central East Greenland. 
The first expedition to study Jurassic and Cretaceous rocks of the northern east coast was the Second German North Polar Expedition led by Captain K. Koldewey in 1870-71. In 1870 one of the geologists of the expedition, J. von Payer, discovered sediments of Valanginian age on the east coast of Kuhn $\varnothing$; and the fauna, mainly comprising different species of the bivalve Buchia, was described by Toula (1874). The same locality was visited by Koch (1929) on his first expedition to East Greenland in 1926-27. He made a number of sledge journeys from Scoresby Sund $\left(70^{\circ} 30^{\prime} \mathrm{N}\right)$ to Danmarkshavn $\left(76^{\circ} 45^{\prime} \mathrm{N}\right)$ and was the first to gain an overall impression of the distribution of the Jurassic and Cretaceous rocks in East Greenland. He demonstrated the presence of Portlandian (later shown to be Kimmeridgian) rocks on eastern Kuhn $\varnothing$ and of Kimmeridgian and Valanginian rocks on Wollaston Forland.

Coarse Valanginian conglomerates were discovered in 1929 in south-west Wollaston Forland by Rosenkrantz (1932).

The Danish Three-Year Expedition led by L. Koch left Copenhagen in June 1931. Some of the members worked in Mesozoic rocks and the results were published by Frebold (1932a, b, 1933). Frebold himself worked in south-west Wollaston Forland in sediments of middle to late Jurassic and early Cretaceous age, but his results have justifiably been criticized by Maync (1949). Frebold also visited Hochstetter Forland, where he established the late Jurassic age of the coal-bearing sandstones discovered by the Second German North Polar Expedition (Frebold, 1932b). His results have been revised by later authors (Clemmensen \& Surlyk, 1976).

The next expedition to the area, again led by L. Koch, was the Danish Two-Year Expedition. During this expedition Kuhn $\varnothing$, Th. Thomsen Land, Wollaston Forland, Clavering $\varnothing$ and Hold with Hope were mapped by Vischer (1943) and the stratigraphy and broad facies pattern unravelled by Maync $(1947,1949)$. Their work is of high quality and only a few discrepancies have been found. Vischer, furthermore, studied the role of antithetic block faulting in controlling sedimentation. Maync first published his detailed stratigraphical accounts after the Second World War and as a consequence Vischer's paper is somewhat hampered by lack of stratigraphical information, especially on the Volgian-Ryazanian-Valanginian part of the sequence. Though very detailed and comprehensive, Maync's papers contain no descriptions or illustrations of fossils, and exact biostratigraphical ages are therefore unknown. Furthermore, his stratigraphical nomenclature is not systematic, changing through his papers from a mainly lithostratigraphic to a bio- or even chronostratigraphic emphasis. Spath (1952) published a new ammonite genus of Ryazanian age collected by Maync in northern Wollaston Forland.

Wollaston Forland was briefly visited in 1952 by A. J. Standring and E. W. Roberts, in 1956 by F. Perrenoud and D. Roy and in 1957 by D. T. Donovan who also visited south-west Kuhn $\varnothing$. The Volgian and Ryazanian ammonites collected by these geologists were described by Donovan in 1964.

Results of the recent field work have been published on the stratigraphy (Surlyk \& Clemmensen, 1975a; Sykes \& Surlyk, 1976; Surlyk, 1977) and sedimentology (Surlyk, 1975a, b; Surlyk \& Clemmensen, 1975b, in press; Clemmensen \& Surlyk, 1976) of the Jurassic and early Cretaceous sediments. 


\section{Topography}

Jurassic and early Lower Cretaceous rocks crop out between $74^{\circ} \mathrm{N}$ and $75^{\circ} 30^{\prime} \mathrm{N}$ on north-east Clavering $\varnothing$, on Wollaston Forland, on the east and west coasts of Kuhn $\varnothing$ and along a narrow coastal strip on Th. Thomsen Land (fig. 3, plate 9). Between the areas of sedimentary rocks are north-south trending ridges of Caledonian crystalline basement constituting the elevated eastern margins of tilted fault blocks. The highest parts of southern Kuhn $\varnothing$, north-east Clavering $\varnothing$ and large parts of Wollaston Forland are covered by almost horizontal Tertiary plateau basalts.

The sedimentary rocks of Th. Thomsen Land are exposed as a narrow, low-lying, down-faulted strip along the coast. The topographically highest situated sedimentary rocks occur at the south-east point of the peninsula at about $400 \mathrm{~m}$ altitude, whereas the remaining sections are situated almost at sea-level. Degree of exposure is poor and the outcrops are difficult to find mainly because of coverage by solifluction or Quaternary deposits.

On the east coast of Kuhn $\emptyset$ the rocks occur in a triangular-shaped down-faulted area. The almost north-south trending fault scarp is a very prominent morphological feature as it separates the even, low relief sedimentary plateau to the east from the jagged, alpine Caledonian crystalline rocks to the west, which are more than $1000 \mathrm{~m}$ high. The eastern plateau is totally covered with Quaternary deposits, and good exposures of Upper JurassicLower Cretaceous mudstones are confined to the beach and to a few valleys leading to the beach.

The surface of the Caledonian basement was peneplaned and tilted to the west-south-west in pre-Bathonian time and Jurassic rocks are consequently found on the gently sloping surface of the basement. These areas have a rounded, smooth topography and the sediments are mainly covered by solifluction material or by scree from overlying plateau basalts. Good exposures are found at the head of Payers Dal on the south coast, but elsewhere the sediments are relatively poorly exposed. The highest summits, Bernbjerg and Baselbjerg, reach altitudes of about $800 \mathrm{~m}$ and are covered by thin plateau basalts. East of Payers Dal Jurassic sediments are preserved on three summits all reaching about $1000 \mathrm{~m}$ and topped by plateau basalts. On the southernmost peak, Kingofjeld, good sections are found almost from the valley bottom to the base of the basalts at about $840 \mathrm{~m}$.

Wollaston Forland is generally low lying and poorly exposed. Only in the north-west part do a few valleys show magnificent and often very steep exposures through Volgian-Ryazanian rocks. Cardiocerasdal to the south-west at Young Sund also shows extremely well exposed sections through Bathonian to Aptian sediments. Central and eastern Wollaston Forland is low and wet and contains poorly exposed Upper Jurassic and Lower Cretaceous mudstones.

Clavering $\varnothing$ has only a small fault block containing well exposed Jurassic - early Cretaceous sediments along the coast.

Compared with the Jameson Land - Scoresby Land area in central East Geenland, the Wollaston Forland region is lower lying, has gentler and more rounded topography, and is covered to a considerable degree by solifluction or Quaternary deposits.

Good sections are rare and it is often very difficult to follow beds between two well exposed sections. For litho- and biostratigraphical purposes the degree of exposure is usually sufficient, whereas it is rather unsatisfactory for the purpose of detailed sedimentological studies. 


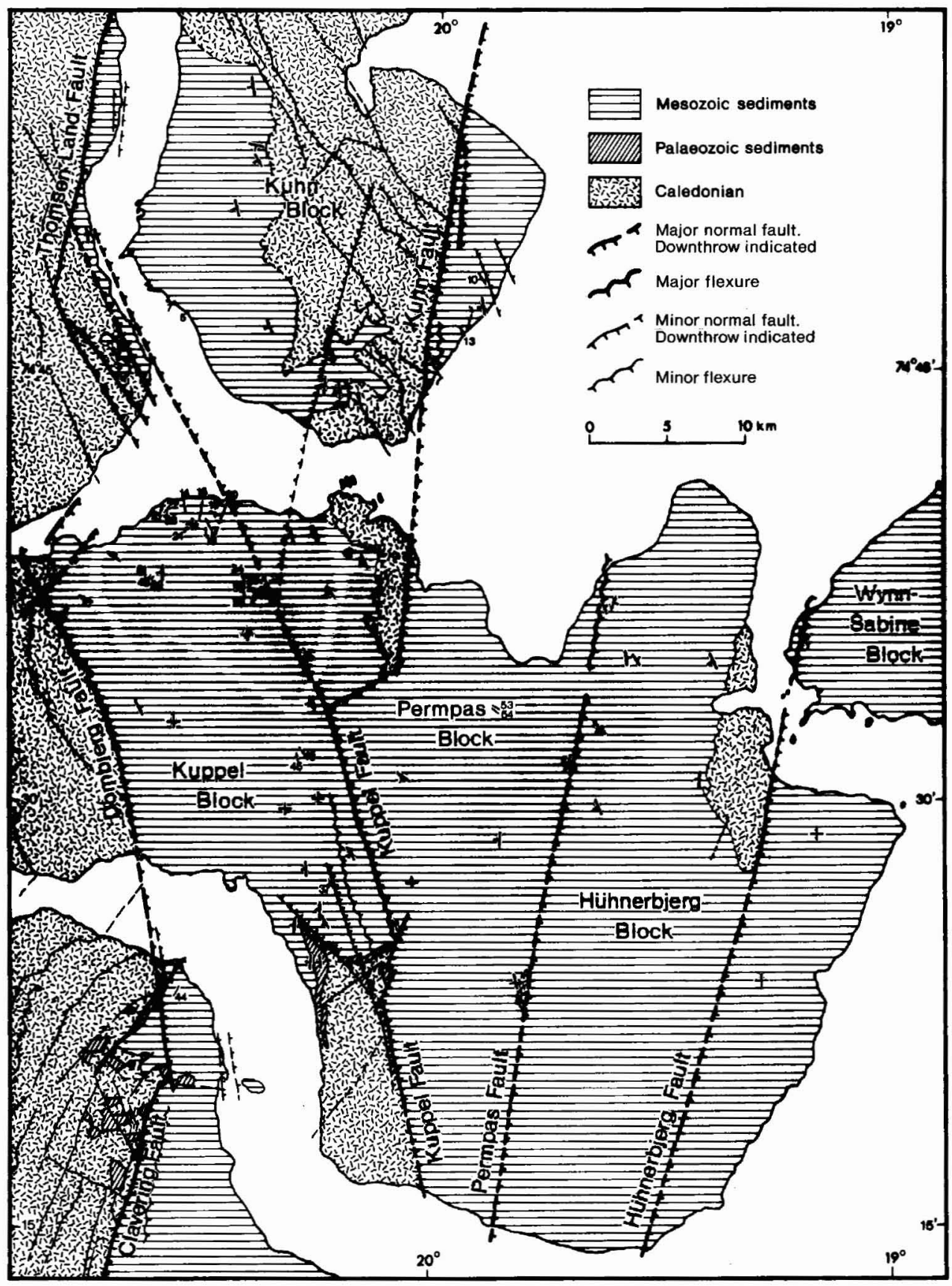

Fig. 3. Geological map of the Wollaston Forland area showing distribution of Caledonian basement, Palaeozoic and Mesozoic sediments, and the faults bordering the tilted fault blocks. Position of the measured sections is indicated by their number. 


\section{GEOLOGICAL SETTING}

Following the Caledonian orogeny, during the Devonian the mountainous area underwent a period of erosion and minor earth movements (Haller, 1971).

A pattern of repeated block faulting along $\mathrm{N}-\mathrm{S}$ lines and tilting of fault blocks to the west started as early as the Devonian. According to Bütler (1957) the Devonian sedimentary basin was bordered to the west by en echelon faults trending parallel to the East Greenland continental margin. In post-Dinantian times a major $\mathrm{N}-\mathrm{S}$ trending fault was formed with a considerable downthrow to the east, and named the Post Devonian Main Fault by Vischer (1943). The downthrown eastern block was tilted to the west and a tectonic depression was formed in the Clavering $\varnothing$ and Copeland Fjord area. The Post Devonian Main Fault is the main structural feature from early Carboniferous time and onwards. Apparently, none of the Mesozoic transgressions penetrated the hinterland to the west of it.

In the Namurian the uplifted western highlands were strongly eroded and coarse arkoses rapidly filled the tectonic depressions. The arkoses wedge out to the east.

The Namurian deposits in turn were strongly eroded in pre-Zechstein time so that Zechstein overlie Caledonian crystalline basement rocks in the north-eastern part of the region and Namurian to the west. This overstepping is due to an episode of block faulting and tilting in the period between the Namurian and the Zechstein, followed by the formation of a pre-Zechstein peneplane.

The shallow Zechstein sea transgressed over the flat erosion surface except in the area now occupied by northern Wollaston Forland where the coast of a supposed northern land-mass was situated (Maync, 1940).

Renewed faulting took place in the earliest Triassic and the coarse deposits of this age contain exotic blocks of Permian limestones and dolomites on Kap Stosch (north coast of Hold with Hope) and at Brinkley Bjerg in southern Clavering $\varnothing$. Young Sund formed a bay limited to the west by fault scarps in eastern Clavering $\varnothing$ and to the north by a land-mass.

Uplift of this land-mass took place after the Triassic. On Kuhn $\varnothing$ and the northern Wollaston Forland the land surface at the beginning of the Jurassic was composed of Caledonian crystalline rocks. However, in south Wollaston Forland it was composed of Permian sediments, and on Clavering $\varnothing$ early Triassic sediments were preserved in south-westerly tilted fault blocks.

A regional transgression began in the Middle Jurassic (Bathonian) and continued in a series of fault controlled steps until Late Jurassic (Middle Volgian) times (Sykes \& Surlyk, 1976; Surlyk, 1977; Surlyk \& Clemmensen, in press). Exotic Permian blocks in the mid-Jurassic Pelion Member on east Clavering $\varnothing$ show that the Clavering Fault still formed the coastline. Mid-Jurassic seas may never have covered eastern Wollaston Forland and the higher eastern parts of the fault blocks might have been islands or peninsulas.

The Bathonian-Callovian sediments everywhere comprise shallow marine, and 


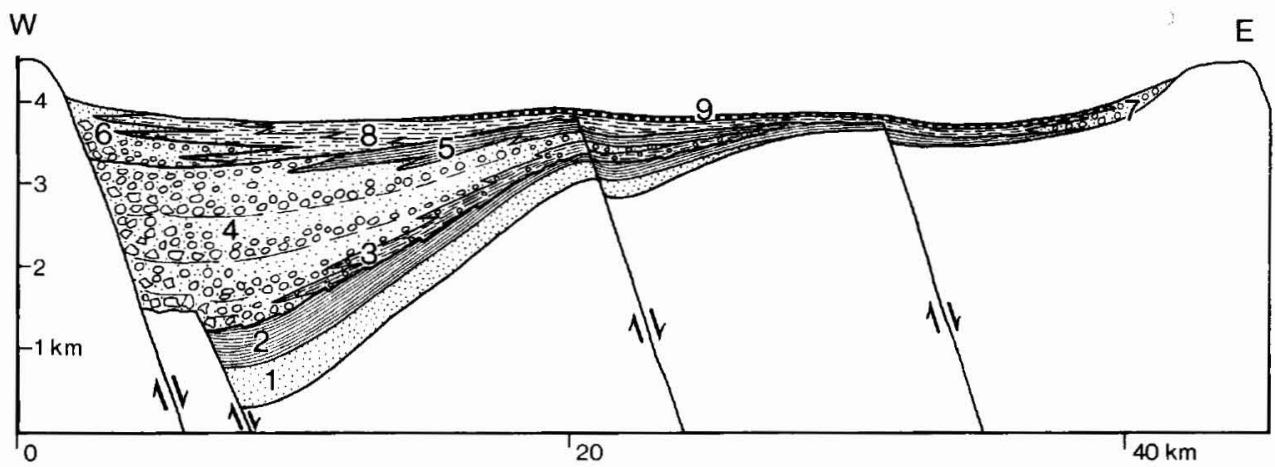

Fig. 4. W-E cross-section through northern Wollaston Forland restored to early Cretaceous situation. 1: Vardekløft Formation (Middle Jurassic), 2: Bernbjerg Formation (Upper Oxfordian-Lower Kimmeridgian). 3-5: Lindemans Bugt Formation (Middle-Upper Volgian); 3: Laugeites Ravine Member, 4: Rigi Member, 5: Niesen Member. 6-9: Palnatokes Bjerg Formation (Ryazanian-Valanginian); 6: Young Sund Member, 7: Falskebugt Member, 8: Albrechts Bugt Member, 9: Rødryggen Member.

probably tidally influenced sandstones. A period of down-faulting took place ir the Early Oxfordian resulting in deposition of mudstones and sandstones in the basin centre. As a result of further down-faulting in the Late Oxfordian the sea covered still larger areas and the sediments are dominantly fine-grained dark mudstones deposited under euxinic conditions below wave-base. Occasional sandy intercalations in both western and eastern Wollaston Forland show, however, the influence of the bordering land-masses. This depositional regime persisted through the main part of the Kimmeridgian (Sykes \& Surlyk, 1976; Surlyk, 1977; Surlyk \& Clemmensen, in press).

At the end of the Jurassic strong faulting along old as well as new fault-lines occurs and an 'antithetische Schollentreppe' (Vischer, 1943) was formed. The eastern blocks are down-faulted, but tilted to the west in such a way as to compensate for the vertical displacement.

The fault-activity commenced in the Middle Volgian, continued through the Ryazanian and faded out in the Valanginian. The higher parts of the elevated crests of the blocks were emergent during Volgian-Ryazanian times when only the topographically deepest tectonic grooves were occupied by narrow fjords. Strong erosion on the elevated block crests generated the breccias, conglomerates and sandstones, which fill this trough. The sea encroached in the Valanginian, but the Clavering - Dombjerg Fault still formed the high and steep western coastline (figs $3,4)$.

Following the Valanginian a phase of uplift occurred and the Hauterivian and Barremian were periods of emergence and erosion.

The structural outline of the Mesozoic of northern East Greenland was unravelled by Vischer (1943) with the support of the stratigraphic data of Maync (1947, 
1949), and recent research has added only a few additions to this picture. It has nevertheless been possible to consider sedimentation in relation to the North Sea rift system. The rifting was probably caused by crustal doming during Palaeozoic and especially Mesozoic times (Vischer, 1943) and the intense faulting in latest Jurassic - earliest Cretaceous times has been related to the initial opening of the Atlantic Ocean (e.g. Hallam, 1971; Hallam \& Sellwood, 1976). This phase plays a major role in the tectonic structure throughout the northern North Atlantic continental margins.

\section{STRATIGRAPHY}

The basic stratigraphy of the Mesozoic deposits in the investigated area was well documented by Maync $(1947,1949)$, reviewed by Donovan (1957) and again on a broader level by Haller $(1970,1971)$. Although sediments at the Jurassic-Cretaceous boundary were slightly revised by Donovan (1964), these strata still represent a weak point in the stratigraphic scheme of earlier authors.

The existing stratigraphic nomenclature presents many problems. Vischer (1943) used mainly a 'facies-type' terminology comparable with modern lithostratigraphy, but at that time the biostratigraphic dating of the Volgian-Ryazanian-Valanginian rock units had not been completed by Maync, and as the two authors were not in correspondence during the Second World War, Vischer included Volgian as well as Ryazanian and Valanginian rocks in the Valanginian. Maync $(1947,1949)$ on the other hand, through the progress of his papers, changed from a lithostratigraphic or mixed litho/biostratigraphic to a strictly biostratigraphic classification. Unfortunately he perpetuated the formation type names such as 'Kuhn Beds', 'Yellow Series' or 'Banded Beds'. The syntectonic 'Rigi Series' was sometimes used by Maync as a formation name for all the very coarse clastic breccias and conglomerates of Volgian-Ryazanian age deposited along the Dombjerg Fault. However, by definition the term should be used in a mixed litho- and biostratigraphic sense to denote only the Volgian part of the syntectonic sediments (Maync, 1949).

I have therefore tried to present a complete lithostratigraphic scheme for the Volgian-Ryazanian-Valanginian sediments (fig. 1). The old names of Vischer (1943) and Maync $(1947,1949)$ have been used wherever possible, but redefined.

The biostratigraphic scheme is mainly based on my own collections and on comparisons with contemporaneous sequences in the Jameson Land region (Surlyk et al., 1973; Surlyk, 1973). Only few fossils of Volgian-Ryazanian-Valanginian age have been described and figured from the Wollaston Forland region. Spath $(1947,1952)$, Donovan (1964), and Jeletzky (1965) are practically the only sources of illustrations of fossils from these horizons. The stratigraphically most important fossils collected in 1974 are figured in plates $1-8$. The fauna is sparse and 
poorly preserved, and comparable faunas from this part of the sequence are known only from the Russian Platform, Siberia, Canada and eastern England, except for the Valanginian forms which have a somewhat wider distribution. The correlation potential of the fauna is thus not particularly good.

In the chronostratigraphic scheme the Volgian and Ryazanian are used as the Jurassic-Cretaceous boundary stages in the Boreal Realm. The base of the Berriasian still remains to be fixed and its boreal counterpart to be identified. Furthermore, there is no general agreement as to the position of the Jurassic-Cretaceous boundary in the Tethyan Realm. I will therefore follow Casey (1973) and place this boundary provisionally at the Volgian-Ryazanian boundary, i.e., at the base of the Chetaites sibirica Zone in Siberia or its British equivalent, the Runctonia runctoni Zone.

\section{Lithostratigraphy}

In the following section the succession of formal lithostratigraphic units (fig. 1) is discussed in ascending order. The lithology is only briefly noted as detailed descriptions are given in the sedimentological part of this paper. References to Maync's papers from 1947 and 1949, which contain a wealth of lithological information, are for practical purposes only given in a general way unless specific points are discussed. All numbered sections are figured in the appendix.

\section{Jameson Land Group}

The group was defined by Surlyk et al. (1973) with type area in Jameson Land. Surlyk (1977) extended the lithostratigraphic scheme currently in use for Jameson Land northwards to cover the areas treated in the present paper. Here the group includes the Vardekløft Formation (subdivided into the Pelion, Jakobsstigen, and Muslingebjerg Members), and the Bernbjerg Formation. The group is briefly mentioned here, since it forms the immediately underlying unit for the Wollaston Forland Group throughout the area.

\section{Thickness}

Up to $1600 \mathrm{~m}$.

\section{Boundaries}

Between $74^{\circ}$ and $75^{\circ} 30^{\prime} \mathrm{N}$ the group transgressively overlies either Caledonian basement or Upper Palaeozoic sediments. It is overlain with angular unconformity by the Wollaston Forland Group, black mudstones of Aptian-Albian age, or Tertiary plateau basalts. 


\section{Distribution}

In the northern area $\left(74^{\circ}-75^{\circ} 30^{\prime} \mathrm{N}\right)$ the sediments of the group outcrop in a small fault block on Clavering $\varnothing$. They cover much of central and eastern Wollaston Forland, but are covered by younger sediments or Tertiary basalts in western Wollaston Forland. The group covers most of south-west and south-east Kuhn $\varnothing$ and occurs in small down-faulted outliers on the east coast of Th. Thomsen Land, on south Hochstetter Forland and on Store Koldewey.

Geological age

Middle Jurassic (Bathonian) to Late Jurassic (Early Volgian).

\section{Wollaston Forland Group}

new group

Name

After the peninsula Wollaston Forland (fig. 2).

Type area

Wollaston Forland.

Thickness

Up to $3 \mathrm{~km}$.

\section{Dominant lithology}

The group commences with marine breccias, conglomerates, sandstones and mudstones of the Lindemans Bugt Formation. These are followed by thin marine conglomerates and sandstones and more dominant light grey mudstones with impure limestone bands of the Palnatokes Bjerg Formation.

\section{Boundaries}

The group rests on the Jameson Land Group or on peneplaned pre-Mesozoic basement, and is overlain by dark Aptian-Albian mudstones or Tertiary plateau basalts.

\section{Distribution}

The group occurs in north-west and north-east Wollaston Forland, in a small down-faulted block on north-east Clavering $\varnothing$, on east Kuhn $\varnothing$ and in a few outliers on western Kuhn $\varnothing$ and south-east Th. Thomsen Land. In other parts of East Greenland it occurs in Traill Ø (only represented by loose blocks of grey and red Valanginian mudstones), in eastern Hochstetter Forland and in eastern Store Koldewey.

\section{Geological age}

Late Jurassic (Middle Volgian) - late Valanginian. For further details see the discussion under the individual formations. 


\section{Subdivisions}

The group includes the Lindemans Bugt Formation, the Palnatokes Bjerg Formation, and the Volgian? and Valanginian sediments on Store Koldewey and Traill Ø (fig. 1).

\section{Lindemans Bugt Formation}

new formation

\section{History}

The formation name is adapted from Vischer's (1943, p. 88) Lindemans bugt Facies, which comprised the syntectonic conglomerates now known to be of Volgian-Ryazanian age. However, Vischer also included Valanginian sandstones and mudstones in his LindemansbugtFacies, partly under the misconception that all the rocks were contemporaneous and of Valanginian age (see Maync, 1949).

Mudstones, pebbly sandstones and thin conglomerates of Volgian age occurring in south-west Kuhn $\emptyset$ were called 'Schiefrige Bänderserie' or 'Banded Beds' by Maync $(1947,1949)$. In northern Wollaston Forland, contemporaneous or slightly younger breccias, conglomerates and sandstones were termed 'Rigi Series' exclusive of the Ryazanian part of the sequence which (in part) was called Lower Niesen Beds (Maync, 1949). The Valanginian part of this sequence is developed as mudstones with subordinate sandstones and thin conglomerates and was called Upper Niesen Beds. Donovan (1964) demonstrated that the prominent conglomerate beds on Rigi mountain could be followed eastwards to Niesen mountain. For this reason the terms 'Rigi Series' and 'Lower Niesen Beds' were considered synonyms and the term Niesen Beds was preferred owing to better exposure on Niesen. Some of the conglomerates can actually be traced as argued by Donovan but the lower beds wedge out to the east and pass rapidly into sandstones of Volgian age. New finds of Laugeites in these lower beds of conglomerate have shown that the lower part of the sequence exposed at Rigi is actually Volgian and as the Lower Niesen Beds by definition are Ryazanian the terms are not synonyms, although they were poorly defined and to some extent inconsistently used by Maync (1949).

The Lindemans Bugt Formation includes the Rigi Series and the Banded Beds of Maync (1949), the Lower Niesen Beds (Maync, 1949; Donovan, 1964), the Laugeites Beds (Donovan, 1964) and the pre-Valanginian part of the Lindemansbugt Facies of Vischer (1943).

Name

From Lindemans Bugt between Wollaston Forland and Kuhn Ø. The name was proposed by Vischer (1943) and is shown on his geological map (op. cit., plate 2).

\section{Type area}

North-west Wollaston Forland on the slopes of Niesen and Palnatokes Bjerg (fig. 3) where many good sections are exposed.

\section{Reference sections}

Section 20, Niesen; section 15, Niesen; section 22, Niesen; section 24, Niesen; section 34; section 49 , Palnatokes Bjerg; section 50, Palnatokes Bjerg. Appendix.

\section{Thickness}

In the deepest part of the Young Sund - Fligelys Fjord trough where it is developed in its maximum thickness it is judged to be about $2 \mathrm{~km}$ although the base of the formation is not exposed. It wedges out rapidly to the east. 
Lithology

Huge breccias composed of angular blocks from the Caledonian basement occur to the west along the fault scarp of the Dombjerg-Thomsen Land Fault. The blocks occasionally reach a size of $20 \mathrm{~m}$ but blocks of $0.5-2 \mathrm{~m}$ length are more common. The breccias interfinger with prominent conglomerates composed of $10-50 \mathrm{~cm}$ boulders in a matrix of coarse sand and gravel. The breccias and conglomerates rapidly wedge out to the east and pass into medium to coarse-grained sandstone and finally into dark inter-laminated mudstone and fine sandstone. In spite of the coarse grain size the sequence contains marine fossils in all lithologies. Buchia is very abundant and Laugeites, pavlovid ammonites and belemnites also occur.

\section{Boundaries}

The lower boundary is exposed in the following areas: (1) south-west Kuhn $\varnothing$ where the formation rests unconformably on black mudstones of the Upper Jurassic Bernbjerg Formation; (2) in western Wollaston Forland and eastern Clavering $\varnothing$ where it unconformably overlies the Middle Jurassic Pelion Member of the Vardekløft Formation or the Bernbjerg Formation; (3) along the western margin of the sedimentary basin in Wollaston Forland and Th. Thomsen Land where it rests directly on Caledonian basement along the Dombjerg-Thomsen Land Fault.

\section{Distribution}

The Lindemans Bugt Formation outcrops on north-east Clavering $\varnothing$, north-west Wollaston Forland, eastern Th. Thomsen Land and south-west Kuhn $\varnothing$.

\section{Geological age}

The lower member contains rich ammonite faunas of the Laugeites groenlandicus Zone (late Middle Volgian), whereas the top part of the formation contains ammonites of the Surites tzikwinianus Zone (mid Upper Ryazanian).

\section{Laugeites Ravine Member new member}

\section{History}

The member is equivalent to the 'Schiefrige Bänderserie' or 'Banded Beds' of Maync (1947, 1949), but are conceptually different from the biostratigraphically defined Laugeites Beds of Donovan (1964).

Name

After the small stream creek Laugeites Ravine at the south-west coast of Kuhn $\varnothing$ (named by Donovan, 1964).

Type locality

Laugeites Ravine, Kuhn $\varnothing$. The section is now relatively badly exposed. A composite section is published by Maync (1947, p. 28-36 and 1949, pl. 2) and a sketch map is given by 
Donovan (1964, fig. 2). Maync's interpretation of the succession must be looked upon with some scepticism (see also Donovan, 1964, p. 12-13), but Donovan's map gives an accurate description of the locality.

\section{Reference sections}

Sections 5 and 7, south and north respectively of the mouth of Laugeites Ravine; section $20^{1}$, Niesen. Appendix.

\section{Thickness}

The lower boundary is not exposed in the same section as the upper boundary, but the thickness is estimated as at least $80 \mathrm{~m}$.

\section{Lithology}

Units of laminated mudstones and inter-laminated mudstones and fine sandstones alternate with subordinate, thick, pebbly sandstones and fine conglomerates. The thicker sandstones are deposited in small channels 2-5 m wide. They are well graded and commence with a conglomerate composed of pebbles, small wood fragments, and intraformational mudstone and fine sandstone clasts. Individual channels cut each other and their axes have a uniform east-west direction. The fine-grained sandstones show thin mud flasers, whilst the inter-laminated mudstone and sandstone sometimes show a wavy or irregular bedding The least sandy horizons are mainly well laminated. Buchia and ammonites are often common in the pebbly sandstones.

\section{Boundaries}

The Laugeites Ravine Member rests unconformably on older Mesozoic rocks. The lower boundary of the member is often difficult to locate where the mudstones of the member overlie the mudstones of the Bernbjerg Formation, and this is especially true where palaeontological evidence is lacking. The Bernbjerg mudstones are, however, more evenly laminated, finer grained and contain very characteristic, large, yellowish, calcite-cemented concretions. The upper boundary is placed where the dominantly muddy sediments of the member are overlain by breccias, coarse conglomerates and sandstones of the Rigi Member.

\section{Distribution}

The member occurs along the eastern margin of the Lindemans Bugt Formation in Wollaston Forland and in Kuhn Ø. At present it is only well known from section $20^{1}$ at Niesen (Appendix) and from the type locality.

\section{Geological age}

Middle - Late Volgian. Pavlovid ammonites and several species of Laugeites occur commonly in the lower levels. At the top of the type section Late Volgian Subcraspedites occur together with a species of Laugeites. At the top of the member in section $20^{1}$ (Niesen), an assemblage of Epilaugeites vogulicus and Buchia indicates a late Middle Volgian age. 


\author{
Rigi Member \\ new member
}

History

Maync (1949) restricted the name 'Rigi Series' to cover only the Volgian part of the syntectonic facies. Here the name is formalized as a member which designates all Volgian-Ryazanian coarse clastic sediments deposited near the Dombjerg Fault scarp. The member thus includes the Rigi Series of Maync (1949), the pre-Valanginian part of the Lindemansbugt Facies of Vischer (1943) and the coarse clastic parts of Maync's Lower Niesen Beds.

Name

From the mountain Rigi in north-west Wollaston Forland (fig. 2). The name was given by Maync and is shown as point $484 \mathrm{~m}$ by Vischer (1943, plate 1); the position is also shown by Maync (1947, fig. 15; 1949, fig. 9) and by Donovan (1964, fig. 1).

Type area

The north-west slopes of Palnatokes Bjerg (where Rigi forms a small isolated summit) and the north slopes of Niesen. Rigi itself is totally unexposed and cannot serve as the type locality.

\title{
Reference sections
}

Section 15, Niesen; section 22, Niesen; sections 30-33; sections 49-50, Palnatokes Bjerg. Appendix.

\section{Thickness}

The lower boundary is not exposed in sections with maximum thickness, but this is estimated as $2 \mathrm{~km}$.

\section{Lithology}

To the west the member comprises breccias, conglomerates, and coarse sandstones. In an eastwards direction the conglomerates wedge out and grade into coarse and medium sandstones. The breccias are composed of angular, densely packed boulders of quartzite, gneiss, mica schist, amphibolite, dolerite, and other rock types derived from the Caledonian basement.

The conglomerates may be clast or matrix supported and the clasts are often strongly imbricated indicating a west to east transport direction. The boulders are normally well rounded quartzites with subordinate gneisses and small amounts of other rock types. The matrix is normally coarse pebbly sandstone.

The sandstones are friable and badly sorted but often well graded as are the conglomerates. Sedimentary structures are rare, but the conglomerates may have erosive or even channelled bases, whereas the sandstones either show vague horizontal lamination or fill relatively wide channels. Cross-bedding is extremely rare.

Buchia is relatively common in all rock types except for the breccias, where only a few have been noted together with rare belemnites. Ammonites occur scattered throughout the member. 
Kuhn Ø

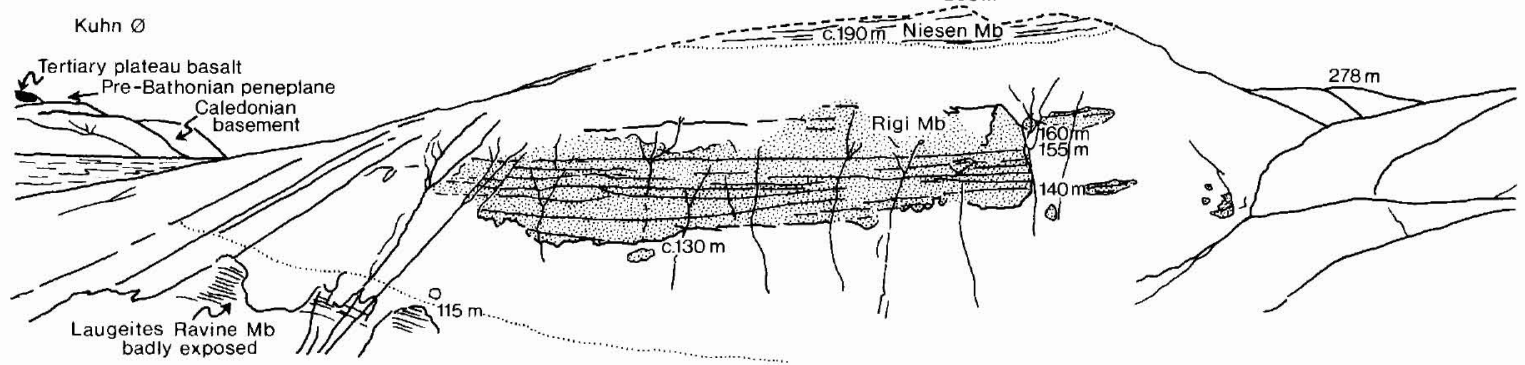
badly exposed

Fig. 5. Section 20 Niesen, north Wollaston Forland. At the base and up to $115 \mathrm{~m}$ Laugeites Ravine Member (Middle Volgian), overlain with slight angular unconformity by Rigi Member (115 - somewhere between 160 and $190 \mathrm{~m}$ ) which again is overlain by Niesen Member (Upper Volgian-Ryazanian). The Volgian-Ryazanian boundary is slightly above the base of the Niesen Member. The Rigi Member is deposited in broad shallow channels mainly of the midfan association. In the background to the north is seen the south coast of Kuhn $\varnothing$. The south-westwards tilted pre-Jurassic peneplaned surface of the Caledonian basement is overlain by a mid-late Jurassic sequence with is overlain with strong angular unconformity by horizontal Tertiary plateau basalts.

\section{Boundaries}

The lower boundary is placed where the coarse clastic sediments overlie either the dark mudstones and sandstones of the Laugeites Ravine Member or where this is absent, the Pelion sandstones or Bernbjerg mudstones with angular unconformity. In section $20^{2}$, Niesen (Appendix), the Rigi Member rests on the Laugeites Ravine Member with angular unconformity (fig. 5).

\section{Distribution}

The Rigi Member outcrops in north-west Clavering $\varnothing$, north-west Wollaston Forland, south-east and eastern Th. Thomsen Land and on west Kuhn $\varnothing$ ('Konglomeratrücken' of Maync, 1947, fig. 1).

\section{Geological age}

The basal part of the member contains Buchia and Laugeites of Middle Volgian age, whereas the top beds contain ammonites of the Late Ryazanian Surites (Caseyiceras) analogus Zone. The member thus spans the Jurassic-Cretaceous boundary.

\section{Niesen Member new member}

\section{History}

The name Niesen Member is adapted from the Niesen Beds of Maync (1949). The member corresponds to the fine-grained part of the Lower Niesen Beds of Maync (1949) although probably of wider geographical extent, and likewise to the fine-grained pre-Valanginian part of Vischer's (1943) Lindemansbugt Facies. 
Name

From the mountain Niesen in northern Wollaston Forland (fig. 3). The name was introduced by Maync (1949, fig. 9).

Type section

Section $20^{3}$, Niesen (Appendix).

Thickness

About $200 \mathrm{~m}$. The member disappears rapidly to the west where it interfingers with the Rigi Member.

Lithology

The member is dominated by dark mudstones, inter-laminated mudstones and fine sandstones, and thin beds of fine-grained sandstone. Scattered calcareous concretions and nodules, and calcite cemented beds occur. The concretions weather in reddish or pale yellow colours.

Buchia, ammonites, belemnites and plant fragments are locally abundant in cemented horizons.

Boundaries

The lower boundary is placed where the dark mudstones of the member overlie conglomerates and coarse-grained sandstones of the Rigi Member. To the west Niesen Member interfingers with the Rigi Member and wedges out rapidly.

The upper boundary is often transitional. It is placed where the light grey mudstones with abundant limestone horizons and concretions, and coarse clastic sediments of the Palnatokes Bjerg Formation commence.

\section{Distribution}

The member is only found in a narrow N-S strip in western Wollaston Forland along the eastern margin of the Lindemans Bugt Formation. The lithology is almost identical to the lower part of the contemporaneous Crinoid Bjerg Member in southern Jameson Land (Surlyk, 1973; Surlyk et al., 1973).

\section{Geological age}

The lower part of the member contains the ammonite 'Virgatosphinctes' tenuicostatus Shulgina followed by Praetollia maynci Spath, whereas the upper part contains Surites tzikwinianus (Bogoslovsky). This indicates a Late Volgian to Late Ryazanian Age.

\section{Palnatokes Bjerg Formation}

new formation

\section{History}

The formation includes the Upper Niesen Beds, the Albrechts Bugt Facies, the Young Sund Facies, the Falskebugt Beds, and the Rødryggen Beds of Maync (1949). The Albrechts Bugt Facies, parts of the Kuhnpas Facies and the upper part of the Lindemansbugt Facies of Vischer (1943) are also included. 
Name

From the basalt covered mountain Palnatokes Bjerg in north-west Wollaston Forland (fig. 3).

Type area

The upper slopes of the mountains Palnatokes Bjerg and Niesen.

Reference sections

Section 10, Perisphinctes Ravine, eastern Kuhn Ø; section 13, eastern Kuhn Ø; section 18, Niesen; section 53-54, Rødryggen, all in Wollaston Forland. Appendix.

\section{Thickness}

The maximum thickness is estimated at about $600 \mathrm{~m}$ but the formation wedges out to the east where the thickness is only $25-30 \mathrm{~m}$.

\section{Lithology}

Coarse conglomerates with occasional breccia beds; pebbly sandstones; coarse medium and fine-grained sandstones; inter-laminated mudstones and fine sandstones; dark mudstones and light mudstones with abundant calcareous concretions and layers; dark-red and yellow mudstones. An isolated turbidite sequence from eastern Kuhn $\varnothing$ has been described by Surlyk \& Clemmensen (1975a). The mudstones are dominant whereas the sandstones and especially the conglomerates form a minor part of the section. Trace fossils, notably Zoophycos, occur in abundance in the mudstones and fine sandstones.

The concretions in the fine-grained layers weather in very characteristic dark-red, pink or white shades. The sandstones often weather out in perfectly ball-shaped concretions often more than one metre in diameter (fig. 6).

Buchia and belemnites are locally very common, but ammonites are relatively rare.

\section{Boundaries}

The lower boundary of the Palnatokes Bjerg Formation is placed where the light-grey mudstones with abundant concretions and thin horizons of fine-grained sandstones overlie the dominantly coarse Lindemans Bugt Formation. Where they rest on the more fine-grained Niesen Member they have a lighter colour and always contain more concretionary horizons, although the boundary is of a transitional nature. Where the coarse grained members overlie the coarse Rigi Member of the Lindemans Bugt Formation it contains abundant reworked slabs of fine sandstone and especially light mudstone and concretions from the almost contemporaneous Albrechts Bugt Member.

In contrast, the Rigi conglomerates are solely composed of Caledonian pebbles and boulders with practically no reworked sediments.

The upper boundary is placed at the base of dark Aptian-Albian mudstones with intercalated mudstones. This contact is an erosional or angular unconformity.

\section{Distribution}

The main occurrence of the formation is in western, central and north-east Wollaston Forland and south-east Kuhn $\emptyset$. Isolated outliers occur in north-east Clavering $\varnothing$, on Traill $\varnothing$, on eastern Hochstetter Forland, and on Store Koldewey. 


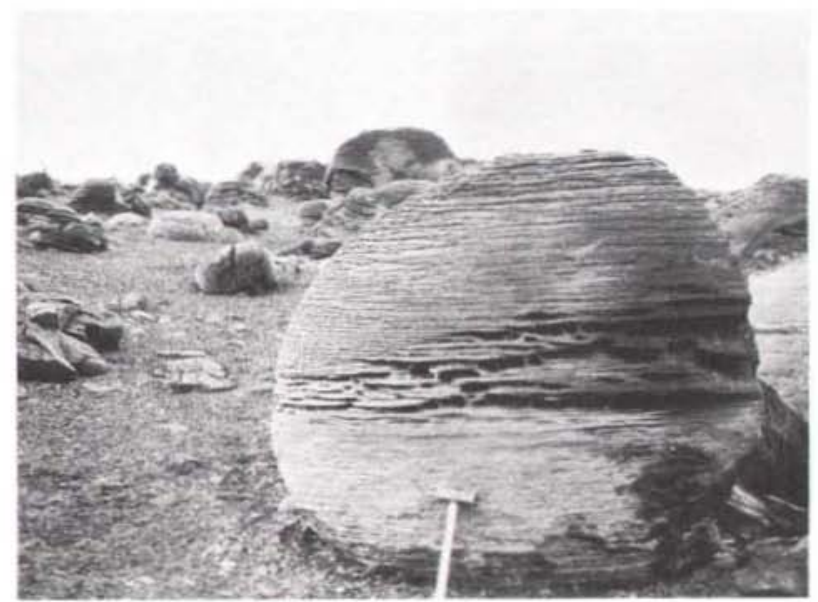

Fig. 6. Spherical weathering of thick, even parallel laminated turbidite sandstone of the Young Sund Member. Niesen, northern Wollaston Forland. About $600 \mathrm{~m}$ altitude.

\section{Geological age}

The fauna from the Wollaston Forland region has been listed by Maync (1949), and a few Buchia have been figured in various papers. A rich ammonite fauna was described, however, from exactly the same facies types on Traill $\varnothing$ by Donovan (1953). To a large extent the Wollaston Forland ammonites are conspecific with the Traill $\varnothing$ fauna, which seems to indicate the presence of late Lower and Upper Valanginian (Donovan, 1953, 1957; Jeletz$\mathrm{ky}, 1965$ ). The present material indicates a latest Ryazanian (Bojarkia mesezhnikovi Zone)Valanginian (Buchia crassicollis Zone) age.

\section{Young Sund Member \\ new member}

History

The member corresponds more or less to the Young Sund Facies of Maync (1949), although Maync apparently restricted the Young Sund Facies to comprise only the coarsest part of the sequence.

Name

After Young Sund - the sound between south-west Wollaston Forland and Clavering $\varnothing$ (fig. 2).

Type locality

Stratumbjerg on the southern side of Cardiocerasdal (section 37, Appendix; fig. 7).

\section{Thickness}

Less than $50 \mathrm{~m}$ at the type locality. In the area around Palnatokes Bjerg and Niesen (fig. 3) the member interfingers as wedges in the Albrechts Bugt Member through a thickness of about $250-300 \mathrm{~m}$. The original maximum thickness is estimated at about $600 \mathrm{~m}$. 


\section{Lithology}

Coarse conglomerates with subordinate breccias, interfingering with coarse and medium-grained sandstones containing thin pebble beds (often pink feldspar clasts). The clasts in the conglomerates are normally well rounded quartzites, gneisses and amphibolites often with a thin ferruginous crust. Large angular or rounded blocks of the underlying Jurassic sandstones of the Pelion Member also occur abundantly. A characteristic and diagnostic feature of the member is the occurrence of reworked pieces of more or less contemporaneous light-grey mudstones together with calcareous concretions of the Albrechts Bugt Member. These concretions commonly contain well preserved Valanginian Buchia. Water-worn belemnites may occur in both conglomerates and sandstones.

\section{Boundaries}

The member overlies Pelion sandstones and Bernbjerg mudstones with angular unconformity in south-west Wollaston Forland and Clavering $\varnothing$. Where it overlies the coarse clastic Rigi Member of the Lindemans Bugt Formation it can be distinguished by its large content of reworked sediments - notably light mudstones and concretions of the penecontemporaneous Albrechts Bugt Member. The upper boundary is placed where the member is overlain unconformably by dark mudstones witch intercalated sandstones of Aptian-Albian age. The contact is usually an erosional or angular unconformity. The member interfingers laterally to the east with the Albrechts Bugt Member.

\section{Distribution}

The Young Sund Member crops out in a north-south belt parallel to the Clavering-Dombjerg Fault in north-east Clavering $\varnothing$ and western Wollaston Forland. In addition it is found on Store Koldewey immediately east of a fault scarp (Ravn, 1911; Maync, 1949).

\section{Geological age}

The member interfingers with the Valanginian Albrechts Bugt Member and contains reworked fossils of this member and is consequently also of latest Ryazanian-Valanginian age.

\section{Falskebugt Member \\ new member}

History

The member corresponds to the Falskebugt Beds of Maync (1949).

\section{Name}

From the bay Falskebugt in eastern Wollaston Forland (plate 9).

Type locality

Western slope of Falkebjerg north of Falskebugt, eastern Wollaston Forland (fig. 3). Owing to tectonic disturbances and lack of good continuous exposures no section could be measured, but the different rock-types are well exposed. 


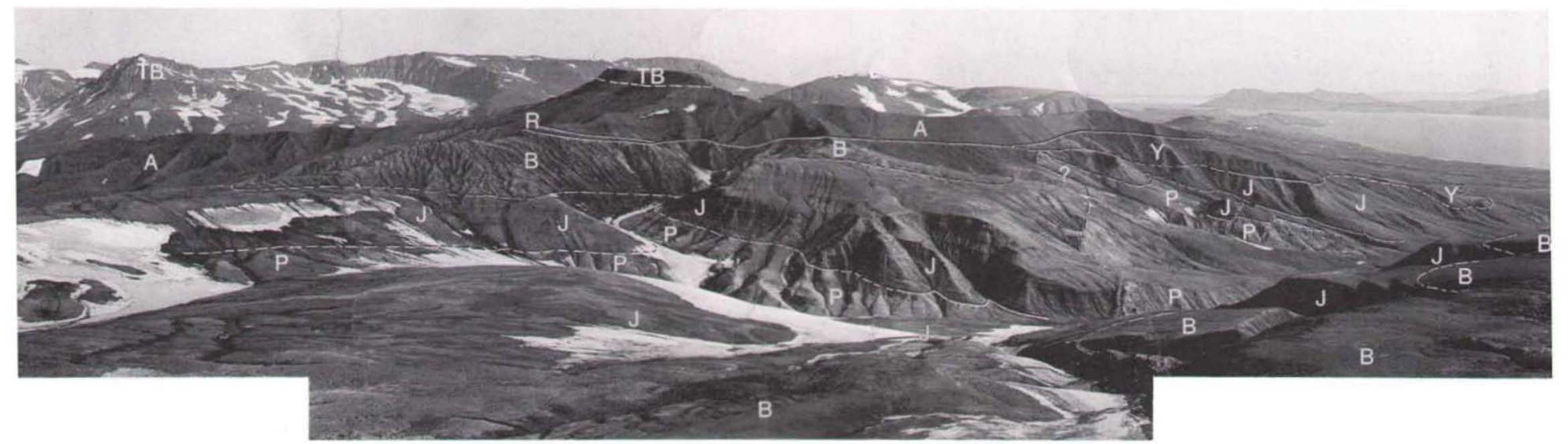

Fig. 7. South-eastern side of Cardiocerasdal, Stratumbjerg, with faulted and westwards tilted sediments of the Jameson Land Group unconformably overlain by Valanginian conglomerates and Aptian-Albian mudstones. P: Pelion Member; J: Jakobsstigen Member; B: Bernbjerg Formation- Y: Young Sund Member; R: Rødryggen Member; A: Aptian-Albian; TB: Tertiary plateau basalts. 


\section{Thickness}

Estimated at about 40-50 m (Maync, 1949).

\section{Lithology}

Conglomerates with pinkish matrix and coarse sandstones which may contain reworked Albrechts Bugt sediments. The lithology is very similar to the Young Sund Member, but the Falskebugt Member, however, forms an isolated body lying on the western flank of the Hühnerbjerg Block (fig. 3), and is therefore designed as a separate member.

\section{Boundaries}

The member rests on Caledonian basement, interfingers to the west with Albrechts Bugt mudstones and is overlain with angular unconformity by dark Aptian-Albian mudstones.

\section{Distribution}

Occurs only on the western flank (the dip-slope) of the Hühnerbjerg Block.

Geological age

Middle-Late Valanginian.

History

\section{Albrechts Bugt Member}

new member

The member includes the more restricted Albrechts Bugt Facies of Maync (1949), the Kuhnpas Facies of Vischer (1943) and the Albrechts Bugt Facies excluding the Rødryggen Member (as here defined) of Vischer (1943). It also includes to a large extent the Upper Niesen Beds of Maync (1949).

Name

After the bay Albrechts Bugt in northern Wollaston Forland. The name was introduced by Maync (1949).

Type locality

Rødryggen, north-central Wollaston Forland (plate 9).

\section{Reference sections}

Section 10, Perisphinctes Ravine and section 13, eastern Kuhn $\varnothing$; section 18, Niesen and sections 53-54, Rødryggen, Wollaston Forland. Appendix.

\section{Thickness}

About $300 \mathrm{~m}$ at Niesen (section 18) where, however, it interfingers with the most fine-grained parts of the Young Sund Member. To the east the member rapidly wedges out to about $30 \mathrm{~m}$.

\section{Lithology}

Fine, sandy, light-grey to yellowish mudstones with abundant calcareous concretions, nodules and layers, which to the west grade into darker mudstones intercalated with 
fine-grained sandstones. Maync (1949) consistently described the sediments as marl or limestones and stressed that the Valanginian represents the first period since the Permian where limestones were deposited in abundance in East Greenland. However, a series of chemical analyses show that the so-called marls do not contain calcium carbonate at all or only as traces directly related to the presence of skeletal grains in the sample. The 'limestones', that is, the calcareous concretionary nodules and layers contain between 55-62 per cent $\mathrm{CaCO}_{3}$. The mudstones are often strongly bioturbated and contain well preserved trace fossils, notably Zoophycos, in abundance.

\section{Boundaries}

The lower boundary is placed where the light mudstones transitionally overlie darker Niesen Member mudstones with much fewer concretions, or the coarse clastic sediments of the Rigi Member.

In southern and eastern Wollaston Forland and eastern Kuhn $\varnothing$ it rests with angular unconformity on the black Upper Jurassic Bernbjerg mudstones. It interfingers with the Young Sund and the Falskebugt conglomerates and sandstones to the west and east respectively. It is overlain by red mudstones of the Rødryggen Member.This boundary is often of a transitional nature and is placed at the first massive, dark-red layer of mudstone. Where the Rødryggen is removed by pre-Aptian erosion the Albrechts Bugt is overlain with erosional or angular unconformity by dark Aptian-Albian mudstones with intercalated sandstone horizons.

\section{Distribution}

The member crops out in western, central and south-west Wollaston Forland, on eastern Kuhn $\varnothing$, on eastern Hochstetter Forland and far to the south on Traill $\varnothing$.

Geological age

Latest Ryazanian-Valanginian.

\section{Rødryggen Member}

new member

\section{History}

Identical to the Rødryggen Beds of Maync (1949), but included in the Albrechts Bugt Facies of Vischer (1943).

Name

After the low ridge Rødryggen in central Wollaston Forland.

Type section

Section 54, Rødryggen, central Wollaston Forland (Appendix).

Reference sections

Section 53, Rødryggen, central Wollaston Forland, and the section on the north ridge of Stratumbjerg, south-west Wollaston Forland (fig. 7). 
Thickness

Maximum $15 \mathrm{~m}$.

Lithology

Red, massive or horizontally laminated, sometimes fine sandy hematitic mudstones with intercalated fine sandy yellow mudstones. The soft mudstones are non-calcareous whereas the lithified nodules or layers have a $\mathrm{CaCO}_{3}$ content of $50-60$ per cent. The content of shell fragments, largely in the form of inoceramid prisms, can be very large. The sediments are often brecciated or contain clasts of grey, greenish or yellow mudstone.

The trace fossil Zoophycos occurs in abundance. Buchia, ammonites and belemnites are commonly abundant, whereas whole inoceramids and brachiopods occur more rarely.

\section{Boundaries}

Rests with transitional contact on the light grey Albrechts Bugt mudstones or in rare cases with angular unconformity on black Upper Jurassic Bernbjerg mudstones. It is overlain with angular or erosional unconformity by dark Aptian-Albian mudstones and thin sandstones.

Distribution

Crops out in Stratumbjerg south-west Wollaston Forland, central Wollaston Forland, eastern Kuhn $\varnothing$, eastern Hochstetter Forland, and further south on Traill $\varnothing$.

Geological age

Middle to Late Valanginian.

\section{Biostratigraphy}

All formations and members of the Wollaston Forland Group contain marine fossils. The most common forms are different species of the bivalve Buchia, which often occur in great abundances in most facies, whereas ammonites have a much more scattered distribution. Buchia generally shows fairly good shell preservation, but is often worn or crushed. Ammonites are in most cases preserved as casts or internal moulds often composed of very coarse-grained sediment.

The biostratigraphic scheme is based mainly on ammonites supported by Buchia, and although the record is rather fragmentary, the problem of correlating a Buchia zonation established in one region with an ammonite zonation of another region is hereby to some extent avoided (see Jeletzky, 1973; Surlyk, 1973; Casey \& Rawson, 1973). Section 20 (fig. 5) on the north-western slope of Niesen, north Wollaston Forland is used as a 'standard section' for the biostratigraphic zonation supported by material collected in other sections. It contains all members (except the Valanginian Rødryggen Member) of the Wollaston Forland Group developed in relatively fine-grained facies types and with a position fairly close to the axis of the depositional trough, where the greatest thicknesses are encountered. The section 
contains one minor angular unconformity between the Laugeites Ravine Member and the Rigi Member (fig. 5). The lowest $c .200 \mathrm{~m}$ of the section belong to the Volgian Stage, the following $c .200 \mathrm{~m}$ to the Ryazanian Stage, and the highest $c$. $300 \mathrm{~m}$ to the Valanginian Stage. The section thus spans the Jurassic-Cretaceous boundary, irrespective of whether this boundary is placed at the Volgian-Ryazanian boundary, or at the Middle-Upper Volgian boundary which is thought to correlate with the Tithonian-Berriasian boundary (Casey, 1973). The section seems to contain an almost unbroken ammonite succession across the boundary which can be compared to the successions known from the Russian Platform, Siberia (e.g. Casey et al., 1977) and eastern England (Casey, 1973) (table 1). The section is well exposed and it must be remembered that the material from the section was collected within two days where the main purpose was to make sedimentological studies. More detailed collecting will therefore undoubtedly result in a more refined zonation. The section thus classifies as a standard reference section for the Jurassic-Cretaceous boundary in the Boreal Realm as also suggested by earlier authors (e.g. Maync, 1947, 1949; Spath, 1952). It is much more complete than suggested by Donovan (1964) who claimed that there was no positive evidence for the whole of the Upper Volgian. The presence of the Upper Volgian is now documented from both the Niesen section and from Jameson Land (Surlyk, 1973).

The purpose of the biostratigraphic zonation of the Wollaston Forland Group is threefold: firstly, to provide an internal reference system within the sedimentary prism; secondly, to correlate the important tectonic movements at the Jurassic-Cretaceous boundary within East Greenland and the northern North Atlantic; and thirdly, purely biostratigraphical, in refining the zonation and in providing a better interregional correlation of Volgian/Tithonian and Berriasian/Ryazanian strata.

The zonations recently established in eastern England (Casey, 1973), the Russian Platform, the pre-Polar Urals and Siberia (e.g. Casey et al., 1977) have been particularly useful for comparisons (table 1 ).

\section{Zonation}

Laugeites groenlandicus Zone (plate 1; plate 2 figs 1-3)

The zone is characterized by its index fossils and by the presence of Laugeites parvus Donovan, Laugeites intermedius Donovan, Pavlovia (Pallasiceras) cf. rotundiformis Spath and other pavlovid ammonites with sharp usually bifurcating ribs. Previously Laugeites groenlandicus Spath was known in Greenland with only two specimens from Milne Land (Spath, 1936) and one possible fragment from Kuhn $\varnothing$ (Donovan, 1964).

In the Wollaston Forland area L. parvus is by far the most common ammonite in the zone. Only one specimen of L. groenlandicus (plate 1, fig. 1) was found at $50 \mathrm{~m}$ 
Table 1. Correlation of the Jurassic-Cretaceous boundary zonations of East Greenland, eastern England, the Russian Platform, northern Siberia and northern Canada

\begin{tabular}{|c|c|c|c|c|c|c|c|c|c|c|c|}
\hline$\frac{\infty}{0}$ & & 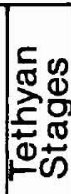 & 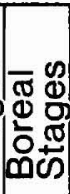 & $\begin{array}{l}0 \\
\frac{\Phi}{8} \\
\frac{0}{\infty} \\
\frac{0}{7} \\
\text { ம }\end{array}$ & $\begin{array}{l}\text { Norfolk } \\
\text { E. England }\end{array}$ & $\begin{array}{l}\text { Russian } \\
\text { Platform }\end{array}$ & $\begin{array}{l}\text { Subpolar } \\
\text { Urals }\end{array}$ & $\begin{array}{l}\text { Northern } \\
\text { Siberia }\end{array}$ & Canada & \multicolumn{2}{|c|}{$\begin{array}{l}\text { Wollaston Forland } \\
\qquad \begin{array}{l}\text { Observed } \\
\text { Zones }\end{array} \\
\begin{array}{l}\text { range of } \\
\text { zonal indices }\end{array}\end{array}$} \\
\hline \multirow{14}{*}{$\begin{array}{l}0 \\
0 \\
0 \\
0 \\
\frac{1}{5} \\
\frac{\pi}{0} \\
\frac{\pi}{0}\end{array}$} & \multirow{10}{*}{$\sum_{0}^{1}$} & \multirow{5}{*}{$\begin{array}{l}\frac{c}{\sigma} \\
\frac{.0}{\sigma} \\
\frac{\sigma}{\sigma} \\
\frac{\sigma}{\sigma}\end{array}$} & \multirow{5}{*}{$\begin{array}{l}\frac{\Gamma}{\sigma} \\
\frac{.}{\sigma} \\
\frac{\sigma}{\sigma} \\
\frac{\sigma}{\sigma} \\
>\end{array}$} & \multirow{5}{*}{ 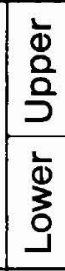 } & \multirow{2}{*}{$\begin{array}{l}\text { Dichotomites } \\
\text { spp. }\end{array}$} & \multirow{2}{*}{$\begin{array}{l}\text { Homolsomites } \\
\text { petschorensis }\end{array}$} & \multirow{2}{*}{$\begin{array}{l}\text { Dichotomites } \\
\text { ramulosus }\end{array}$} & $\begin{array}{l}\text { Homolsomites } \\
\text { bojarkensis }\end{array}$ & \multirow{2}{*}{$\begin{array}{l}\begin{array}{l}\text { Buchia aff. } \\
\text { inflata } \\
\text { crassicol } \\
\text { fis }\end{array} \\
\text { B. sublaevis }\end{array}$} & $\begin{array}{l}1 \text { Buchia } \\
\text { crassicollis }\end{array}$ & \multirow{5}{*}{ 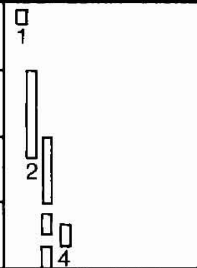 } \\
\hline & & & & & & & & $\begin{array}{l}\text { Prodichotomites } \\
\text { spp. }\end{array}$ & & 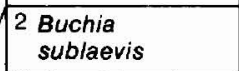 & \\
\hline & & & & & \multirow{2}{*}{$\begin{array}{l}\text { Polyptychites } \\
\text { spp. }\end{array}$} & $\begin{array}{l}\text { P. polyptychus } \\
\text { P. michalskii }\end{array}$ & & \begin{tabular}{|l|l|} 
Pstub - & Pe keyserling \\
endorffi & P. michalskit \\
\end{tabular} & $\begin{array}{l}\text { P. sphaeroidalis } \\
p_{\text {P. keyserlingi }} \\
\text { P. stubendorffi } \\
\text { Pey- }\end{array}$ & $\begin{array}{l}3 \text { Buchia } \\
\text { keyserlingi }\end{array}$ & \\
\hline & & & & & & T. hoplitoides & \multirow{2}{*}{$\begin{array}{l}\text { P. michalskii } \\
\text { Temnoptychites } \\
\text { insolutus }\end{array}$} & T. syzranicus & \multirow{2}{*}{\begin{tabular}{l|l} 
P. stubendorfi & key- \\
Th.ellesmerense ser- \\
T. kemperi \\
T. troeiseni & lingi \\
\end{tabular}} & \multirow{2}{*}{\begin{tabular}{|c|} 
Tollia \\
tolli
\end{tabular}} & \\
\hline & & & & & Pseudogarnieria & P. undulatoplicatilis & & N. klimovskiensis & & & \\
\hline & & & & & $\begin{array}{l}\text { Peregrinoceras } \\
\text { albidum }\end{array}$ & $\begin{array}{l}\text { Peregrinoceras } \\
\text { aff. albidum }\end{array}$ & Bojarkia & Bojarkia & Buchia n.sp. aff. & $\begin{array}{l}5 \text { Bojarkia } \\
\text { mesezhnikovi }\end{array}$ & $3 \prod_{5}$ \\
\hline & & & $\frac{c}{\delta}$ & $\begin{array}{l}\bar{\Phi} \\
\text { 응 }\end{array}$ & $\begin{array}{l}\text { Bojarkia } \\
\text { stenomphala }\end{array}$ & \begin{tabular}{|l} 
Surites \\
tzikwinianus
\end{tabular} & payeri & mesezhnikovi & $\begin{array}{l}\text { Tollia cf. } \\
\text { payeri }\end{array}$ & $\begin{array}{l}\text { Surites } \\
\text { tzikwinianus }\end{array}$ & $\frac{\square}{6}$ \\
\hline & & & 颂 & $\supset$ & $\begin{array}{l}\text { Lynnia } \\
\text { icenii }\end{array}$ & \begin{tabular}{|l|} 
Euthymiceras \\
transfigurabilis
\end{tabular} & $\begin{array}{l}\text { Surites (Caseyice - } \\
\text { ras) analogus }\end{array}$ & $\begin{array}{l}\text { Surites (Caseyice- } \\
\text { ras) analogus }\end{array}$ & $\begin{array}{l}\text { Buchia } \\
\text { uncitoides }\end{array}$ & $\begin{array}{l}7 \text { Surites (Caseyice } \\
\text { ras) analogus }\end{array}$ & $\frac{\square}{7}$ \\
\hline & & . & $\overbrace{0}^{\infty}$ & $\stackrel{1}{\$}$ & $\begin{array}{l}\text { Hectoroceras } \\
\text { kochi }\end{array}$ & $\begin{array}{l}\text { Hectoroceras } \\
\text { kochi }\end{array}$ & $\begin{array}{l}\text { Hectoroceras } \\
\text { kochi }\end{array}$ & $\begin{array}{l}\text { Hectoroceras } \\
\text { kochi }\end{array}$ & Buchia & \begin{tabular}{|l|}
8 Hectoroceras \\
kochi
\end{tabular} & D \\
\hline & & ? & & ó & $\begin{array}{l}\text { Praetollia (Runc- } \\
\text { tonia) runctoni }\end{array}$ & \begin{tabular}{|l|}
$\begin{array}{l}\text { Riasanites \& } \\
\text { Garniericeras }\end{array}$ \\
\end{tabular} & $\begin{array}{l}\text { Chetaites } \\
\text { sibiricus }\end{array}$ & $\begin{array}{l}\text { Chetaites } \\
\text { sibiricus }\end{array}$ & & $\begin{array}{c}9 \text { Praetollia } \\
\text { maynci }\end{array}$ & 8 \\
\hline & & ఏ్ & & & $\begin{array}{l}\text { Subcr. (Volgidis - } \\
\text { cus) lamplughi }\end{array}$ & Craspedites & (Volgidiscus) & $\begin{array}{l}\text { Chetaites } \\
\text { chetae }\end{array}$ & $\begin{array}{l}\text { B.unschensis } \\
\text { B.terebratuloides }\end{array}$ & 10 'Virgatosphinctes' & $\begin{array}{r}94 \\
\square\end{array}$ \\
\hline & & & & $\overline{\mathbf{Q}}$ & Subcraspedites & nodiger & Crasp. taimyrense & Crasp. taimyrense & C. canadensis & tenuicostatus & 0 \\
\hline & & & & 은 & (S.) preplicomphalus & s Crasp. subditus & Crasp. subditus & Crasp C. originale & & beds & $\square$ \\
\hline & & & $\cdot \frac{\sqrt{\sigma}}{\sigma}$ & $\supset$ & $\begin{array}{l}\text { Subcrasp. (Swinn.) } \\
\text { primitivus }\end{array}$ & $\begin{array}{l}\text { Kachpurites } \\
\text { fulgens }\end{array}$ & $\begin{array}{l}\text { Kachourites } \\
\text { fulgens }\end{array}$ & \begin{tabular}{ll}
$\begin{array}{l}\text { oken- } \\
\text { sis }\end{array}$ & C. okensis \\
\cline { 2 - 2 } & 'Virg.exoticus \\
\end{tabular} & fischeriana & & $\underset{10}{\square}$ \\
\hline$\frac{0}{\infty}$ & & 동 & $\frac{9}{9}$ & $\Phi$ & $\begin{array}{l}\text { Paracrasp. oppres } \\
\text { sus (Epilaugeites) }\end{array}$ & Epivirgatites & $\begin{array}{l}\text { Epilaugeites } \\
\text { vogulicus }\end{array}$ & Epivirgatites & Buchia & \begin{tabular}{|c|}
11 \\
Epilaugeites \\
vogulicus
\end{tabular} & $\prod_{11}$ \\
\hline$\frac{\infty}{\alpha}$ & 응 & 동 & & 윰ํำ & $\begin{array}{l}\text { Titanites } \\
\text { giganteus }\end{array}$ & & \begin{tabular}{|l} 
Laugeites \\
groenlandicus
\end{tabular} & & & \begin{tabular}{|l|}
12 Laugeites \\
groenlandicus
\end{tabular} & \\
\hline$引$ & 5 & 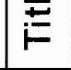 & & $\Sigma=$ & & & & & & & 12 \\
\hline
\end{tabular}


altitude in section 20 together with Pavlovia (Pallasiceras) cf. rotundiformis (plate 2, fig. 2) and Buchia ex gr. volgensis. In section 19 (Appendix) which is situated in a small creek immediately west of section 20 a rich assemblage of Laugeites parvus was found at the same altitude. Elsewhere in the area the zone has been demonstrated in south-western Kuhn $\varnothing$ (sections 5 and 7 (Appendix)) and northern Wollaston Forland (section 33a (Appendix)).

The age of the zone is late Middle Volgian (fig. 1; table 1) (Zahkarov \& Mesezhnikov, 1974).

\section{Epilaugeites vogulicus Zone (plate 2, fig. 4; plate 3)}

The zone is characterized by the index fossil Epilaugeites vogulicus (Ilovaisky) but indeterminable pavlovid ammonites were also found. A large assemblage of $E$. vogulicus was found at $88 \mathrm{~m}$ in section 20 (plate 2, fig. 3; plate 3). The zone has also been identified in the Raukelv Formation, Jameson Land by Surlyk et al. (1973).

The age of the zone is latest Middle Volgian (fig. 1) (Zakharov \& Mesezhnikov, 1974).

\section{'Virgatosphinctes' tenuicostatus beds (plate 4)}

None of the index fossils of the well known Upper Volgian ammonite zones of the Russian Platform, Siberia and England have been found in the Wollaston Forland area, although the presence of a relatively thick Upper Volgian succession can be demonstrated. This part of the succession is consequently given the informal biostratigraphic name 'Virgatosphinctes' tenuicostatus beds after the most characteristic ammonite (plate 4). The ammonites referred to Virgatosphinctes by Shulgina (1967) do not belong to this Tethyan genus according to Zeiss (personal communication, 1977). They are here described as 'Virgatosphinctes' since they cannot be satisfactorily placed in any other genus and the quality of the Wollaston Forland material does not allow the erection of a new genus. 'Virgatosphinctes' tenuicostatus Shulgina occurs in section 20 from $175-180 \mathrm{~m}$. On the south slope of Niesen ' $V$.' tenuicostatus has been found together with ' $V$.' cf. bicostatus Shulgina.

According to Shulgina (1967) 'V.' tenuicostatus occurs throughout the Upper Volgian zones of Craspedites okensis, Craspedites taimyrense, and Chetaites chetae. Its position in section $20 \mathrm{c} .100 \mathrm{~m}$ above the top Middle Volgian index species Epilaugeites vogulicus, c. $20 \mathrm{~m}$ below the earliest Ryazanian species Praetollia maynci Spath and $60 \mathrm{~m}$ below Hectoroceras kochi Spath suggests a position of the 175-180 m locality fairly high in the Upper Volgian and thus probably higher than the lowest subzone of the $C$. okensis Zone, i.e. the 'Virgatosphinctes' exoticus Subzone. Spath (1952, plate 4, figs 1,4) figured a species of Subcraspedites which Casey (1973, p. 239) referred to Subcraspedites (Swinnertonia) indicative of an early Late Volgian Age. The specimen origins from one of the highest conglome- 
rate beds in the Laugeites Ravine Member on Kuhn $\varnothing$ and not as written by Casey (op. cit.) from the "Basal Conglomerate (Laugeites Beds) of Wollaston Forland". Surlyk et al. (1973) figured a Subcraspedites cf. plicomphalus (J. Sowerby) from the higher part of the Raukelv Formation, Jameson Land. The specimen can probably be referred to Subcraspedites (Subcraspedites) and may be conspecific with $S$. (S.) sowerbyi Spath from the middle Upper Volgian $S$. (S.) preplicomphalus Zone of Casey (1973). Still higher from the Raukelv Formation an assemblage of the index species of the latest Upper Volgian Chetaites chetae Zone was found (Surlyk et al., 1973). There is consequently plentiful evidence for the presence of probably all of the Upper Volgian in East Greenland.

In the Wollaston Forland area the Upper Volgian is probably represented in section 20 by approximately $85 \mathrm{~m}$ of sandstones and conglomerates of the Rigi Member overlying the Laugeites Ravine Member at $115 \mathrm{~m}$ with angular unconformity (fig. 5).

\section{Praetollia maynci Zone (plate 5, figs 1-4)}

The lower boundary of the zone is defined by the first appearance of Praetollia maynci Spath and the upper boundary by the first appearance of Hectoroceras kochi Spath.

The type locality of the index species is section 20, $235 \mathrm{~m}$ (coll. Maync, described by Spath, 1952). The zone is new but seems to be justified since the index fossil is known to occur in all East Greenland localities where strata of latest Volgian-earliest Ryazanian age crop out (Surlyk, 1973). Furthermore, the species has a much wider geographic distribution than assumed by most previous authors. Thus Shulgina (1972) records $P$. maynci from the lowest Ryazanian Zone of Chetaites sibiricus and the lower part of the Hectoroceras kochi Zone of the Paks Peninsula, northern Siberia. In Jameson Land, East Greenland, $P$. maynci and $H$. kochi show a considerable overlap and only a few poorly preserved specimens of $P$. maynci have been found below $H$. kochi, but the poor development of the maynci Zone is easily explained by the presence of an important angular unconformity at the base of the kochi Zone (Surlyk, 1973).

In section $20 P$. maynci was found at $c .200 \mathrm{~m}$ followed at $240 \mathrm{~m}$ by the first $H$. kochi.

The age of the zone is probably earliest Ryazanian and it is thought to correlate with the Chetaites sibiricus Zone of Siberia and the Praetollia (Runctonia) runctoni Zone of eastern England.

\section{Hectoroceras kochi Zone (plate 5, figs 5-13)}

The zonal boundaries are defined by the first appearance of Hectoroceras kochi Spath and Surites (Caseyiceras) analogus (Bogoslovsky). The type locality of $H$. $k o c h i$ is in southern Jameson Land above strata with co-occurring $P$. maynci and $H$. kochi. In section $20 \mathrm{H}$. kochi first appears at $240 \mathrm{~m}$ whereas the last appearance is at 
c. $300 \mathrm{~m}$. At $272 \mathrm{~m}$ an ammonite assemblage was found including $H$. kochi and Pseudocraspedites anglicus (Shulgina) (plate 5, figs 6-13).

The $H$. kochi Zone is probably the best time marker in the Boreal Berriasian/Ryazanian as it occurs in East Greenland, Eastern England, Northern Urals and Siberia. H. kochi was recently found in the Russian Platform zone of Riasanites rjasanensis by Mesezhnikov et al. (1977). This important find proves the correlation of the kochi and rjasanensis Zones and substantiates the proposed correlation of the rjasanensis Zone with the Tethyan Upper Berriasian Zone of Fauriella boissieri (see e.g. Saks \& Shulgina, 1974). The age of the H. kochi zone is late Early Ryazanian (fig. 1).

\section{Surites (Caseyiceras) analogus Zone (plate 6)}

This zone is represented by an isolated assemblage from section $15,250 \mathrm{~m}$ comprising large Buchia volgensis and poorly preserved ammonites which are referred to Surites (Caseyiceras) analogus (Bogoslovsky) with some uncertainty. Its stratigraphic relations with $H$. kochi are not clear, however. The altitude is almost the same as the first occurrence of $H$. koch i in section 20. Section 15 is located on the north slope of Niesen $1.5 \mathrm{~km}$ west of section 20 (fig. 3). The $250 \mathrm{~m}$, section 15 locality is probably stratigraphically younger than the $240 \mathrm{~m}$, section 20 locality as the sequence thickens considerably towards the west accompanied by a slight westwards dip.

Almost identical ammonites recorded as Surites cf. or aff. poreckoensis Sazonov by Surlyk et al. (1973) occur in Jameson Land in the highest beds with H. kochi.

The age of the zone is early Late Ryazanian (fig. 1).

Surites tzikwinianus Zone (plate 7, fig. 1)

One specimen of Surites tzikwinianus (Bogoslovsky) was collected by the author in section 20, $305 \mathrm{~m}$, and Donovan (1964, pl. 7, fig. 1) figured an almost identical specimen also from $305 \mathrm{~m}$, probably the same section. According to Casey et al. (1977) the Surites tzikwinianus Zone in the Russian Platform occupies a position immediately above the equivalent of the Surites (Caseyiceras) analogus Zone and is of mid Upper Ryazanian Age.

\section{Bojarkia mesezhnikovi Zone (plate 7, figs 2-3)}

There is no direct fossil evidence of this zone in section 20. An assemblage of ammonites which can be referred to Bojarkia mesezhnikovi Shulgina was found at 451-454 m altitude, section 50 Palnatokes Bjerg (fig. 3).

The zone is of latest Ryazanian Age (Shulgina, 1972).

\section{Tollia tolli Zone (plate 8, fig. 1)}

Tollia tolli Pavlow or a closely related form was collected c. $25 \mathrm{~m}$ above Bojarkia mesezhnikovi in section $50,478 \mathrm{~m}$. The specimen might also be referred to Neotol- 
lia Shulgina, but the differences between the two genera listed by Shulgina (1972) are so subtle that Neotollia is here considered a junior synonym of Tollia.

The age of Tollia tolli is somewhat doubtful but most authors seem to agree on a very early Valanginian age (fig. 1) (Jeletzky, 1973) or latest Ryazanian-earliest Valanginian (Shulgina, 1972).

Buchia keyserlingi Zone (plate 7, figs 4-6; plate 8, figs 2, 4)

The main part of the Valanginian Stage in the Wollaston Forland area is somewhat difficult to divide biostratigraphically for the following reasons. The Valanginian Palnatokes Bjerg Formation forms the top bed in most of its distributional area and is thus exposed in scattered outliers in inland sections. It has therefore been less intensely collected than the biostratigraphically more interesting Jurassic-Cretaceous boundary horizons. The most fossiliferous Valanginian sequences are located on the uptilted crests of the underlying fault-blocks and are often strongly condensed. This is the case with most sections in the Rødryggen Member and some of the Albrechts Bugt Member sections. The ammonite assemblages described from the Valanginian of Traill $\varnothing$ by Donovan (1953) thus originates from these two members. Donovan (1953, p. 33) states that his material is collected in scree, and on the basis of the lithology and comparisons with my own stratigraphically well located collections there is no doubt that Donovan's material is mixed. The fauna was placed in the latest Lower Valanginian by Jeletzky (1973). The Traill $\varnothing$ ammonites are at present being re-studied by P. F. Rawson (London) and more detailed determinations of the present material will consequently have to await his conclusions.

Species of Buchia are extremely common throughout the Valanginian of the Wollaston Forland area. They seem to occur in the same general succession as in Western British Columbia and Arctic Canada (e.g. Jeletzky, 1973). The Buchia zones of Jeletzky $(1973)$ and Kemper $(1975,1977)$ can thus be applied in East Greenland.

Kemper (1977) defines the lower limit of the Valanginian by the first appearance of Platylenticeras and states that this boundary coincides approximately with the first appearance of Buchia keyserlingi (Lahusen) in the boreal-arctic regions. B. keyserlingi occurs in often enormous abundances in Wollastan Forland and its first appearance can be easily located in most sections. The age of the zone is Early and earliest Late Valanginian (Kemper, 1977).

Polyptychites keyserlingi (Neumayr \& Uhlig) occurs scattered in eastern Wollaston Forland together with Buchia inflata (Toula) and abundant Buchia keyserlingi (Lahusen) suggestive of a late Lower Valanginian Age.

Buchia sublaevis Zone (plate 8, fig. 3)

Buchia sublaevis (Keyserling) occurs scattered in the upper part of the range of 
B. keyserlingi and above. The zone can be dated as Lower Upper Valanginian (Jeletzky, 1973; Kemper, 1975, 1977).

Buchia crassicollis Zone (plate 8, fig. 5)

Buchia crassicollis (Keyserling) was found at the top of Niesen (688 m) together with Homolsomites? and a possible fragment of Virgatosphinctes. Spath (1946) recorded the presence of Lyticoceras from the same locality. These strata are of latest Valanginian Age.

\section{SEDIMENTOLOGY}

\section{Methods}

Practically all the information necessary for the interpretation of the sedimentary processes and environments was obtained in the field. Laboratory work has been carried out only to gather supplementary data on grain size, sorting, petrography, texture. Such data were obtained by examination of thin sections of all the main rock types, and by X-ray diffractometry of the finer-grained sediments. Point-counts of a number of thin sections were carried out in order to classify the non-conglomeratic facies, as well as the matrix of the conglomerates. Grain size and degree of sorting were studied in thin sections or by wet sieving of the sediment after treatment with dilute $\mathrm{HCl}$, and by pipette analyses for the finer-grained sediments. The results of the laboratory investigations are treated in more detail under the individual facies descriptions.

In the present study laboratory investigations add only very little to the understanding of the depositional processes and environments partly because of the very coarse-grained nature of the sediments, whereas detailed and pertinent field observations are of paramount importance.

As many vertical logs as possible were, therefore, measured. The logs are drawn with the left column showing lithology and with the right column showing physical sedimentary structures (Appendix). The abscissa of the right column shows the grain sizes (compare Selley, 1970). Body fossils, trace fossils, and bioturbation are indicated to the right of the log. Where the sediment is lying horizontal the actual altitudes are indicated along the left margin of the log whereas dipping sections only have a scale. All logs are drawn at the same scale with the exception of a few which have been shown in more detail.

During section measuring several sedimentological parameters were recorded whenever possible. For convenience all measurements associated with one log were carried out within a $5 \mathrm{~m}$ wide strip (compare Clifton, 1973). They include measurement of the 12 largest pebbles of each conglomeratic bed. The maximum pebble size was then calculated as the average after the omission of the two largest clasts. This was done to exclude the very strong bias introduced by one or two exceptionally large boulders. The average maximum pebble size is shown at the right side of the log with black dots. The diameter of the single largest clast is shown with an open circle. It was not always possible to measure 12 clasts in every bed within a single profile owing to the often very steep nature of the outcrop. Clast imbrication was measured normally for 10 clasts. These measurements are shown in rose 
Table 2. Scheme of facies of the Wollaston Forland Group

\begin{tabular}{|c|c|c|c|c|c|}
\hline Facies & Grain size & Structures and/or textures & Appearance in $\log$ & Set boundaries & Interpretation \\
\hline 1. Dark mudstone & Clay to coarse silt & Parallel lamination & & $\begin{array}{l}\text { Lower and upper } \\
\text { boundary sharp }\end{array}$ & $\begin{array}{l}\text { Deposition from suspension } \\
\text { in low-energy euxinic } \\
\text { environment }\end{array}$ \\
\hline $\begin{array}{l}\text { 2. Light grey } \\
\text { mudstone }\end{array}$ & $\begin{array}{l}\text { Clay to coarse silt } \\
\text { and occasionally fine } \\
\text { sand }\end{array}$ & $\begin{array}{l}\text { All transitions from } \\
\text { parallel lamination to } \\
\text { total burrow mottling }\end{array}$ & $=$ & $\begin{array}{l}\text { Lower and upper boundary } \\
\text { sharp or transitional }\end{array}$ & $\begin{array}{l}\text { Deposition from suspension } \\
\text { in low-energy normally well } \\
\text { oxygenated environment }\end{array}$ \\
\hline 3. Red mudstone & $\begin{array}{l}\text { Clay to coarse silt } \\
\text { with some admixture of } \\
\text { fine sand }\end{array}$ & $\begin{array}{l}\text { Usually total burrow mott- } \\
\text { ling; intraformational } \\
\text { breccias and slump struc- } \\
\text { tures }\end{array}$ & $E$ & $\begin{array}{l}\text { Boundaries usually } \\
\text { transitional }\end{array}$ & $\begin{array}{l}\text { Slow deposition from } \\
\text { suspension in strongly } \\
\text { oxidizing environment. } \\
\text { Occasional redeposition. }\end{array}$ \\
\hline $\begin{array}{l}\text { 4. Interlaminated } \\
\text { mudstone and } \\
\text { fine sandstone }\end{array}$ & $\begin{array}{l}\text { Mud: Clay to coarse silt } \\
\text { with some fine sand. } \\
\text { Sand: Usually fine; may } \\
\text { be pebbly }\end{array}$ & $\begin{array}{l}\text { Mud: Parallel lamination. } \\
\text { Sand: Parallel lamination. } \\
\text { Occasionally ripple-lami- } \\
\text { nation. Thicker sets graded. }\end{array}$ & & $\begin{array}{l}\text { Boundaries usually } \\
\text { sharp and erosional }\end{array}$ & $\begin{array}{l}\text { Mud settled out from suspen- } \\
\text { sion in low-energy environmen } \\
\text { Sand may represent reworked } \\
\text { storm layers or turbidites. }\end{array}$ \\
\hline $\begin{array}{l}\text { 5. Graded sand- } \\
\text { stone with } \\
\text { subhorizontal } \\
\text { base }\end{array}$ & $\begin{array}{l}\text { Fine to coarse sand. } \\
\text { Some beds have a pebbly } \\
\text { or conglomeratic base }\end{array}$ & $\begin{array}{l}\text { Structureless base followed } \\
\text { by parallel lamination and } \\
\text { occasional ripple-lamination. } \\
\text { Grading of both maximum and } \\
\text { median grain size. }\end{array}$ & & $\begin{array}{l}\text { Boundaries sharp. Lower } \\
\text { boundary may be erosional }\end{array}$ & $\begin{array}{l}\text { Deposition from flows } \\
\text { transitional between grain } \\
\text { flows, liquefied flows and } \\
\text { turbidity currents with the } \\
\text { latter two types being the most } \\
\text { important. }\end{array}$ \\
\hline $\begin{array}{l}\text { 6. Structureless, } \\
\text { non-graded } \\
\text { sandstone }\end{array}$ & $\begin{array}{l}\text { Medium-to very coarse } \\
\text { pebbly sand }\end{array}$ & Structureless & & $\begin{array}{l}\text { Both boundaries sharp. } \\
\text { Lower boundary may be } \\
\text { erosional }\end{array}$ & $\begin{array}{l}\text { Deposition from flows } \\
\text { transitional between } \\
\text { liquefied flows and turbidity } \\
\text { currents. }\end{array}$ \\
\hline \multicolumn{6}{|l|}{$\begin{array}{l}\text { 7. Graded sand- } \\
\text { stone deposited } \\
\text { in channels }\end{array}$} \\
\hline $\begin{array}{l}\text { a. Channels wide } \\
\text { and shallow }\end{array}$ & $\begin{array}{l}\text { Coarse pebbly sand } \\
\text { grading into fine } \\
\text { sand or mud }\end{array}$ & $\begin{array}{l}\text { Distribution grading. Upper } \\
\text { part may be laminated con- } \\
\text { formable to the shape of the } \\
\text { channel base }\end{array}$ & & $\begin{array}{l}\text { Lower boundary always } \\
\text { erosional. Upper boundary } \\
\text { erosional or transitional }\end{array}$ & \multirow{2}{*}{$\begin{array}{l}\text { Deposition from high density } \\
\text { turbidity currents or from } \\
\text { flows transitional to } \\
\text { liquefied flows and possibly } \\
\text { to grain flows }\end{array}$} \\
\hline $\begin{array}{l}\text { b. Channels very } \\
\text { deep, often } \\
\text { symmetrical }\end{array}$ & $\begin{array}{l}\text { Usually conglomeratic } \\
\text { base grading into coarse } \\
\text { pebbly sandstone }\end{array}$ & $\begin{array}{l}\text { Distribution grading. } \\
\text { Clasts show long-axis } \\
\text { imbrication }\end{array}$ & $\because \because \vdots 1$ & $\begin{array}{l}\text { Lower boundary always } \\
\text { erosional. Upper boundary } \\
\text { usually erosive }\end{array}$ & \\
\hline
\end{tabular}




\begin{tabular}{|c|c|c|c|c|c|}
\hline Facies & Grain size & Structures and/or textures & Appearance in log & Set boundaries & Interpretation \\
\hline $\begin{array}{l}\text { 8. Conglomerates } \\
a \text {. Non-graded, } \\
\text { matrix } \\
\text { supported, } \\
\text { disorganized }\end{array}$ & $\begin{array}{l}\text { Matrix coarse, pebbly } \\
\text { sand. Clasts usually } \\
\text { coarse cobbles or } \\
\text { boulders }\end{array}$ & Structureless & 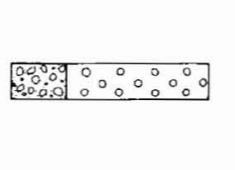 & $\begin{array}{l}\text { Both boundaries usually } \\
\text { erosive. Boundaries may } \\
\text { be sharp but non- } \\
\text { erosional }\end{array}$ & $\begin{array}{l}\text { Deposition from sandy debris } \\
\text { flows transitional to density- } \\
\text { modified grain flows }\end{array}$ \\
\hline $\begin{array}{l}\text { b. Non-graded, } \\
\text { clast supported, } \\
\text { disorganized }\end{array}$ & as $a$. & Structureless & 00900000 & as $a$. & $\begin{array}{l}\text { Deposition from density- } \\
\text { modified grain flows } \\
\text { transitional to sandy debris } \\
\text { flows }\end{array}$ \\
\hline $\begin{array}{l}\text { c. Non-graded, } \\
\text { imbricated }\end{array}$ & as $a$. & $\begin{array}{l}\text { Clasts show long-axis } \\
\text { imbrication }\end{array}$ & 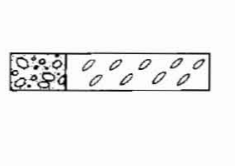 & as $a$. & $\begin{array}{l}\text { Deposition from density- } \\
\text { modified viscous or inertial } \\
\text { grain flows (matrix and } \\
\text { grain supported end-members } \\
\text { respectively) }\end{array}$ \\
\hline d. Graded & as $a$. & Distribution grading & F80\% & as $a$. & $\begin{array}{l}\text { Deposition from sandy debris } \\
\text { flows where some vertical and } \\
\text { lateral clast segregation has } \\
\text { taken place }\end{array}$ \\
\hline $\begin{array}{l}\text { e. Graded, imbri- } \\
\text { cated }\end{array}$ & as $a$. & $\begin{array}{l}\text { Distribution grading. Clasts } \\
\text { show long-axis imbrication }\end{array}$ & 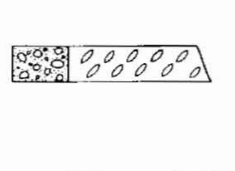 & as $a$. & $\begin{array}{l}\text { Flows transitional between } \\
\text { sandy debris flows, density- } \\
\text { modified grain flow (and } \\
\text { perhaps high density turbidity } \\
\text { currents). }\end{array}$ \\
\hline $\begin{array}{l}f . \text { Inverse-to-nor- } \\
\text { mally graded }\end{array}$ & as $a$. & $\begin{array}{l}\text { Coarse tail grading of base. } \\
\text { Upper part distribution } \\
\text { graded. Clasts usually showing } \\
\text { long-axis imbrication }\end{array}$ & 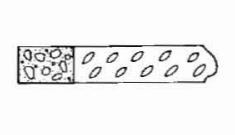 & as $a$. & $\begin{array}{l}\text { Deposition from inertial } \\
\text { density-modified grain } \\
\text { flows }\end{array}$ \\
\hline g. Composite & $\begin{array}{l}\text { as } a \text {. but containing } \\
\text { discontinuous layers and } \\
\text { lenses of sand }\end{array}$ & $\begin{array}{l}\text { Conglomeratic parts may } \\
\text { represent all previous } \\
\text { subfacies }(\mathrm{a}-\mathrm{f}) \text {. Sand graded } \\
\text { or non-graded. Usually struc- } \\
\text { tureless. }\end{array}$ & 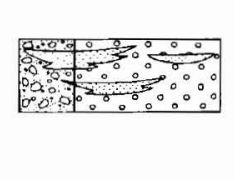 & $\begin{array}{l}\text { Boundaries almost } \\
\text { impossible to define }\end{array}$ & $\begin{array}{l}\text { Results from progressive } \\
\text { failure on a slope, producing } \\
\text { a series of retrogressive } \\
\text { flows involving earlier } \\
\text { deposited beds of subfacies a- } \\
\text { as well as sandstone facies } 5-7\end{array}$ \\
\hline
\end{tabular}


9. Stratified pebble con-

Fine to coarse con-

glomerate
Horizontal stratification

outlined by thin layers of

pebbles in a matrix of

$\because \ldots$

coarse sandstone
Boundaries planar,

erosional or non-

erosional
Granules and pebbles transported

by bedload traction, whereas

sand was deposited directly

from suspension
10. Breccias $\quad$ Boulders, mainly $0.5-1 \mathrm{~m}$

in diameter. Matrix if

present very coarse

Usually disorganized

Imbrication of clasts

may occur

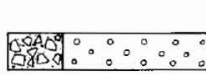

Boundaries poorly

defined

Deposition from submarine rock-

fall avalanches passing

into sandy debris flows and density-modified grain flows 
diagrams to the right of the logs. In many cases it was only possible to measure the 'average' or general trend of up-dip directions of the imbricated clasts in a conglomerate bed. These trends are indicated with arrows. Where present, imbrication is very well developed and with little spreading of measurements in individual beds. Several repetitive estimates as well as precise measurements of imbrication of the same bed for control purpose showed that it was possible to estimate the trends with great precision. The average of all pebble-imbrications in the whole area is $74^{\circ}$, whereas the average of all trend estimates in the same area is $86^{\circ}$. These almost identical results strongly suggest that the trend estimates are reliable and significant data. In a few cases it was possible to measure the axes of channels; they are indicated in the same place as the arrows showing the imbrication trends. Pebble counts on a surface of one square metre of conglomerate were carried out at some localities. Since the clast assemblages are very uniform (normally comprising only gneisses and quartzites) only a few counts were taken, and qualitative estimates made of major lateral or vertical changes.

The coarse clastic sediments were interpreted by Maync (1947) as deltaic fluvio-marine. Therefore the measurements proposed by Clifton (1973) as means of distingushing between fluviatile and wave-worked gravels were applied, although it became clear during field work that the sediments had been redeposited by sediment gravity flows. The most useful parameter is pebble segregation - a measure of the percentage of pebbles as opposed to matrix in the conglomerate. This parameter was measured whenever possible and is shown with a figurative symbol to the right of the log (Appendix). A pebble segregation of $90-100$ per cent comprises a framework conglomerate (clast supported) without matrix; 70-90 per cent signifies a framework conglomerate with a matrix; 50-70 per cent signifies a non-framework conglomerate (matrix supported) with abundant clasts etc.

It must be strongly emphasized that whenever measures of relative abundance such as sand:shale ratio of a particular facies are given, these are strongly biased in favour of the coarser facies. This is easily explained as being a result of the nature of exposure and much stronger compaction of fine-grained facies. The conglomerate beds form steep cliffs whereas the sandstones and mudstones are often covered with scree. The measurements are thus only valid for the detailed sections, and finer-grained portions probably would be of greater importance had there been more complete exposure.

\section{Sedimentary facies}

The term facies is used here according to the original definition of Gressly (1838). A more recent review of the facies concept was given by Teichert (1958) who concluded that facies is the sum total of all primary characteristics of a sedimentary rock.

The delimitation of individual facies is determined by grain size, composition, sedimentary structures, degree and nature of bioturbation, fossil content and possibly chemical or other parameters. The facies analysis is here based mainly on a large number of measured vertical sections and a few lateral profiles.

It would have been possible to have made a very detailed subdivision into numerous facies but this has been avoided for reasons of clarity. The different facies are recognized on the basis of an analysis of the vertical logs and are described below, starting with the more fine-grained and ending with the coarser grained facies. They are summarized in table 2 . 


\section{Dark mudstone}

\section{Description}

The facies covers a wide range of grain sizes from claystone to coarse-grained siltstone. Abundant large mica flakes characterize the sediment, whilst comminuted plant debris and larger plant fragments are also common. The mudstones everywhere show horizontal parallel lamination that has only rarely been disturbed by bioturbation. The lamination is a primary structure and reflects subtle grain size differences. Ammonites and Buchia are found in some horizons. The facies characterizes parts of the Laugeites Ravine and Niesen Members.

\section{Interpretation}

The fine-grained nature of the sediment and the absence of current-produced structures suggest deposition in a low energy environment where the sediment settled out from suspension. The changes in grain sizes corresponding to the lamination are produced by pulses in deposition. The occurrence of ammonites and Buchia indicates that the depositional environment was marine and the absence of a normal benthic fauna suggests poor oxygenation at the sediment-water interface possibly accompanied by high turbidity.

\section{Light grey mudstone}

\section{Description}

The facies mainly covers sediments in the clay and silt fractions with some admixture of fine-grained sand. Larger particles are practically all skeletal carbonate grains. The facies may show perfect horizontal lamination, or vague lamination, or burrow mottling of totally massive bedding. Well defined trace fossils, especially Zoophycos, are common. At some horizons the mudstone has a low $\mathrm{CaCO}_{3}$ content, and calcareous concretionary nodules and layers occur abundantly. Kaolinite and illite occur in almost equal amounts, whereas montmorillonite is absent and chlorite is found in only very small amounts. The facies was investigated for nannofossils with a scanning electron microscope but with negative result. Marine fossils are very common in certain beds. Buchia dominates the assemblages, whereas belemnites and ammonites are rare. The ammonites are preserved as moulds which show signs of solution and abrasion (compare Seilacher, 1973). This facies is typical for the Albrechts Bugt Member. 
Interpretation

The fine grain size and the absence of structures indicative of currents suggest deposition from suspension. The depositional environment was marine and the strong bioturbation indicates the former presence of a normal benthic fauna. The preservation of the ammonites suggests repeated reworking and burial interrupted by periods of exposure on the sea-bottom.

\section{Red mudstone}

\section{Description}

This facies comprises massive or weakly laminated dark-red mudstones. There are scattered occurrences of intraformational breccias and conglomerates composed of centimetre-sized randomly orientated mudstone clasts, and rapid irregular changes to green shades are commonly observed. The mudstones are normally non-calcareous although there are some larger skeletal calcite grains. Calcite cemented horizons and concretions are, however, abundant. The matrix is composed of clay minerals and hematite whereas grains in the silt and fine sand fractions consist of subangular to subrounded quartz and skeletal grains - notably inoceramid prisms. Montmorillonite is absent and chlorite occurs in very small quantities, whereas illite and kaolinite occur in almost equal amounts. The latter have commonly been intensely bored by microborers. The facies is strongly bioturbated and well-preserved Zoophycos are characteristic. Buchia, ammonites, and belemnites are common to abundant, whereas whole inoceramids and brachiopods occur more rarely. The ammonites are preserved as moulds, and stratigraphical analysis shows the facies to be often highly condensed. The facies is characteristic of the Rødryggen Member. An identical facies of the same age occurs on the eastern side of the Atlantic Ocean on Andøy (Dalland, 1975).

\section{Interpretation}

The absence of current produced structures suggests deposition from suspension in a low energy environment. The fauna had a complicated burial history, but shows that the depositional environment was marine. The red colour indicates strongly oxidizing conditions in the environment of deposition or in the source area but environmental details of the area of provenance are unknown. Maync (1949) suggested a post-depositional terra rossa weathering of the Albrechts Bugt mudstones after emergence of the sediments. This explanation is untenable because the sediment and fauna of the red mudstone facies are different from those of the underlying light grey mudstones of the Albrechts Bugt Member. According to Dalland (1975) the Andøy rocks (Skjermyrbekken Member) are characterized by slump structures and the red colour is thought to be secondary, originated during a 
very short-lived uplift and weathering. This explanation of the red colour of the Andøy sediments as being of secondary origin must likewise be rejected. Offshore marine red-beds are well-known from the Lower Palaeozoic, where the red colour is explained as a result of rapid burial in quiet marine environments of sediments derived from oxidized source material (Ziegler \& McKerrow, 1975). Deposition of the facies below the carbonate compensation depth analogous to certain red interturbidite mudstones in the Alps (Faupl, 1976) is unlikely because the facies is restricted to palaeotopographic heights such as uplifted block-crests.

The facies in many respects resembles the famous Ammonitico Rosso of the southern Alps and Appennines (see Hallam, 1975), and is likewise interpreted as having been deposited very slowly in a strongly oxidizing environment on submarine shoals.

\section{Interlaminated mudstone and fine sandstone}

\section{Description}

This facies displays the 'coarsely interlayered bedding' of Reineck \& Singh (1973, p. 107) composed of alternating layers of thick mudstone and thinner fine-grained sandstone. The interlayering does not show any pronounced cyclicity. The mudstones have a relatively high content of angular quartz grains in the coarse silt to fine sand fraction. They show fine horizontal lamination and contain large flakes of mica and locally comminuted plant debris. The sand layers vary in thickness between a few millimetres and $10 \mathrm{~cm}$ with a mean value of about $1 \mathrm{~cm}$. They normally show parallel lamination, but ripple cross-lamination is seen in some layers and asymmetrical wave ripples are also preserved (fig. 8). Thicker sandstones may be graded. General transport directions measured on asymmetric wave ripples are unidirectional to the west. Bedding is only rarely modified by burrowing organisms. Ammonites and Buchia have a scattered occurrence. The facies is characteristic of part of the Laugeites Ravine and Niesen Members.

\section{Interpretation}

The horizontally laminated mudstone probably settled out af suspension in a mainly low-energy environment. The lack of regular rhythmical bedding suggests that sand was occasionally transported in an environment normally characterized by deposition of mud. Mud sedimentation might have been interrupted by heavy storms during which sand from more near-shore regions was carried offshore. The parallel lamination of the sand may be a result of settling out of suspended material after passage of storms (Reineck \& Singh, 1972). Some sands may also have been deposited from turbidity currents. The scattered occurrences of well-defined asymmetrical wave ripples suggest that wave base was lowered during stormy periods. The ripple transport direction is to the west towards the land. 


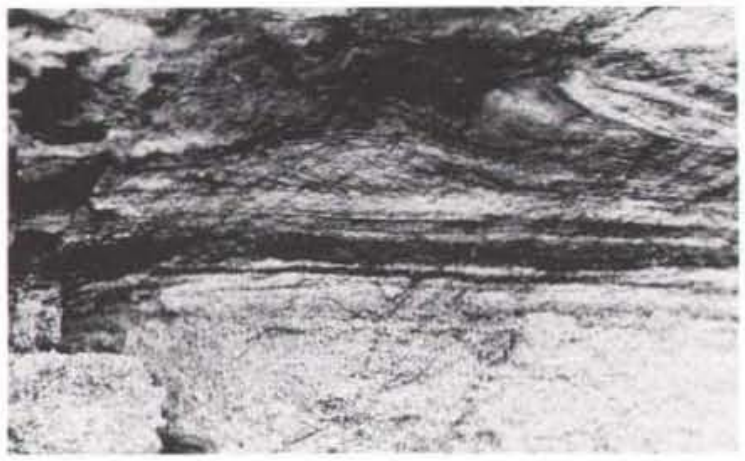

Fig. 8. Asymmetric wave ripple in the mudstones of the Laugeites Ravine Member. At the base of the photograph a structureless $10 \mathrm{~cm}$ sandstone with a few horizontal laminae on top. Section $20^{1}$ (Appendix), Niesen, north Wollaston Forland, about $15 \mathrm{~m}$ above base of section.

\section{Graded sandstone with subhorizontal base}

\section{Description}

This facies encompasses a rather wide array of rock types. The beds vary in thickness from a few centimetres to about $10 \mathrm{~m}$ and in one exceptional case to more than $20 \mathrm{~m}$ (section $14^{2}$, Appendix). The bases of the individual beds are always sharp; the tops are normally sharp but may be gradational to overlying mudstone. The sand fraction covers grain sizes from very fine to coarse sand with medium sand being the most common. The more fine-grained sandstones may, however, have a large content of silt. The sandstones are composed of angular quartz grains and small amounts of feldspar and mica. The matrix content is normally low averaging 1 per cent. The beds normally grade from medium to very fine sand. Some thicker beds show a pebbly sandstone or even conglomeratic base, but grade rapidly into medium sand. The grading normally reflects a decrease in both maximum and median grain size, but the coarse-tail grading is the most conspicuous. Inverse grading has been observed in a few cases.

The graded sandstones may be structureless throughout. This is especially the case with the thicker beds, such as the $10 \mathrm{~m}$ sandstone in section $18^{3}$ (Appendix). In other cases the graded structureless division passes into an even parallel laminated division, often with parting lineation and which may contain trace fossils such as Ancherichnus (Heinberg, 1974). An isolated sequence in eastern Kuhn $\varnothing$ contains a number of thin graded sandstones each showing a graded division followed in most cases by a parallel laminated division which in turn is followed by a current ripple laminated division (Surlyk \& Clemmensen, 1975a).

Except in eastern Kuhn Ø the measured sections contain a total of 51 structureless graded beds ( 68 per cent of beds), 17 graded even parallel laminated beds ( 23 per cent), 6 beds with a lower graded division passing into an even parallel laminated division ( 8 per cent), and 1 bed ( 1 per cent) showing an even parallel laminated graded division overlain by a current ripple laminated division. In this connection it 
should be noted that some of the even parallel laminations result from weathering and diagenesis, therefore the number of beds belonging to this category may be exaggerated.

The graded sandstones are normally separated from each other by mudstones, but may form amalgamated beds (Walker, 1967) as in section $18^{5}$ (Appendix). The beds have a lateral continuity of a few tens of metres. Some thinner sandstones may display irregular flaser structures. Carbonized plant fragments are locally abundant. Burrows and marine fossils such as ammonites and Buchia are locally common.

In general the facies resembles facies C of Walker (1973) but the sandstones tend to be coarser grained and thicker bedded.

\section{Interpretation}

The combination of a lower graded division and an upper horizontally laminated division together with the sharp base of the beds and the occurrence of marine fossils suggests deposition from turbidity currents in a marine environment. The lower structureless part of the graded sequence corresponds to the 'graded interval' or 'A division' of the idealized turbidite sequence (Bouma, 1962), whilst the horizontally laminated sequence corresponds to the 'B division' of the Bouma sequence. These two divisions were probably deposited during upper flow regime conditions (Harms \& Fahnestock, 1965) with the A division being deposited during the most rapid flow (Walker, 1965). The great thickness (several metres) of the majority of the sandstones, showing only the $\mathrm{A}$ and $\mathrm{B}$ divisions, and the dominance of the A division (68 per cent of beds) or beds beginning with the A division ( 76 per cent of beds) suggests that the facies comprises proximal turbidites of Walker (1967).

The structureless, and in particular the inversely graded beds resemble also the postulated grain flow deposits of Stauffer (1967; see also Middleton \& Hampton, 1976). Lowe (1976a), however, demonstrated that thick, structureless sand beds in flysch sequences and similar units in other successions cannot have been deposited by true grain flows. There is probably a complete transition between density-modified grain flows and liquefied flows, and between true liquefied flows and turbidity currents (Lowe, 1976a, b). The beds showing both A and B divisions are therefore thought to have been deposited from high density turbidity currents and the beds showing only A divisions are interpreted as deposits of flows transitional between liquefied flows and turbidity currents. Finally the inversely graded beds probably were deposited from flows where dispersive pressure was aiding in maintaining the dispersion against gravity.

The facies thus represents deposits laid down from flows transitional between grain flows, liquefied flows and turbidity currents with the latter two types of flow being the most important. 


\section{Structureless, non-graded sandstone}

\section{Description}

The facies includes beds ranging in thickness from a few centimetres to several metres, with grain size varying from medium to very coarse pebbly sand. Petrographically the facies is identical to the former facies. Sorting is normally poor. The base and top of the beds are sharp and they may be traced laterally for some tens of metres. Marine fossils, notably Buchia, are scattered throughout. Plant fragments may be very common. The facies conforms with the description of facies B2 'massive sandstones without dish structures' - of Walker (1973).

\section{Interpretation}

The sharp bases, the lack of structures and the intimate association with the 'proximal turbidites' of the preceding facies might suggest deposition by sediment gravity flows and the beds might be classed as A divisions although many workers prefer not to describe beds of this type with the Bouma model. Lowe (1976b) has proposed that this type of facies probably represents the deposit of flows transitional between liquefied flows and turbidity currents. He suggested that slumps liquefied after failure and flows of liquefied sediment may evolve by the development of turbulence into high density currents. Slope decline and flow dispersion would be accompanied by a loss of flow power and a transition back into partially liquefied flows. Lowe's (1976b) interpretation is followed here, and the lack of water escape structures is thought to be due to the dominantly coarse grain size.

\section{Graded sandstone deposited in channels}

\section{Description}

This facies encompasses two rather different subfacies.

\section{Subfacies $7 \mathrm{a}$}

This subfacies comprises sandstones that were deposited in wide, shallow channels with a depth of $0.5-2 \mathrm{~m}$ and a width of 10-100 m (section 24, 33A, 34, 47 top part, 50 (Appendix), fig. 9). The sandstones show marked grading from coarsegrained, often pebbly sandstone or fine conglomerate at the base to fine-grained sandstones or mudstone at the top. The sandstones show a well-developed distribution grading, but coarse-tail grading in which there is a rapid disappearance of pebbles upwards from the base of the beds is also very conspicuous. The graded beds are either structureless or less commonly coarse parallel laminated conformable to the shape of the channel base so that the channel form is draped with 
Fig. 9. Wide flat channels filled with pebbly sandstones grading into medium or fine sandstones. Rigi Member, Niesen, north Wollaston Forland. Midfan association. Height of section is about 40 $\mathrm{m}$.

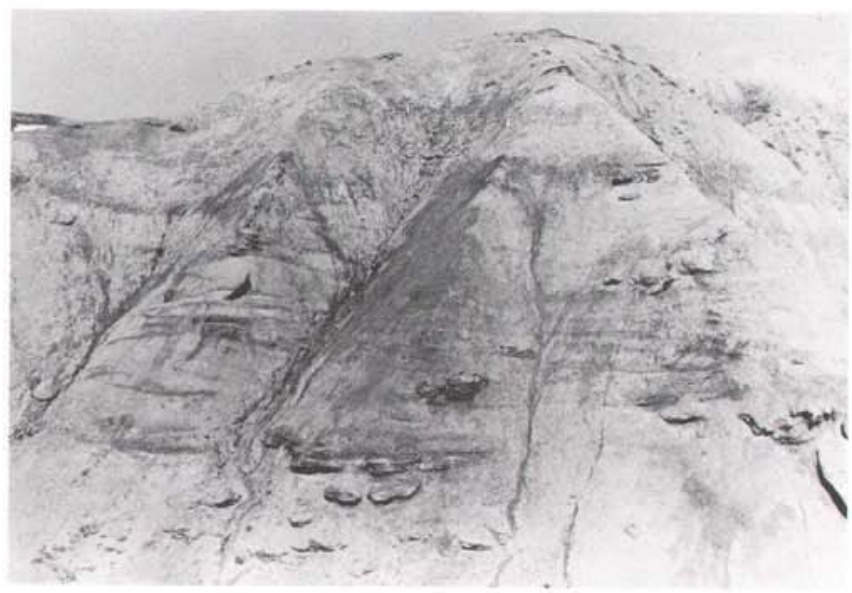

relatively thick sandstone laminae. In one case (section $15^{3}$, Appendix) current ripple lamination is developed in the top of a graded sandstone. Petrographically the facies is composed of angular grains of quartz, rock fragments and small amounts of feldspar and mica. The matrix content is very low $(<1-2$ per cent).

The base of the channels is, in many cases, veneered with a mudstone bed varying in thickness from less than $1 \mathrm{~cm}$ to about $25 \mathrm{~cm}$. The mudstone layer is well laminated and does not show any pronounced thinning towards the margin of the channels.

\section{Subfacies $7 b$}

The second subfacies comprises sandstones deposited in relatively deep often symmetrical channels. The channels can reach a depth of at least $20 \mathrm{~m}$ (section $14^{2}$, 160-180 m, Appendix). The channel fill is normally very coarse-grained and commences with pebbly sandstone or conglomerate. Grading is very pronounced and is a result of decrease in both maximum and median grain size (figs 10-14). The base of the beds is always strongly erosive and mudstone layers are never found draping the base. The sandstones are either structureless or show a more or less pronounced parallel bedding conformable with the channel base. Characteristically the channels are filled with a consecutive sequence of such beds, each one showing very good vertical as well as lateral grading, and becoming thinner and finer-grained upwards. This results in an overall vertical and lateral grading of the channel fill. The best example is shown on fig. 10 and figs $11-12$, where five beds fill a channel $75 \mathrm{~m}$ wide and at least $15 \mathrm{~m}$ deep.

The clasts at the base of the graded sandstones may show a pronounced imbrication especially when they are flat or ellipsoidal in shape. The up-dip directions of 

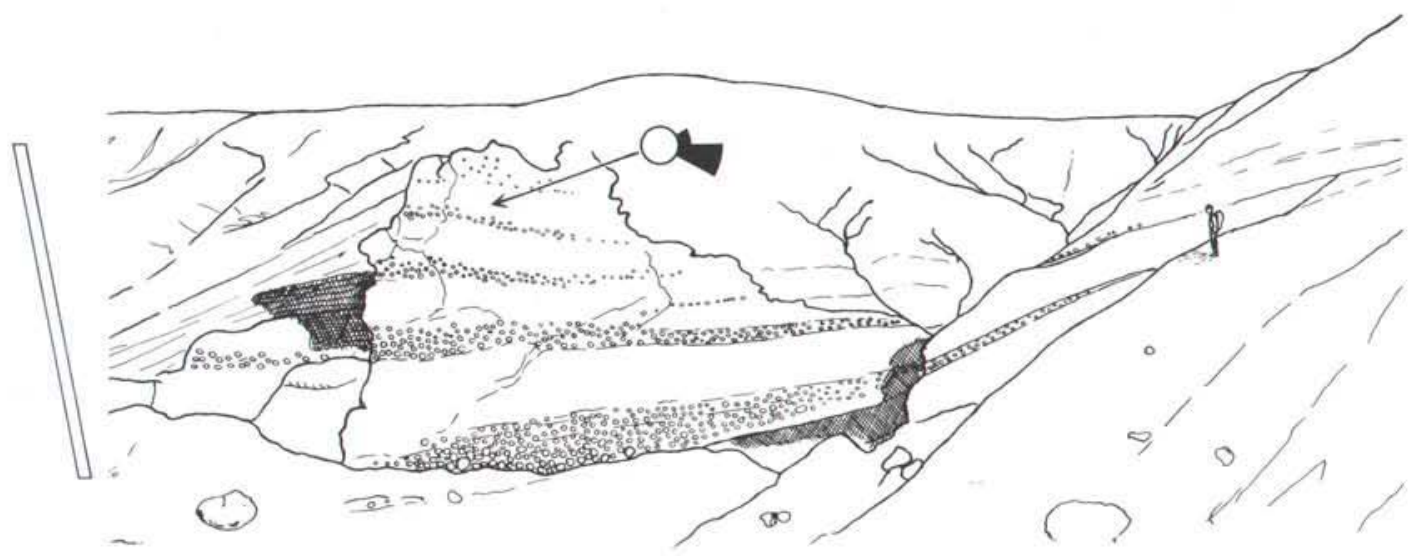

Fig. 10. Proximal midfan association. Section 51. NW side of Palnatokes Bjerg. Rigi Member; Upper Ryazanian. Very large symmetrical channel filled in five successive episodes by a sequence of upwards fining and thinning beds. Person to the right indicates scale. Details are shown in figs 11, 12, 20.

imbrication are always strongly unimodal and subparallel with the channel axes. The clasts mainly comprise well-rounded quartzites or gneisses, but in successions with abundant fine-grained material such as the Laugeites Ravine Member large mudstone clasts may occur in the lower parts of the channels. These clasts may be angular in shape indicating that the mudstone was relatively indurated at the time of erosion (figs 15-16), or they may show a more irregular, deformed outline. At one locality on western Kuhn $\varnothing$ the majority of the pebbles are water worn belemnites (figs 13-14). This is the only case observed where clast long axes are lying at a

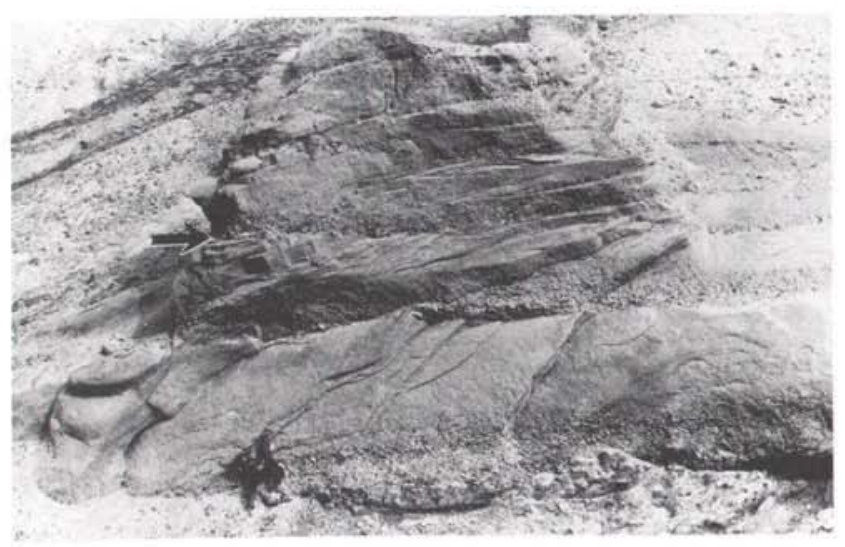

Fig. 11. Central part of large, regular, symmetrical channel filled by five successive beds each showing both fining and thinning upward. Each unit displays both vertical and lateral grading and is thicker and more coarse grained than the next overlying unit. The units are structureless except for a pronounced imbrication of the larger clasts. The channel (section 51) is also shown in fig. 10 and details are figured in figs $12,20$. Arrow shows position of fig. 12. Rigi Member, Palnatokes Bjerg in $340 \mathrm{~m}$ altitude. Proximal midfan association. 
Fig. 12. Detail of graded units of section 51 (arrowed in fig. 11). Clasts show a weak imbrication indicating current from right to left (W to E). The sequence is strongly jointed. Rigi Member, Palnatokes Bjerg. Proximal midfan association.

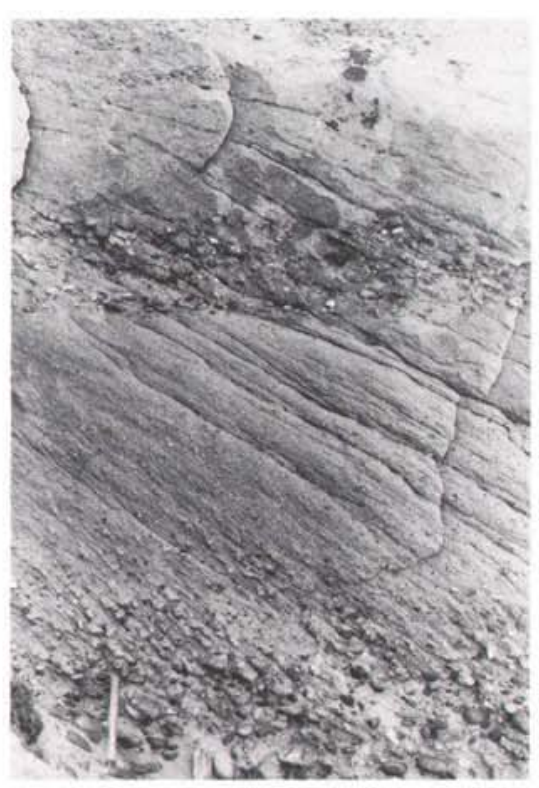

right angle to the channel axis. This subfacies always occurs in very coarse-grained sequences in juxtaposition with breccias and boulder conglomerates.

Both subfacies correspond to facies A4 - 'organized pebble sandstones' - of Walker (1973).

The facies contains rare marine fossils and occurs in fully marine sequences.

\section{Interpretation}

The pronounced grading, common clast imbrication, general lack of structures of both subfacies suggest deposition by sediment gravity flows transitional between liquefied flows and turbidity currents although dispersive pressure formed by clast collisions may have aided in supporting grains (see Lowe, 1976b; and discussion of the former facies). There is complete agreement with all the features listed by Walker (1967, table 2$)$ as characteristic of 'proximal turbidites'. The facies includes practically only A and A-E divisions. A-B divisions may occur, but it is difficult to see if the channel parallel bedding actually is a result of amalgamation of A divisions with decreasing grain size or if it is real B divisions. It is believed, however, that the latter cases are rare because in all instances where the grain sizes are large enough to include pebbles, each of the channel parallel beds starts with a pebbly zone or at least a thin pebble lag. This is a clear sign of successive periods of sedimentation and it is probably also the case where the beds are more well sorted and less clearly graded. According to several authors beds of this type cannot be 


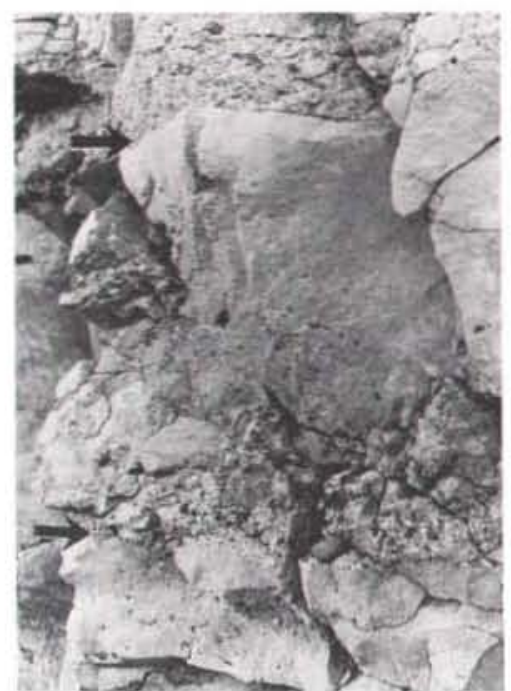

Fig. 13. Channels in Rigi Member, western Kuhn $\varnothing$. Conglomerates at the base of channels (indicated by arrows) grade rapidly into medium sandstone. Midfan association.

described by using the Bouma sequence (e.g. Walker \& Mutti, 1973; Ricci-Lucchi, 1975).

Having interpreted both subfacies as being deposited by either high density turbidity currents or by flows transitional to liquefied flows (and possibly to grain flows) it is still necessary to explain their pronounced differences. The mudstone layer which in many cases lines the bases of the wide, shallow channels of subfacies 7 a suggests that there was a considerable time lapse between erosion of the channels and deposition of the channel fill. Furthermore the flows from which the sandstone was deposited had no erosive effect since the mudstone layer is undisturbed. In some cases the channel was totally abandoned and filled with mudstone (section

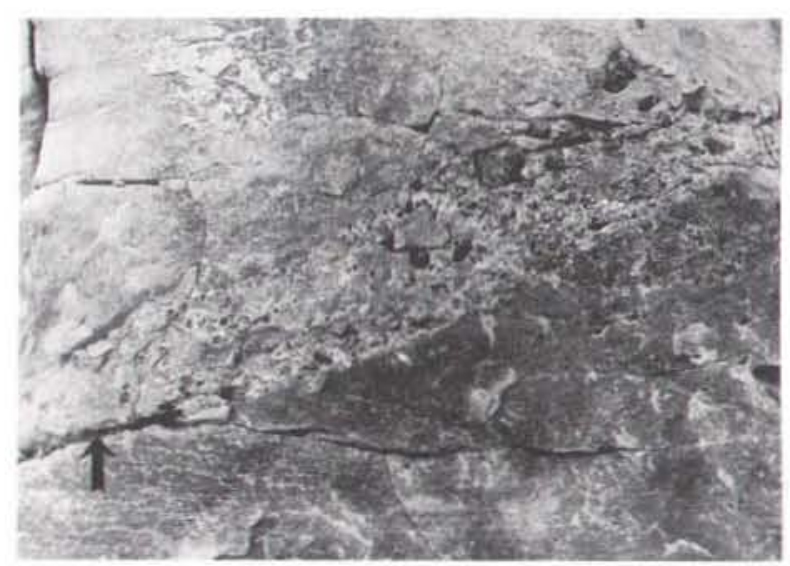

Fig. 14. Detail of channel wall. Clasts at base of well graded channel fill comprise mainly worn belemnites. Rigi Member. western Kuhn $\varnothing$. Midfan association. 
Fig. 15. Structureless conglomerate with clast of mudstone reworked. Rigi Member, Niesen, north Wollaston Forland. Inner fan channel association.

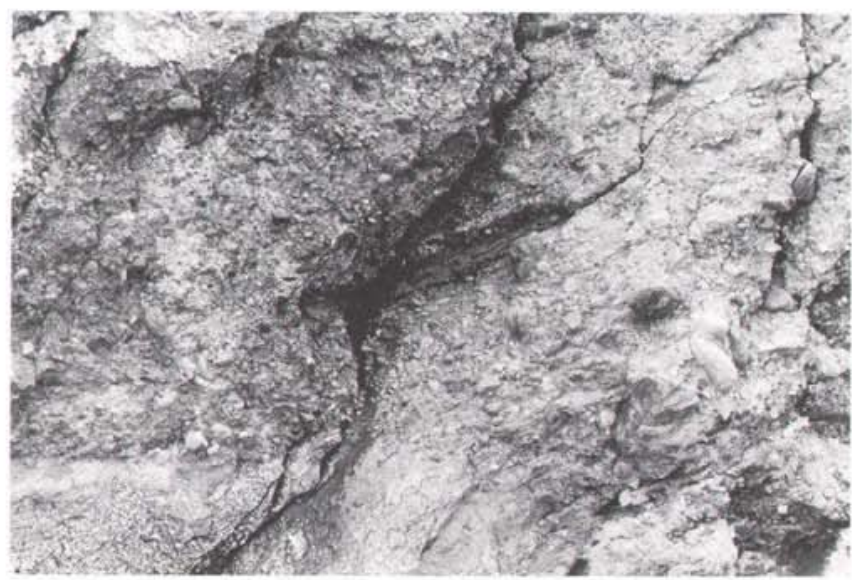

34, Appendix). In many cases the flows depositing the coarser, strongly channelled subfacies $7 \mathrm{~b}$ were probably the erosive agent. There are never signs of deposition of finer-grained sediments on the channel floors and there is always a very high correlation between axial channel directions and direction of pebble imbrication in the channel fill. The consistent upwards decrease in bed thickness and grain size so clearly demonstrated by the channel illustrated in figs $10-12$ points towards a decrease in current velocity or sediment load for successive episodes. A decrease in velocity may be a direct result of the gradual filling of the channel. The differences between the two subfacies are consequently thought to be the result of deposition on different parts of a depositional system characterized by a number of factors: different degrees of channelling, fluctuating sediment supply, slope angle, and frequency of sediment flow.

Fig. 16. Angular semi-lithified clast of Laugeites Ravine (?) mudstone showing well developed lamination in composite conglomerate-sandstone sequence. Rigi Member, Niesen. Scale on pebble at base of photograph $=1 \mathrm{~cm}$. Inner fan channel association.

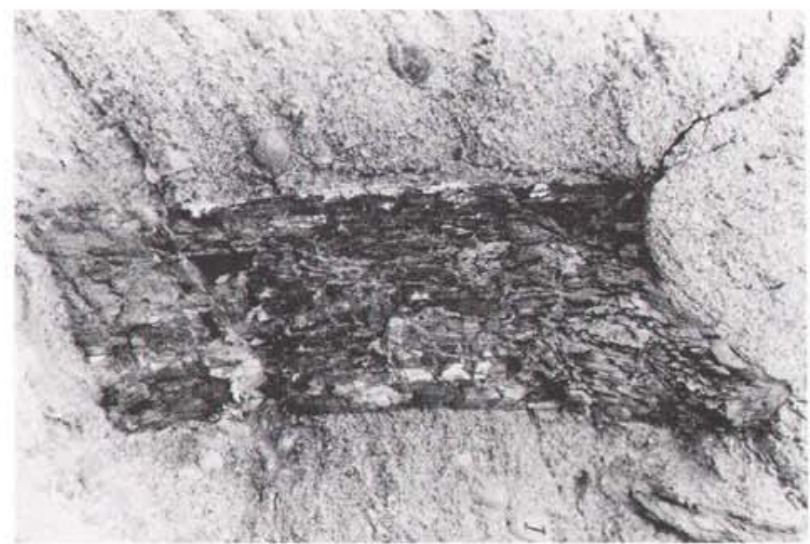




\section{Conglomerates}

General description

This facies is mainly composed of cobbles and boulders in a matrix of coarse pebbly sand. Both matrix and clast supported varieties occur. The beds are either non-graded, normal graded, or inverse-to-normal graded. The clasts are orientated either randomly, horizontally, or imbricated with long axes showing unimodal orientation.

The facies is characterized by complex channelling although some beds have a horizontal non-erosive base. Sedimentary structures produced by traction currents, such as cross-bedding, are practically absent.

Marine fossils (ammonites, belemnites, Buchia) occur throughout the facies.

\section{General interpretation}

The facies was deposited in a fully marine environment. The presence of different types of grading, clast-long-axis imbrication and alignment or disorganized fabric, and the almost total lack of stratification such as cross-bedding or other structures indicative of traction current transport of a bed load suggest sediment gravity flow as a transporting mechanism.

\section{Subfacies}

In the facies analysis of the conglomerates the most important criteria are grain size, nature and percentage of matrix, bed thickness, bedding regularity, presence or absence of channels, internal structures of grading and finally palaeoecological indicators (compare Walker, 1973).

The conglomerates of facies 8 show wide ranges in all these features and practically all combinations occur so that a very large number of facies could be created. On the other hand all combinations seem to form a continuum with gradual transitions from one variety to the next. The disorganized, non-graded conglomerates occur both as matrix and clast supported beds and are intimately interbedded with and pass laterally into organized (graded and/or imbricated) conglomerates. The transporting mechanisms of the organized and disorganized beds are therefore not thought to be fundamentally different. Rather it is possible that the relative importance of one or more of the clast supporting factors repeatedly changed during transport and deposition, thus giving rise to different fabric and grading combinations.

The sediments are therefore grouped together in one facies and are interpreted in more detail as a series of subfacies. 
Fig. 17. A. Scatter plot of maximum clast (MC) versus bed thickness. MC indicates the size of the largest clast in the bed. There is no correlation between the two parameters.

B. Scatter plot of maximum clast size (MCS) versus bed thickness. MCS is calculated as the average of 10 largest clasts after omitting the two largest. It is clear that there is no correlation between the two parameters.

C. Scatter plot of calculated maximum clast size (MCS) and the largest clast (MC). Up to a size of about $1 \mathrm{~m}$ of the largest clast there is a good linear correlation between the two parameters. This implies a relatively good sorting of the fraction above the sand grade. Higher values of $\mathrm{MC}$ are not correlated with higher MCS values and these clasts are clearly outsized.
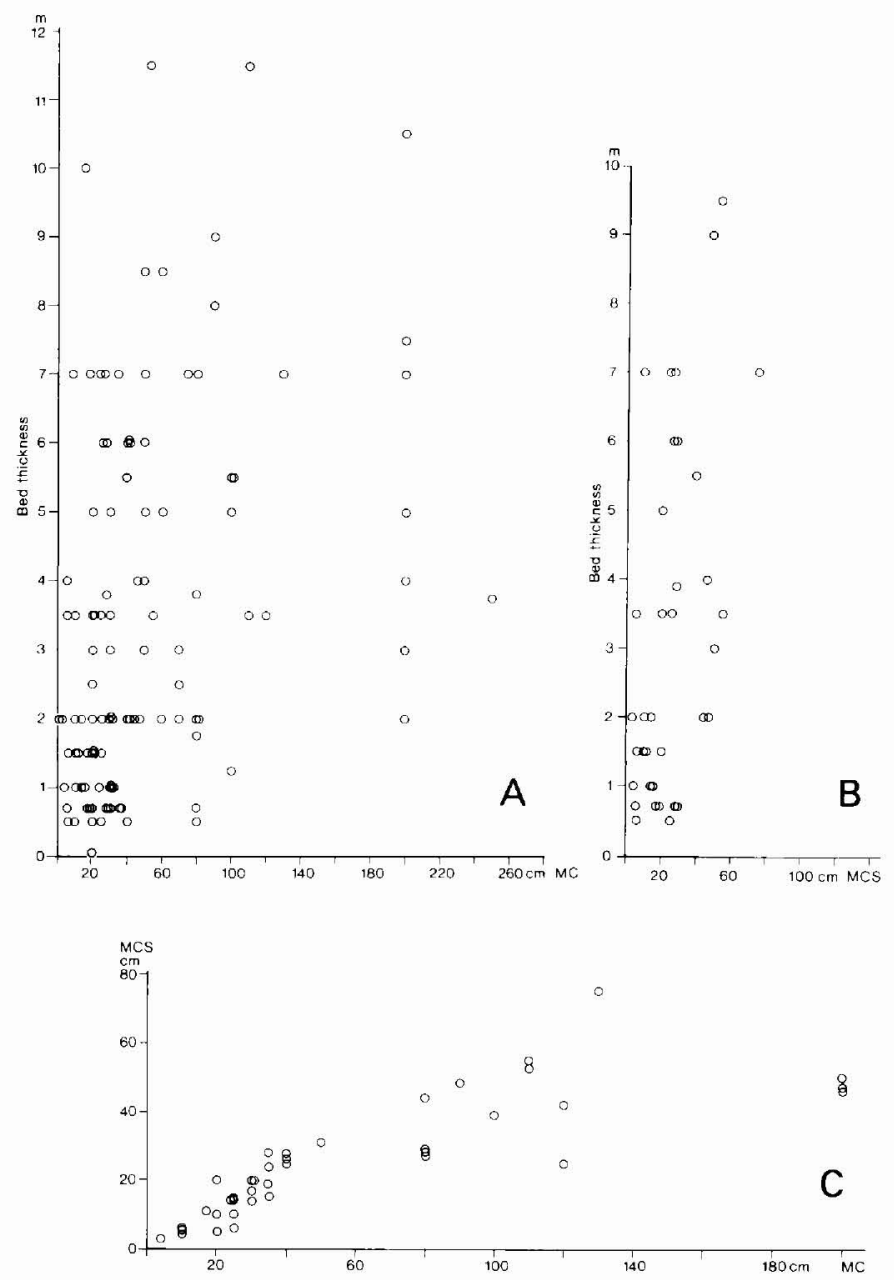

Clast size and shape. The conglomerates are dominantly very coarse cobble or boulder conglomerates. Pebble conglomerates are mainly restricted to the basal parts of the channelled sandstones of facies 7. The size of the largest clast $=\mathrm{MC}$ (open circles in the logs; Appendix), has been measured in the majority of beds, and the maximum clast size $=$ MCS (average of the ten largest clasts after omitting the two largest) has been calculated for some of the sections (black dots).

MC varies in diameter from 8 to $250 \mathrm{~cm}$, with diameters between 5 and $80 \mathrm{~cm}$ being the most common (fig. 17A). Blocks of the size 20-30 m have been observed in the field (see also Maync, 1947). MCS varies between 3 and $80 \mathrm{~cm}$ with 10 to 30 $\mathrm{cm}$ being the most common (fig. 17B). There is a fairly good correlation between 


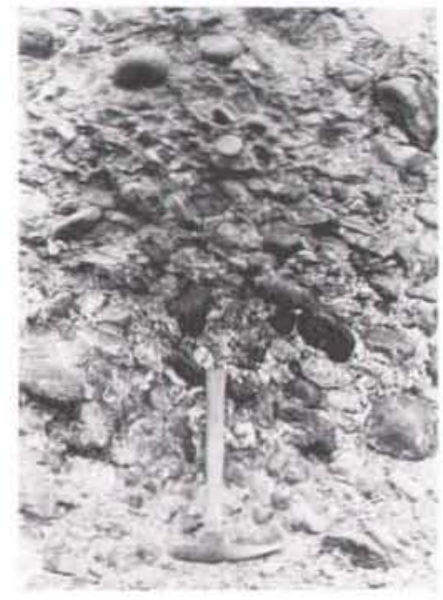

Fig. 18. Imbricated conglomerate with very little matrix. Clasts comprise mainly well rounded quartzites. Rigi Member, section 15, Niesen, north Wollaston Forland. Inner fan channel association.

MC and MCS except for the clasts above $1 \mathrm{~m}$ in diameter, which are clearly outsized (fig. 17C). This suggests a fairly good sorting of the coarsest fraction above the coarse sand fraction.

The clasts are normally well rounded but the degree of rounding appears, to a large extent, to be dependant on the source rock. Clasts composed of vein quartz dominate the conglomerates and are almost always very well rounded and tend to be equidimensional (fig. 18), whereas clasts of foliated gneisses have rounded, tabular shapes (figs 19-20). Clasts originating from gneisses and garnet amphibolites showing a distinct lineation are correspondingly rod shaped.

Nature and percentage of matrix. The matrix in the conglomerates invariably consists of very coarse poorly sorted sandstone with very litte ( $<1$ per cent) supposedly primary clay matrix. A fine-grained pseudomatrix composed of deformed phyllosilicates may occur. Sand grains in the matrix are angular to subangular and are composed mainly of quartz, plagioclase, microcline, rock fragments, mica and fragments of carbonate shells. The sandstone matrix can be classified as a litharenite or feldspathic litharenite after Folk (1968).

The pebble (clast) percentage has been roughly estimated in the field using Clifton's (1973) measure for pebble segregation, where 90-100 per cent describes an openwork conglomerate, 70-90 per cent a clast supported conglomerate with some matrix, 50-70 per cent a matrix supported conglomerate with 50 to 70 per cent clasts etc.

Six per cent of the beds measured for pebble segregation belong to the $90-100$ per cent class, 59 per cent to the $70-90$ per cent class, 26 per cent to the $50-70$ per cent class, 2 per cent to the $30-50$ per cent class, 1 per cent to the $10-30$ per cent class and 6 per cent to the $0-10$ per cent class (fig. 21). In sum 65 per cent of the 94 beds are clast supported and 35 per cent are matrix supported. 

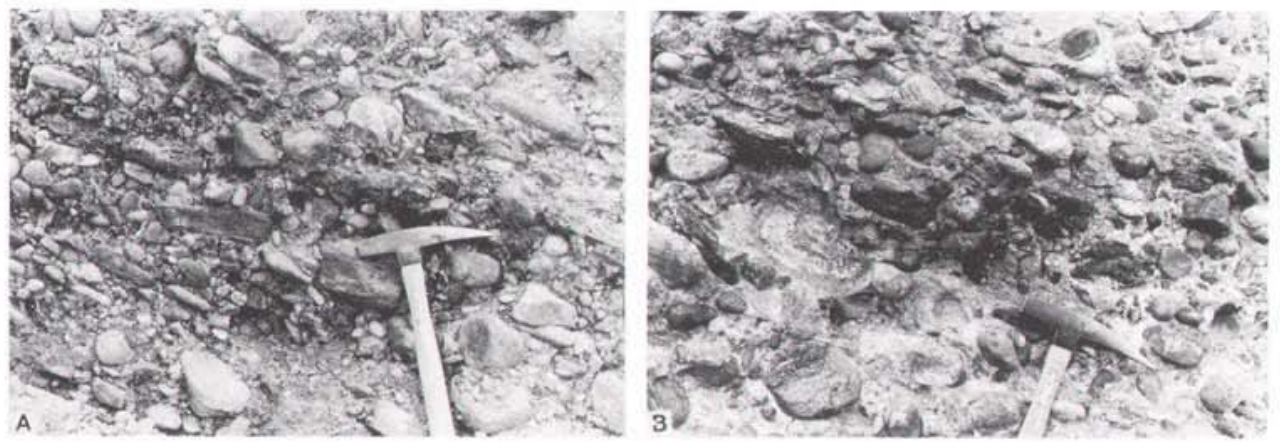

Fig. 19. A. Imbricated conglomerate dominated by flat, elongated clasts of well foliated gneisses. Section 15, Rigi Member, Niesen, north Wollaston Forland. Note slight grading. Inner fan channel association.

B. Extremely well developed imbricated conglomerate with flat elongated clasts of gneisses. Rigi Member, Niesen, north Wollaston Forland. Inner fan channel association.

Clast fabric. The clasts are either randomly orientated ( 34 per cent of conglomerate beds), or long axes are horizontally aligned parallel to flow (11 per cent), or the long axes are parallel to flow and imbricated with their long axes dipping upstream (55 per cent). All three fabric types are common and only one case has been observed where the channel fill clasts (rounded belemnite fragments) were orientated transverse to the channel axis and therefore probably to flow. The matrix percentage is commonly thought to be of critical importance in the interpretation of the transporting process of a conglomerate (e.g. Hampton, 1975). Matrix percentage is therefore plotted against the three different clast fabrics on fig. 21 . The number of observations for $90-100$ per cent and $0-10$ per cent clasts are too small to be of any significant value, whereas the $70-90$ per cent and $50-70$ per cent class

Fig. 20. Imbricated matrix rich conglomerate from top part of channel on fig. 11. Rigi Member, Palnatokes Bjerg. Proximal midfan association.

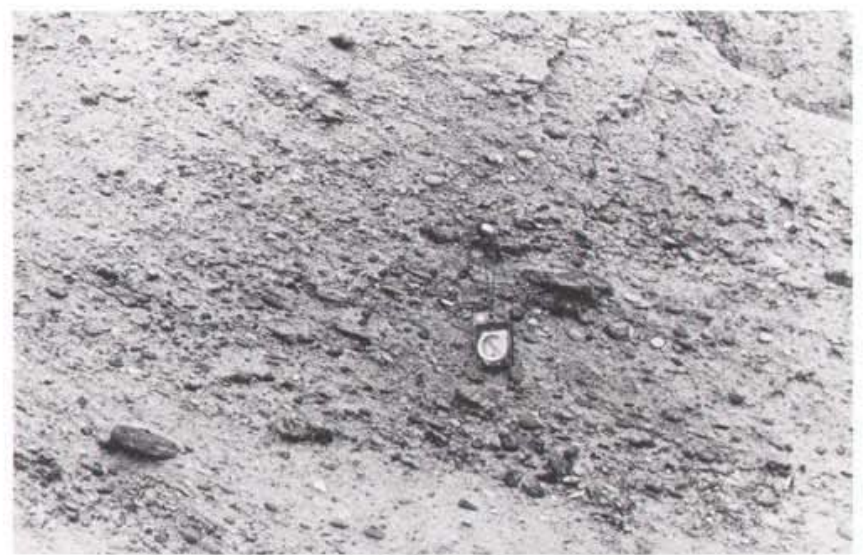


contain a total of 79 observations. The two classes show remarkably similar relative proportions for imbricated, horizontal and disorganized fabric in both clast and matrix supported conglomerates and the same general picture appears from the plot of all fabric observations (fig. 21). It can therefore be concluded that there is no significant correlation between matrix percentage and clast fabric in the present case. This somewhat unexpected result might be explained in terms of the extremely coarse-grained nature of the sandstone matrix and the very small amount of clay in the matrix.

Presence or absence of grading. Almost half of the beds are non-graded (49 per cent of beds). Among the graded beds four general types of grading are recognized (fig. 22) : (1) Weak grading of only the topmost part of the bed (22 per cent); (2) uniform grading from base to top of the bed (14 per cent); (3) inverse to normal grading ( 9 per cent); and (4) strong grading throughout the bed ending with total disappearance of clasts coarser than sand in the upper half of the bed (6 per cent).

The first four types of grading are mainly of the 'coarse-tail' type of grading (Middleton, 1967) with an upwards decrease in mean grain size of the coarsest fraction, accompanied by a much less pronounced grading of the finer fractions. The last type of grading is of the 'distribution type' in which all percentiles of the size distribution change upwards (Middleton, 1967, 1970).

In fig. 22 (lower left) each type of grading is furthermore subdivided into imbricated, horizontal or disorganized clast fabric, and it appears clearly from the diagram that there is no significant correlation between type of grading and a specific fabric. The relative importance of each fabric is roughly the same for each type of grading.

In fig. 23 the total number of combinations between clast/matrix support, type of grading and fabric is shown ranked after frequency of occurrence. Non-graded imbricated beds are the most common combination and constitute 31 per cent of the clast supported beds and 30 per cent of the matrix supported beds. There is no pronounced difference between the order of ranking for the two groups. The sum total scheme includes a number of beds where matrix content has not been recorded, but again the ranked sequence corresponds well to the ranking for both clast and matrix supported conglomerates.

It was concluded above that there was no significant correlation between matrix percentage and clast fabric, and this conclusion can now be extended to include the lack of significant correlation between type of grading and fabric. This, in addition to the lack of correlation between bed thickness and maximum clast size as discussed below shows clearly the difficulty of defining distinct facies (or subfacies) types for the present conglomerates.

Only the beds which are strongly graded from conglomerate to sandstone can immediately be distinguished from the remaining conglomerates. They have al- 

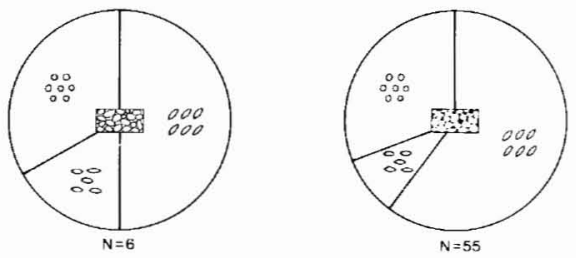

Fig. 21. Circle diagrams showing the relative proportion of the three different types of texture in clast supported conglomerates (upper), matrix supported conglomerates (middle row) and in all conglomerates measured for pebble segregation. (The actual clast percentage is shown in the appendix). The lower right circle includes 44 beds not measured for matrix content. It is remarkable that the relative proportion of texture types is roughly similar for the clast supported and the matrix supported conglomerates (compare $\mathrm{N}=55$ with $\mathrm{N}=$ $24)$. This suggests that in the present case the matrix content played a minor role for the development of a specific texture.

Fig. 22. The upper three circles show the relative proportion of non-graded, weakly graded, strongly graded, inverse to normal graded conglomerates, and conglomerates grading into sandstone. The three circles correspond in a clockwise direction to conglomerates with disorganized, imbricated or horizontal clast fabric. Note that the different types of grading occur in the same relative abundance in both imbricated and non-imbricated conglomerates. The circle in the lower right shows the sum of the three first circles, whereas the circle in the lower left corner includes 44 measurements which were not investigated for relative matrix content. In this circle each sector is subdivided to show the proportion of imbricated to horizontal to non-orientated clasts. This proportion is practically identical for each type of grading.

Consequently there is no correlation between type of texture and type of grading.
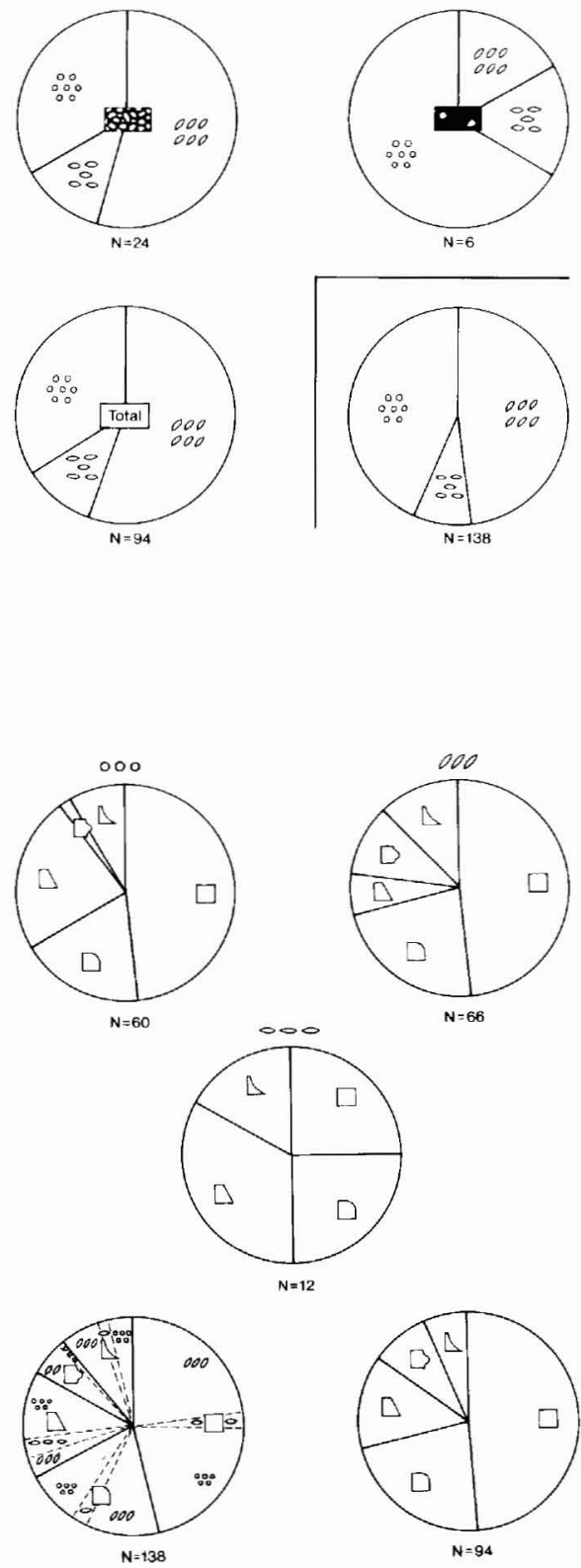


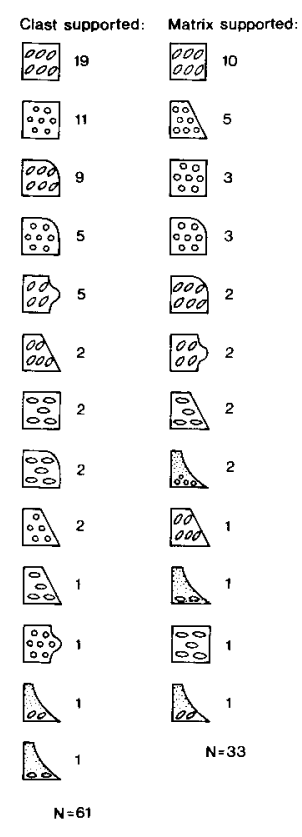

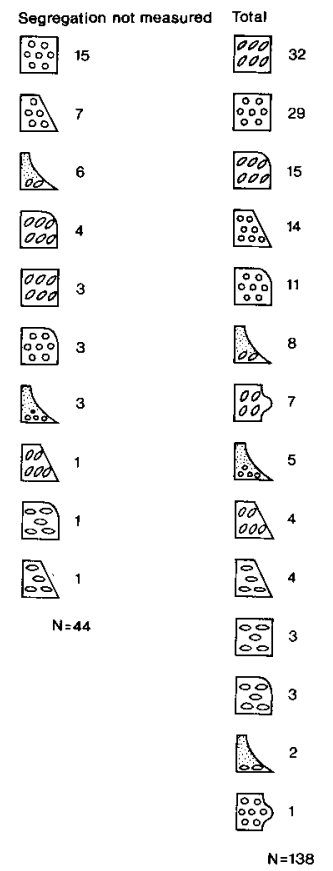

Fig. 23. Ranking of all possible texture - grading type combinations for clast supported and matrix supported conglomerates respectively. Note that the rank order is roughly the same for the two groups.

ready been treated as an end member of facies 7 (graded sandstones deposited in channels) and will therefore not be considered further here.

One clear tendency appears, however, from analysing the ranked frequency diagram (fig. 23); non-graded beds are by far the most common (52 per cent) and are followed in abundance by weakly graded ( 24 per cent), strongly graded (18 per cent) and inverse-to-normal graded ( 7 per cent). The conglomerates grading into sandstones have been excluded before calculating the percentages. Within each of the above groups the different fabric types occupy approximately the same proportion, except for the inverse-to-normal graded beds which are mainly imbricated (figs 22-23).

Bedding regularity, presence or absence of channels. The base of the conglomerates may be horizontal or weakly undulating without signs of erosion, or it may even be very strongly channelled. Channelling may be simple or it may be of a very complex nature showing repeated erosion and filling resulting in all gradations between well-defined symmetrical channels and a network of small wedge shaped remnants of channel fills. 
Bed thickness. Following Bluck (1967) several authors have emphasized the importance of measuring bed thickness in conglomerates, especially with reference to the plotting of a bed thickness versus maximum clast size diagram (Steel, 1974). In the present case, where conglomerates are strongly channelled and lenticular, the original thickness of most beds are likely to have been larger than now. The lack of correlation (fig. 17) in this instance might, therefore, be expected to be due to a range of apparent, (smaller) bed thicknesses. This is not the case here, however, since in comparison with published MCS/Bed thickness relationships (e.g. Bluck, 1967; Steel, 1974) the bed thicknesses here are too high, for given values of MCS. This, in return, suggests that here there was either additional factors contributing to the lack of a competence/capacity relationship, or that the bed was not deposited by 'freezing' of a whole flow but rather that sedimentation, although rapid, occurs gradually from the base of the bed upwards.

The conglomerates often contain small sandstone filled channel-shaped lenses without any signs of a break in conglomerate sedimentation at the level of the top of the channel sandstone (see e.g. section 155, Appendix). The maximum thickness of a conglomerate bed with such subordinate sandstone intercalations is about 45 $\mathrm{m}$ (section 45, Appendix). In some locations there is an extremely complex interbedding of vaguely defined sandstone and conglomerate lenses which renders discussion of bed thickness meaningless.

Fossil content. All the conglomerates contain randomly distributed marine fossils, often in abundance. The faunas are usually badly preserved and of very low diversity, as normal benthic elements are absent except for buchiid bivalves. The fauna comprises ammonites, Buchia, and belemnites. Carbonized plant fragments are very common. Trace fossils have not been observed.

In the following the general features of the conglomerates as described above form the basis for the definition of seven subfacies $(\mathrm{a}-\mathrm{g})$ :

\section{8a. Non-graded, matrix supported, disorganized conglomerate}

\section{Description}

The matrix is coarse, pebbly sandstone with a clay content generally below 1 per cent. The subfacies comprises 2.2 per cent of measured beds (but see below under 8b) and is otherwise characterized by the features listed in the heading (fig. 24).

\section{Interpretation}

The absence of an organized fabric and of grading suggests that the matrix possessed enough strength to support the clasts and that the facies was deposited by 


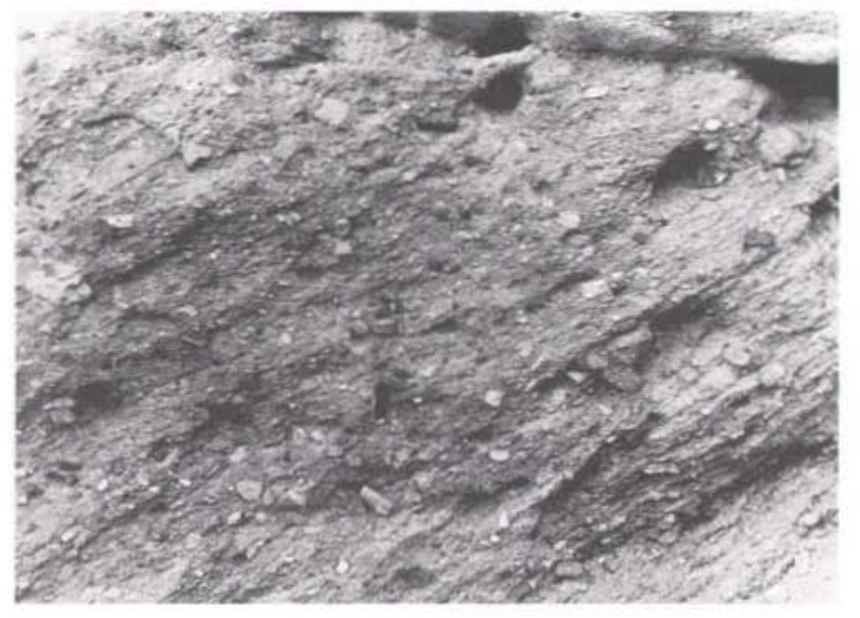

Fig. 24. Matrix supported conglomerate of the Rigi Member. The matrix is a coarse pebbly sandstone which is strongly jointed from upper right to lower left. Section 44, Clavering 0,450 $\mathrm{m}$ altitude.

freezing of subaqueous debris flows. A very low clay content is not unusual in debris flows (Middleton \& Hampton, 1976) but matrix strength was probably not the only supporting mechanism. The density difference between the coarse sand matrix and the clasts was only slight thus increasing the buoyancy. Fluid mixed into the flow at the base may have reduced the effective density of the debris flow and increased the possibility for clast collisions. The dispersive pressure arising from the clast interactions aided strength and buoyancy in supporting the grains but lack of inverse grading and imbrication suggests that it did not play an important role.

The subfacies is thus interpreted as being deposited from sandy debris flows transitional to density-modified grain flows.

\section{8b. Non-graded, clast supported, disorganized conglomerate}

\section{Description}

This subfacies is closely related to subfacies $8 \mathrm{a}$ but differs in being clast supported (fig. 25). It comprises 8.0 per cent of the measured beds, but subfacies $8 \mathrm{a}$ and 8 b comprise together 21 per cent of the studied beds, but only 2.2 per cent +8.0 per cent were measured for matrix content.

\section{Interpretation}

Dispersive pressure caused by clast interaction was probably the main supporting mechanism aided by matrix strength and buoyancy. This suggests that the subfacies was deposited by density-modified grain flows transitional to sandy debris flows. 
Fig. 25. Matrix rich conglomerate of the Young Sund Member; Valanginian. Clasts comprise iron stained well rounded quartzites and large blocks of reworked sediment. Hammer rests on reworked concretion of penecontemporaneous Albrechts Bugt Member. Cardiocerasdal south slope. Inner fan lobe association.

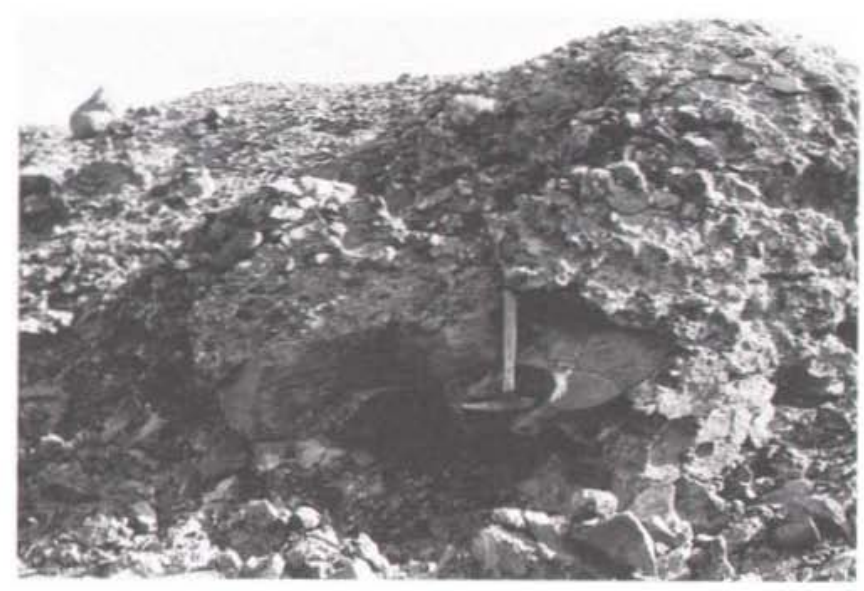

8c. Non-graded imbricated conglomerate

Description

This subfacies comprises both matrix and clast supported conglomerates with imbricated or horizontal, unimodal clast orientation (figs 19-20). It contains 25.4 per cent of measured beds.

\section{Interpretation}

The preferred long axis orientation parallel to flow shows that the clasts were relatively free to move with respect to each other, did not roll along the bed, and were supported above the bed (Walker, 1975b). According to Rees (1968) the imbrication is a result of tilting of the principal clast axis during collision of clasts. The fabric formed either in a highly turbulent flow or in a non-turbulent debris flow. In the first case the clasts were supported above the bed by fluid turbulence, or dispersive pressure, or both (Middleton \& Hampton, 1976; Davies \& Walker, 1974). In the second case the clasts were buoyed by the matrix viscosity, dispersive pressure, and in some cases shear strength and high density of the debris.

In the matrix supported end-member of this subfacies the clast collisions were not elastic, but the momentum was transferred through the matrix, and the clasts were probably supported both by matrix strength and dispersive pressure with the latter factor being of relatively greater importance than in the former subfacies $8 \mathrm{~b}$. Grading and imbrication are well known from debris flow deposits (Johnson, 1970; Bull, 1972; Walker, 1975a) and as mentioned by Hampton (1975) "most real 
debris flows are probably combination debris flow-grain flows" in the sense of Middleton \& Hampton (1973).

The matrix supported end-member of subfacies $8 \mathrm{c}$ passes gradually into the clast supported end-member. This type of conglomerate and its more organized associates were interpreted as a result of highly turbulent flow by Davies \& Walker (1974), because of the abundance of normal and inverse graded bedding, stratification, preferred clast fabric and scarcity of matrix. In the present case stratification is absent and there is an intimate interbedding between otherwise identical clast and matrix supported conglomerates. The scarcity of matrix in itself therefore seems not to be of fundamental importance in the present case. Water introduced into the flow particularly at the base may decrease the viscosity and increase the possibility for free clast movements, collisions, and development of a preferred fabric development (Walker, 1975a). In a debris flow a rigid plug of some thickness always exists (Johnson, 1970; Hampton, 1975). The plug boundaries migrate continuously and shear may thereby be obtained at every level of the flow resulting in the development of a parallel clast fabric (Hampton, 1975).

The fabric of the present subfacies suggests that collisions of clasts produced dispersive pressure that contributed to the support of clasts and this mechanism was probably the most important supporting mechanism during transport, with matrix strength playing a subordinate role. Poorly sorted clasts can comprise more than 95 per cent of the volume of debris yet having essentially no influence on the gross strength of the debris. Thus, large blocks can be suspended by debris with low strength (Rodine \& Johnson, 1976).

The subfacies is thus interpreted as deposited from density-modified, viscous or inertial grain flows. The viscous flows are transitional to sandy debris flows.

\section{8d. Graded conglomerates}

\section{Description}

The subfacies consists of graded conglomerates without an organized clast fabric (18.1 per cent of the measured beds). In some beds it is only the topmost part of the bed which shows a 'coarse-tail' grading (only the clasts of the largest size are absent). This type passes into beds showing uniform grading from base to top. The grading is of the distribution type, but is most pronounced for the grades above the sand fraction.

\section{Interpretation}

The occurrence of grading implies that clasts were able to move freely with respect to each other and that there was a lateral segregation of clast sizes within the current (Walker, 1965). The grading of only the top part of a bed possibly 
indicates only a slight density separation where the largest clasts have sunk down from the highest part of the flow. This could be a result of downward migration of the rigid plug in a debris flow (Johnson, 1970; Hampton, 1975). When the plug reaches the bottom of the flow, deposition will occur, and as the grain sizes are coarser in the plug than in the zones of shear it is likely that the slightly finer grained top of the beds in question represents the zone above the plug. The lack of an organized clast fabric indicates that clast collisions have not played a major role as a supporting factor at the time of deposition. Fabric could probably be developed if the clasts were of a flat, disc like type - all other things being equal. Clasts with a large surface area could be supported by a relatively weak matrix (Hampton, 1975). In the present case this phenomenon has actually been observed in several beds. Parts of a bed containing mainly well rounded oval clasts of vein quartz show little or no fabric whereas immediately adjacent parts dominated by platy clasts of foliated gneiss show pronounced imbrication. Compare, for example the orientation of clasts of different shapes on figs 18-19.

The present subfacies $8 \mathrm{~d}$ is therefore interpreted as deposited from a sandy debris flow where some vertical and lateral clast segregation has taken place. Matrix strength and buoyancy were the dominant supporting mechanisms and dispersive pressure caused by clast collision played a subordinate role.

\section{8e. Graded, imbricated conglomerates}

\section{Description}

Subfacies $8 \mathrm{e}$ is intimately related to subfacies $8 \mathrm{~d}$. It comprises graded conglomerates possessing an imbricated or horizontal clast fabric (18.8 per cent of the recorded beds) (fig. 26).

\section{Interpretation}

The presence of grading shows that the flow was mature enough to have allowed the development of both vertical and lateral segregation of different clast sizes. Furthermore the imbrication indicates that the dispersive pressure played a dominant supportive role and, in matrix poor cases, possibly also fluid turbulence. In the matrix rich varieties matrix strength and buoyancy may also have played a role and it is known that imbrication can develop in natural debris flows.

\section{8f. Inverse-to-normally graded conglomerates}

\section{Description}

Imbricated clast fabric is normally well developed in this subfacies which comprises 5.8 per cent of the measured beds (fig. 27). 


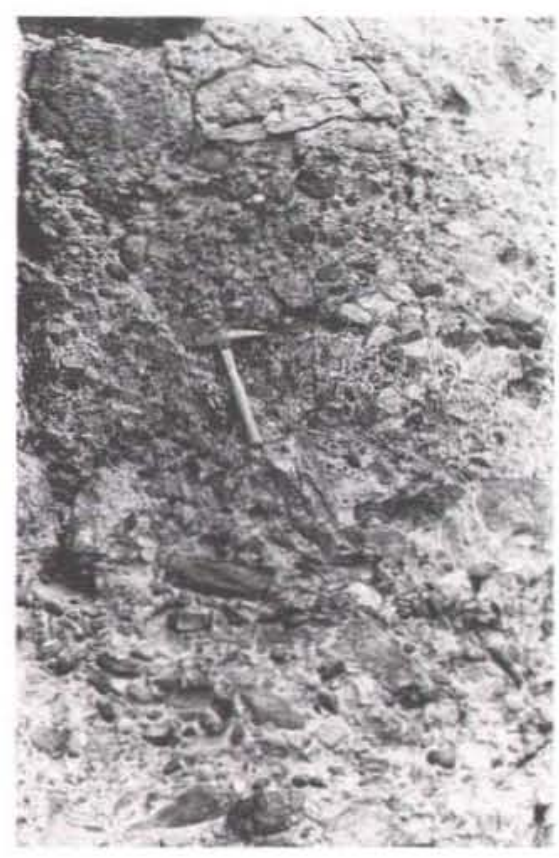

Fig. 26. Breccias transitional to conglomerates of the Rigi Member; Volgian-Ryazanian. Section 30, $355 \mathrm{~m}$ altitude (Appendix), north Wollaston Forland. Clasts comprise well foliated gneisses and mica schists. Note the imbrication, especially of the oblong angular clasts and the relatively large matrix content. Inner fan channel association.

\section{Interpretation}

The presence of inverse grading as well as imbrication implies a type of flow in which clasts are able to move freely with respect to each other. The grading points to lateral segregation of clast size within the flow. Furthermore, the presence of inverse grading is probably due to size sorting within a concentrated layer of clasts maintained above the bed by dispersive pressure (Bagnold, 1954). The applied

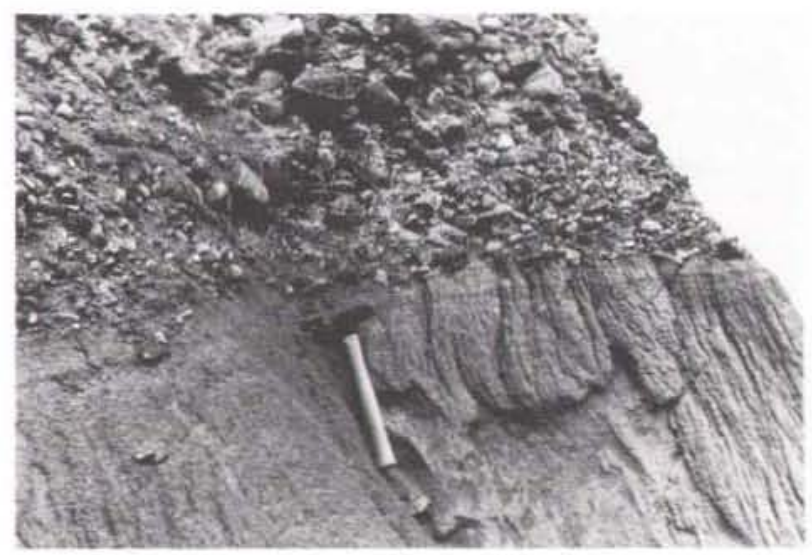

Fig. 27. Imbricated conglomerate overlying graded structureless sandstone. Rigi Member, section 152, Niesen, $199 \mathrm{~m}$ altitude. north Wollaston Forland. Note the inverse grading of the basal half metre of conglomerate, and the even contact to the sandstone. Inner fan channel association. 
Fig. 28. Channelled composite bedded conglomerates and sandstones adjacent to beds on section 50 at about 380-385 m altitude (Appendix). Width of section $2 \mathrm{~m}$. Note the very weak stratification outlined by diffuse oblique pebblyzonesin the upperwedge-shaped sandstone. Rigi Member, Palnatokes Bjerg, north Wollaston Forland. Transition between inner fan channel and midfan association.

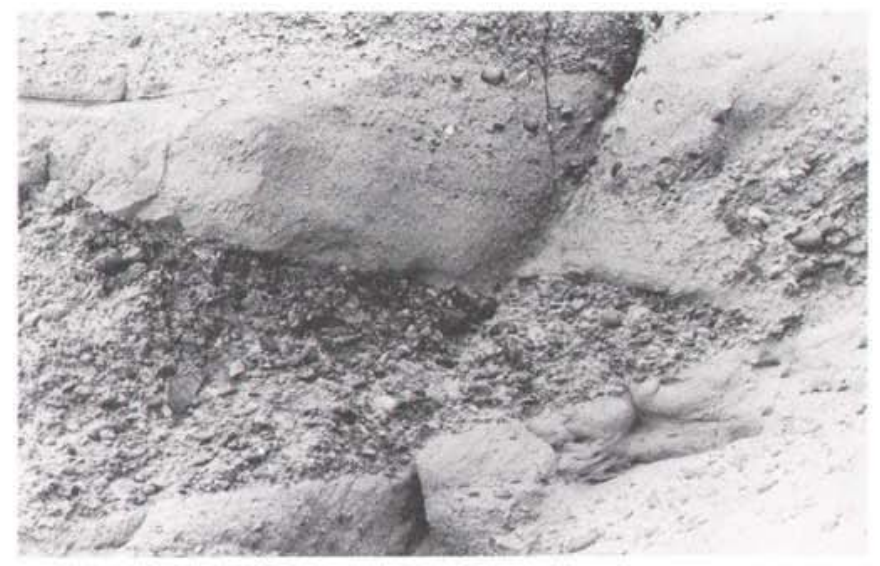

shear stress must be larger in order to maintain the dispersive pressure. According to Walker (1975b) this might imply a relationship between inverse grading, steep slopes, and proximal environments.

This subfacies is thus interpreted as deposited from inertial density-modified grain flows.

\section{8g. Composite conglomerates}

\section{Description}

This subfacies is different from the six preceding relatively simple subfacies in that beds are often structured in an extremely complex manner. The conglomerates contain more or less well defined internal, discontinuous layers and lenses of sandstone. The sandstones usually have a relatively flat upper surface whereas the lower surface is irregular and always convex downward. The sandstones may be graded or ungraded and sometimes contain isolated floating clasts. They may possess a vague stratification outlined by diffuse pebbly stringers (fig. 28). The conglomerates can in themselves be classified in the above subfacies as they are characterized by the same combinations of segregation, grading, and fabric (sections $15^{1}, 15^{4}, 15^{5}, 31,32,33,45,49,50$; Appendix). They differ from the other conglomerate subfacies $(8 \mathrm{a}-8 \mathrm{f})$ only in their content of sandstones. The interbedding of sandstones and conglomerates in the composite conglomerates varies from the occurrence of isolated simple thin sandstone lenses in thick conglomerates (e.g. section $15^{4}$, Appendix) to extremely complex interbedding. The latter type is practically impossible to measure in the normal detail. They appear to resemble the composite conglomerates described from Lower Ordovician rocks of Quebec by Hendry (1973), and there can be little doubt of their common mode of formation. 
Interpretation

The conglomerates are interpreted as having been deposited from sediment gravity flows where matrix strength and clast-interaction dispersive pressure were the dominant clast supportive factors. Following Hendry (1973 p. 135) the composite beds are believed to have resulted from progressive failure on a slope, producing a series of retrogressive flows, whereby successive pulses of mass-flowing coarse material were mobilized downslope, proceeded by successive failure in their headward portions. It is thus the mechanism of initiation of movement of the sediment mass, rather than a mechanism operating during transport of deposition that results in formation of the composite conglomerates. Deposition of each composite bed represents a relatively short time interval. If slumping took place in an area composed of alternating layers of conglomerates and sandstones (like the bulk of the Rigi Member) and if the transporting mechanisms were of the type outlined above for subfacies $8 \mathrm{a}-\mathrm{f}$, the character of the resulting deposit would mainly reflect the distance of transport and amount of mixing undergone by the original component beds. The sandstone lenses are thus interpreted in terms of redeposition of earlier proximal turbidites, grain or debris flow deposits. Thus although the sandstone parts of the composite conglomerates petrographically are identical to the 'proximal turbidites' and grain flows of facies 5-7 they are deposited by the same mechanisms as the conglomerates within which they are interlayered.

A miniature modern analogue was recently described by Carter (1975).

\section{Stratified pebble conglomerates}

\section{Description}

This final conglomeratic facies deviates from all the subfacies of facies 8 (conglomerates) in being finer grained and possessing stratification. Facies 9 comprises mainly fine to coarse pebble conglomerates with scattered floating larger clasts which only rarely reach a diameter of more than $10 \mathrm{~cm}$. The facies shows more or less well developed stratification outlined by layers of circular disc shaped quartzite pebbles with an average diameter of about $1 \mathrm{~cm}$ set in a matrix of coarse poorly sorted sandstone. Both the stratification and the attitude of the flat pebbles are horizontal. The individual pebble layers attain a thickness of a few centimetres and the layers can be traced up to 15-20 m laterally. The distance between the pebble layers varies from 5 to $50 \mathrm{~cm}$. The isolated larger clasts occur randomly distributed or in layers one clast thick (fig. 29). They do not show imbrication but long axes tend to be arranged parallel to bedding. It is considered important that this facies contains the only large-scale, planar cross-bedded units found in the whole investigated sequence (figs 29-30). The facies appears to be close or identical to the crudely stratified fine to coarse pebbly conglomerate of Davies \& Walker (1974, fig. 10) and Walker (1975b). 
Fig. 29. Stratified pebble conglomerate overlain by horizontally laminated and small scale cross laminated sandstone with mud flasers. Rigi Member, section 44 (Appendix), Clavering Ø, altitude $380 \mathrm{~m}$.

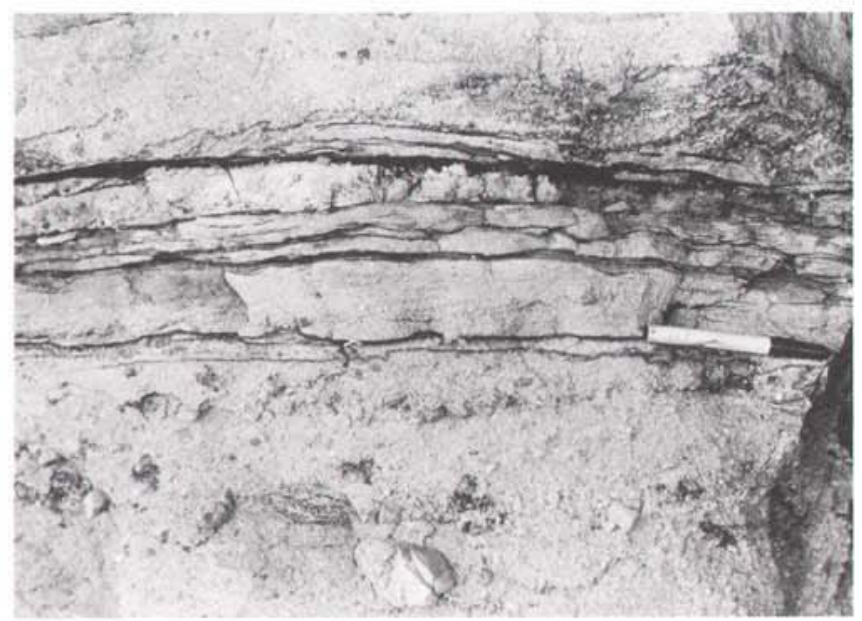

It dominates the Rigi Member in the coastal section (section $44^{1-3}$, Appendix) in Clavering $\varnothing$. In the Wollaston Forland-Kuhn $\varnothing$ area it occurs only sporadically, mainly in finer grained portions of the composite conglomerate subfacies $(8 \mathrm{~g})$.

\section{Interpretation}

Davies \& Walker (1974, p. 1212) described three types of (graded) stratified conglomerates. Their third type - "regular alternations of granule-rich and granule-poor sandstone layers" is similar to the present facies. They suggested that the granules were moving into their final position by bedload traction, but that the sand was deposited directly from suspension. The shear velocity required to initiate

Fig. 30. Horizontally laminated and faint current ripple laminated sandstone with mudstone flasers (at marker pen), overlain by planar cross-bedded pebbly sandstone. This is one out of a total of five cross-bedded layers found in all the measured sections. Rigi Member, section 44 (Appendix), Clavering $\varnothing$, altitude $380 \mathrm{~m}$.

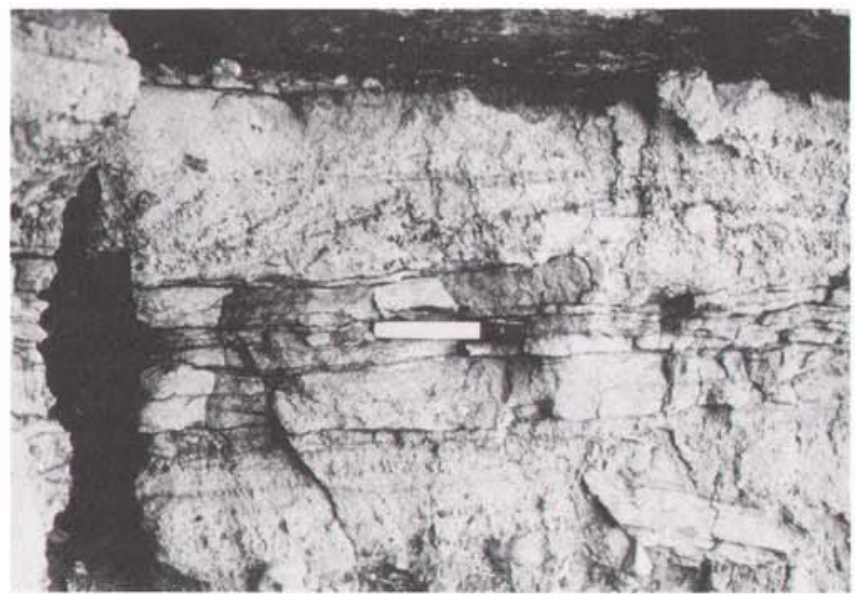

5 Bulletin nr. 128 
granule transport on the bed was calculated to be sufficient to maintain low concentrations of sand in suspension (Davies \& Walker, 1974, p. 1214). The alternation of sand and granule layers may therefore be due to fluctuating current velocities. Walker (1975b) estimated that a flow that can roll e.g. $2 \mathrm{~cm}$ pebbles on the bed can also maintain low concentrations of sand in suspension. Slight fluctuations in velocity could therefore form alternating layers of coarse sand and 2 centimetre-sized pebbles. The occurrence of interbedded cross-bedded sandstones deposited from migrating mega-ripples corresponds well with an interpretation for the facies involving bedload traction in contrast to the pure gravity flow transport envisaged for the earlier described sandstone facies.

\section{Breccias}

\section{Description}

This facies comprises coarse-grained breccias composed of clasts of a wide variety of metamorphic and igneous rocks. The breccias mainly occur in close proximity to the Dombjerg-Thomsen Land Fault (fig. 3). They display vaguely horizontal bedding or are structureless throughout. Clast size varies from a few centimetres to $20-30 \mathrm{~m}$, but generally the largest clasts have a diameter of $0.5-1 \mathrm{~m}$. Clasts comprise garnet mica schist, granite, amphibolite, gneiss, quartzite, rare basalt but practically no sedimentary rocks. Clasts are usually angular, but all transitions to well rounded clasts may be found, even within the same bed (figs 26, 31-33). The interfingering and lateral grading into conglomerates is pronounced. The matrix content is generally low to almost absent but a few cases of matrix supported breccias have, however, been observed. Breccias without matrix are mainly found in the western parts of the area immediately east of the bordering faults. The best section occurs in south-eastern Th. Thomsen Land where a strongly tilted sequence about $100 \mathrm{~m}$ in thickness rests on Caledonian basement. Matrix is totally absent in many horizons of this section resulting in very dense packing of the angular to slightly rounded clasts. The breccia displays an indistinct bedding with a bed thickness varying from $0.5-30 \mathrm{~m}$. Other sedimentary structures include slump structures associated with loading around and below boulders. At the top of the section there is often a tendency towards imbrication of elongated clasts. Where present, the matrix consists of a very coarse-grained pebbly sandstone or even crushed rock fragments formed by impact of surrounding boulders during deposition.

Outside Th. Thomsen Land the breccias mainly occur as thick isolated beds or groups of beds within the conglomerates. Imbrication is common where the clasts comprise elongated fragments of well foliated gneisses or mica schists. The conglomerates of the Valanginian Young Sund Member occasionally contain angular blocks of Upper Jurassic Bernbjerg mudstones and again the term breccia would be 
Fig. 31. Matrix rich breccia-conglomerate of the Young Sund Member dominated by large angular clasts of black reworked Bernbjerg mudstones. Clasts are lying subhorizontally, the apparent imbrication being a result of post-depositional tectonic tilting. Cardiocerasdal, south slope. Base of fault scarp slope transition to inner fan lobe association.

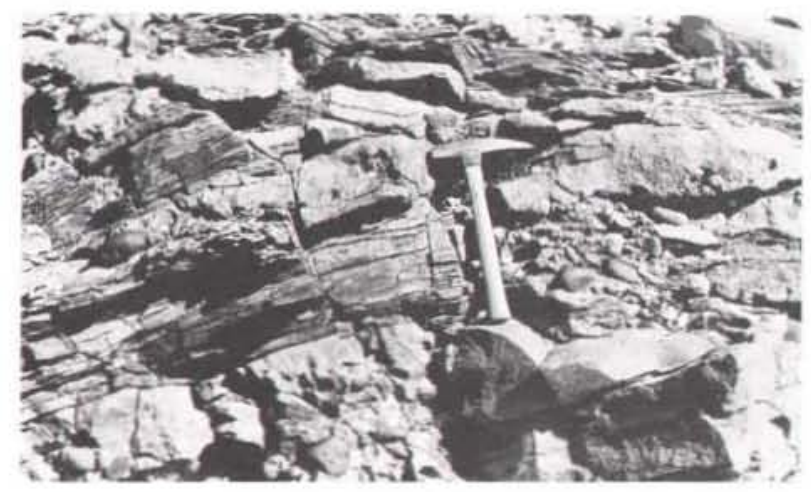

appropriate (fig. 31). Breccias interfingering with conglomerates show a faint bedding and always rest with a gentle, even or slightly undulating surface on the underlying sandstones or conglomerates. They are rarely found as fills in channels or other erosional structures.

The breccias invariably contain marine fossils such as belemnites or Buchia, but the fossils are always rare.

\section{Interpretation}

The breccias show some resemblance to wildflysch or sedimentary mélanges in being chaotic deposits with exotic blocks (see Hsü, 1974) but lack a sheared matrix. The ubiquitous occurrence of marine fossils even in sequences resting directly on Caledonian basement indicates a marine depositional environment. The very thick, structureless, chaotic breccias situated adjacent to the main faults were probably emplaced as submarine rock fall avalanches. It is clear that submarine deposition

Fig. 32. Chaotic breccia. Hammer to the lower right of the large boulder gives scale. Both angular and rounded boulders occur. They comprise mainly gneiss, granite, and quartzite. Base of fault scarp slope association. NW side of Palnatokes Bjerg, north Wollaston Forland. Rigi Member; Volgian-Ryazanian.

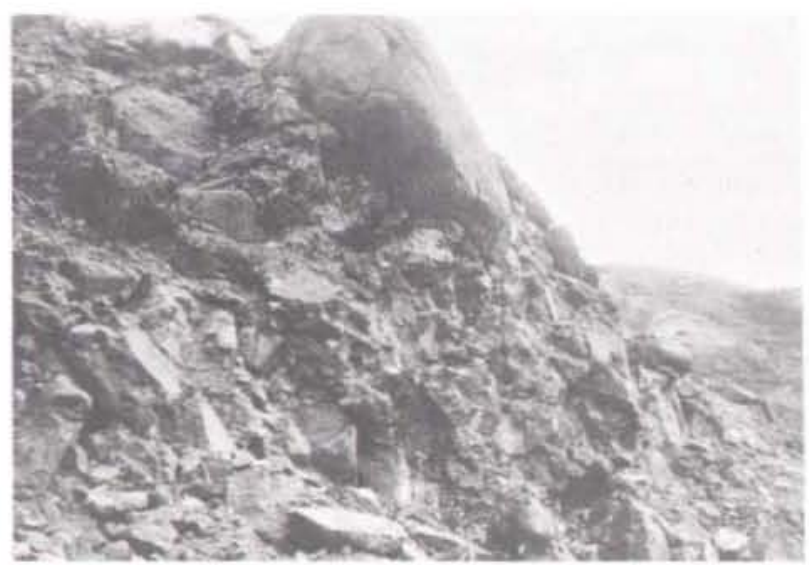




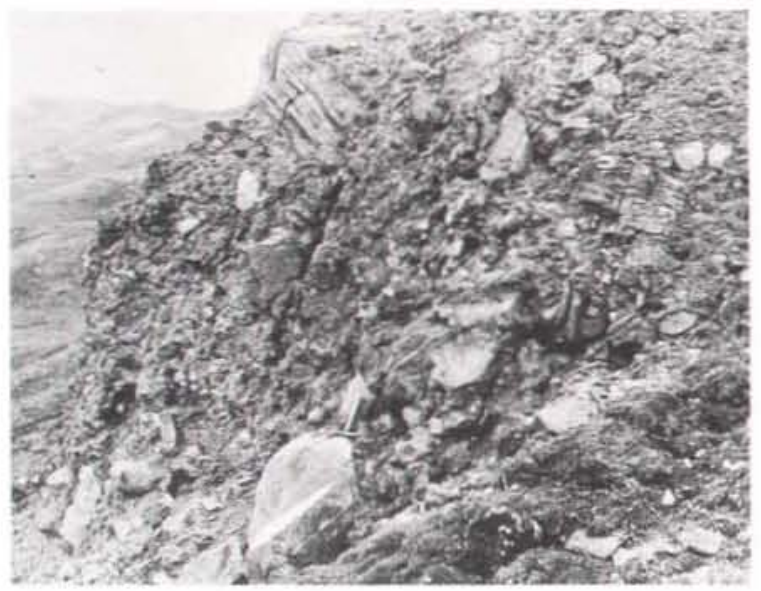

Fig. 33. Chaotic breccias of the Rigi Member, Volgian; Niesen about 100 $\mathrm{m}$ altitude, north Wollaston Forland showing complete lack of sorting. clast orientation and bedding. The dominant clasts are gneisses and $\mathrm{mi}-$ ca schists. The section is well exposed and gives a good impression of the nature of the breccias. Largest boulders have a diameter of about 2 $\mathrm{m}$. Hammer on block in foreground for scale. Base of fault scarp slope association.

and introduction of some matrix profoundly changes the characteristics of the rock fall avalanche. Depending on water content and on concentration and nature of matrix several mechanisms, such as grain interactions and matrix strength will be of varying importance in supporting the clasts in the gravity flow. In breccias with little or no matrix the supporting mechanism will be clast collisions. The clast supported breccias with some matrix probably underwent some dilution during the subaqueous transport, whereby the viscosity was decreased which again increased the possibility for free clast movement leading to the development of imbrication. In the few examples of matrix supported breccias the higher viscosity of the flows induced by matrix content might have been the most important supporting factor, although the low clay content of the matrix implies that clast collision also played a role in this case.

\section{Models of resedimented conglomerates}

Until recently only very few sequences of resedimented conglomerate have been adequately described and interpreted in terms of transportation and deposition mechanisms. As mentioned by Walker (1975a) this is probably due to the fact that most workers are not sure which aspects of the deposits should be measured and recorded. Because of the absence of a descriptive framework - or model - to guide field observations Davies \& Walker (1974) and Walker (1975a) attempted to establish a model. This model can be tested against our data which were collected before the model was published.

According to Walker (1975a) a sedimentological model should be a distillate from many different examples of rocks from different areas and of different ages. A 
model emphasizes the aspects that individual examples have in common and discriminates against the features of a more local nature. Furthermore, a general model can be used in three ways. First, the model can guide future observations. Second, it can be used as the basis for hydrodynamic interpretations. Thifd, it can be used to predict the geology of new areas given a minimal number of surface or subsurface data.

Following the notion of Pettijohn (1957) when he suggested the terms orthoand paraconglomerates, Walker \& Mutti (1973) and Walker (1975a) suggested that resedimented conglomerates first should be divided into clast and matrix supported types. The matrix supported conglomerates were not considered further. The clast supported conglomerates could be divided into two basic types - organized and disorganized, and the elements of organization were basically clast fabric, normal and (or) inverse graded bedding, and stratification.

Different combinations of these elements characterize the three resedimented conglomerate models proposed by Walker (1975b):

(1) Inverse-to-normally graded model, characterized by the association: inverse grading $\rightarrow$ normal grading $\rightarrow$ no stratification. This model is subdivided into a normal graded and an inverse-to-normally graded model by Walker (1976).

(2) Graded-stratified model characterized by the association: no inverse grading $\rightarrow$ normal grading $\rightarrow$ stratification.

(3) Disorganized-bed model characterized by the association: no inverse grading no normal grading - no stratification.

As demonstrated in the preceding section the matrix and clast supported conglomerates of the present study possessed roughly the same relative proportion of non-graded, and different types of graded beds (fig. 23). Furthermore, the different combinations of grading type and clast fabric occur in more or less the same relative abundance for both matrix and clast supported conglomerates (figs 21-22). Consequently there seems to be no strong a priori reasons to exclude matrix supported conglomerates from the model. The strong distinction between organized and disorganized conglomerates in the models seems also to be more of descriptive than conceptual importance. The same has been noted for beach gravels by Bluck (1967). In our conglomerates, non-graded beds without a developed fabric may rapidly develop an imbricated fabric when traced laterally. They may also show inverse grading at the base. All possible transitions of all parameters occur laterally or vertically in one bed. Matrix content varies greatly also - a bed may show matrix support in one part and clast support in another.

Thus the three models, except perhaps for the graded - stratified model, which is uncommon in the present case - occur in exactly the same setting, are complexly interbedded, and pass rapidly into each other both laterally and vertically in one bed. 
It can therefore be concluded that it is still necessary to operate with a purely descriptive model, as the models of Walker $(1975 \mathrm{~b}, 1976)$ do not seem to be satisfactory for all resedimented conglomerates.

Consequently Walker's model does not seem to fulfil any of his four points (1975a, p. 143): i.e. function as a norm with which other examples can be compared and contrasted; act as a framework and guide for future observations; form a basis for hydrodynamic interpretations; and be used to predict the geology of new areas.

The model does not function well in the basin analysis since it only seems to be valid in specific tectonic-sedimentologic settings.

The reason for the limited success of the Walker models is maybe due to the fact that practically identical conglomerates can be deposited from fundamentally different types of currents or flows in different tectonic settings.

However, the descriptive features on which Walker built his models seems to be sufficient for field studies of conglomerates, and an excellent review is given by Walker (1975a).

\section{Palaeocurrent patterns and provenance}

The palaeocurrents have been deduced from measurements of up-dip directions of long axes of imbricated clasts and channel axes.

All palaeocurrent data collected in measured sections are shown on the sections (Appendix). A total sum plot of all imbrication measurements is plotted as a palaeocurrent rose on fig. 34 . The pattern is strongly unimodal with a relatively low spread around the mean which is $74^{\circ}$. The mean calculated on the basis of estimates of the average direction of imbrication in whole beds is $86^{\circ}$. It is significant that the mean palaeocurrent direction is almost precisely at a right angle to the Dombjerg Fault, which formed the margin of the Kuppel Block depositional basin (fig. 34). In detail, the northernmost localities in Wollaston Forland include a number of beds which show transport from north-west at a right angle to NE-SW trending border faults between Wollaston Forland and Th. Thomsen Land (fig. 34). These measurements include both channel axes and imbrication. On western Kuhn $\varnothing$ a few channel axes are again running at a right angle to the dominantly NNE-SSW and NNW-SSE trending Thomsen Land Fault system. Whereas the overall palaeocurrent system is simple in showing a unidirectional transport to the east, the individual sections often display a systematic change from, for example, eastwards at the base to north-eastwards at the top (sections 49-50, Appendix). The same trend can be followed in several relatively closely situated sections and is consequently not just a local deviation, but is of more general importance.

The only transport pattern which does not fit into the simple eastwards transport pattern was collected in the only 'classic turbidite' sequence in the area. It is located 


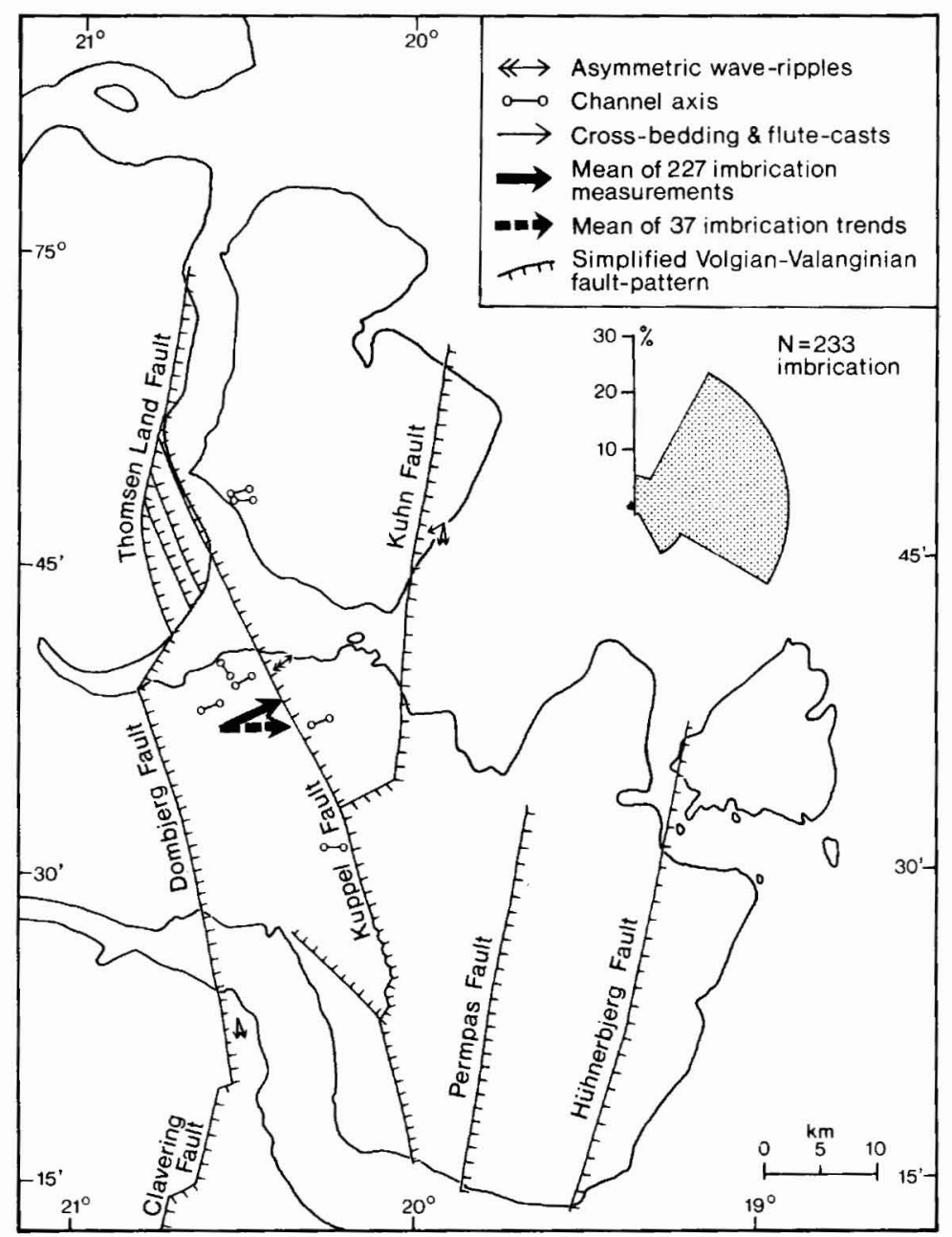

Fig. 34. Palaeocurrent map of the Wollaston Forland area. Note that the average of all measures of clast long axis orientation is at an almost right angle to the border fault. The two fat arrows placed approximately centrally in the area are where the measurements were made.

in eastern Kuhn $\varnothing$ in the Permpas Block (fig. 3). This sequence was described in detail by Surlyk \& Clemmensen (1975a) and a few measurements indicate transport from north and north-east.

The position and nature of the source area can only be the old Caledonian mainland to the west bordered by the Clavering-Dombjerg-Thomsen Land Fault system. This is clearly witnessed by the very simple palaeocurrent system and from observations on the nature of the clasts, supported by a few pebble counts. The 
dominant clasts are vein quartzites, foliated gneisses, amphibolites, mica schists, rare basalts, and in some localities, also rip-up clasts of sandstones and mudstones. The intraformational clasts are especially numerous in the Young Sund Member, which in addition is characterized by the high degree of clast rounding and iron-staining of the clasts.

A pebble count of 100 pebbles from one square metre from section 49 (Appendix) at $368 \mathrm{~m}$ altitude gave the following result: quartzite 40, gneiss 39, garnet amphibolite 11 , granite 7 , biotite gneiss 3 , greenschists 2 . This clast composition is fairly typical for most of the conglomerates, although the more matrix rich varieties often contain a relatively larger proportion of clasts which are more susceptible to mechanical wear than quartzite, e.g. mica schists and strongly foliated biotite gneisses. The area, today exposed west of the Clavering Fault is, according to the geological map of Koch \& Haller (1971), mainly composed of quartzitic schist to gneiss, bedded quartzite to gneiss, migmatite gneiss, granite, amphibolite, pegmatite and quartz veins.

West of the Dombjerg and Thomsen Land Faults the exposed rocks comprise mainly migmatite gneiss, amphibolite and pegmatite.

According to Leedal (1952) the metamorphism of the igneous rocks and sediments of the area west of the faults occurred in two main phases, in part overlapping. Firstly they were folded and altered under strong shearing stress and at moderately high temperature. During this period of metamorphism they were transformed into crystalline schists and gneisses with well defined directional structures. Shortly after, or possibly in part contemporaneous, the schists and gneisses were invaded by granitic material accompanied by a marked increase in the temperature and a corresponding decrease in the shearing stress. The gneisses and schists unaffected by regional injection belong to the amphibolite facies, typical assemblages being pelitic and psammitic schists, calcareous schists, intermediate and acid gneisses and amphibolite. The gneisses and schist of the injection complex belong to the amphibolite facies (sillimanite-almandine subfacies).

The crystalline rocks have been divided into a basement series of mainly orthogneisses, and a younger series including orthoschists, paraschists and gneisses. Leedal (1952, p. 19) suggests correlation of the younger series with the metasediments of the Kejser Franz Josephs Fjord region. He implies they correspond to the lower levels of the Eleonore Bay Group and therefore reached their present condition during the Caledonian orogeny, but more recent investigations suggest that many features previously regarded as Caledonian are in part due to pre-Caledonian orogenic events (Henriksen \& Higgins, 1976). Unmetamorphosed Eleonore Bay sediments have not been found preserved in the area west of the fault zone.

There is thus a pronounced resemblance between the composition of the crystalline bedrock west of the faults and the composition of the clasts of the conglomerates. 
The predominance of very quartz rich metamorphic rocks in the source area is characteristic and corresponds well with the dominance of quartzitic clasts in the conglomerates.

There is consequently no reason to suspect that the crystalline rocks exposed in these areas today are different from those exposed at the time of the late Jurassic-early Cretaceous tectonism and the associated deposition of the rocks described in the present paper.

Palaeozoic coarse-clastic molasse sediments which could have formed another type of source only occur in western Clavering $\varnothing$ (Carboniferous molasse). They are thought to have been primarily absent from the remainder of the area, which probably formed a high area during Devonian-Carboniferous molasse deposition.

As demonstrated above, the Caledonian terrain to the west formed the source region for the sediments deposited in the fault controlled basins. Coarse clastic debris was transported to the east away from the fault scarps of the Clavering-Dombjerg-Thomsen Land Fault zone by different types of sediment gravity flows. The boulders and cobbles of the conglomerates are, however, well rounded, and it is therefore a question if the rounding is multicyclic, and if it took place in the littoral zone before the down-slope transport. Kelling (1976) concluded from studying clast shapes in proximal channelled facies of early Palaeozoic submarine canyon-fan complexes, Eocene flysch facies and modern north-west Atlantic submarine canyons that the clasts tended to obtain fluvial rather than littoral aspect. This property was thought to have resulted from sorting rather than inheritance and thus suggests that the mass-transport mechanisms responsible for both 'organized' and 'disorganized' rudites are effective shape-sorting agencies. Kelling further suggested that the spuriously high roundness values of many intrabasinal pebbles and cobbles provide evidence for the abrasive potential of mass-flow mechanisms operating on poorly lithified constituents. The suggestions of Kelling are generally supported in this study although no systematic analysis on clast shapes has been undertaken. The proximal occurrence of highly angular clasts forming thick breccia beds, the intimate interbedding of the breccias with conglomerates composed of well rounded clasts, the proximal-distal increase in roundness of clasts all suggest that the rounding took place during transport first in high gradient fluvial streams leading directly from the fault scarp, and, more important, during sediment gravity flows down the submarine slope.

\section{Facies Associations}

The individual facies described in the preceding chapter have been described only in terms of depositional processes and except for a few remarks nothing has been inferred about the depositional environment. Analyses of associations of facies, their sequential arrangement and spatial distribution make it possible, how- 
ever, to reconstruct the palaeoenvironment and to develop facies models (see e.g. Walker, 1976).

A facies association is defined following Collinson (1969) as a group of facies genetically related to one another and which have some environmental significance.

The marine nature of all the described facies, the lack of any shallow water indicators, the mechanisms of transport and deposition being sediment gravity flows, the almost total lack of cross-bedding generated by bottom currents, the dominance of very coarse grain sizes, the unidirectional palaeocurrents and the abundance of channelling all point towards deposition in a submarine fan environment.

In recent years many workers have reported on the general geometry, facies distribution and growth pattern of modern and ancient submarine fans (e.g. Walker \& Mutti, 1973; Nelson \& Kulm, 1973; Normark, 1974; Nelson \& Nilsen, 1974; Mutti, 1974; Whitaker, 1974; Walker, 1976; to mention some of the more recent reviews). A general model for sedimentation on submarine fans has been established for modern fans by Normark $(1970,1974)$ and for ancient fans by Mutti \& Ghibaudo (1972) and Mutti (1974). The model includes a nearshore point source of clastic material, a submarine canyon or channel through which the clastics are funnelled down a slope, a submarine fan and a basin plain. The submarine fan comprises an inner, a middle and an outer fan. The inner (upper) fan is characterized by deep, submarine valleys or channels often with levees generally filled with coarse-grained sediments within a mudstone sequence. The middle fan has numerous, rather shallow channels filled with relatively coarse-grained material within a thin bedded fine-grained sandstone and siltstone sequence. Normark (1970) placed the depositional lobes in the midfan or suprafan. Ricci-Lucchi (1975) maintained a division whereby the lobes are included in the outer fan because of its definition as a non-channelled area. This is misleading in the light of recent studies of modern fans (e.g. Damuth \& Kumar, 1975) as the apparent absence of channels on the outer fan seems to be due to limited resolving power of the applied techniques such as the deep-tow and narrow-beam echo sounder. According to Normark (1974) sands are commonest on the suprafan or midfan. The sand is deposited in a channel-distributary system. The outer fan is free of major topographic relief and coarse-grained sediments and associated channelling become less evident and are replaced by increasingly fine-grained well-bedded deposits.

\section{Methods}

In the following a number of facies associations are established by an analysis of recurrent facies combinations in the measured sections.

Major trends in vertical facies sequences are thus analysed and the sequences are further- 
more investigated for thinning and/or fining upwards cycles, and thickening and/or coarsening upwards cycles (sensu Ricci-Lucchi, 1975).

The associations are described and interpreted according to their depositional environment. Finally the sum of facies associations is compared to the submarine fan model described above.

All beds in each section have been placed in a specific facies. In this connection it must be emphasized that in some of the sections $\left(5,14^{3}, 15^{3}, 17 \mathrm{a}, 17 \mathrm{~b}^{1-2}\right.$; Appendix) graded sandstones are placed in facies 7 (graded channelled sandstones) although the sections show that the beds have horizontal, parallel boundaries, and thus should have been referred to facies 5 (graded sandstones with subhorizontal base). This discrepancy is due, however, to the sections in question being measured in narrow creeks where it was impossible to observe lateral thinning of beds within the section. The occurrence of channelling is in these cases estimated from examination of very closely situated small exposures adjacent to the main section.

After grouping all beds into different facies, the total thickness of each facies is calculated as a percentage of the whole section and plotted as a histogram for each section. Closer examination of the histograms reveals that most are dominated by one to three facies types and that these facies occur in recurrent combinations in almost all sections. Thus a number of facies associations can be distinguished on the basis of the histograms.

Another approach is to investigate the sections for recurrent facies sequences. In each section the facies sequence is written out and the number of transitions from one facies to another is counted for all sections (fig. 35). This analysis clearly reveals that relatively few facies transitions dominate in all sections. Fig. 35 shows that the most important transitions are $7-7,8-7,7-8,7-4,4-7,7-1,1-7$ and $8-8$. These transitions constitute more than 50 per cent of the observed transitions. $7-7$ and $8-8$ represent amalgamated sandstones and conglomerates respectively, whereas 7-4, 4-7, 1-7 and 7-1 represent interbedded 'proximal turbidites' and layers of mudstones. 8-7 and 7-8 are interbedded conglomerates and 'proximal turbidites'. It has not been possible to find any clear end-members in a series of transitions as in river deposits, where a cycle begins with a scoured surface, is overlain by a lag conglomerate followed by generally upwards fining cross-bedded and parallel laminated beds (e.g. Cant \& Walker, 1976). In the present case a mudstone layer can form the end-member of a graded turbidite; but it also occurs as a drape direct on the floor of the channel. It is, therefore, not possible to state that regular 1-7-1-7-1 transitions in a sequence correspond to a series of 7-1 events. Rather, each section comprises one or two spatially distinct relatively uniform associations of facies in which the individual facies are randomly interbedded.

The analyses for sequential facies patterns thus give about the same results as those picked out by the histograms, namely that each facies tends to be associated with only a few other facies in recurrent associations.

The two formations described in the present paper, the Lindemans Bugt Formation and the Palnatokes Bjerg Formation are treated under separate headings since they are composed of different facies associations which seem to signify somewhat different tectonic-oceanographic settings, although they both are thought to be the results of deposition on submarine fans. 


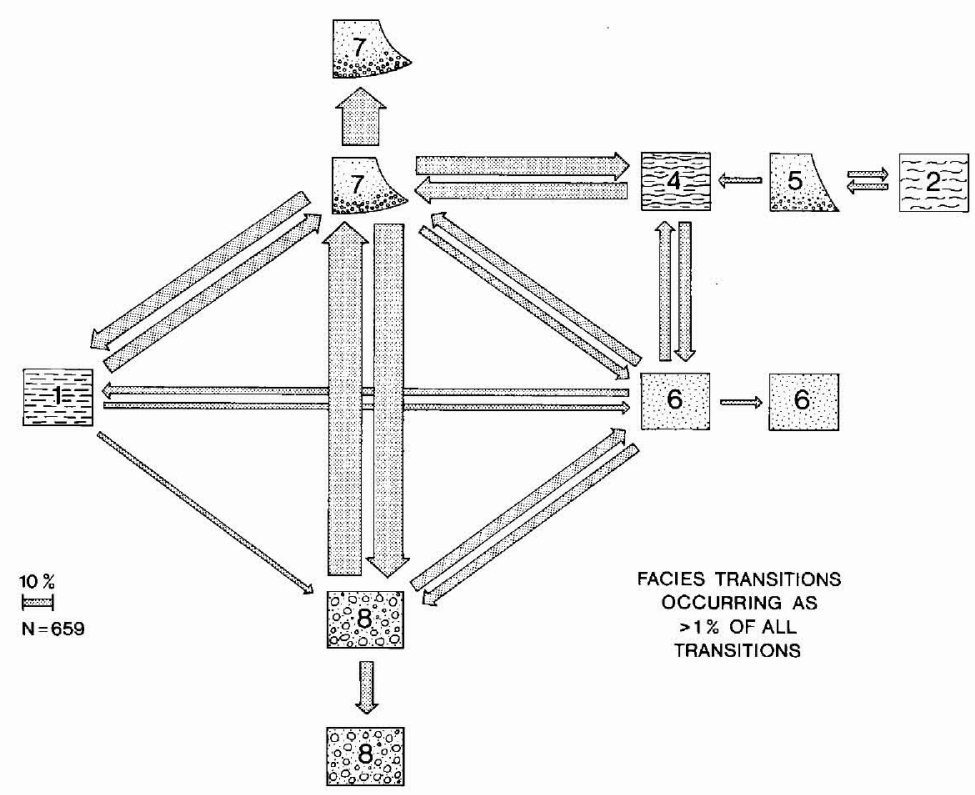

Fig. 35. Scheme showing facies transitions for all measured sections. The numbers and ornamentation are the same as used in the text and in the sections.

\section{Facies associations of the Lindemans Bugt Formation}

Eight facies associations $(a-h)$ are recognized in the Lindemansbugt and Palnatokes Bjerg Formations. Two of the associations ( $a$ and $b$ ) occur in both formations, whereas the remaining six associations of the Lindemans Bugt Formation are number $a, b, d, h$, and those of the Palnatokes Bjerg Formation $a, b, e, f, g$. The facies association $c$ occurs only on Clavering $\varnothing$ (section 44, Appendix) in an isolated fault block out of contact with other associations and is therefore treated separately.

\section{a. Base of fault scarp slope association}

\section{Description}

This facies association is restricted to the area immediately adjacent to the main bordering Dombjerg-Thomsen Land Fault. It comprises sediments belonging to facies 8 (conglomerates) and facies 10 (breccias) and is often characterized by the presence of very large angular clasts, lack of channelling, and scarcity of matrix. The rocks are extremely badly sorted and are disorganized. The individual units are either exposed as very thick, completely chaotic beds (figs 32-33) or form more 
continuous beds only a few metres thick, which seem to have been deposited as more or less horizontal units.

The association is exposed on scattered localities in western Wollaston Forland, where it is interbedded with rocks belonging to the following facies association $(b-$ Inner fan channel and lobe association). The best example is, however, found on the south-eastern corner of Th. Thomsen Land, where a thick strongly tilted sequence of very coarse-grained, bedded breccias rests direct on the Caledonian basement.

The association shows no systematic vertical sequences.

\section{Interpretation}

The disorganized nature of the association, its proximal position, the lack of channelling and the occurrence of marine fossils suggest deposition as submarine rockfalls and rockfall avalanches at the base of the partly submarine Dombjerg-Thomsen Land fault scarp. The blocks fell almost vertically direct from the fault scarp and spread out over the sea bottom. The type of movement was elastic (Dott, 1963). According to Mudge (1965) subaerial rockfalls result in lateral avalanches having a length of up to 10 times the distance of the vertical fall. Primary inclined bedding indicative of the formation of submarine talus slopes has not been observed.

\section{b. Inner fan channel and lobe association}

\section{Description}

This association occurs in a proximal situation in an up to $15 \mathrm{~km}$ broad belt parallel to the fault zone. It is strongly dominated by conglomerates (facies 8), interbedded with graded sandstones deposited in channels (facies 7) and, less commonly, with structureless non-graded sandstones (facies 6). Interlaminated mudstone and fine sandstone (facies 4 ) occur as thin units between many of the coarser beds but are volumetrically unimportant.

The association is characterized by strong channelling which is often of extremely complex nature corresponding to repeated episodes of channel cutting and filling (figs 36-39). The channel floors may be regular and more or less symmetrical or extremely irregular. Some examples of very irregular contacts between conglomerates have been observed which do not seem to have been the results of channel erosion. In these cases the individual beds have a primary convex-upwards upper boundary.

The conglomerates comprise all subfacies of facies 8 , and graded/non-graded, imbricated/disorganized, matrix/clast supported conglomerates occur in random interbedding. There is, however, a strong numerical dominance of little or 

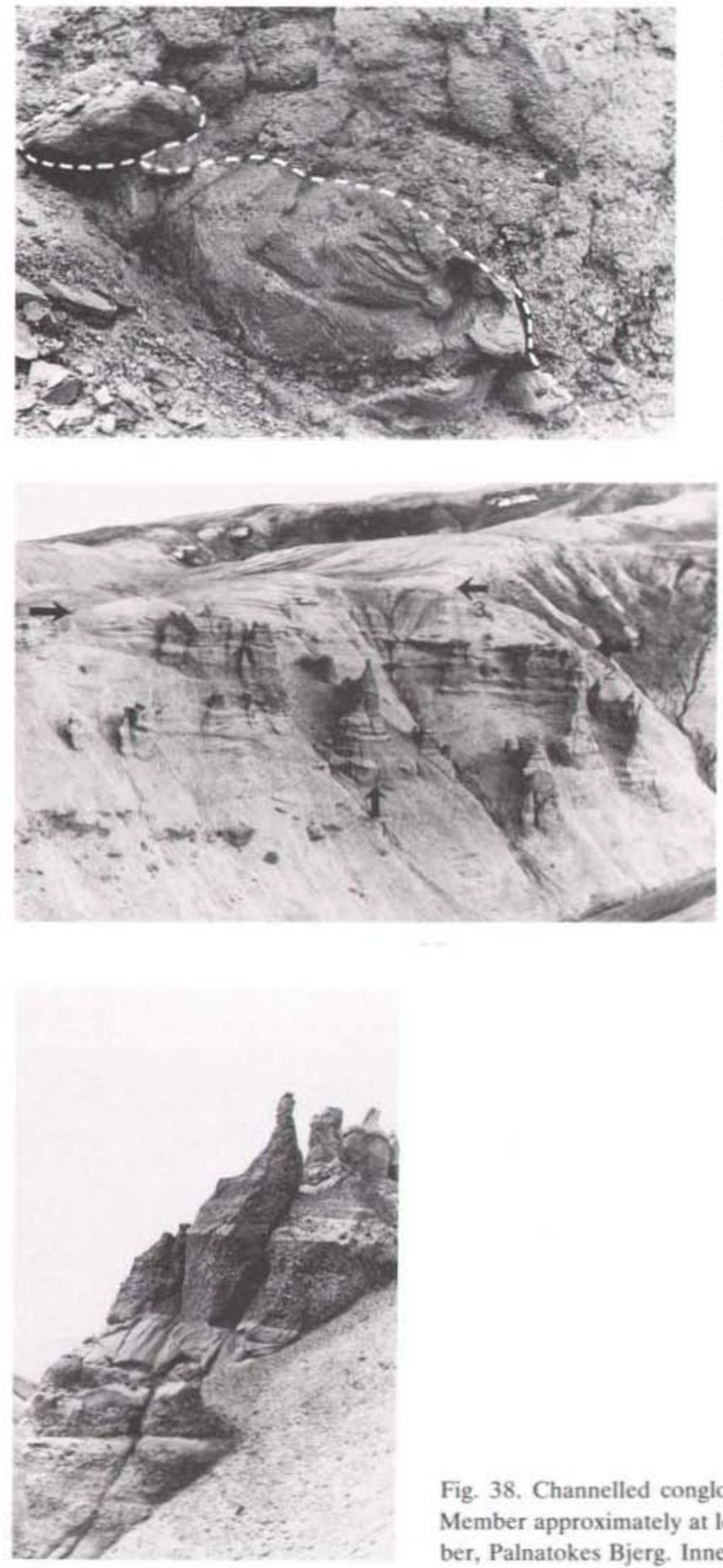

Fig. 36. Imbricated conglomerate deposited in irregular channel eroded in coarse pebbly sandstone. Boulder to the left is about $2 \mathrm{~m}$ wide. Channel wall is unusually irregular. Section $31,365 \mathrm{~m}$ altitude (Appendix). Rigi member, south side of east-west valley south of Niesen. Inner fan channel association.

Fig. 37. Location of section 49 (arrow 1) and 50. Strongly channelled conglomerates and coarse sandstones of the Rigi Member, inner fan channel association 2 (corresponding to the $390 \mathrm{~m}$ level in section 50) overlain at arrow 2 by wide flat channels filled with sandstones also of the Rigi Member, midfan association, and at arrow 3 (corresponding to the $416 \mathrm{~m}$ level in section 50 ) by horizontally laminated grey mudstones of the Albrechts Bugt Member, outer fan association, Palnatokes Bjerg. north Wollaston Forland. Photograph towards NE.

Fig. 38. Channelled conglomerates and sandstones of Rigi Member approximately at location of section 50. Rigi Member, Palnatokes Bjerg. Inner fan channel association. 


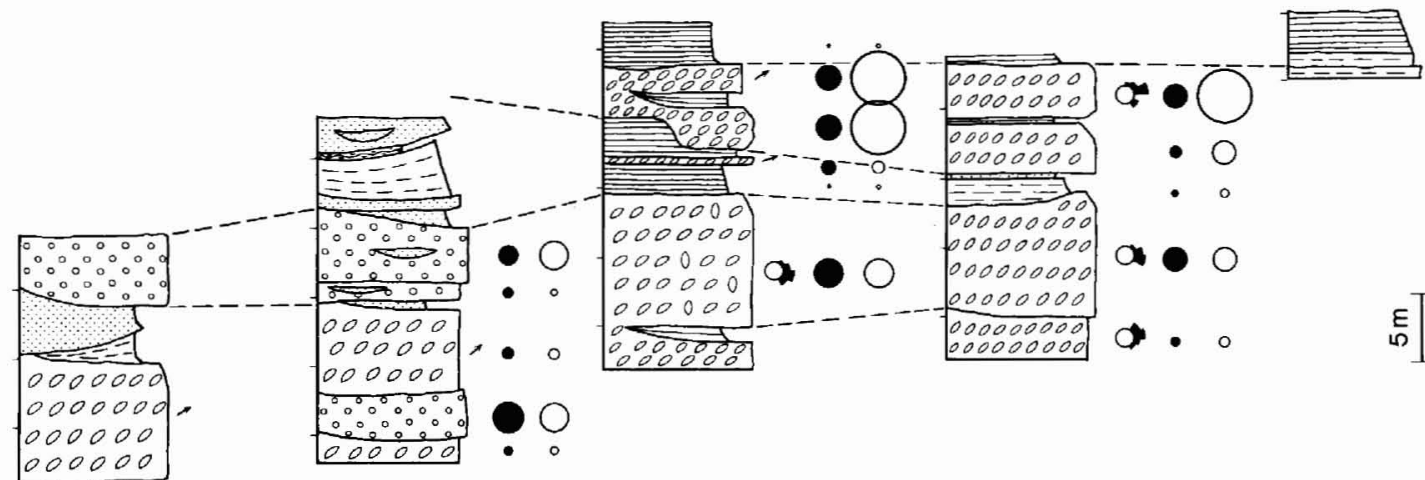

non-graded conglomerates followed with decreasing abundance by more and more strongly graded conglomerates (fig. 23). The composite conglomerates (facies $8 \mathrm{~g}$ ) form another conspicuous member of this association, although of relatively little volumetrical significance.

The individual facies of the association are either randomly interbedded without showing any sequential regularity or they occur in well developed fining-upwards cycles (sections 28, 46, 49, 50; Appendix), sensu Ricci-Lucchi $(1969,1975)$ and Mutti \& Ghibaudo (1972).

\section{Interpretation}

The proximal position, geometry, coarse grain size and ubiquitous occurrence of channelling suggest that the association was deposited in systems of channels on the inner part of a submarine fan. The convex-upwards beds and some of the composite conglomerates were, however, not laid down in channels although they occur intimately interbedded with the channelled facies. The convex-upwards upper boundaries are interpreted as primary depositional surfaces of steep-sided beds 
emplaced by sediment gravity flows where matrix strength played the dominant role as a clast supporting factor. The composite conglomerates may have a more sheet-like geometry. Both facies types were probably laid down as depositional lobes on the inner fan. Other flows possessed more erosive power and cut deep channels in earlier deposits.

The common occurrence of fining upwards cycles is interpreted in accordance with Ricci-Lucchi $(1969,1975)$ and Mutti \& Ghibaudo (1972) as resulting from progressive channel abandonment, depositing progressively thinner and finer grained beds from smaller and smaller flows in the channels. In this connection it is worth stressing that the thinning/fining upwards cycles of turbidite sequences are fundamentally different from the well-known fining upwards sequences which are inferred to have formed by lateral migration of the channels across alluvial flood plains. Ricci-Lucchi (1975) demonstrated in two turbidite formations of the northern Apennines that channelled cycles are characterized by fining/thinning upwards trends in contrast to non-channelled cycles which are dominated by coarsening/thickening upwards trends. Mutti (1974) places coarse textured sediments displaying fining/thinning upwards cycles in the middle fan region, whereas Walker (1976) records fining upwards cycles from both the channelled portion of suprafan (midfan) lobes and from inner fan channel fills.

\section{d. Inner fan interchannel and midfan association}

\section{Description}

This facies association occurs distal to and envelopes the inner fan channel and lobe association $(b)$. It is volumetrically dominated by graded sandstones deposited in channels (facies 7), interbedded with structureless non-graded sandstones (facies

6 ) and sometimes relatively thin conglomerates (facies 8 ). Dark mudstones (facies 1) and interlaminated mudstone and fine sandstone (facies 4 ) occur scattered as relatively thin units.

The association is characterized by channelling, but the channels are generally shallower and bedding also tends to be thinner than in the former association $(b)$. The association displays well developed fining upwards cycles (fig. 10). The most common sequence is a number of consecutively finer grained graded sandstones overlying each other with or without intervening mudstones. A cycle is normally topped by a mudstone layer (section $33 \mathrm{~A}$, Appendix). In section 34 (Appendix) is shown an example of channels several metres deep filled with mudstone. The wall of one of the mud filled channels shows signs of repeated slumping perpendicular to channel axis along curved slump scars (fig. 40). The floors of other channels in the same section were draped with a thin layer of mud before the channel was filled with a facies 7 sandstone. The channel and its fill was finally draped with another 


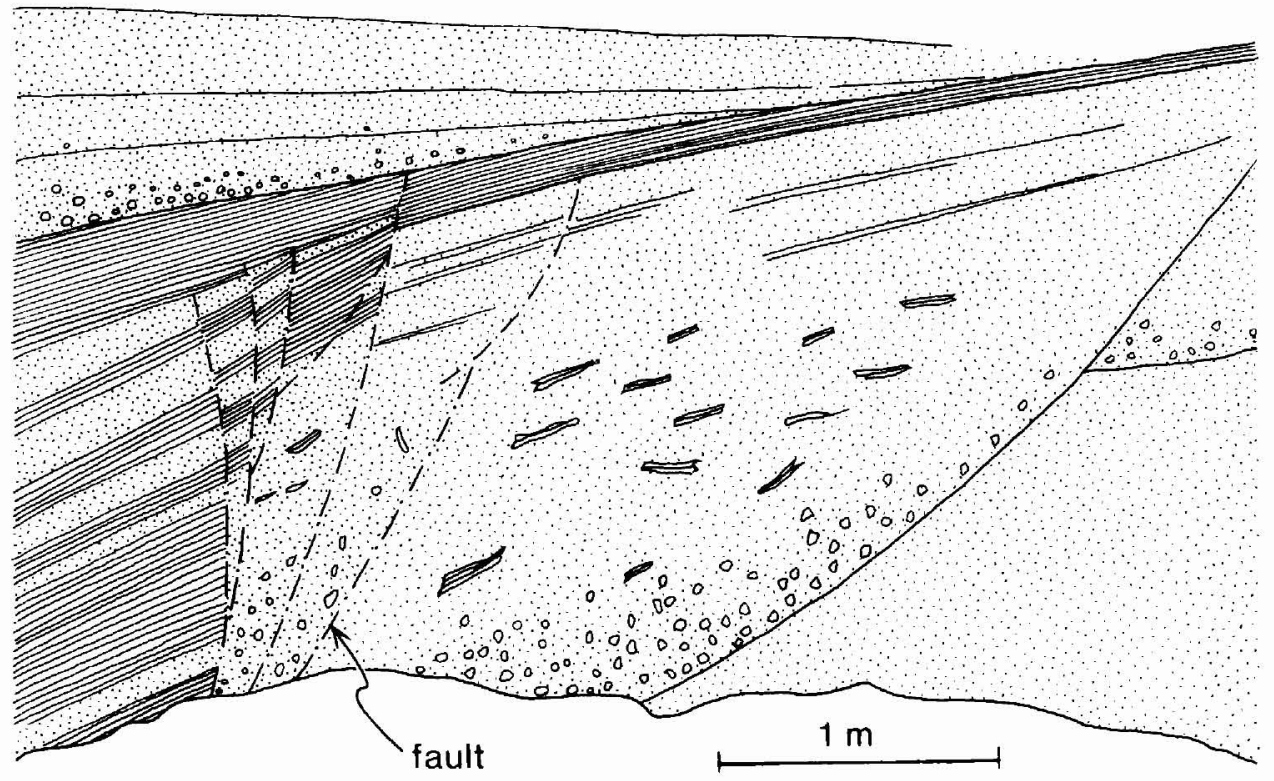

Fig. 40. Synsedimentary slumping along curved scars of channel margin. Deeper part of channel to the left of the figure. Channel mainly filled with mudstone. Section 34 (Appendix) half way up the right section. Rigi Member, south side of Niesen, north Wollaston Forland. Inner fan interchannel association.

mudstone layer. Section 34 is situated at the same stratigraphical level and less than $1 \mathrm{~km}$ along depositional strike from the inner fan channel sediments of section 29-33 (Appendix, fig. 39).

\section{Interpretation}

This facies association is interpreted as having been deposited in an inner fan interchannel or a midfan channel environment. The more precise location of individual sections in either of the two environments is difficult. The sequence in section 34 (Appendix) is, however, referred to an inner fan interchannel position. The section was probably located between two major inner fan channel systems and repeated cutting off, and abandonment, of channels resulted in the abundance of mud filled channels and mud drapes of channel floors. The palaeocurrent data from the section support this interpretation as they deviate significantly from the dominant west to east pattern, probably reflecting a marginal position on the fan.

The more sandy fining-upwards cycles are probably better placed in the channelled area of the midfan. Thus the area between the main inner fan channels, which are deep and filled with conglomerates, is occupied by a dense network of 
shallow channels of the same general appearance as the more distal channels of the midfan.

The two environments can possibly be distinguished by their position in respect to the inner fan channels and in the sequences of the inner fan interchannel area being generally more muddy and containing abundant mud filled channels.

\section{h. Outer fan association \\ Description}

The association is characterized by interlaminated mudstone and fine sandstone (facies 4 ) and dark mudstone (facies 1 ). It dominates volumetrically the most distal portion of the clastic wedge (e.g. section 20, Appendix). The mudstones are interbedded with non-graded structureless sandstones of facies 6 , and, less commonly, by graded channelled sandstone of facies 7 . Conglomerates (facies 8 ) play a very minor role and occur only as scattered thin beds. It is, however, characteristic that all the sandy beds rarely exceed a few tens of centimetres in thickness, and the west to east thinning almost to zero of the midfan sandstones takes place within a few kilometres. It is significant that the only shallow water features, wave ripple cross-lamination, are found in this association (section 20, Appendix; fig. 8).

\section{Interpretation}

The fine grain size, the distal position in respect to the preceding facies, the rarity of coarse-grained facies types, and of channelling suggest deposition of the association on the outer fan. This does, however, not necessarily imply deposition at greater depth than the more proximal facies associations as witnessed by the occurrence of wave ripple cross-lamination. This unexpected feature is explained simply in terms of the downward tilting of a fault-block resulting in the formation of a depositional basin with greatest depth immediately adjacent to the western fault scarp and the shallowest depth on the eastern uplifted crestal part of the block.

\section{Facies associations of the Palnatokes Bjerg Formation}

\section{a. Base of fault scarp slope association}

\section{Description}

The most proximal parts of the Palnatokes Bjerg Formation is only preserved in a few localities due to later erosion. Furthermore, the biostratigraphical control of these very coarse clastic rocks is not always satisfactory and in isolated outcrops they may be difficult to distinguish on lithological grounds from rocks of the same association belonging to the Lindemansbugt Formation. However, in a few locali- 
ties, notably along the faults of the southern part of the Kuppel Block (fig. 3) disorganized relatively matrix rich breccias and especially conglomerates (figs 25 , 31) occur, which are grouped into this association. They have a high content of clasts of reworked Upper Jurassic and penecontemporaneous Valanginian rocks.

\section{Interpretation}

The position of the sediments adjacent to the bordering faults and their completely disorganized and non-channelled nature suggest deposition at the base of fault scarps. The high matrix content and the abundance of reworked clasts of only slightly lithified sediments indicate transport and deposition from debris flows rather than the elastic transport envisaged for the Lindemansbugt part of the association.

\section{b. Inner fan channel and lobe association}

\section{Description}

Conglomerates (facies 8) dominate, and are interbedded with minor amounts of graded channelled sandstone (facies 7) and structureless non-graded sandstone (facies 6). Interlaminated mudstone and fine sandstone (facies 4) occur in small quantities. The conglomerates are generally more matrix-rich and somewhat less channelled than in the same association $(b)$ in the Lindemansbugt Formation, and the association is volumetrically much less important. It occurs, as the $a$ association of the Palnatokes Bjerg Formation mainly in scattered outcrops along the main fault-zones.

\section{Interpretation}

The proximal position of the association and its coarse grain size suggest deposition of the association on the inner fan. The matrix-rich, little or non-channelled conglomerates were probably laid down by non-erosive debris flows on inner fan lobes whereas the more channelled varieties were laid down by sediment flows possessing greater erosive power.

\section{e. Midfan and inner fan interchannel association}

\section{Description}

This association deviates from the corresponding association of the Lindemansbugt Formation $(d)$ in being dominated by graded sandstones with more or less horizontal base and great lateral extent (facies 5). This facies is absent from the Lindemansbugt Formation. It is the only one of the coarser facies that can be 
adequately described by the Bouma model, and the sequence mainly comprises the A-B-E or A-E Bouma Divisions. The sandstones very often form thick units by amalgamation of A, B and A-B Divisions. Light grey mudstones of facies 2 occur interbedded with these proximal non-channelled turbidites. They are, however, less important volumetrically. Dark mudstones (facies 1), interlaminated mudstone and fine sandstone (facies 4), and structureless non-graded sandstone (facies 6) are found in small quantities. Fining-upwards cycles are conspicuous in some of the more sandy sections (e.g. $18^{5}$, Appendix).

The association occupies a central and strike-parallel position in the basin.

\section{Interpretation}

The intermediate position in the basin, distal to the inner fan channel sediments, and the dominance of proximal, amalgamated turbidites suggest deposition on midfan depositional lobes (suprafan). The occurrence of fining-upwards cycles is, however, interpreted as resulting from deposition in wide channels for those parts of the sequence. Sediments deposited in the midfan may, however, be impossible to distinguish from sediments laid down in inner fan interchannel areas, and a more specific placing in one of the two environments must be deduced from position in relation to the other associations.

\section{f. Distal midfan and outer fan association}

\section{Description}

This association contains the same facies as the former association but in different proportion. The dominant facies is now the light grey mudstone of facies 2 , with the proximal turbidites of facies 5 playing a minor role. In a distal direction the proximal turbidites tend to disappear, the thickness of the individual turbidites decreases and the higher Bouma Divisions might be developed (e.g. section 13, Appendix; Surlyk \& Clemmensen, 1975a).

\section{Interpretation}

The position of the association, distal to the midfan (suprafan) association, the dominance of fine-grained sediments and the more 'distal' character of the turbidites suggest deposition on the distal part of the midfan and the outer fan. 


\section{g. Basin and shoals on submerged block crest association}

\section{Description}

The only facies of the association are the light grey mudstones and red mudstones of facies 2 and 3 respectively. The light grey mudstones occur distally to the sediments of the preceding association $(f)$ and are spread as a relatively thin cover all over the area, in many localities with pronounced stratigraphical overstep on older eroded formations. The red mudstones seem to be restricted mainly to positions over uplifted crests. They are either interbedded with, or overlap the light grey mudstones but they never occur below them. In a few localities they are the only facies represented of the two formations treated in the present paper. In these cases (e.g. over a slightly older late Jurassic fault-zone in the inner reaches of Cardiocerasdal (fig. 7)) they only form a thin overstepping veneer a few metres thick.

\section{Interpretation}

This association is not considered to be a part of the submarine fan system. Rather it forms a condensed sequence of hemipelagic or very dilute turbidity current deposits on structural highs such as uplifted margins of tilted blocks or narrow isolated fault blocks (uplifted block in the southern part of the Kuppel Block, figs $3 \& 7$ ).

\section{c. The Clavering $\varnothing$ association}

Only one section (section 44, Appendix) was measured in a coastal profile on Clavering $\varnothing$. The succession is extremely uniform throughout the section and the only facies represented are stratified pebble conglomerates (facies 9) and matrix rich disorganized cobble conglomerates (facies 8 ). Precise age relations and lateral facies changes are unknown. The sequence is therefore difficult or impossible to refer to a specific environment, although closely related facies have been described by Davies \& Walker (1974) as occurring together with conglomerates interpreted as deposited in inner fan channels.

The lack of channelling and of any sequential pattern in the more than $150 \mathrm{~m}$ thick succession precludes a fan channel environment. Since the association with a few insignificant exceptions is restricted to the Clavering Block it is suggested that this block experienced tectonic movements which were different from the continentwards antithetic rotation of the other fault blocks. It is thought that the Clavering Block was tilted away from the mainland instead of against it. In such a case no fault scarp would have formed and the faulting episodes would probably have been of a less catastrophic nature and the mainland would not have been rejuvenated to the same extent as in the Wollaston Forland area. Boulder conglomerates would be 
absent and the transporting mechanisms would be intermediate between turbidity and traction currents. Sedimentation would take place down the gently sloping dip-slope of the fault block. In such a situation submarine fans were less likely to develop.

\section{Vertical sequence of environments}

\section{Description}

On the basis of the lithostratigraphic mapping, good biostratigraphical control, and comparison of many vertical sections it has been possible to deduce the spatial distribution of the different facies associations.

The tilted and eroded Middle and Upper Jurassic rocks of the Vardekløft and Bernbjerg Formations (fig. 4) are overlain unconformably by resedimented breccias, conglomerates, sandstones, and subordinate mudstones of the Lindemans Bugt Formation. This formation is, as already noted by Maync $(1947,1949)$, restricted to the deepest parts of the fault-bounded basins adjacent to the western fault scarps. It wedges out rapidly towards the eastern crestal areas of the blocks, which possibly formed islands, peninsulas, or shoals during deposition. The 1-2 km thick Lindemans Bugt Formation can be divided into three to five megacycles each comprising a mainly coarsely structured unit dominated by the breccias and conglomerates of the base of fault scarp slope and inner fan associations, and a finer grained unit dominated by the midfan association. The megacycles cannot be demonstrated in the measured sections due to the vertical extent of the latter being limited by generally poor exposure. The megacycles are, however, major landscape forming elements, the coarse units forming pronounced terraces. The presence of about three major conglomerate horizons was discovered by Vischer (1943), who attempted to use them as marker beds for mapping purposes.

The dominant vertical trend within both the coarse and the fine units of a megacycle is the ubiquitous occurrence of smaller fining-upwards cycles varying in thickness between 5 and $25 \mathrm{~m}$. Sections which span the boundary between the coarse and the fine megacycle unit (e.g. sections 49-50, Appendix), clearly show that there is a general fining-upwards trend also across the boundary layers. In addition the coarse megacycle unit begins, in its proximal parts, with extremely coarse-grained beds and it forms without doubt the lower part of a generally upwards fining megacycle.

The formation is thus built of at least three to five 2-300 metres thick fining-upwards megacycles composed of (from bottom to top): (1) base of fault scarp slope association, (2) inner fan channel and interchannel associations, (3) midfan association, (4) outer fan association (fig. 41).

The palaeocurrent pattern is extremely regular. In the most proximal facies 


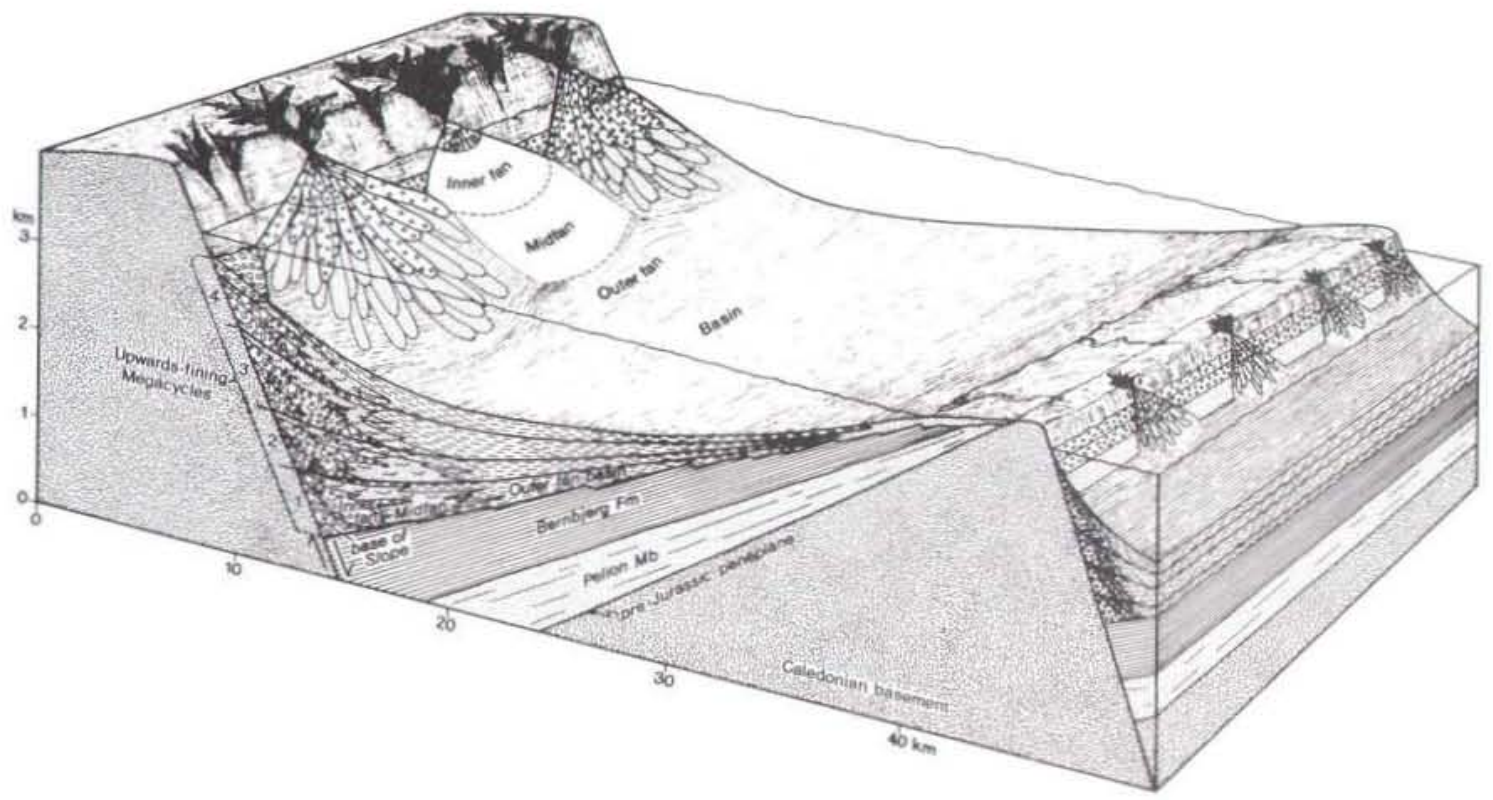

Fig. 41. Block diagram constructed to demonstrate the interpreted palacoenvironments and resulting facies distribution of the Wollaston Forland Group. The clastic wedge is built of four upwards-fining megacycles each of which corresponds to the model shown on fig. 44. The diagram is based on western Wollaston Forland and the fault scarp to the left corresponds to the Dombjerg Fault.

associations of the lower unit transport is west to east at a right angle to the fault scarp. In the upper unit transport directions of mid- and outer fan associations deviate somewhat more with a common mode around west to east, but varying from SW to NE over W to E to NW to SE. Sediments were transported and deposited from elastic rockfalls and sediment gravity flows with matrix strength and clast collision-dispersive pressure being the dominant clast supporting factors in the base of slope and inner fan channel associations. In the inner fan interchannel and midfan associations the transporting mechanisms are transitional between liquefied flows and turbidity currents. The outer fan is dominated by sedimentation of mud interrupted by small turbidity currents.

The depositional slope was very steep immediately east of the slightly seawards inclined fault scarp and the main deposition took place here. The slope faded out rapidly and at some distance from the fault the bottom attained first a horizontal position and then, gradually, the dip changed and the slope became gently dipping towards the continent, corresponding to the dip-slope surface of the fault block (fig. 41). The formation shows extremely rapid west to east wedging out and very rapid decrease in thickness and coarseness of facies resulting in thick conglomerate units sometimes wedging out within some hundred metres at a right angle to 
depositional strike. In contrast, the distribution of facies associations is fairly uniform in a $\mathrm{N}-\mathrm{S}$ strike-parallel direction. Only the inner fan-channel association shows some pinching and swelling, but the whole megacycle can be followed for long distances along strike.

The overlying Palnatokes Bjerg Formation represents a pronounced change in sedimentation although the broad facies associations are the same. The Palnatokes Bjerg sediments are generally finer grained than the sediments of the Lindemans Bugt Formation and the base of slope and inner fan-channel associations are restricted to narrow strips adjacent to the faults. The midfan and outer fan associations have, however, much the same areal distribution as in the Lindemans Bugt Formation. A major difference besides dominance of finer-grained rocks and lack of channelling is found in the much greater areal distribution of the Palnatokes Bjerg Formation. Thus the basin association seems to be absent in the underlying Lindemans Bugt Formation where the crestal areas of the blocks generally seem to have been exposed. On the contrary the Palnatokes Bjerg basin association is strongly onlapping and spreads over the previously emerged high areas. There is thus evidence of a general regional transgression corresponding to the start of the Palnatokes Bjerg Formation. This change from deep narrow landlocked basins to more open marine conditions is also mirrored by the fauna, which not only reaches much higher diversities but also contains an abundance of benthic elements.

In spite of the change in facies types in the Palnatokes Bjerg Formation the same fining-upwards cycles characterize the more sandy parts of the succession. In the higher parts of the formation turbidite sediments finally decrease throughout the basin and give way to light grey and red mudstones.

\section{Interpretation}

After deposition of the mid-late Jurassic generally transgressive sequence of the Vardekløft and Bernbjerg Formations (Surlyk \& Clemmensen, in press) a period with strong tectonic activity started in late Jurassic (mid Volgian) times. The tectonics were extensional and resulted in the formation of narrow fault blocks which were rotated and strongly tilted to the west. This antithetic block rotation (Cloos, 1939; Vischer, 1943) gave rise to the formation of north-south orientated troughs limited to the west by the steep fault scarp of the uplifted part of the neighbouring block. The deepest part of the trough was situated at the scarp and depth decreased eastwards, approaching the uplifted crestal area of the block.

A series of submarine fans developed along the most proximal fault scarp (the Dombjerg Fault zone) which limited the emerged continental landmass to the west from the faulted more or less submerged continental margin. The submarine fans were closely spaced (fig. 41) and probably showed overlapping and interfingering. The first phase of deposition immediately after a series of major fault movements was dominated by rockfall and rockfall avalanches direct from the scarp, resulting 
in filling of the deepest part of the trough (base of fault scarp slope association). The submarine fan rapidly built up and filled the trough mainly with conglomerates of the inner fan channel association. Because of the landward dip direction of the fault block sedimentation did not result in progradation of a fan over the lower part of a slope and out into the basin as is commonly the case in rift fault situations (Steel, 1976). Rather it can be characterized as a dominantly vertical aggradation dominated by channel filling and abandonment accompanied by rapid channel shifting and cutting of new channels.

\section{Palaeogeography and tectonics}

By relating the lateral facies distributions to the fault pattern of each stratigraphic level an attempt will be made to outline the palaeogeographical evolution of the area (figs 42-43). It can only rarely be convincingly demonstrated that a fault was active during a stratigraphic interval. Pronounced lateral facies changes approaching the fault, or unconformable overlap of a faulted sequence by undisturbed layers are reliable evidence for contemporaneous fault activity. Somewhat weaker evidence is provided indirectly by absence of a stratigraphical interval on one fault block and its presence on the neighbouring fault block.

\section{Early Kimmeridgian}

The early Kimmeridgian transgression was the most widespread of the series of transgressions which took place in the Jurassic of East Greenland (Sykes \& Surlyk, 1976; Surlyk \& Clemmensen, in press). Except for the most marginal areas deposition was dominated by the black mudstones of the Bernbjerg Formation (fig. 1). The underlying tectonic structure was wide $\mathrm{N}-\mathrm{S}$ orientated fault blocks, which were slightly tilted to the west.

\section{Middle Volgian}

In mid-Volgian times the Wollaston Forland area was broken up into $10-30 \mathrm{~km}$ wide, mainly $\mathrm{N}-\mathrm{S}$ striking, fault blocks, which were strongly tilted westwards towards the continent. The western, down tilted ends of the blocks were submerged immediately upon faulting, whereas the eastern, uptilted seawards block crests formed islands, peninsulas and shoals. The sea was restricted to narrow N-S running fjords, the most prominent of which was the fjord limited by the Dombjerg-Thomsen Land Fault to the west and the crestal part of the Kuppel-Kuhn Block to the east (fig. 43). This palaeogeographical setting has already been noted by Maync $(1947,1949)$. A fringe of alluvial fans formed along the fault scarp and 

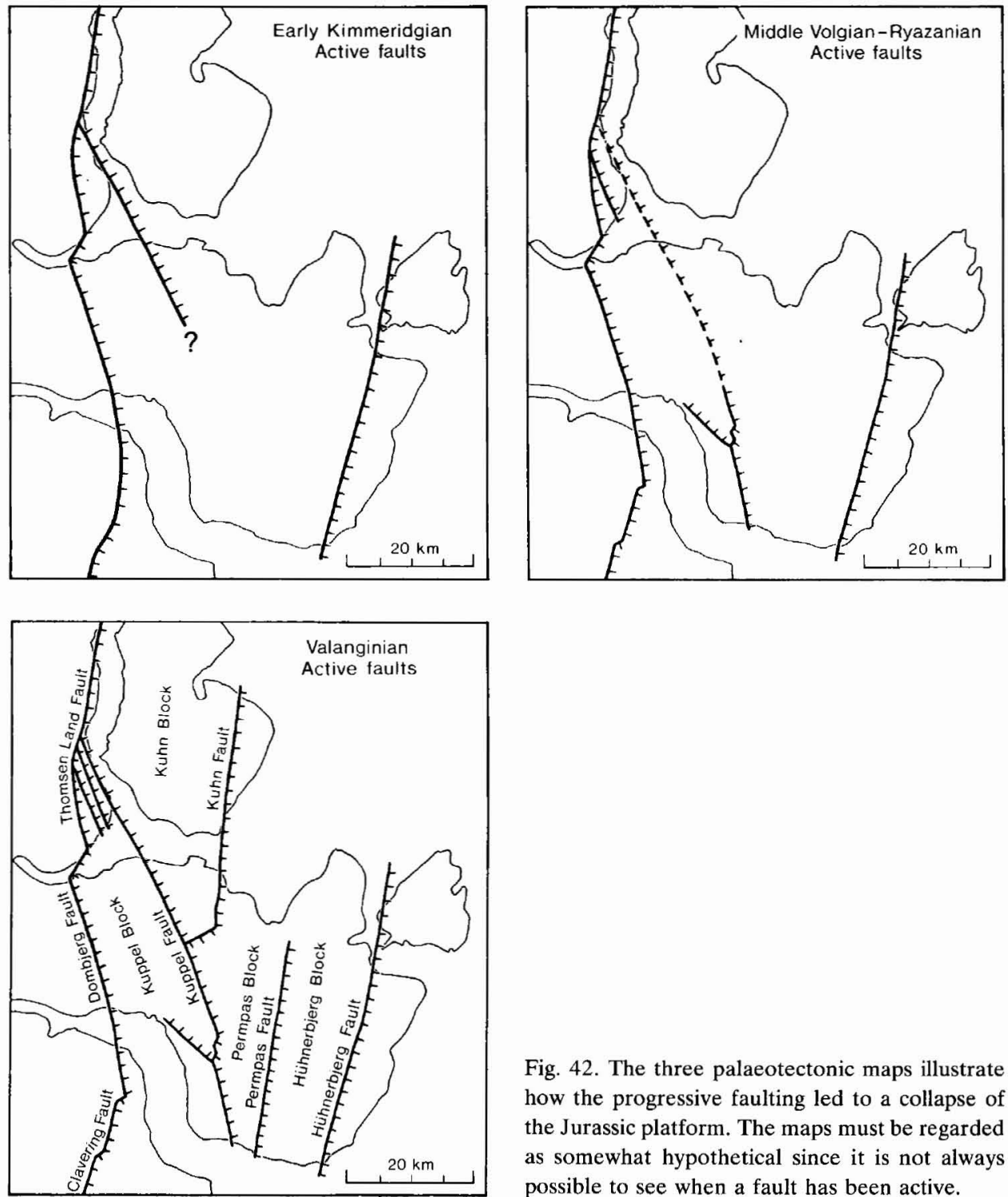

Fig. 42. The three palaeotectonic maps illustrate how the progressive faulting led to a collapse of the Jurassic platform. The maps must be regarded as somewhat hypothetical since it is not always possible to see when a fault has been active.

continued direct down into a system of overlapping submarine fans. The inner and midfan areas had a radius of approximately $10 \mathrm{~km}$, whereas the total fan radius reached $15-20 \mathrm{~km}$. Shallow water regions were reached in the distal parts of the outer fan, approaching the block crest. The palaeogeography of the Permpas and Hühnerbjerg Blocks is unknown because the Volgian rocks here are buried under younger sediments or were never deposited. The emerged landmasses of the Kup- 
pel-Kuhn Blocks were rather narrow and with a subdued topography since the major part corresponded to the gently westwards inclined dip slope of the block. The surfaces of the block crests were in part covered by the mid-late Jurassic Vardekløft and Bernbjerg sediments which formed source areas during the first stages of erosion. It is not known if the southern part of the Permpas Block was submerged since no Volgian sediments have been found east of the Kuppel Fault. If the southern Permpas Block formed a depositional basin the fill probably was fine-grained originating from the eroded mid-late Jurassic sediments and redeposited from turbidity currents and turbid layers. On the submerged parts of the more easterly blocks pelagic sedimentation probably increased in importance and the seaward situated troughs might have been empty or filled only to a minor extent by overflow and ponding during the first tectonic phases.

\section{Ryazanian}

The tectonic activity which started in mid-Volgian times continued unchanged through the late Volgian and Ryazanian. A major phase of block tilting can, thus, be demonstrated to have taken place in latest Volgian times since in section 20 (fig. 5) there is a pronounced angular unconformity between outer fan association mudstones of the Laugeites Ravine Member and the overlying latest Volgian midfan association sandstones and conglomerates of the Rigi Member. Relief in the source areas was repeatedly created during the Ryazanian, and the blocks were progressively tilted toward the continent and hence submarine fan systems continued to develop. The source areas for the clastic sediments were progressively unroofed. In the Permpas Block, which received detritus from the Kuppel-Kuhn Blocks, the early Vardekløft and Bernbjerg sediments gave way later to deeper derived Caledonian basement material.

\section{Valanginian}

During the Ryazanian-Valanginian transition a major regional transgression submerged the relatively low-lying parts of the crests of the blocks. At the same time faulting, partly along new lines, led to uplift and rapid erosion of older sediment covered blocks. Thus the Valanginian rests with marked erosional and angular unconformity on the older rocks at many localities. This is especially characteristic in the Cardiocerasdal area (fig. 7) along the northern margins of the landmass of south-west Wollaston Forland.

The submerged shallow shelf areas that formed during regional transgression affected the nature of the deeper water fan sedimentation. Fan sediments became finer grained, flow was less channelled and fan slope was less steep. Most deposition took place on broad depositional lobes instead of in the complex system of shifting channels characteristic of the Middle Volgian-Ryazanian Lindemans Bugt 


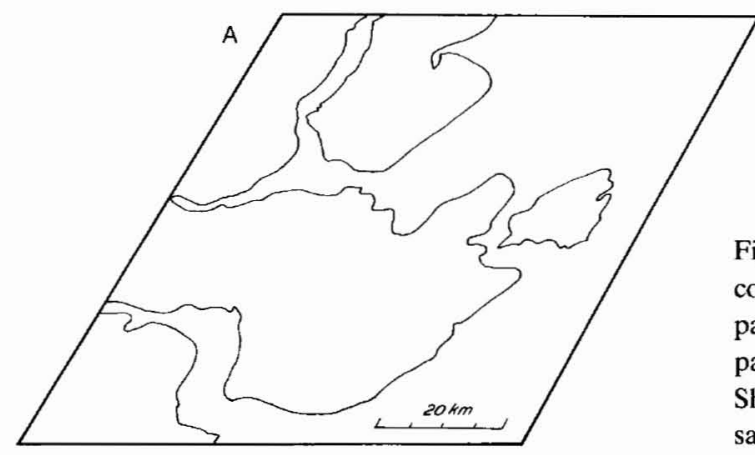

Fig. 43. B-G: A series of maps showing reconstructed late Jurassic-early Cretaceous palaeogeology, palaeogeography and facies patterns for the Wollaston Forland area. A: Shows the present day topography for the same area.
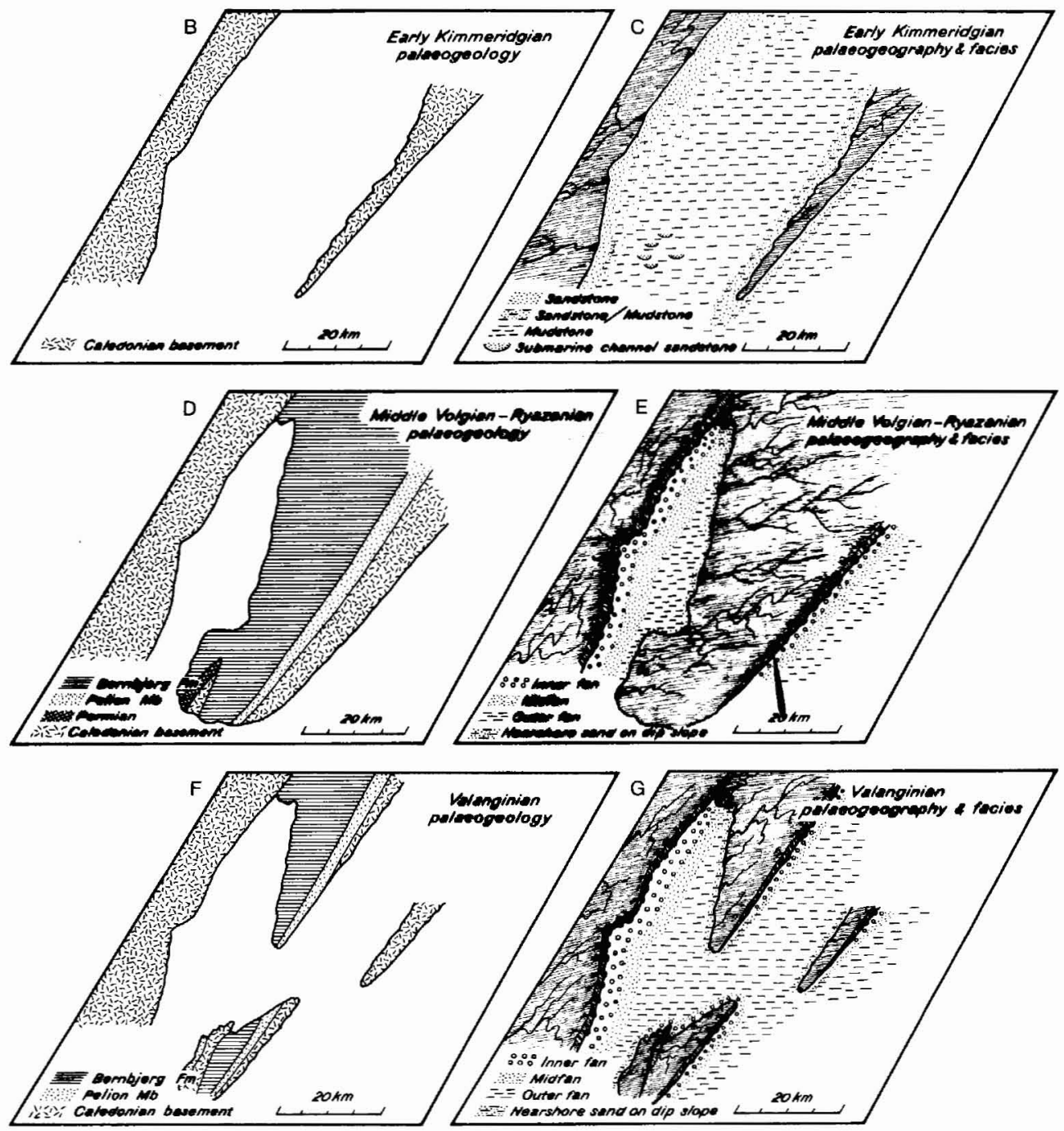
Formation. However, most Valanginian facies show evidence of a large amount of reworking of older uplifted fan material, witnessed by extremely good rounding and iron-staining of quartzite pebbles, and by abundant occurrence of penecontemporaneous clasts of semilithified mudstones (fig. 25).

The eastern seaward troughs were filled with fine-grained sediments probably mainly transported by dilute turbidity currents and in turbid layers. The Hühnerbjerg Fault was active and small fans were constructed along the emerged parts of the Hühnerbjerg Block. The coarse-grained Falskebugt Member sediments which occur along the western side of the block constitute the only positive evidence of deposition of fan type sediments from the crest onto the dip slope of a fault block. In all other cases the sedimentary cover has been removed by later (Pleistocene) erosion. The troughs on the Permpas and Hühnerbjerg Blocks were filled with light grey mudstones whereas thin red mudstones were deposited on top of the grey mudstones and particularly on the submerged parts of the crestal areas of the Kuppel Block.

\section{Hauterivian and Barremian}

Following the Valanginian Stage there seems to have been a period of uplift and emergence, and deposits from the following two stages, the Hauterivian and the Barremian are not known from the area.

\section{Aptian-Albian}

The area was again submerged in the Aptian and Aptian-Albian deposits drape the faulted and eroded Valanginian and older rocks (fig. 7) signifying tectonic activity in the area in the latest Valanginian or in the following period of emergence.

\section{Tectonic-sedimentologic model for submarine fan sedimentation along fault scarps in a tilted fault block situation}

The well established model for submarine fans has mainly been developed on the basis of Recent fans in the southern Californian continental borderland basins, although fans from many other areas have also been studied (see Shepard \& Dill, 1966; Nelson \& Kulm, 1973; and Whitaker, 1974 for reviews of fan sizes and geometry). It is also well known that the fan model developed by Normark (1974) and other workers is generally applicable to almost all types of fan ranging from small fans formed where rivers empty into deep lakes, over small enclosed borderland fans to medium-sized deep-sea fan-abyssal plain situations. The huge fans 
such as the Amazon Cone (Damuth \& Kumar, 1975) or the Bengal fan (Curray \& Moore, 1971) may not be adequately covered by the model. The general concept of a deep-sea fan is, however, a fan or cone shape sediment body deposited on the lower part of the continental slope and in the adjacent parts of the basin outside a deep submarine canyon cut into the continental slope. Sediment from the shelf area is trapped in the canyon head and funnelled downslope through the canyon. The tendency towards radial symmetry is the most fundamental attribute of submarine fans and distinguishes them from elongate bodies of turbidite deposits such as fills of deep-sea channel trenches (Nelson \& Kulm, 1973).

The steady-state model (growth pattern) proposed by Normark $(1970,1974)$ for fan deposition defines the basic morphology, shallow structure, and surface sediment distribution of undisturbed deep-sea fans. This growth pattern reflects the sediment discharge and grain size of sources. The actual shape of the fan depends on tectonic features of the basin margin, the patterns of other depositional systems and channels in the region, and the gradual shift of channel systems to form a radial pattern (Nelson \& Kulm, 1973).

Several authors (e.g. Nelson \& Kulm, 1973; Normark, 1974; Nelson \& Nilsen, 1974) have analysed the effects of changes in the above-mentioned factors on deep-sea fans.

Important differences in growth patterns can result from changes in grain size, composition of sediment available to a fan system, rate of sediment supply, tectonic movements, bottom currents, and sediment slumping. Fans only supplied with fine-grained sediments such as the Bengal fan (Curray \& Moore, 1971) seem never to exhibit the suprafan deposits of Normark (1970). All fans bearing a suprafan deposit have appreciable amounts of coarse sediment (Normark, 1974).

Rapid changes in sea level result in migration of the littoral drift zone relative to the canyon head. This leads to marked changes in the rate of sediment supply. For example the Holocene rise of sea level and entrapment of river and littoral drift sediments in estuaries, shoreline areas, and the inner shelf have prevented deposition of coarse-grained sediments in many fan systems (Nelson \& Kulm, 1973).

Recent continental borderland submarine fans are among the best known and their ancient analogues probably provide better rock records than the fans of open ocean basins because of the typical extensional and uplift tectonics of such areas (Nelson \& Kulm, 1973). The submarine fans described in this paper belong to the category of continental borderland fans, but deviate from most described examples in being deposited along fault scarps on fault blocks tilted towards the continent. The antithetically rotated fault block has been recognized as the main structural unit in many passive margins, and along rift zones interpreted as failed spreading arms. This has been demonstrated particularly well in the exploration work preceding and following the discovery of major oil fields along the northern North Sea grabens (Whiteman et al., 1975; Woodland, 1975).

Submarine fan bodies on tilted fault blocks show a number of characteristic 
features which can be extracted to establish a model for this specific setting. Such a model will hopefully provide a useful framework for work on ancient continental borderland fans. Furthermore, isolated two-dimensional outcrops of submarine fan sediments might be more satisfactorily interpreted. Finally the Wollaston Forland fans and the constructed model possibly constitute the best known analogue to the tectonic-sedimentologic setting of the North Sea grabens. Consequently the model might give a useful insight into the internal and external geometry and nature of these Mesozoic structures and resulting coarse-grained sediment prisms which are otherwise known only from seismic work and drilling.

The characteristic features of the model appear most clearly on the proximal fault blocks to the continent. The more distal fault block basins are situated in progressively deeper water and often show ponding and reduced sedimentation dominated by clay sized material. The model therefore tends to break down in more offshore and deeper water basins.

The model for submarine fans along scarps on tilted or rotated fault blocks displays the following characteristics (fig. 44):

(1) Submarine fans overlap and form a continuous fringe along the fault scarp. The radiating pattern is consequently less clearly developed than in an isolated deep-sea fan.

(2) The fans can be divided into the following facies associations occurring in a proximal-distal succession: (a) Base of fault scarp slope association characterized by chaotic breccias and conglomerates deposited from submarine rockfalls and rockfall avalanches. (b) Inner fan channel and lobe association characterized by conglomerates interbedded with thick graded sandstones deposited in channels or, less commonly, with structureless non-graded sandstones. The association displays ubiquitous channelling and is commonly arranged in fining-upwards cycles. The transport mechanisms consist of various types of sediment gravity flows comprising all types of transitions from debris flows, grain flows and liquefied flows to turbidity currents. (c) Inner fan interchannel association envelopes the former association but is dominated by graded sandstones deposited in channels interbedded with non-graded sandstones and mudstones. The sediments are deposited from turbidity currents or flows transitional between liquefied flows and turbidity currents. (d) Midfan association occurs distally to the three former facies associations, but is otherwise similar to the inner interchannel association. (e) Outer fan association is characterized by mudstone and interlaminated mudstone and fine sandstone. Thin graded or non-graded sandstones occur scattered. All sediments were probably laid down by turbidity currents. (f) Basin association comprises mudstones. It is often strongly reduced in thickness and does not form part of the fan system.

All facies associations contain marine fossils. The three or four proximal associ- 
Continent

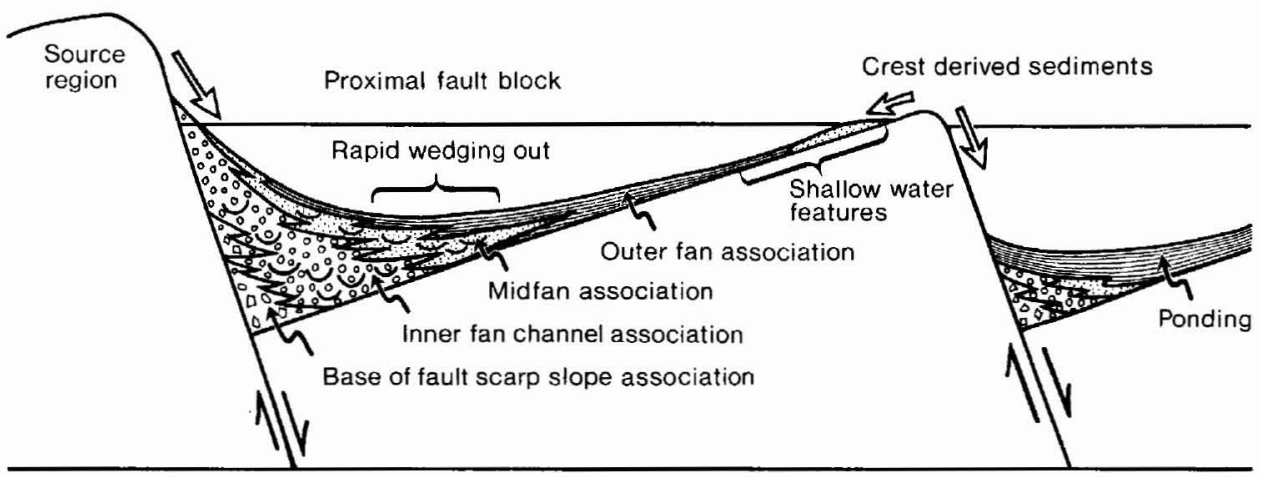

Fig. 44. Model for submarine fan sedimentation along scarps in a tilted fault block situation. The upwards-fining basin fill shown on the figure corresponds to one phase of down-faulting. The block diagram on fig. 41 comprises four such megacycles.

ations contain mainly redeposited fossils whereas the fifth and sixth associations contain an indigenous fauna.

(3) Initiation of the fan sequence is marked by proximal breccias and conglomerates representing base of fault scarp slope association. These rocks often contain clasts of very large size.

(4) Conglomerates are volumetrically important in the basin fill and occur as thick relatively uniform strike-parallel units in contrast to isolated canyon-fan system conglomerates which occur as slope parallel strings of canyon and inner fan channel fills.

(5) The coarsest sediments seem mainly to have been transported by debris flows transitional to grain flows. Matrix content, clast fabric and presence of grading give useful information on which type(s) of clast supporting factors dominates the individual flows. The models for resedimented conglomerates recently proposed by Walker (1975b) do not seem to be applicable in all situations and their supposedly universal nature must be rejected. They are, however, of considerable descriptive value. Sandstones are probably deposited from turbidity currents and flows transitional between grains flows, liquefied flows and turbidity currents. The Bouma model is only rarely applicable, and only $\mathrm{A}-\mathrm{B}-\mathrm{E}$ or $\mathrm{A}-\mathrm{E}$ divisions occur in any abundance. The more fine-grained sediments occurring distal to or interbedded with sandstones and conglomerates are probably laid down by dilute turbidity currents. 
(6) Basin fill is often arranged in several hundred metres thick fining-upwards megacycles corresponding to major phases of faulting and down tilting of the continent side of fault blocks, and representing gradually diminishing supply following rapid erosion and retreat of borderlands.

(7) Megacycles are internally composed of fining-upward cycles a few metres to some tens of metres thick. These cycles reflect progressive filling and abandonment of inner and midfan channels.

(8) Clast composition shows close resemblance to bedrock in immediately adjacent source region (i.e. the neighbouring block in a direction towards the continent). Distal beds may, however, contain crest derived coarse material, which may be petrologically different from proximal sediments, and they may furthermore contain shallow water features such as wave ripple cross-lamination and shallow water faunas.

(9) The coarse-grained units wedge out extremely rapidly in a proximal-distal direction where the seaward dipping fan slope changes to a slope dipping towards the continent (dip slope of the fault block).

(10) Outer fan mudstones are often euxinic owing to shoal or barrier effect of the uptilted block crest.

Fig. 44 shows most features of the model. Only one megacycle is shown. It is interpreted as an aggrading trough-fill following a major phase of faulting and block tilting.

\section{Comparison with the submarine fan-abyssal plain model}

The model outlined here for submarine fans along scarps on tilted fault blocks compares well with the general submarine fan model in most respects. In regionally well-exposed areas the crucial points distinguishing the two models will be the positive correlation between increasing water depth and distal position in the shelf-slope-basin model in contrast to the negative correlation of the two factors in the model presented here. Furthermore, the ubiquitous occurrence of fining-upwards cycles is probably characteristic of the tilted fault block model. Fining-upwards cycles are well-known also from the shelf-slope-basin model, but are here mainly restricted to portions of the channelled midfan, whereas the overall fan growth seems to be characterized by progradational coarsening/thickening-upwards sequences.

Another major difference seems to be the lack in the model proposed here of 
isolated canyons situated proximal to the fan, whilst the shelf-basin model normally has a well-defined canyon cut into fine-grained slope sediments and leading down into a deep-sea fan.

In small, two-dimensional sections the exposed sequences can be very difficult to place in either of the two models, but very coarse grain sizes, dominance of gravity flow transport other than turbidity currents, strong channelling, occasional shallow water features, and the presence of fining-upwards cycles all point towards deposition on a tilted fault block fan.

\section{ECONOMIC GEOLOGY}

The Jurassic-Lower Cretaceous sequence of the Wollaston Forland area has not been the subject of any detailed prospecting activities, but economic minerals do not seem to be present in significant quantities (Nielsen, 1976).

The discovery of the northern North Sea oil fields has, however, resulted in the East Greenland Mesozoic basin being the focus of considerable attention. The basin constitutes the only good onshore analogue to the northern North Sea troughs as it contains almost identical sedimentary sequences in the same general tectonic setting (Surlyk, 1977).

\section{Source rocks}

Source rock analyses have not yet been carried out on Jurassic-Lower Cretaceous samples from the Wollaston Forland area. The Upper Oxfordian-Kimmeridgian Bernbjerg Formation is, however, almost identical to the major source rock for most of the Mesozoic North Sea oil, the Kimmeridge Clay. The Bernbjerg Formation is an up to $600 \mathrm{~m}$ thick, monotonous sequence of black, sandy mudstones which conformably overlies the Bathonian-Oxfordian sandy Vardekløft Formation (Surlyk, 1977). The same formation if present offshore in a more fine-grained facies could have great potential as a source rock.

\section{Reservoir rocks}

The oldest Jurassic sediments of the area belong to the Vardekløft Formation. The bulk of the formation is referred to the Pelion Member which is a sequence of well-sorted, shallow marine sandstones up to $500 \mathrm{~m}$ thick (Surlyk, 1977). It is closely related in age, depositional environment, and tectonic setting to the Middle Jurassic Brent Sand Formation, which is the main reservoir in the Viking Graben (Bowen, 1975; Skipper, 1977).

No detailed work has been carried out on porosity and permeability of the Pelion Member, whereas the facies distribution, transport directions, and depositional 
environments have been studied in some detail (Surlyk, 1977; Surlyk \& Clemmensen, in press).

Smaller sandstone bodies of late Jurassic age occur along the margins of the basin. They are thinner, generally more muddy and their shape less predictable than the sandstones of the Pelion Member, and are consequently less promising as potential reservoir rocks (see Surlyk, 1977 and Surlyk \& Clemmensen, in press). They might be analogous to the shallow water beach/bar sands which constitute the reservoir of the Piper Oil Field (Williams et al., 1975).

The extremely coarse-grained submarine fan bodies up to $4 \mathrm{~km}$ thick described in the present paper have been the subject of considerable attention as potential reservoirs. The lower Lindemans Bugt Formation comprises mainly very coarsegrained and extremely poorly sorted sandstones and conglomerates, which show signs of very early calcite cementation. Porosity and permeability have not been studied in detail but are estimated to be low, and especially inner and middle fan associations probably have poor reservoir characteristics, whereas the sands of the outer fan association are cleaner and better sorted.

The overlying Palnatokes Bjerg Formation was deposited in the same general environment but under transgressive conditions. The main implication of the transgression is that large block crest areas were submerged, and that the clastic material thus underwent abrasion and sorting on these shelf areas. Consequently the Palnatokes Bjerg sandstones and conglomerates are cleaner and much better sorted, and thereby have higher initial porosities than the Lindemans Bugt sediments. Especially the mid and outer fan associations may be rated as good potential reservoirs.

This difference between otherwise comparable associations of the Lindemans Bugt and Palnatokes Bjerg Formations is an important point. It implies that subsurface occurrences of submarine fan deposits along fault scarps may be of very different potential as reservoirs even if the general depositional environment was the same.

The Wollaston Forland submarine fan sequences have possible analogues in the Brae and Thelma discoveries (e.g. Skipper, 1977).

\section{Traps}

The Jurassic sequence was faulted, tilted and eroded in Volgian to Valanginian times (fig. 41) and consecutively draped by impermeable sandy Aptian-Albian mudstones. The Upper Jurassic Bernbjerg mudstones may also form effective seals over the mainly Middle Jurassic Pelion sandstones, where they have not been removed by later erosion.

A final example is provided by the fine-grained outer fan mudstones of the Wollaston Forland Group which are located on the higher parts of the dip slope 
and on the crests of the tilted blocks and accordingly occur in a situation where they could function as effective seals.

The main trap situation is the same as in the Brent province (e.g. Bowen, 1975). The Jurassic sequence, which may be over $4 \mathrm{~km}$ thick is westward dipping and preserved in fault blocks, and is overlain by unconformable Upper Jurassic and in particular, Lower Cretaceous mudstones, which appear to have very low permeabilities (fig. 7).

\section{Overburden}

The faulted and tilted mudstone, sandstone and conglomerate sequence of the Jameson Land and Wollaston Forland Groups is overlain by up to $900 \mathrm{~m}$ of Lower Cretaceous sediments which are now only preserved in scattered outliers. Upper Cretaceous rocks are absent, and the Tertiary is represented by a thin, poorly known sedimentary sequence, and by thick plateau basalts.

\section{Hydrocarbon potential}

Post-Tertiary epeirogenic uplift and erosion has brought the Jurassic sequence close to the surface or partly removed it. Therefore the onshore area has little or no hydrocarbon potential. This is of considerable interest for the questions and problems concerning environmental protection. Onshore drilling will thus be only for exploration and not for production purposes.

Too little is yet known about the geology of the neighbouring shelf areas. The same structural patterns seem, however, to be characteristic (Johnson et al., 1975) and the Mesozoic sequence is by analogy thought to be roughly the same for comparable tectonic settings. The hydrocarbon potential of the shelf thus to a large degree depends on the thickness of the younger sediments.

\section{Model for North Sea oil fields}

As a conclusion on the economic geology it can thus be stated that the prime importance of the Wollaston Forland area is that it serves as a perfect model for almost all types of source rocks, reservoir rocks, seals, and traps occurring in the Viking-Central Graben (see e.g. numerous papers in Woodland, 1975; Skipper, 1977). 


\section{CONCLUSIONS}

1. The Middle Volgian-Ryazanian-Valanginian sediments of the Wollaston Forland area have for the first time been placed in a lithostratigraphic framework.

The new Wollaston Forland Group contains the new Lindemans Bugt Formation which has been divided into the new Laugeites Ravine, Rigi and Niesen Members, and the Palnatokes Bjerg Formation which has been divided into the Young Sund, Albrechts Bugt, Falskebugt and Rødryggen Members.

2. The sequence has been biostratigraphically zoned. It contains a probably unbroken section across the Jurassic-Cretaceous boundary.

The following zones or beds have been recognized (from below): Laugeites groenlandicus Zone, Epilaugeites vogulicus Zone, 'Virgatosphinctes' tenuicostatus beds, Praetollia maynci Zone, Hectoroceras kochi Zone, Surites (Caseyiceras) analogus Zone, Surites tzikwinianus Zone, Bojarkia mesezhnikovi Zone, Tollia tolli Zone, Buchia keyserlingi Zone, Buchia sublaevis Zone and Buchia crassicollis Zone.

3. A facies analysis of the Wollaston Forland Group has been carried out and the depositional mechanism of each facies has been interpreted.

The following ten facies were recognized: (1) Dark mudstones. (2) Light grey mudstones. (3) Red mudstones. (4) Interlaminated mudstone and fine sandstone. (5) Graded sandstone with subhorizontal base. (6) Structureless, non-graded sandstone. (7) Graded sandstone deposited in channels. (8) Conglomerates (with seven subfacies). (9) Stratified pebble conglomerates. (10) Breccias. Facies 1-3 and the fine-grained parts of facies 4 are interpreted as having settled out from suspension in a marine environment. The sandstone of facies 4 is interpreted as deposited from storm generated suspensions or turbidity currents. Facies $\mid 5-8$ are interpreted as deposited from a variety of sediment gravity flows in a marine environment.

4. Walker (1975a) recently presented a model for resedimented conglomerates in which conglomerates were first divided into clast and matrix supported types and the clast supported type then divided into (a) an inverse-to-normally graded model, (b) a graded stratified model, and (c) a disorganized model. The matrix and clast supported conglomerates of the present study possess roughly the same relative proportion of non-graded, and different types of graded beds. Furthermore, the different combinations of grading type and clast fabric occur in more or less the same relative abundances. Consequently there seems to be no strong a priori reasons to exclude matrix supported conglomerates from the model. The strong distinction between organized and disorganized conglomerates in the models seems also to be more of descriptive than conceptual importance as non-graded beds 
without a developed fabric may rapidly develop an imbricated fabric when traced laterally. Walker's three models - except perhaps the graded stratified model, which is uncommon in the present case - occur in exactly the same setting, are complexly interbedded, and pass rapidly into each other both laterally and vertically in one bed. It can therefore be concluded that it is still necessary to operate with a purely descriptive model, as the models of Walker do not seem to be satisfactory for all resedimented conglomerates.

5. All coarse clastic material was transported away from the fault scarps which formed the margins of the basin and the basin was thus filled laterally. The mean palaeocurrent directions are almost precisely at right angles to the faults.

6. The Caledonian bedrock west of the faults probably formed the source area of the conglomerates since there is a pronounced resemblance between the composition of these rocks and of the clasts of the conglomerates.

7. Eight facies associations are recognized on the basis of an analysis of recurrent facies combinations and sequences and interpreted in terms of submarine fan deposition. The associations of the Lindemans Bugt Formation are interpreted as representing: base of fault scarp slope; inner fan channel and lobe; inner fan interchannel and midfan; outer fan. The associations of the Palnatokes Bjerg Formation are interpreted as representing: base of fault scarp slope; inner fan channel and lobe; midfan and inner fan interchannel; distal midfan and outer fan; basin and shoals on submerged block crest. Finally, an association occurs on Clavering $\emptyset$ in an isolated fault block out of contact with other associations.

8. The vertical sequence of environments is interpreted as coalescent submarine fan bodies along fault scarps filling N-S orientated troughs formed by antithetic block rotation. Because of the landward dip directions of the fault blocks, sedimentation did not result in progradation of a fan over the lower part of a slope and out into the basin as is commonly the case in rift fault situations. Rather it can be characterized as a vertical aggradation dominated by channel shifting and cutting of new channels.

9. The palaeogeographical - palaeogeological evolution of the area is interpreted in terms of a fault-controlled collapse of the wide late Jurassic shelf. Faulting was antithetic and during the first, Middle Volgian phases, only the deepest parts of the troughs were submerged resulting in the formation of $\mathrm{N}-\mathrm{S}$ orientated narrow fjords with stagnant water at the bottom and absence of normal benthic fauna. Continued faulting accompanied by subsidence of the whole region resulted in the Valanginian transgression during which previously exposed block crests were submerged. 
Water circulation was improved and a relatively diverse fauna inhabited the bottom.

10. On the basis of the submarine fan model proposed for the Wollaston Forland Group a general tectonic sedimentological model is presented for submarine fan sedimentation along fault scarps in a tilted fault block situation. This model in plan displays the same facies associations as the well-known model for deep-sea fans. Distinguishing characters are seen in the internal distribution of facies. The sediment prism is arranged in several hundred metres thick fining-upwards megacycles corresponding to major phases of faulting and down-tilting of fault blocks, and representing gradually diminishing supply following rapid erosion and retreat of borderlands. Megacycles are internally composed of fining-upwards cycles a few metres to some tens of metres thick. These cycles reflect progressive filling and abandonment of inner and midfan channels. Furthermore, the very coarse-grained proximal units wedge out extremely rapidly in a distal direction where the seaward dipping slope of the fan changes to the dip slope of the fault blocks which is tilted towards the continent.

11. The Wollaston Forland area has little or no direct hydrocarbon potential. It serves, however, as a perfect model for almost all types of source rocks, reservoir rocks, seals, and traps occurring in the giant oil fields of the Viking-Central Graben of the northern North Sea.

\section{Acknowledgements}

Field work in the Wollaston Forland area in 1974 was supported by the Geological Survey of Greenland. L. B. Clemmensen (Copenhagen, Denmark) is thanked for good company in the field, for numerous discussions and for reading the manuscript. Aspects of the biostratigraphy were discussed with R. Casey (London, U. K.), D. Jones (Menlo Park, California), J. A. Jeletzky (Ottawa, Canada), E. Kemper (Hannover, Germany), and P. F. Rawson (London, U. K.). O. Bjørslev Nielsen (Århus, Denmark) made some clay mineralogical analyses. The stratigraphic part of the manuscript was discussed with R. M. Sykes (Assen, Holland), and the whole paper was read critically by T. Elliott (Swansea, U. K.), B. W. Sellwood (Reading, U. K.) and R. J. Steel (Bergen, Norway) who all offered many helpful and appreciated comments. Drafting of the numerous figures was done by $\mathrm{C}$. Rasmussen, and the photographic work by J. Aagaard, P. Nielsen, J. Lautrup and S. Jakobsen. Typing of several draft versions was undertaken by Annemarie Brantsen. A Russian paper was translated by A. Demina (GGU).

I direct my best thanks to the above-mentioned persons. 


\section{REFERENCES}

Bagnold, R. A. 1954: Experiments on a gravity-free dispersion of large solid spheres in a Newtonian fluid under shear. Proc. R. Soc. (Lond.) A, 225, 49-63.

Bluck, B. J. 1967: Sedimentation of beach gravels: examples from South Wales. J. sedim. Petrol. 37, 128-156.

Bouma, A. H. 1962: Sedimentology of some flysch deposits. A graphic approach to facies interpretation. 168 pp. Amsterdam: Elsevier.

Bowen, J. M. 1975: The Brent oil-field. In Woodland, A. W. (edit.) Petroleum and the continental shelf of North-West Europe. Applied Science Publishers Ltd., 353-361.

Bull, W. B. 1972: Recognition of alluvial-fan deposits in the stratigraphic record. In Rigby, J. K. \& Hamblin, W. K. (edit.) Recognition of Ancient Sedimentary Environments. Spec. Publs Soc. econ. Paleont. Miner. 16, 63-83.

Bütler, H. 1957: Beobachtungen an der Hauptbruchzone der Küste von Zentral-Ostgrönland. Meddr Grønland 160, (1) 79 pp.

Cant, D. J. \& Walker, R. G. 1976: Development of a braided-fluvial facies model for the Devonian Battery Point Sandstone, Québec. Can. J. Earth Sci. 13, 102-119.

Carter, R. M. 1975: Mass-emplaced sand-fingers at Mararoa construction site, southern New Zealand. Sedimentology 22, 275-288.

Casey, R. 1973: The ammonite succession at the Jurassic-Cretaceous boundary in eastern England. In Casey, R. \& Rawson, P. F. (edit.) The Boreal Lower Cretaceous. Geol. J. Spec. Iss. 5, 193-266.

Casey, R., Mesezhnikov, M. S. \& Shulgina, N. I. 1977: Correlation of the boundary deposits of the Jurassic and Cretaceous of England, Russian Platform, the pre-Polar Urals and Siberia. Akademia Nauk SSSR, Ser. Geol. 1977, 7, 14-33. (In Russian).

Casey, R. \& Rawson, P. F. 1973: A review of the boreal Lower Cretaceous. In Casey, R. \& Rawson, P. F. (edit.) The Boreal Lower Cretaceous. Geol. J. Spec. Iss. 5, 415-430.

Clemmensen, L. B. \& Surlyk, F. 1976: Upper Jurassic coal-bearing shoreline deposits, Hochstetter Forland, East Greenland. Sediment. Geol. 15, 193-211.

Clifton, H. E. 1973: Pebble segregation and bed lenticularity in wave-worked versus alluvial gravel. Sedimentology 20, 173-188.

Cloos, H. 1939: Hebung - Spaltung - Vulkanismus. Geol. Rdsch. 30, 4A, 405-525.

Collinson, J. D. 1969: The sedimentology of the Grinslow Shales and the Kinderscout Grit: a deltaic complex in the Namurian of northern England. J. sedim. Petrol. 39, 194-221.

Curray, J. R. \& Moore, D. G. 1971: Growth of the Bengal deep-sea fan and denudation in the Himalayas. Bull. geol. Soc. Am. 82, 563-572.

Dalland, A. 1975: The Mesozoic Rocks of. Andøy, Northern Norway. Norg. geol. Unders. 316, 271-287.

Damuth, J. E. \& Kumar, N. 1975: Amazon Cone: morphology, sediments, age, and growth pattern. Bull. geol. Soc. Am. 86, 863-878.

Davies, J. C. \& Walker, R. G. 1974: Transport and deposition of resedimented conglomerates: the Cap Enrage Formation, Cambro-Ordovician, Gaspé, Quebec. J. sedim. Petrol. 44, 1200-1216.

Donovan, D. T. 1953: The Jurassic and Cretaceous stratigraphy and palaeontology of Traill Ø, East Greenland. Meddr Grønland 111 (4), 150 pp.

Donovan, D. T. 1957: The Jurassic and Cretaceous Systems in East Greenland. Meddr Grønland 155 (4), 214 pp.

Donovan, D. T. 1964: Stratigraphy and ammonite fauna of the Volgian and Berriasian rocks of East Greenland. Meddr Grønland 154 (4), 34 pp.

Dott, R. H., Jr. 1963: Dynamics of subaqueous gravity depositional processes. Bull. Am. Ass. Petrol. Geol. 47, 104-128. 
Faupl, P. 1976: Vorkommen und Bedeutung roter Pelite in den Kaumberger Schichten (Oberkreide) des Wienerwald-Flysches, Niederösterreich. Neues Jb. Geol. Paläont. Mh. 1976, 449-470.

Folk, R. L. 1968: Petrology of Sedimentary rocks, 170 pp. Austin, Texas: Hemphill's.

Frebold, H. 1932a: Grundzüge der tektonischen Entwicklung Ostgrönlands in Postdevonischer Zeit. Meddr Grønland 94 (2), 112 pp.

Frebold, H. 1932b: Geologie der Jurakohlen des nördlichen Ostgrönland. Meddr Grønland 84 (5), 65 pp.

Frebold, H. 1933: Untersuchungen über die Verbreitung, Lagerungsverhältnisse und Fauna des oberen Jura von Ostgrönland. Meddr Grønland 94 (1), 81 pp.

Gressly, A. 1838: Observations géologiques sur le Jura Soleurois. Neue Denkschr. allg. schweiz. Ges. ges. Naturw. 2, 112 pp.

Hallam, A. 1971: Mesozoic geology and the opening of the North Atlantic. J. Geol. 79, 129-157.

Hallam, A. 1975: Jurassic Environments. 269 pp. London: Cambridge University Press.

Hallam, A. \& Sellwood, B. W. 1976: Middle Mesozoic sedimentation in relation to tectonics in the British area. J. Geol. 84, 301-321.

Haller, J. 1970: Tectonic Map of East Greenland (1:500,000). An account of tectonisms, plutonism, and volcanism in East Greenland. Meddr Grønland 171 (5), $286 \mathrm{pp}$.

Haller, J. 1971: Geology of the East Greenland Caledonides. 375 pp. Interscience Publishers.

Hampton, M. A. 1975: Competence of fine-grained debris flows. J. sedim. Petrol. 45, 834-844.

Harms, J. C. \& Fahnestock, R. K. 1965: Stratification, bed forms and flow phenomena (with an example from the Rio Grande). In Middleton, G. V. (edit.) Primary Sedimentary Structures and their Hydrodynamic Interpretation. Spec. Publs Soc. econ. Paleont. Miner. 12, 84-115.

Heinberg, C. 1974: A dynamic model for a meniscus filled tunnel (Ancorichnus n. ichnogen.) from the Jurassic Pecten Sandstone of Milne Land, East Greenland.'Rapp. Grønlands geol. Unders. 62, 20 pp.

Hendry, H. E. 1973: Sedimentation of deep water conglomerates in Lower Ordovician rocks of Quebec - composite bedding produced by progressive liquefaction of sediment? J. sedim. Petrol. 43, 125-136.

Henriksen, N. \& Higgins, A. K. 1976: East Greenland Caledonian fold belt. In Escher, A. \& Watt, W. S. (edit.) Geology of Greenland. 183-246. København. Grønlands geologiske Undersøgelse.

Hsü, K. J. 1974: Melanges and their distinction from olistostromes. In Dott, R. H. Jr. \& Shaver, R. H. (edit.) Modern and ancient geosynclinal sedimentation. Spec. Publs Soc. econ. Paleont. Miner. 19, 321-333.

Jeletzky, J. A. 1965: Late Upper Jurassic and Early Lower Cretaceous fossil zones of the Canadian Western Cordillera, British Columbia. Bull. geol. Surv. Can. 103, 70 pp.

Jeletzky, J. A. 1973: Biochronology of the marine boreal latest Jurassic, Berriasian and Valanginian in Canada. In Casey, R. \& Rawson, P. F. (edit.) The Boreal Lower Cretaceous. Geol. J. Spec. Iss. 5, 41-80.

Johnson, A. M. 1970: Physical processes in geology, 571 pp. San Francisco: Freeman.

Johnson, G. L., McMillan, N. J. \& Egloff, J. 1975: East Greenland continental margin. In Yorath, C. J., Parker, E. R. \& Glass, D. J. (edit.) Canada's continental margins and offshore petroleum exploration. Mem. Can. Soc. Petrol. Geol. 4, 205-224.

Kelling, G. 1976: Significance of clast size, and composition in ancient and modern submarine canyon-fan systems. Bull. Am. Ass. Petrol. Geol. 60, 686.

Kemper, E. 1975: Upper Deer Bay Formation (Berriasian - Valanginian) of Sverdrup Basin and biostratigraphy of the Arctic Valanginian, Geol. Surv. Pap. Can. 75-1, B, 245-254.

Kemper, E. 1977: Biostratigraphy of the Valanginian in Sverdrup Basin, District of Franklin. Geol. Surv. Pap. Can. 76-32, 6 pp.

Koch, L. 1929: The geology of East Greenland. Meddr Grønland 73 (2), 1, 204 pp.

Koch, L. 1939: Zur geologischen Erforschungsgeschichte Ostgrönlands. Mitt. Naturf. Ges. Schaffhausen 16, 70-81. 
Koch, L. \& Haller, J. 1971: Geological map of East Greenland $72^{\circ}-76^{\circ}$ N. Lat. (1:250,000). Meddr Grønland 183, 26 pp.

Leedal, G. P. 1952: The crystalline rocks of East Greenland between latitudes $74^{\circ} 30^{\prime}$ and $75^{\circ} \mathrm{N} . \mathrm{Meddr}$ Grønland 142 (6), 80 pp.

Lowe, D. R. 1976a: Grain flow and grain flow deposits. J. sedim. Petrol. 46, 188-199.

Lowe, D. R. 1976b: Subaqueous liquefied and fluidized sediment flows and their deposits. Sedimentology 23, 285-308.

Maync, W. 1940: Stratigraphie des Küstengebietes von Ostgrönland zwischen $73-75^{\circ}$ N. Lat. Meddr Grønland 114 (5), 5-34.

Maync, W. 1947: Stratigraphie der Jurabildungen Ostgrönlands zwischen Hochstetterbugten $\left(75^{\circ} \mathrm{N}\right.$.) und dem Kejser Franz Joseph Fjord ( $73^{\circ}$ N.). Meddr Grønland 132 (2), 223 pp.

Maync, W. 1949: The Cretaceous beds between Kuhn Island and Cape Franklin (Gauss Peninsula), northern East Greenland. Meddr Grønland 133 (3), $291 \mathrm{pp}$.

Mesezhnikov, M. S., Zakharov, V. A., Shulgina, N. I. \& Aleksev, S. N. 1977: Evidence for the Ryazanian horizon on the Oka River obtained in 1976. International colloquium of the Upper Jurassic and Jurassic-Cretaceous boundary. Novosibirsk - 1977, 103-104.

Middleton, G. V. 1967: Experiments on density and turbidity currents. III. Deposition of sediment. Can. J. Earth Sci. 4, 475-505.

Middleton, G. V. 1970: Experimental studies related to problems of flysch sedimentation. In Lajoie, J. (edit.) Flysch Sedimentology in North America. Spec. Pap. geol. Ass. Can. 7, 253-272.

Middleton, G. V. \& Hampton, M. A. 1973: Sediment gravity flows: mechanics of flow and deposition. Turbidites and deep water sedimentation. Soc. econ. Paleont. Miner. Pacific Section. Short Course Anaheim, 1973, 1-38.

Middleton, G. V. \& Hampton, M. A. 1976: Subaqueous sediment transport and deposition by sediment gravity flows. In Stanley, D. J. \& Swift, D. J. P. (edit.) Marine sediment transport and environmental management, 197-218. John Wiley \& Sons.

Mudge, M. R. 1965: Rockfall-avalanche and rockslide-avalanche deposits at Sawtooth Ridge, Montana. Bull. geol. Soc. Am. 76, 1003-1014.

Mutti, E. 1974: Examples of ancient deep-sea fan deposits from circum-Mediterranean geosynclines. In Dott, R. H., Jr. \& Shaver, R. H. (edit.) Modern and ancient geosynclinal sedimentation. Spec. Publs Soc. econ. Paleont. Miner. 19, 92-105.

Mutti, E. \& Ghibaudo, G. 1972: Un esempio di torbiditi di conoide sotto-marina esterina: le Arenarie di S. Salvatore (Formazione di Bobbio, Miocene) nell'Apennino di Piacenza. Mem. Accad. Sci. Torino, Cl. Sci. Fis. Mat. Nat. (4), 16, 40 pp.

Neale, J. W. 1962: Ammonoidea from the Lower D Beds (Berriasian) of the Speeton Clay. Palaeonto$\operatorname{logy}$ 5, 272-296.

Nelson, C. H. \& Kulm, L. D. 1973: Submarine fans and deep-sea channels. Turbidites and deep water sedimentation. Soc. econ. Paleont. Miner. Pacific Section. Short Course Anaheim, 1973, 39-78.

Nelson, C. H. \& Nilsen, T. H. 1974: Depositional trends of modern and ancient deep-sea fans. In Dott, R. H. Jr. \& Shaver, R. H. (edit.) Modern and ancient geosynclinal sedimentation. Spec. Publs Soc. econ. Paleont. Miner. 19, 69-91.

Nielsen, B. L. 1976: Economic minerals. In Escher, A. \& Watt, W. S. (edit.) Geology of Greenland, 461-486. København: Grønlands geologiske Undersøgelse.

Normark, W. R. 1970: Growth patterns of deep sea fans. Bull. Am. Ass. Petrol. Geol. 54, 2170-2195.

Normark, W. R. 1974: Submarine canyons and fan valleys: Factors affecting growth patterns of deep-sea fans. In Dott, R. H., Jr., \& Shaver, R. H. (edit.) Modern and ancient geosynclinal sedimentation. Spec. Publs Soc. econ. Paleont. Miner. 19, 56-68.

Pettijohn, F. J. 1957: Sedimentary rocks. 718 pp. New York: Harper \& Row.

Ravn, J. P. J. 1911: On Jurassic and Cretaceous fossils from North-East Greenland. Meddr Grønland $45(10), 437-500$. 
Rees, A. I. 1968: The production of preferred orientation in a concentrated dispersion of elongated and flattened grains. J. Geol. 76, 457-465.

Reineck, H.-E. \& Singh, I. B. 1972: Genesis of laminated sand and graded rhythmites in storm-sand layers of shelf mud. Sedimentology 18, 123-128.

Reineck, H.-E. \& Singh, I. B. 1973: Depositional sedimentary environments with references to terrigenous clastics. 439 pp. Berlin, Heidelberg, New York: Springer-Verlag.

Ricci-Lucchi, F. 1969: Composizione e morfometria di un conglomerato risedimentato nel flysch Miocenico romagnolo (Fontanelice, Bologna). G. Geol. 36, 1-47.

Ricci-Lucchi, F. 1975: Depositional cycles in two turbidite formations of northern Apennines (Italy). J. sedim. Petrol. 45, 3-43.

Rodine, J. D. \& Johnson, A. M. 1976: The ability of debris, heavily freighted with coarse clastic materials, to flow, on gentle slopes. Sedimentology 23, 213-234.

Rosenkrantz, A. 1932: Oversigt over Kridtformationen i Østgrønland. Meddr dansk geol. Foren. 8, 196-197.

Saks, V. N. \& Shulgina, N. I. 1974: Basic problems of the Upper Volgian, Berriasian and Valanginian stratigraphy of the Boreal zone. Acta geologica Polonica 24, 543-560.

Seilacher, A. 1973: Biostratinomy: the sedimentology of biologically standardized particles. In Ginsburg, R. N. (edit.) Evolving concepts in sedimentology, 159-177. Baltimore \& London: Johns Hopkins University Press.

Selley, R. C. 1970: Ancient sedimentary environments. A brief survey. 237 pp. London.

Shepard, F. P. \& Dill, R. F. 1966: Submarine canyons and other sea valleys. 381 pp. Chicago: Rand McNally \& Company.

Shulgina, N. I. 1967: Tithonian ammonites of Northern Siberia. In: Problems of paleontological substantiation of detailed Mesozoic stratigraphy of Siberia and the Far East of USSR. Leningrad: 'Nauka', 131-177. (In Russian).

Shulgina, N. I. 1972: Ammonites of the north of middle Siberia. In Saks, V. N. (edit.) The Jurassic-Cretaceous boundary and the Berriasian Stage in the Boreal Realm. Novosibirsk: 'Nauka', 145-186 (In Russian).Translated from Russian. Israel Program for Scientific Translations Jerusalem 1975. Keter Publishing House Jerusalem Ltd.

Skipper, K. 1977: Offshore petroleum developments in Northwest Europe - an update. Geosci. Can. 4, $31-40$.

Spath, L. F. 1936: The Upper Jurassic invertebrate faunas of Cap Leslie, Milne Land. II. Upper Kimmeridgian and Portlandian. Meddr Grønland 99 (3), 180 pp.

Spath, L. F. 1946: Preliminary notes on the Cretaceous ammonite faunas of East Greenland. Meddr Grønland 132 (4), 12 pp.

Spath, L. F. 1947: Additional observations on the invertebrates (chiefly ammonites) of the Jurassic and Cretaceous of East Greenland. I. The Hectoroceras fauna of S. W. Jameson Land. Meddr Grønland 132 (3), $70 \mathrm{pp}$.

Spath, L. F. 1952: Additional observations on the invertebrates (chiefly ammonites) of the Jurassic and Cretaceous of East Greenland. II. Some Infra-Valanginian ammonites from Lindemans Fjord, Wollaston Forland; with a note on the base of the Cretaceous. Meddr Grønland 133 (4), 40 pp.

Stauffer, P. H. 1967: Grain-flow deposits and their implications, Santa Ynez Mountains, California. J. sedim. Petrol. 37, 487-508.

Steel, R. J. 1974: New red sandstone floodplain and Piedmont sedimentation in the Hebridean province, Scotland. J. sedim. Petrol. 44, 336-357.

Steel, R. J. 1976: Devonian basins of western Norway - sedimentary response to tectonism and to varying tectonic context. In Bott, M. H. P. (edit.) Sedimentary basins of continental margins and cratons. Tectonophysics 36, 207-224.

Surlyk, F. 1973: The Jurassic-Cretaceous boundary in Jameson Land, East Greenland. In Casey, R. \& Rawson, P. F. (edit.) The Boreal Lower Cretaceous. Geol. J. Spec. Iss. 5, 81-100. 
Surlyk, F. 1975a: Fault controlled marine fan-delta sedimentation at the Jurassic-Cretaceous boundary, East Greenland. IXth Int. Congr, Sedimentology 4 (2), 305-312.

Surlyk, F. 1975b: Block faulting and associated marine sedimentation at the Jurassic-Cretaceous boundary, East Greenland. NPF - Jurassic Northern North Sea Symposium 7, 1-31.

Surlyk, F. 1977: Stratigraphy, tectonics and palaeogeography of the Jurassic sediments of the areas north of Kong Oscars Fjord, East Greenland. Bull. Grønlands geol. Unders. 123, 56 pp.

Surlyk, F., Callomon, J. H., Bromley, R. G. \& Birkelund, T. 1973: The stratigraphy of the Jurassic-Lower Cretaceous sediments of Jameson Land and Scoresby Land, East Greenland. Bull. Grønlands geol. Unders. 105 (also Meddr Grønland 193, 5), 76 pp.

Surlyk, F. \& Clemmensen, L. B. 1975a: A Valanginian turbidite sequence and its palaeogeographical setting (Kuhn $\varnothing$, East Greenland). Bull. geol. Soc. Denmark 24, 61-73.

Surlyk, F. \& Clemmensen, L. B. 1975b: Sedimentology and stratigraphy of the Middle Jurassic - Lower Cretaceous rocks of the Wollaston Forland - Kuhn $\varnothing$ area, central East Greenland. Rapp. Grønlands geol. Unders. 75, 110-115.

Surlyk, F. \& Clemmensen, L. B. (in press): Jurassic depositional environments in the Wollaston Forland area, East Greenland. Submitted to Sedimentology.

Sykes, R. M. \& Surlyk, F. 1976: A revised ammonite zonation of the Boreal Oxfordian and its application in northeast Greenland. Lethaia 9, 421-436.

Teichert, C. 1958: Concepts of facies. Bull. Am. Ass. Petrol. Geol. 42, 2718-2744.

Toula, F. 1874: Beschreibung mesozoischer Versteinerungen von der Kuhn-Insel. In: Koldewey, K. Die Zweite deutsche Nordpolarfahrt, 2, 497-507. Leipzig: Brockhaus.

Vischer, A. 1943: Die postdevonische Tektonik von Ostgrönland zwischen $74^{\circ}$ und $75^{\circ}$ N. Br., Kuhn $\varnothing$, Wollaston Forland, Clavering Ø und angrenzende Gebiete. Meddr Grønland 133 (1), 195 pp.

Walker, R. G. 1965: The origin and significance of the internal sedimentary structures of turbidites. Proc. Yorks, geol. Soc. 35, 1-32.

Walker, R. G. 1967: Turbidite sedimentary structures and their relationship to proximal and distal depositional environments. J. sedim. Petrol. 37, 25-43.

Walker, R. G. 1973: Mopping up the turbidite mess. In Ginsburg, R. N. (edit.) Evolving concepts in sedimentology, 1-37. Baltimore \& London: Johns Hopkins University Press.

Walker, R. G. 1975a: Conglomerate: Sedimentary structures and facies models. Soc. econ. Paleont. Miner. Short Course 2, Dallas, 1975, 133-161.

Walker, R. G. 1975b: Generalized facies models for resedimented conglomerates of turbidite association. Bull. geol. Soc. Am. 86, 737-748.

Walker, R. G. 1976: Facies models. 2. Turbidites and associated coarse clastic deposits. Geosci. Can. 3, 25-36.

Walker, R. G. \& Mutti, E. 1973: Turbidite facies and facies associations. Turbidites and deep water sedimentation. Soc. econ. Paleont. Miner. Pacific Section. Short Course Anaheim 1973, 119-157.

Whitaker, J. H. McD. 1974: Ancient submarine canyons and fan valleys. In Dott, R. H. Jr. \& Shaver, R. H. (edit.) Modern and ancient geosynclinal sedimentation. Spec. Publs Soc. econ. Paleont. Miner. 19, $106-125$.

Whiteman, A. J., Rees, G., Naylor, D. \& Pegrum, R. M. 1975: North Sea troughs and Plate Tectonics. Norg. geol. Unders. 316, 137-161.

Williams, J. J., Conner, D. C. \& Peterson, K. E. 1975: The Piper oil-field, U. K. North-Sea: a fault-block structure with Upper Jurassic beach-bar reservoir sands. In Woodland, A. W. (edit.) Petroleum and the continental shelf of North-West Europe. 363-377. Applied Science Publishers. 'Nauka', 216 pp. (In Russian).

Woodland, A. W. (edit.) 1975: Petroleum and the continental shelf of North-West Europe. 1. Geology, 501 pp. Applied Science Publishers.

Zakharov, V. A. \& Mesezhnikov, M. S. 1974: The Volgian Stage of the Subarctic Ural. Novosibirsk: 'Nauka', 216 pp. (In Russian).

Ziegler, A. M. \& McKerrow, W. S. 1975: Silurian marine Red Beds. Am. J. Sci. 275, 31-56. 


\section{APPENDIX}

Explanation for symbols used in the measured sections.

Lithology
Breccia in sandstone mattix

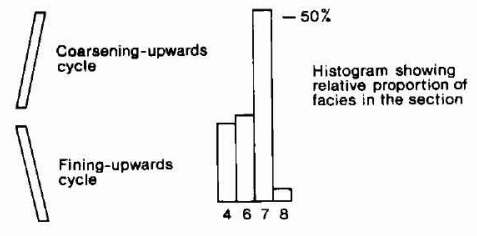

1: Dark mudstone

2: Light grey mudstone

3: Red mudstone

4: Interlaminated mudstone and fine-grained sandstone

5: Graded sandstone with subhorizontal base

6: Structureless non-graded sandstone

7: Graded sandstone deposited in channels

8: Conglomerate

9: Stratified pebble conglomerate

10: Breccia 
Section 5. Midfan association

- outer fan transition. Coastal

cliff south of the mouth of

Laugeites Ravine, western

Kuhn $\varnothing$. Laugeites Ravine

Member; Middle Volgian.

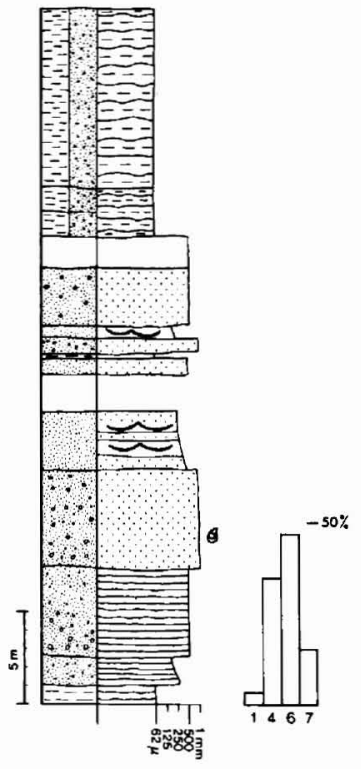

Section $15^{1}$. Inner fan channel association. Niesen, north Wollaston Forland. Rigi Member; Volgian.

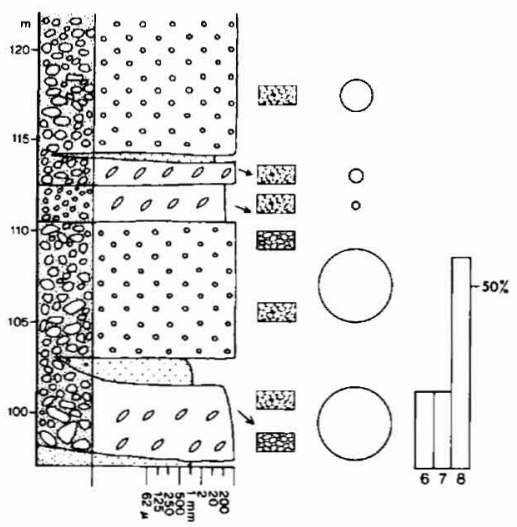

Section 13. Outer fan association. Eastern Kuhn Ø.

Albrechts Bugt-Rødryggen

Member transition; Valanginian.
Section 7. Midfan

association. Coastal cliff

north of the mouth of

Laugeites Ravine, western

Kuhn Ø. Laugeites Ravine

Member; Middle Volgian.
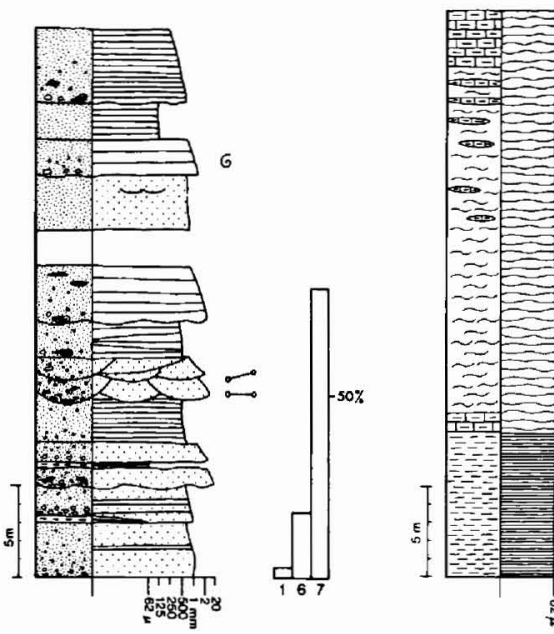

Section 10. Outer fan to basin association. Perisphinctes

Ravine, eastern Kuhn Ø;

Albrechts Bugt-Rødryggen

Member transition; Valanginian.
Section $15^{3}$. Midfan association. Rigi Member; Upper Ryazanian. The sequence is measured in a narrow creek where lateral wedging of beds could not be observed directly. Examination of small closely situated outcrops adjacent to the section revealed, however, that almost all beds were deposited in shallow channels. Note the dominance of fining-upwards cycles.

Section $15^{2}$. Inner fan channel association. Rigi Member; Ryazanian (?).
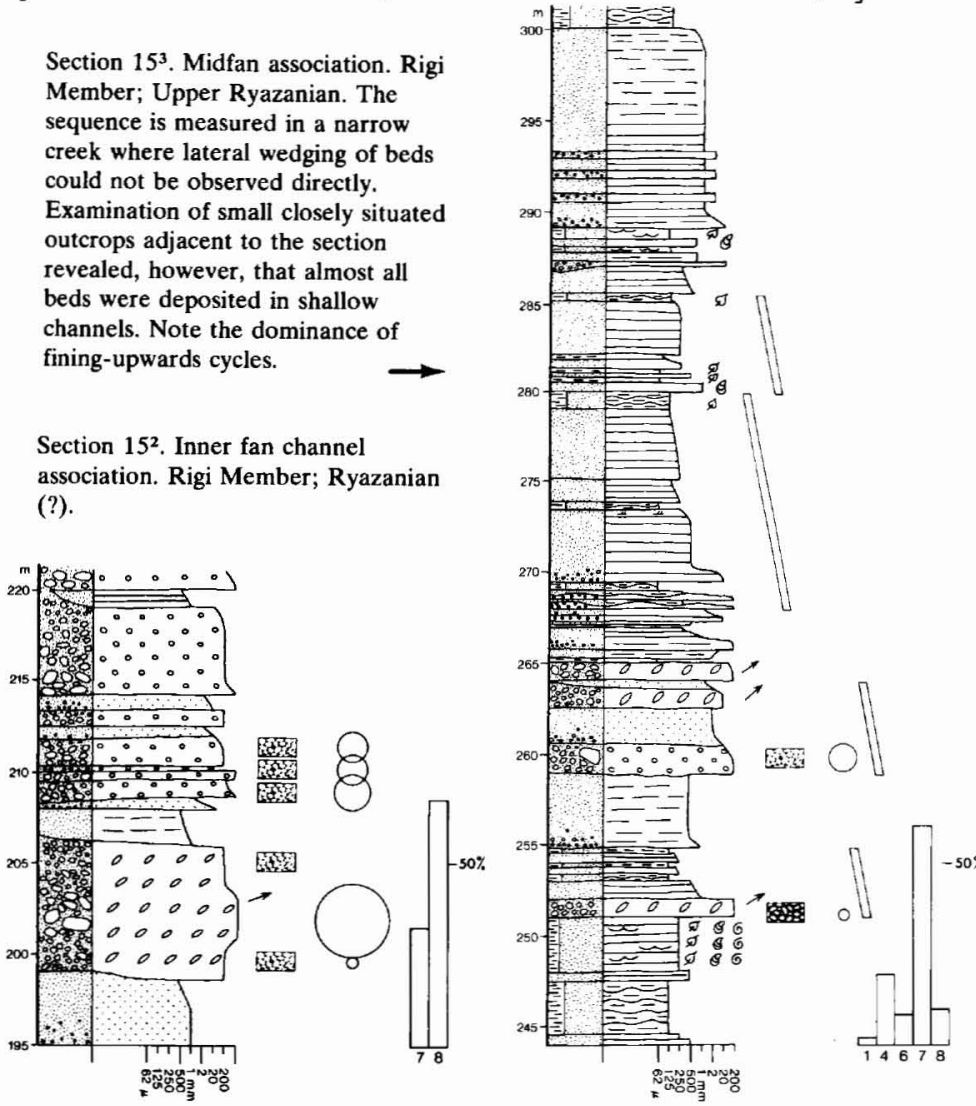
Section $14^{1}$. Inner fan channel association. Niesen, north Wollaston

Forland. Rigi Member; Volgian.
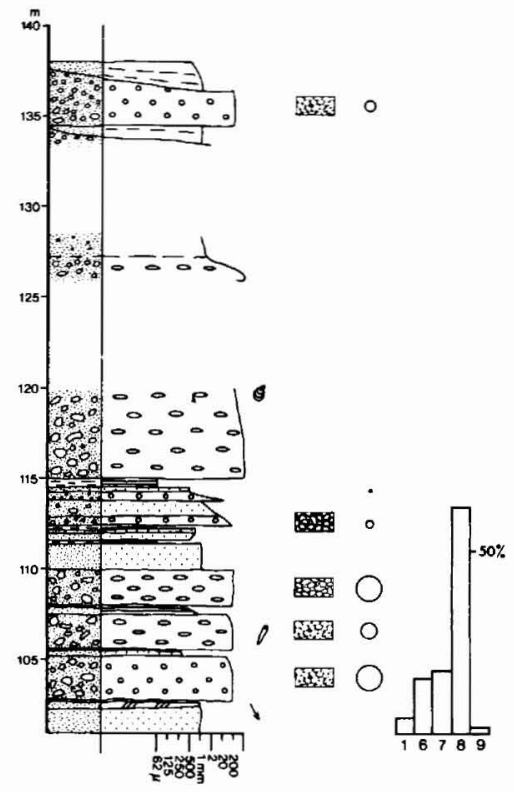

Section $15^{4}$. Inner fan channel association. Rigi Member; Upper Ryazanian. Sequence somewhat more channelled than shown (see remarks to section $15^{3}$ ).
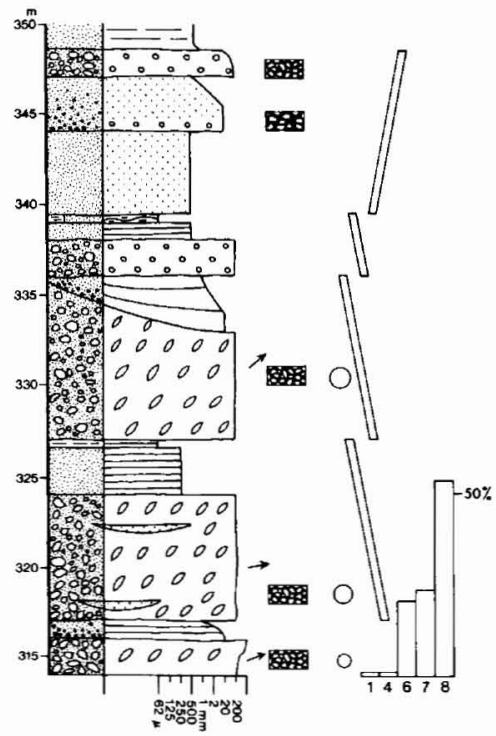

Section $14^{2}$. Transition between inner fan channel and midfan association. Rigi Member; Lower Ryazanian.

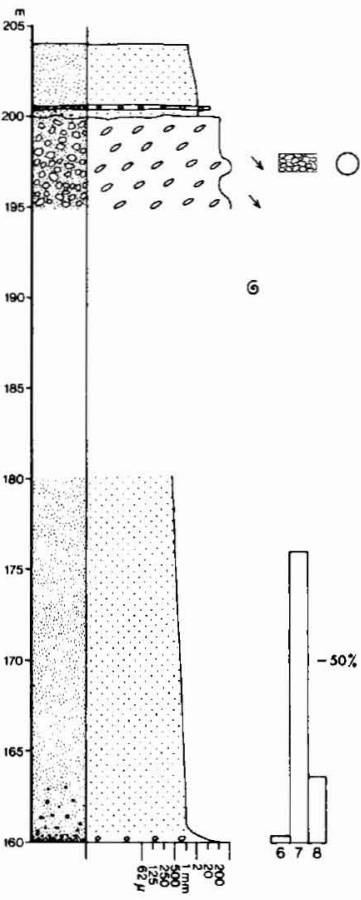

Section $14^{3}$. Inner fan

interchannel-midfan association.

Rigi Member; Lower-Middle(?) Ryazanian.

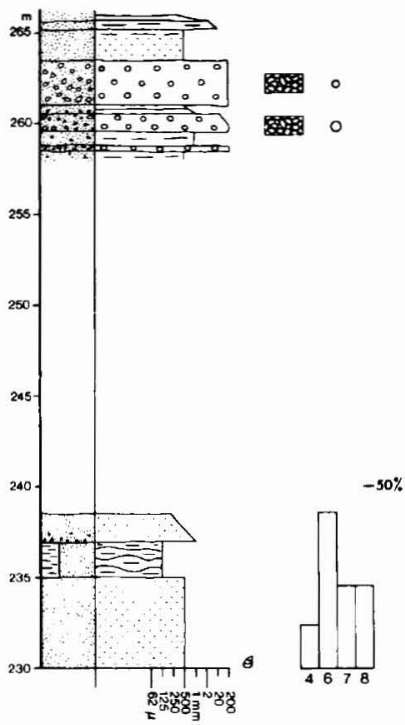

Section 17a. Proximal midfan association. Note the two prominent fining-upwards cycles. Niesen, north Wollaston Forland. Note larger scale than other sections. Rigi Member.

Section $15^{5}$. Inner fan channel association. Rigi Member; Upper Ryazanian.

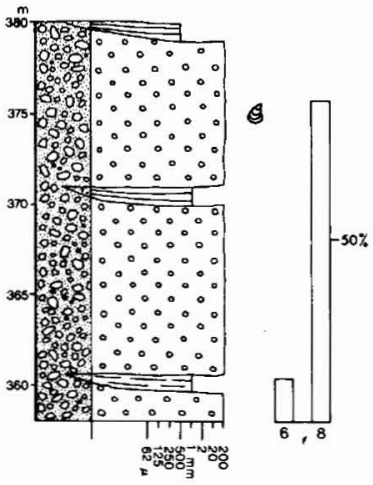

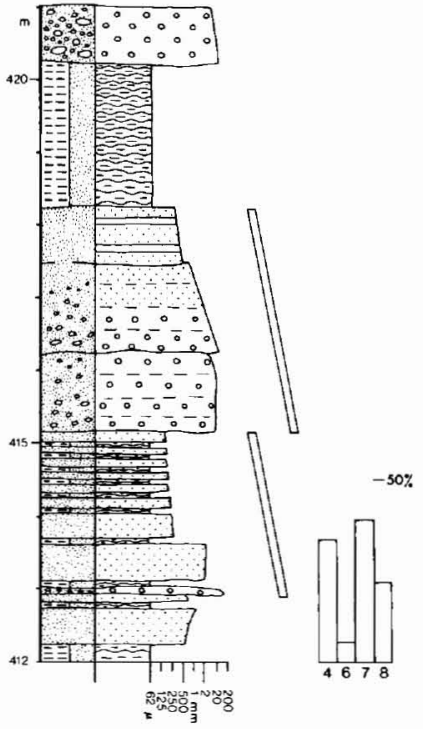


Section $17 b^{1}$. Midfan association. Niesen, north Wollaston Forland. Section more channelled than indicated; see remarks for section $15^{3}$. Rigi Member; Ryazanian.

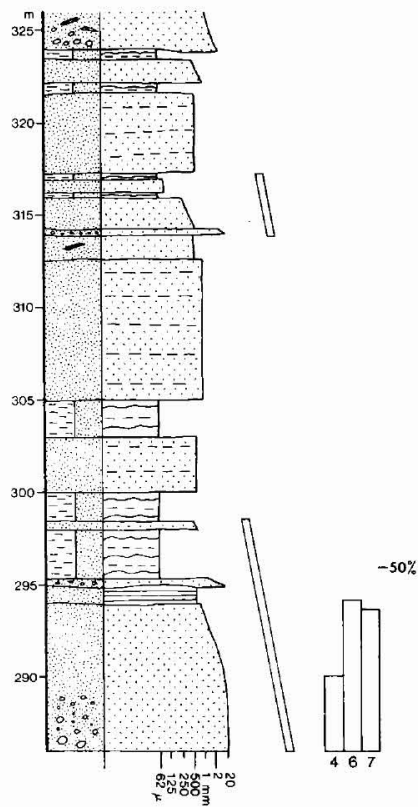

Section $17 \mathbf{b}^{2}$. Midfan association. Section more channelled than shown; see remarks for section $15^{3}$. Rigi Member; Ryazanian. Note the fining-upwards cycles.

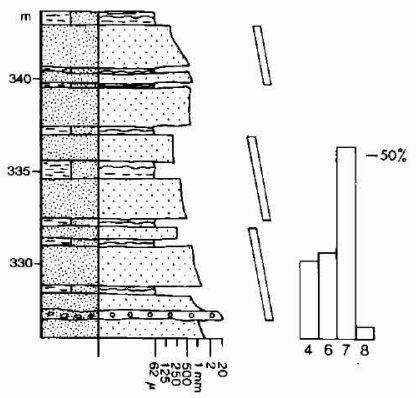

Ravine Member;

Middle-Upper Volgian.

Section 20 is the most fossiliferous section spanning the Jurassic-Cretaceous boundary in the investigated area and forms the basis for

Section $18^{7}$. Transition from outer fan to basin association. Top of mount Niesen. Albrechts Bugt Member; Valanginian.

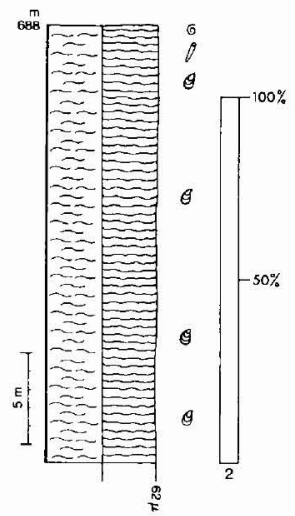

the biostratigraphical zonation

Section 19. Midfan

association. Niesen, north

Wollaston Forland. Rigi

Member; Middle Volgian.

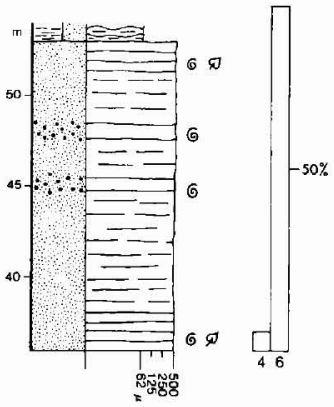

of the sequence. Fig. 5 shows the higher parts of section $20^{1}$, section $20^{2}$ and the base of section $20^{3}$.
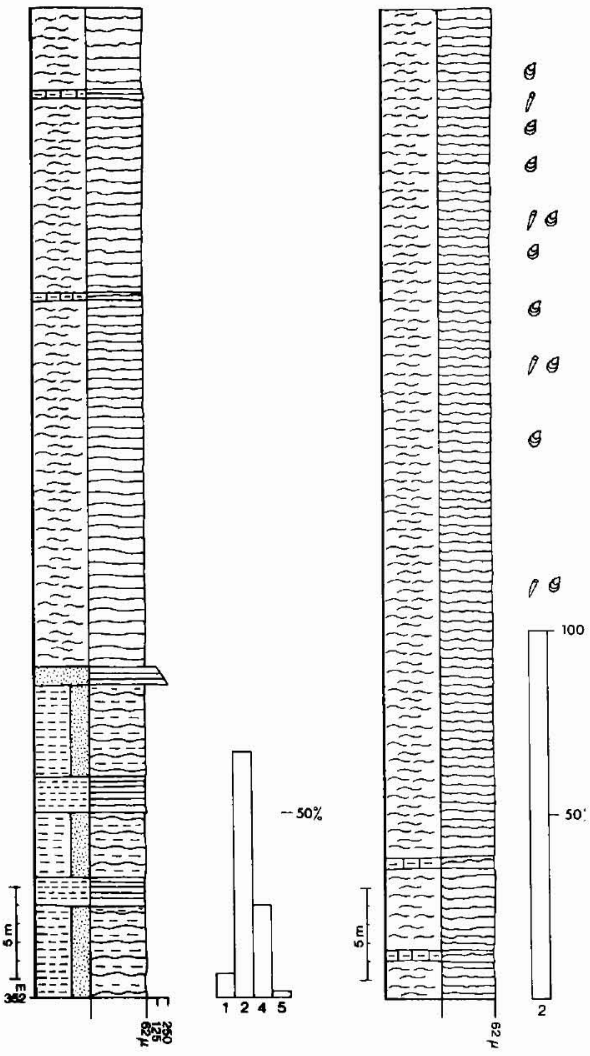

Section $18^{2}$.

Outer fan to basin transition.

Albrechts Bugt

Member;

Valanginian.

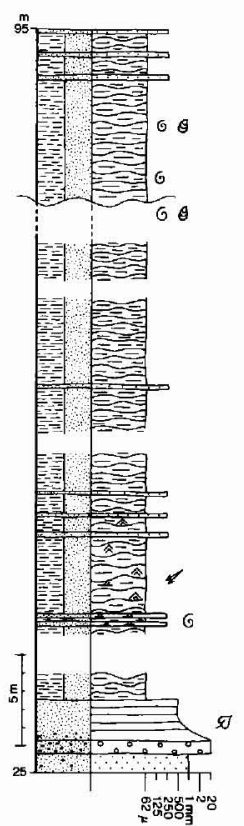

Section $20^{2}$. Midfan associatior Rigi Member; Upper Volgian. This conglomerate-sandstone sequence represents the distal part of the more than $1 \mathrm{~km}$ thick Volgian part of the Rigi Member clastic wedge. In this section the member has thinne to about $75 \mathrm{~m}$ (compare fig. 5 .

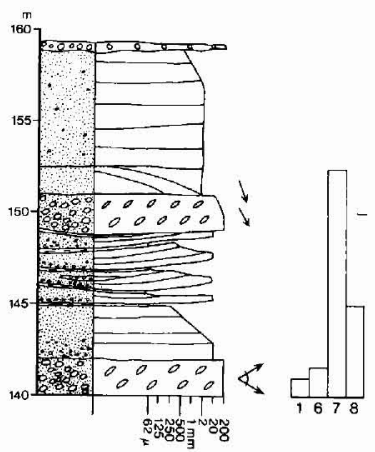



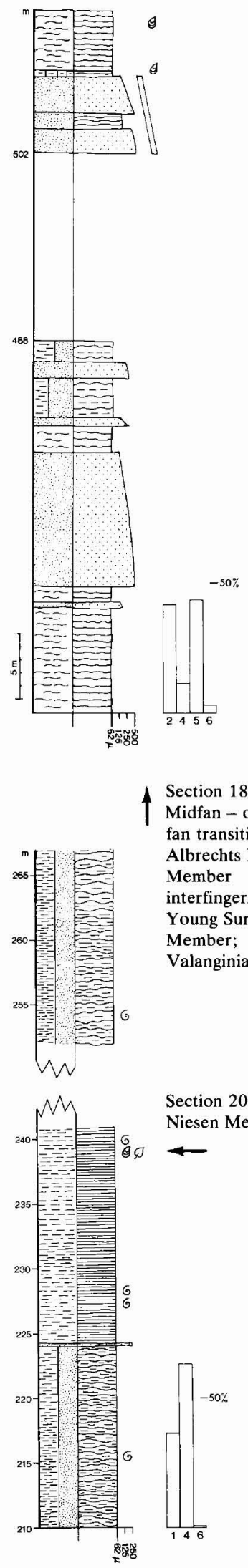

Section $20^{3}$. Outer fan association.

Section $18^{3}$. Section $18^{4}$. Midfan -

Midfan - outer outer fan transition.

fan transition.

Albrechts Bugt

Member

interfingering with

Young Sund

Member;

Valanginian. Interfingering Albrechts Bugt and Young Sund Members; Valanginian.

Section 21. Inner fan channel association. Niesen, north Wollaston Forland. Rigi Member; Middle Volgian.

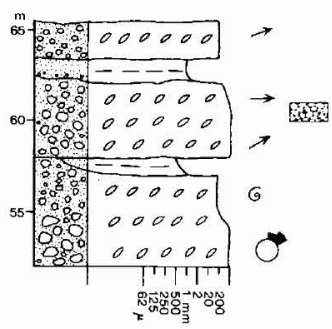

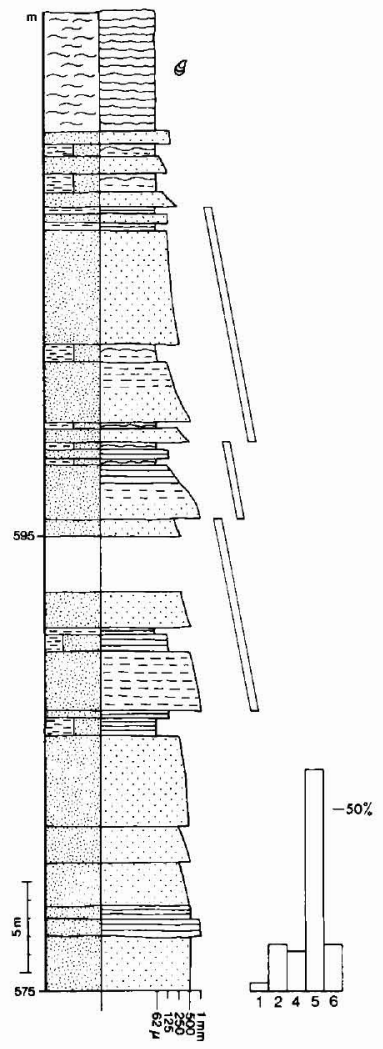

Section $18^{5}$. Midfan association dominated by fining-upwards cycles. Young Sund Member; Valanginian.

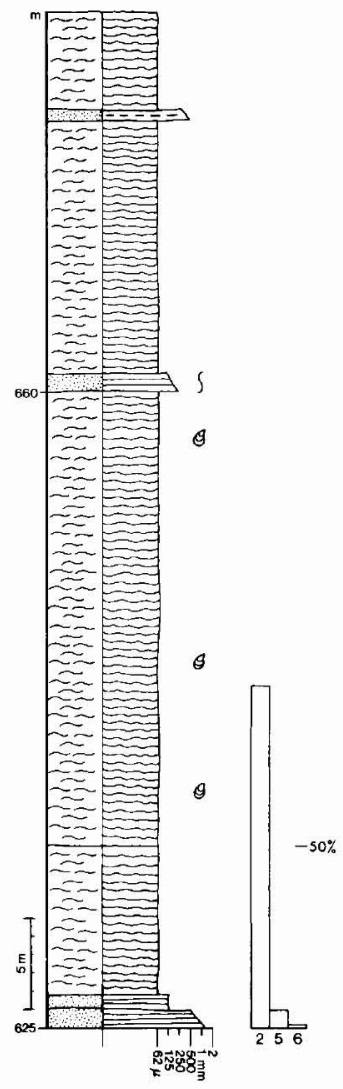

Section $18^{6}$. Transition from outer fan to basin association. Albrechts Bugt Member; Valanginian.

Section 22. Inner fan channel association.

Niesen, north Wollaston Forland. Rigi Member; Volgian.
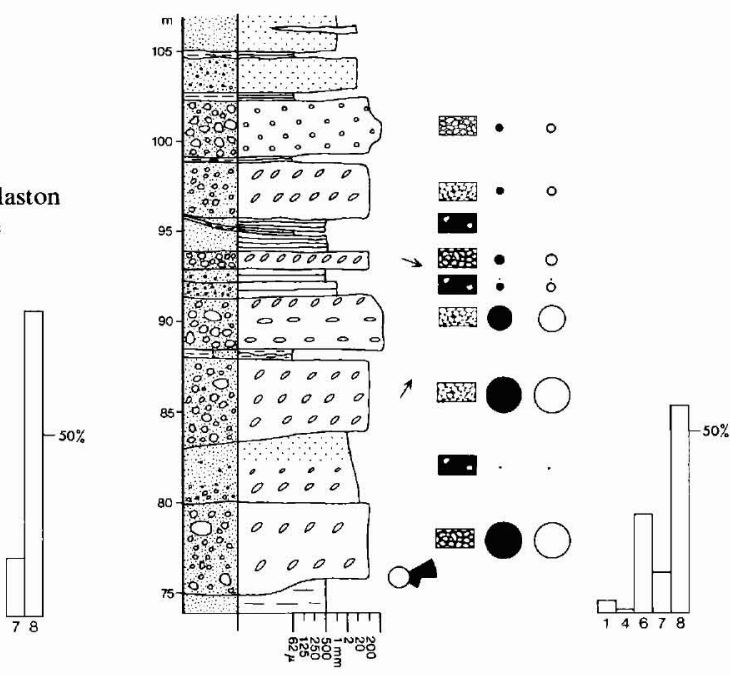
Section 23. Proximal part of midfan association. Niesen, north Wollaston Forland. Rigi Member; Volgian (?).
Section 24. Midfan association.

Niesen, north Wollaston Forland.

Rigi Member; Volgian-Ryazanian.

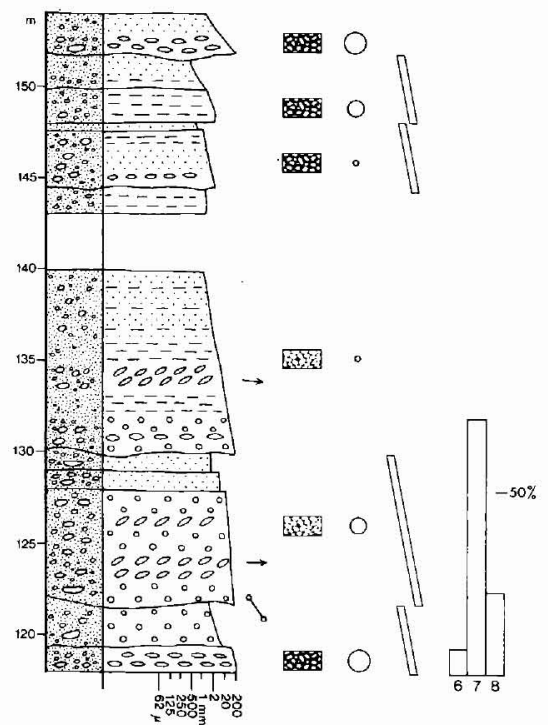

Section 32. Inner fan channel association. See text to section 29. Rigi Member;

Volgian-Ryazanian.

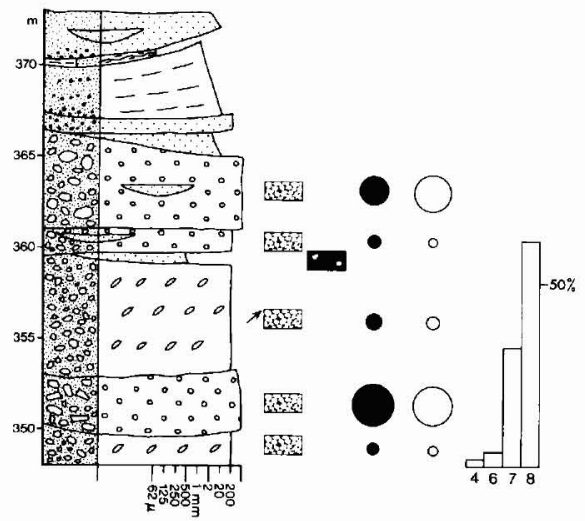

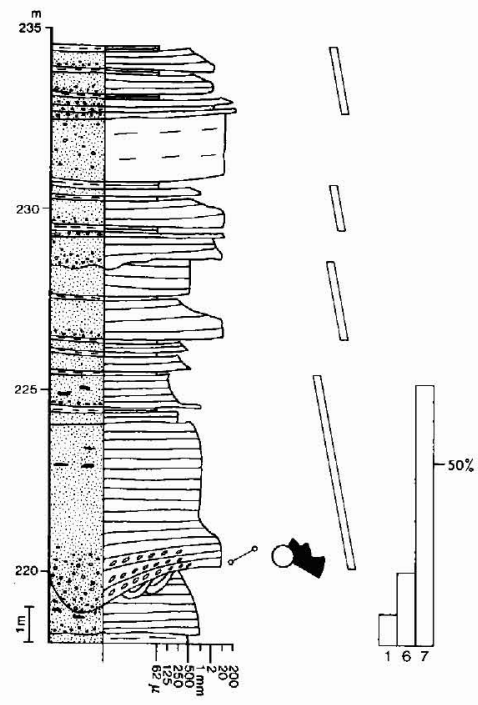

Section 28. Inner fan channel association South side of Niesen, north Wollaston Forland. Rigi Member; Ryazanian (?).

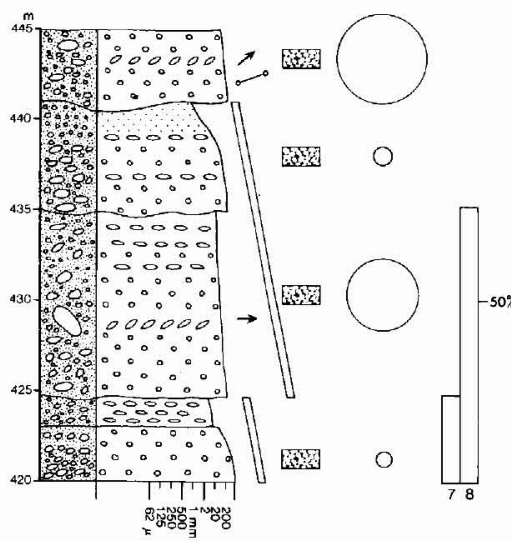

Section 33a. Inner fan channel association passing into midfan association. Measured below section 33 . Rigi Member; Middle Volgian.

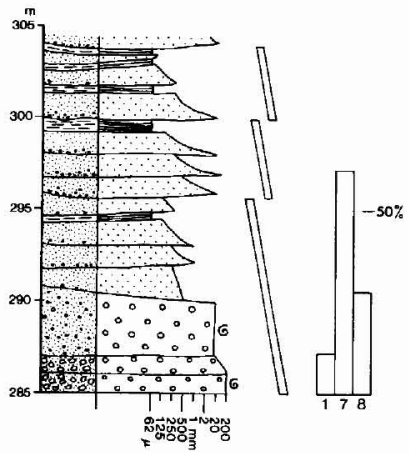

Section 33. Inner fan channel association. See text to section 29. Rigi Member; Volgian-Ryazanian.

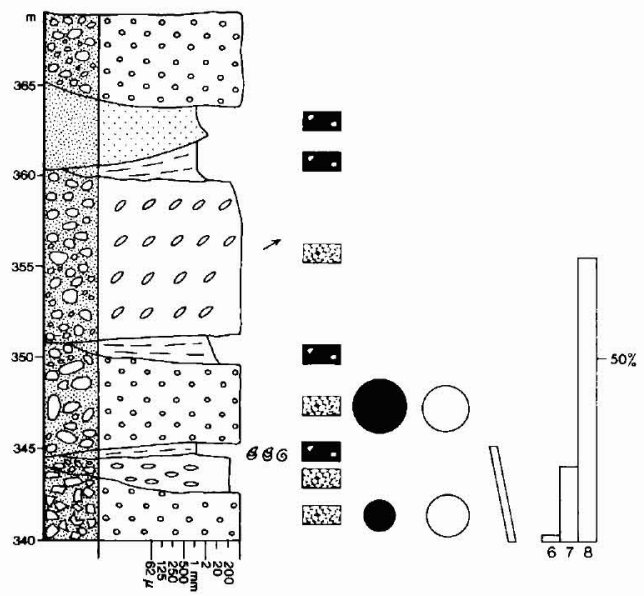




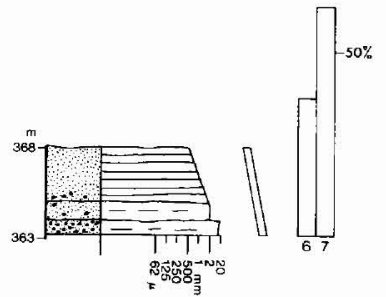

$\uparrow$

Section 29. Inner fan channel association. South side of Niesen. This section and the following sections 30 , 31,32 , and 33 are measured with about $50-80 \mathrm{~m}$ horizontal distance. They are correlated on fig. 39. Rigi Member; Volgian-Ryazanian.
Section 30. Inner fan channel association. See text to section 29. Rigi Member; Volgian-Ryazanian.
Section 31. Inner fan channel association. See text to section 29. Rigi Member; Volgian-Ryazanian.
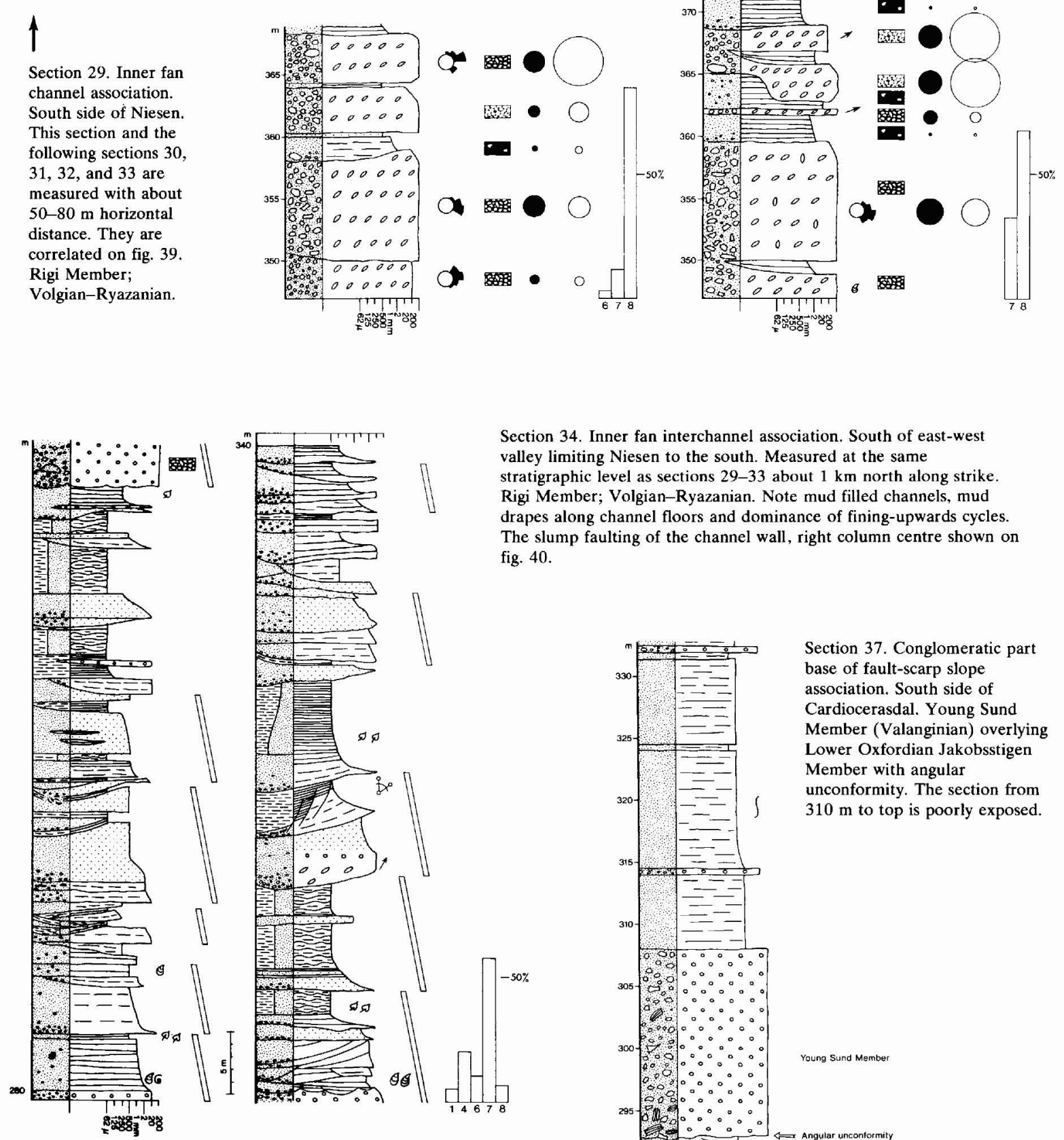

Section 34. Inner fan interchannel association. South of east-west valley limiting Niesen to the south. Measured at the same stratigraphic level as sections $29-33$ about $1 \mathrm{~km}$ north along strike. Rigi Member; Volgian-Ryazanian. Note mud filled channels, mud drapes along channel floors and dominance of fining-upwards cycles. The slump faulting of the channel wall, right column centre shown on fig. 40 .

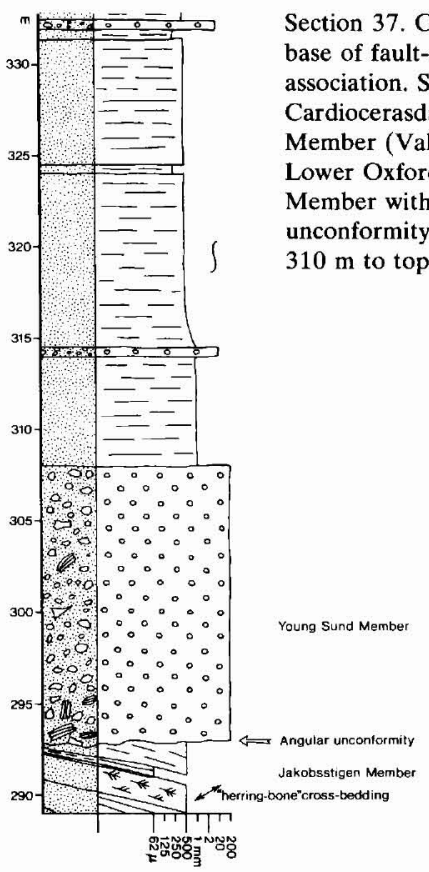




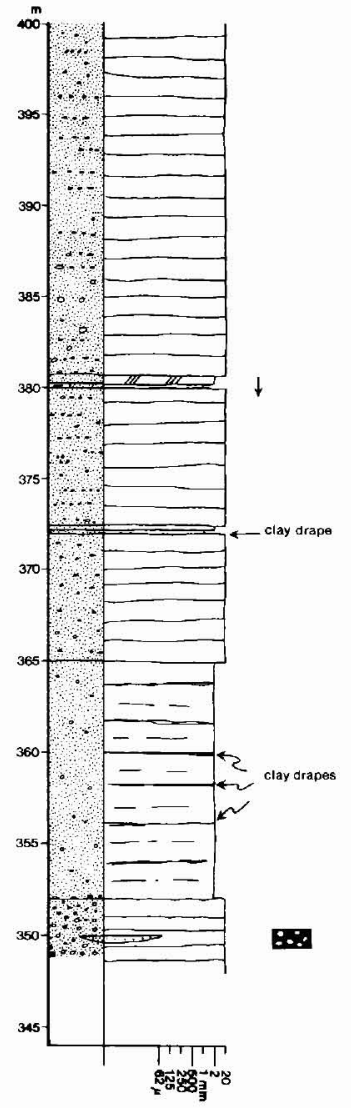

Section $44^{1}$. Clavering $\varnothing$ association (facies association c). Coastal section, east Clavering $\varnothing$, Rigi Member (?).

Volgian-Ryazanian(?).

Section 49. Transition from inner fan channel association below to midfan association at $371 \mathrm{~m}$. NW side of Palnatokes Bjerg, north Wollaston Forland. Rigi Member; Upper Ryazanian. Note the systematic trend from $\mathrm{E}$ to NE orientated palaeocurrents. The same trend also occurs in the neighbouring section 50 .

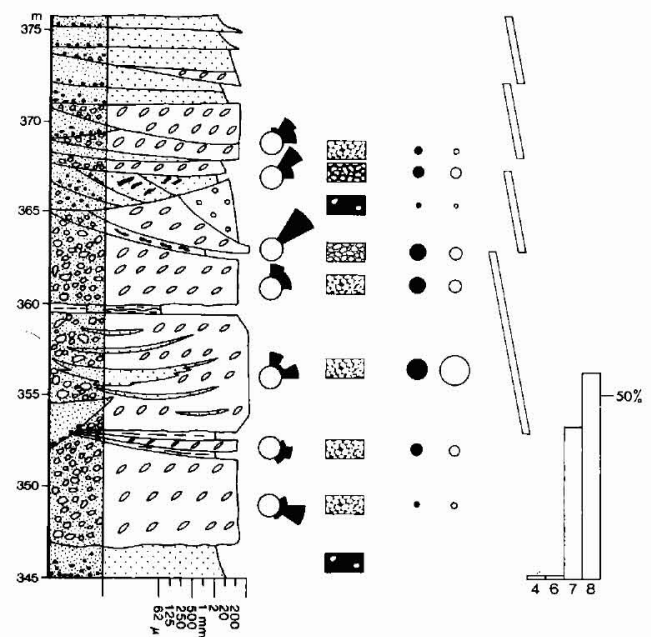

Section $44^{2}$. As for $44^{1}$.

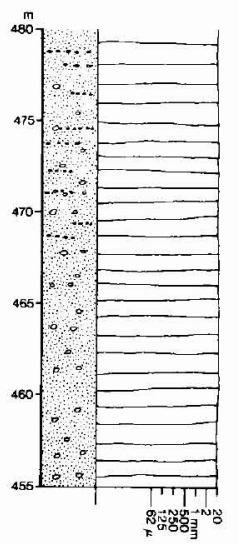

Section $44^{3}$. As

for $44^{1}$.

Section 50. Inner fan channel association up to $390 \mathrm{~m}$, where there is a sharp change to the midfan association NW side of Palnatokes Bjerg, north Wollast on Forland. Rigi Member; Upper Ryazanian. Note the systematic change in palaeocurrent as in section 49 .

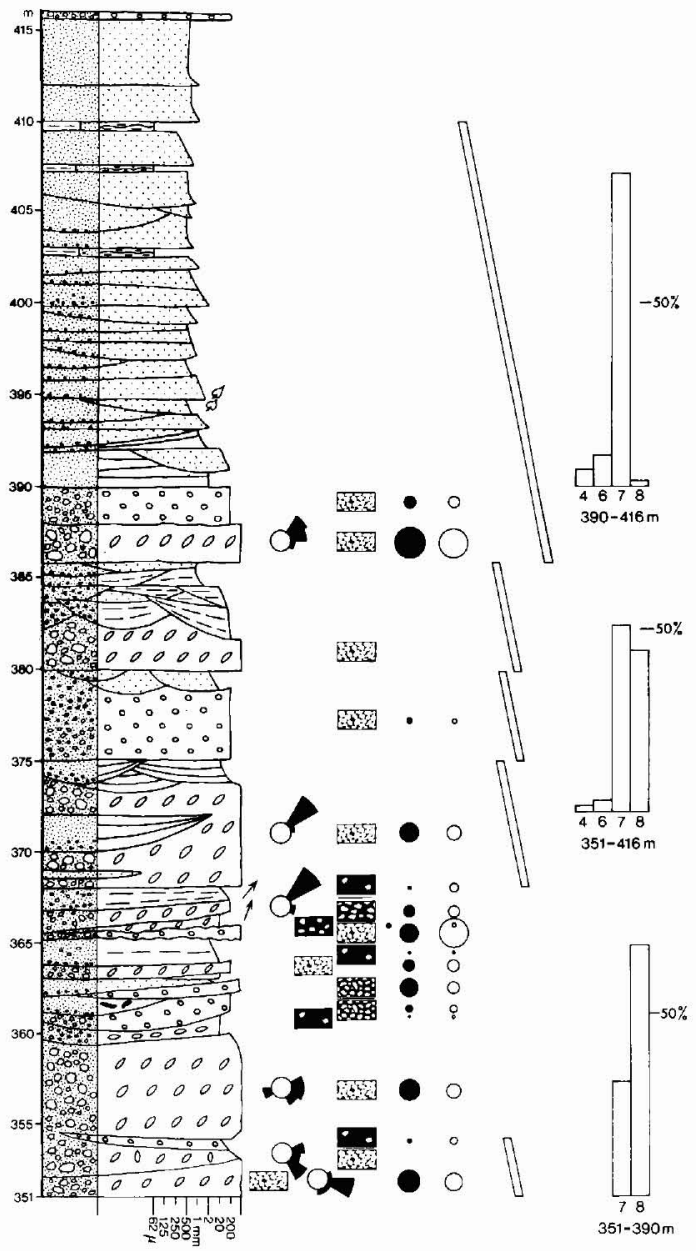




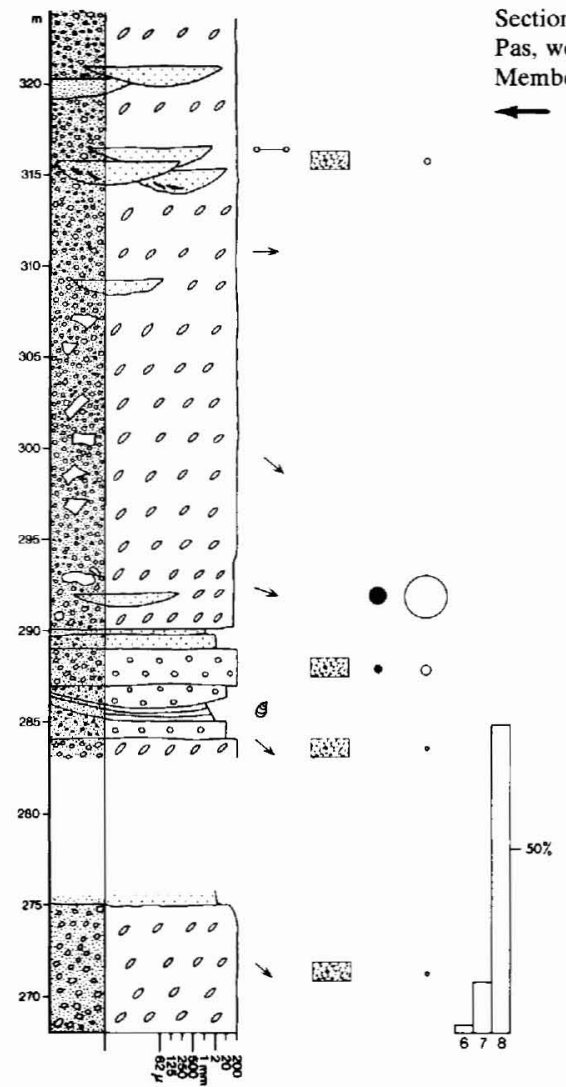

Section 45. Inner fan channel association. Kuhn

Pas, west central Wollaston Forland. Rigi

Member; Volgian (?).

Section 46. Inner fan channel association. Kuhn Pas, west central Wollaston Forland. Rigi Member; Ryazanian(?).
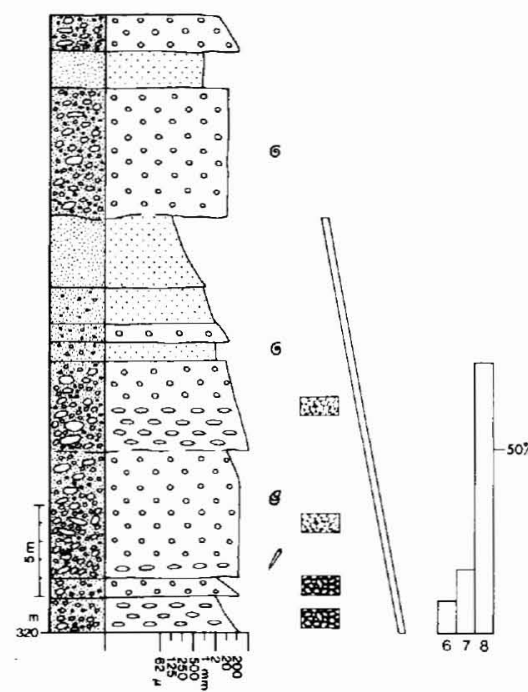

Section 53. Shoal on submerged block crest association. Central Wollaston Forland. The Bernbjerg Formation (Upper Oxfordian-Lower Kimmeridgian) is overlain by Albrechts Bugt-Rødryggen Member facies (Valanginian), which again is overlain by dark Aptian mudstones.
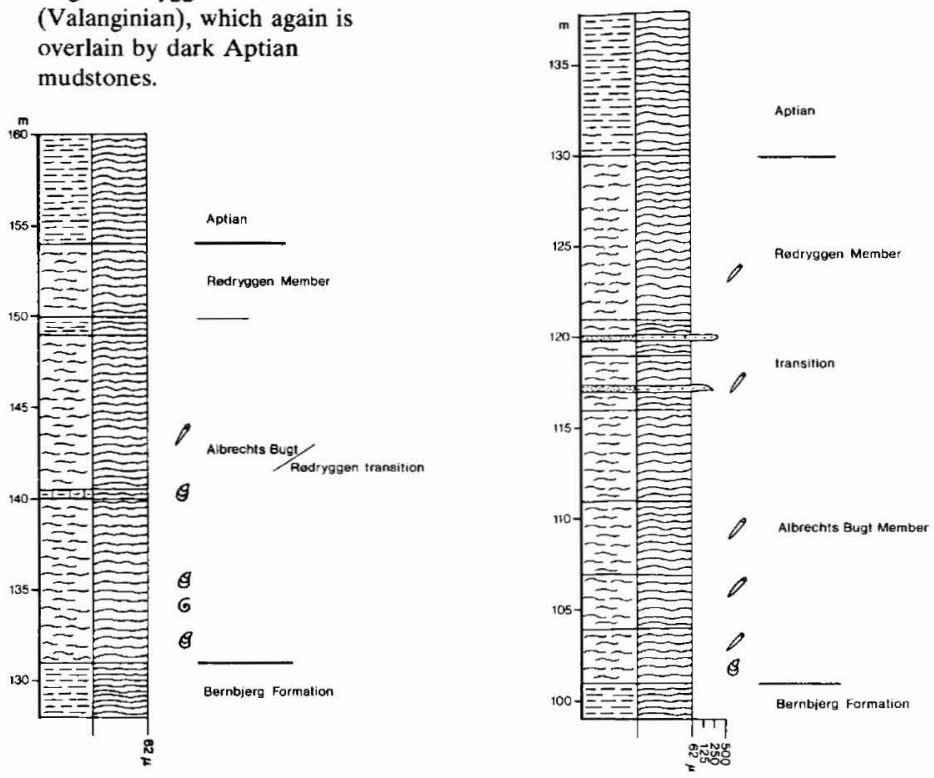

Section 54. Shoal on submerged block crest association. Central Wollaston Forland. Succession like section 53, but Albrechts Bugt Member well developed and passing into Rødryggen Member with a short transition. 


\section{Plate 1}

Laugeites groenlandicus Zone.

Fig. 1. Laugeites groenlandicus (Spath). MGUH 14107 from GGU 139391. Laugeites Ravine Member. Section 20, $52 \mathrm{~m}$ above sea level (Appendix).

Figs 2 a, b. Buchia ex gr. volgensis (Lahusen). MGUH 14108 from GGU 139317. Laugeites Ravine Member. Section 5 at sea level (Appendix).

Figs 3-5. Laugeites parvus Donovan. MGUH 14109 from GGU 139433. Rigi Member. Section 33a, $285 \mathrm{~m}$ above sea level (Appendix). 


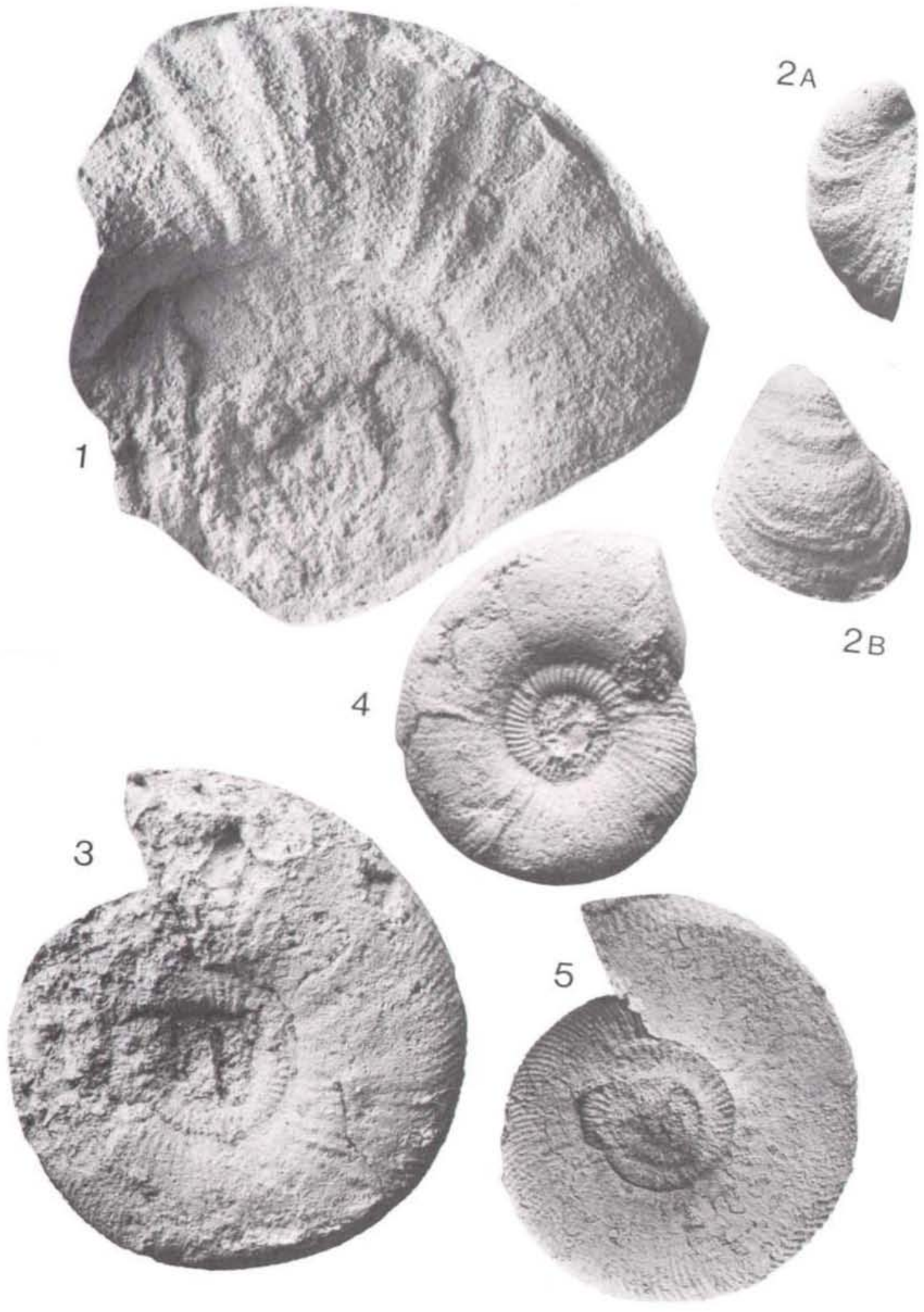




\section{Plate 2}

Laugeites groenlandicus and Epilaugeites vogulicus Zones.

Fig. 1. Pavlovia (Pallasiceras) kochi Spath. MGUH 14110 from GGU 139434. Rigi Member. Section 33a, $290 \mathrm{~m}$ above sea level (Appendix).

Fig. 2. Pavlovia (Pallasiceras) cf. rotundiformis Spath. MGUH 14107 from GGU 139391. Laugeites Ravine Member. Section 20, $52 \mathrm{~m}$ above sea level (Appendix).

Fig. 3. Buchia ex gr. volgensis (Lahusen). MGUH 14108 from GGU 139317. Laugeites Ravine Member. Section 5, $10 \mathrm{~m}$ above base of section (Appendix).

Fig. 4. Epilaugeites vogulicus (Ilovaisky). MGUH 14111 from GGU 139393. Laugeites Ravine Member. Section 20, $88 \mathrm{~m}$ above sea level (Appendix). 


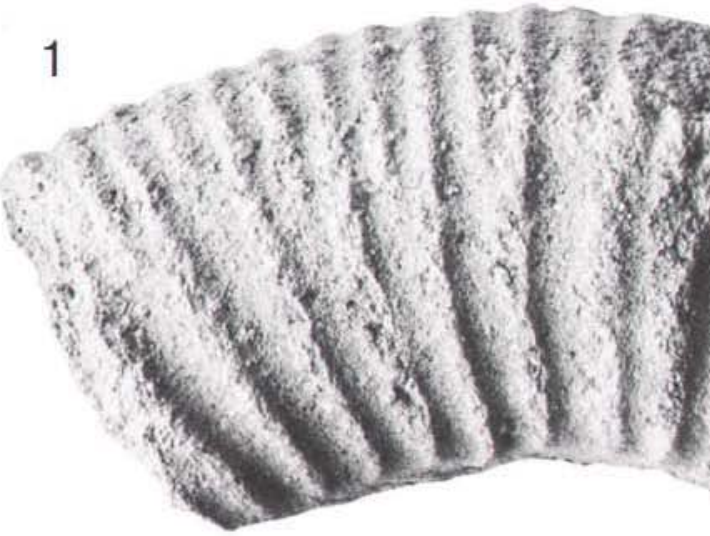

\section{2}

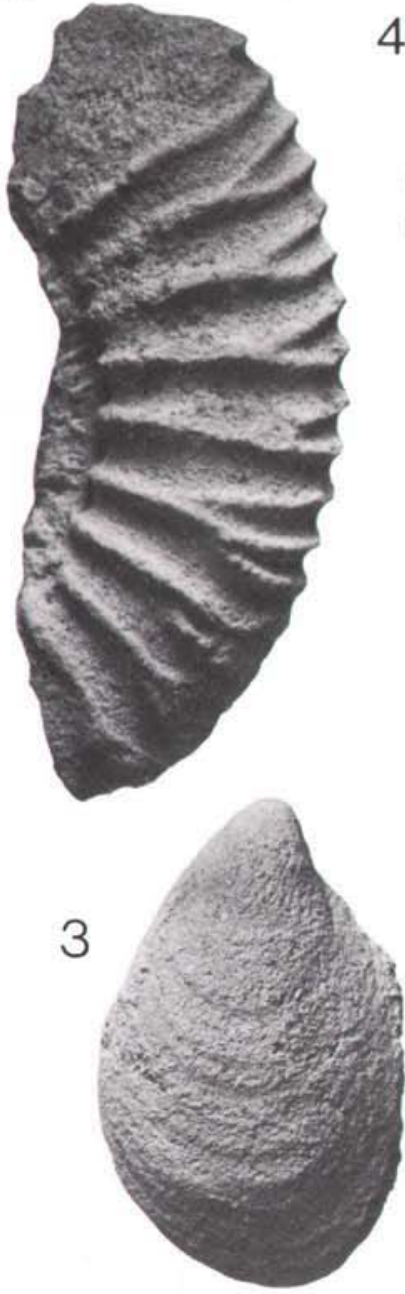

4 aㅏ

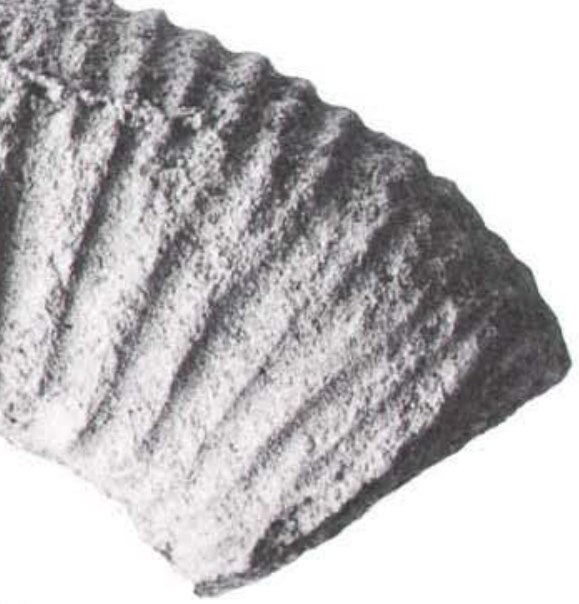

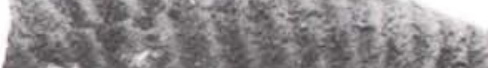

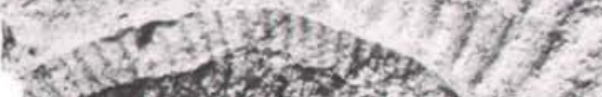

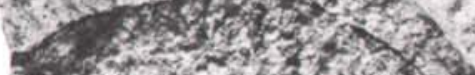

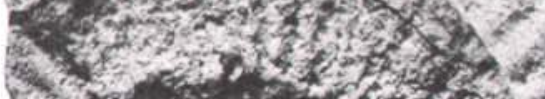

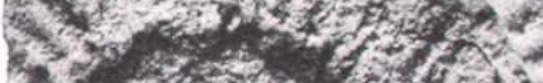

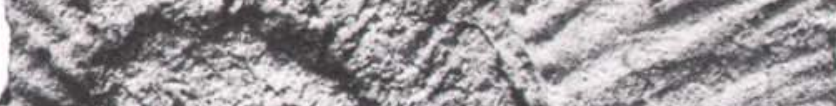

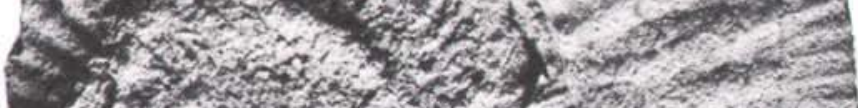

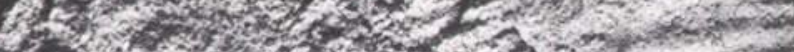

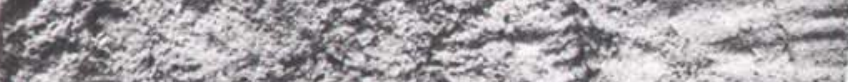

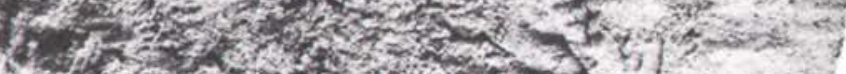

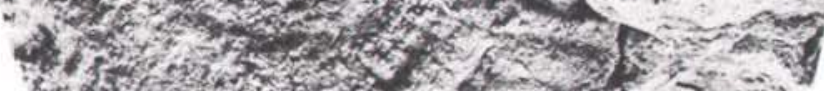

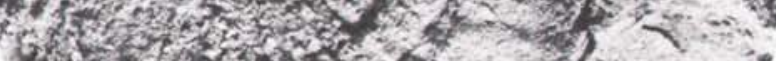

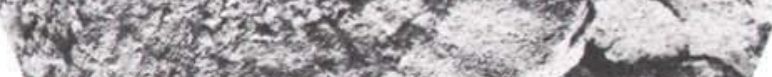

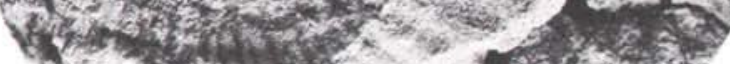
$\frac{1}{3}+f^{2} \cdot x^{2}$ 


\section{Plate 3}

Epilaugeites vogulicus Zone.

Figs 1-4. Epilaugeites vogulicus (Ilovaisky). MGUH 14111 from GGU 139393. Laugeites Ravine Member. Section 20, $88 \mathrm{~m}$ above sea level (Appendix). 

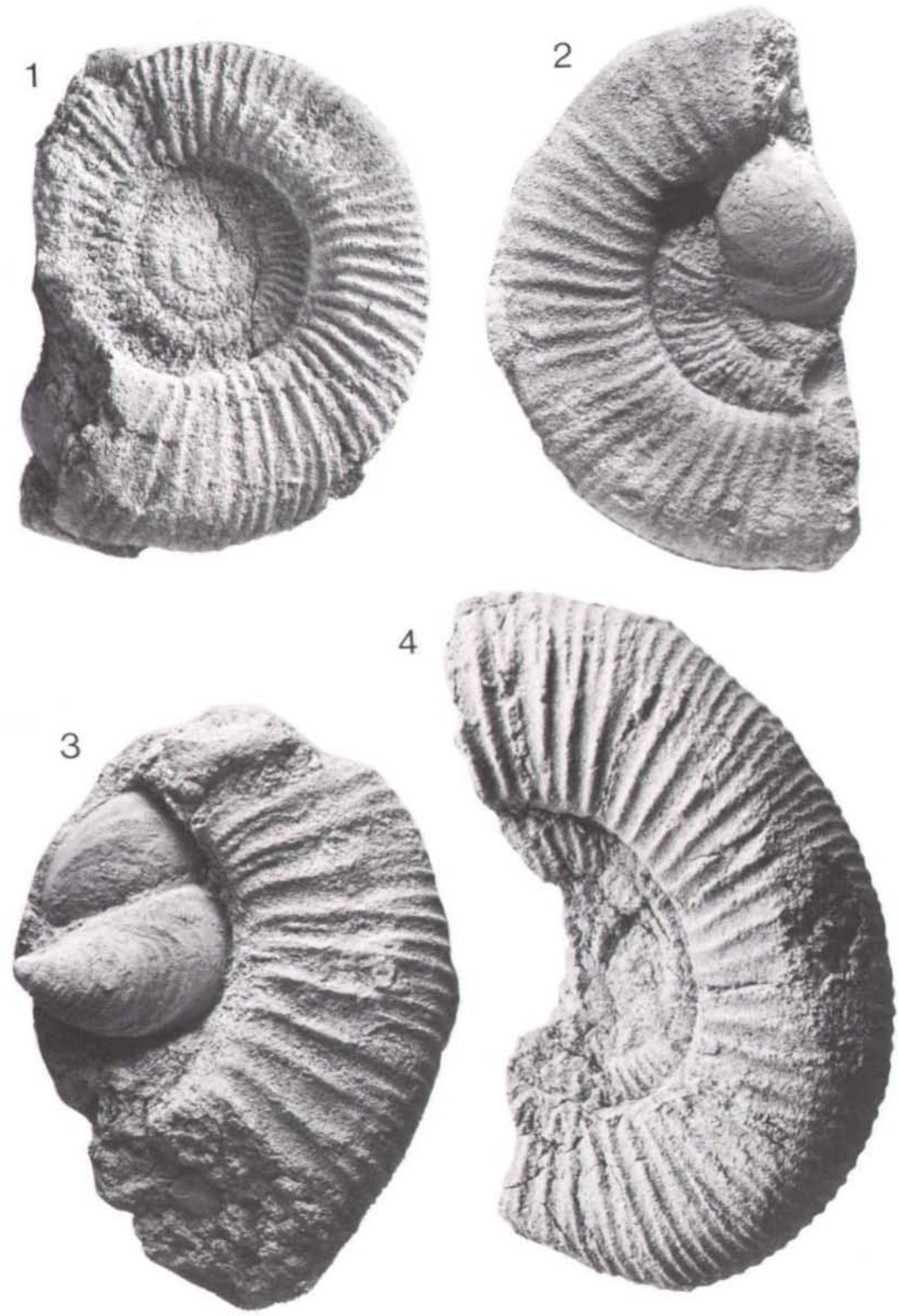


\section{Plate 4}

'Virgatosphinctes' tenuicostatus beds.

Figs 1-3. 'Virgatosphinctes' tenuicostatus Shulgina. MGUH 14112 from GGU 139417. Niesen Member. Section 20, 175-180 m above sea level (fig. 5).

Figs 4-7. 'Virgatosphinctes' tenuicostatus Shulgina. MGUH 14113 from GGU 139437. Niesen Member. South slope of Niesen. $230 \mathrm{~m}$ above sea level.

Fig. 8. Buchia volgensis (Lahusen). MGUH 14113 from GGU 139437. Niesen Member. South slope of Niesen, $230 \mathrm{~m}$ above sea level.

Figs 9-11. 'Virgatosphinctes' cf. bicostatus Shulgina. MGUH 14113 from GGU 139437. Niesen Member. South slope of Niesen, $230 \mathrm{~m}$ above sea level.

Fig. 12. 'Virgatosphinctes' tenuicostatus Shulgina and Buchia aff. fischeriana (d'Orbigny) MGUH 14112 from GGU 139417. Niesen Member. Section 20, $175 \mathrm{~m}$ above sea level (fig. 5). 

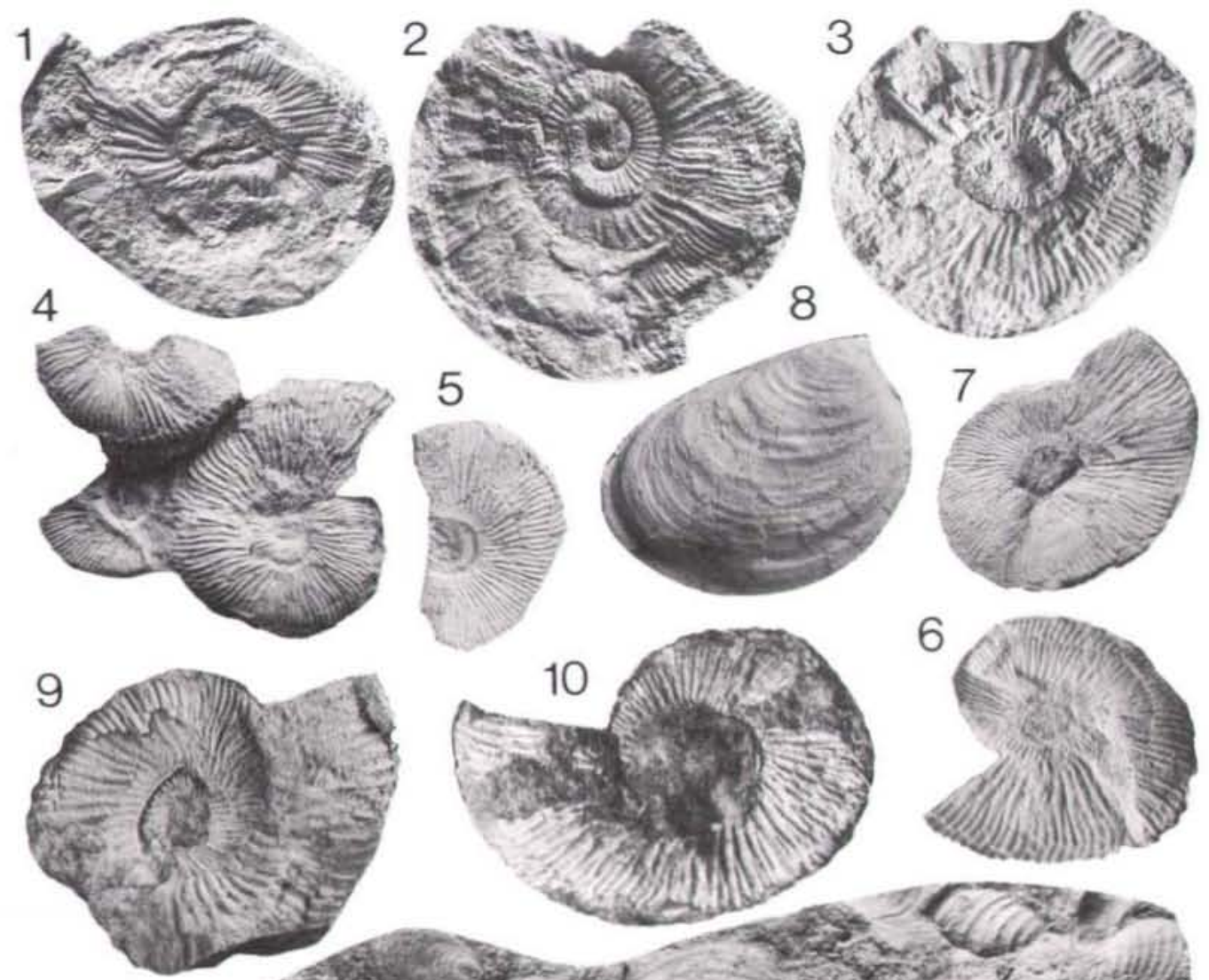

6
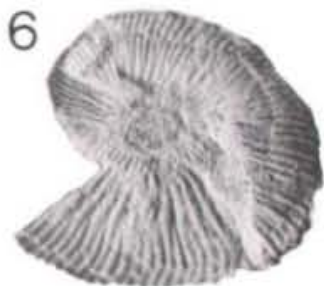

sores

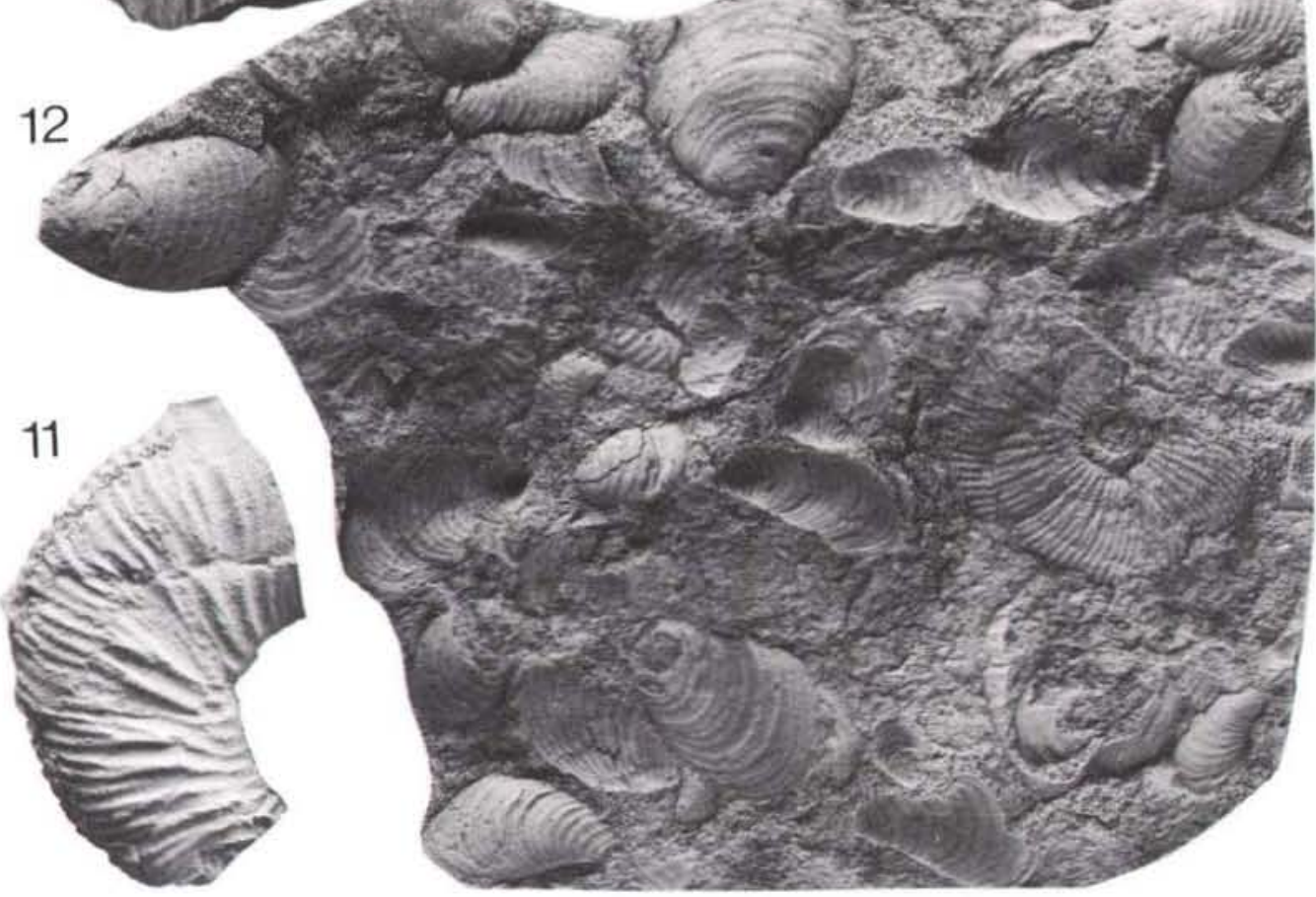




\section{Plate 5}

Praetollia maynci and Hectoroceras kochi Zones.

Figs 1-4. Praetollia maynci Spath. MGUH 14114 from GGU 139402. Niesen Member. Section 20, . $200 \mathrm{~m}$ above sea level.

Fig. 5. Hectoroceras kochi Spath. MGUH 14115 from GGU 139403. Niesen Member. Section 20, 240 $\mathrm{m}$ above sea level.

Fig. 6-13. Pseudocraspedites anglicus (Shulgina). MGUH 14116 from GGU 139418. Niesen - Rigi Member transition. Section 20, $272 \mathrm{~m}$ above sea level. 


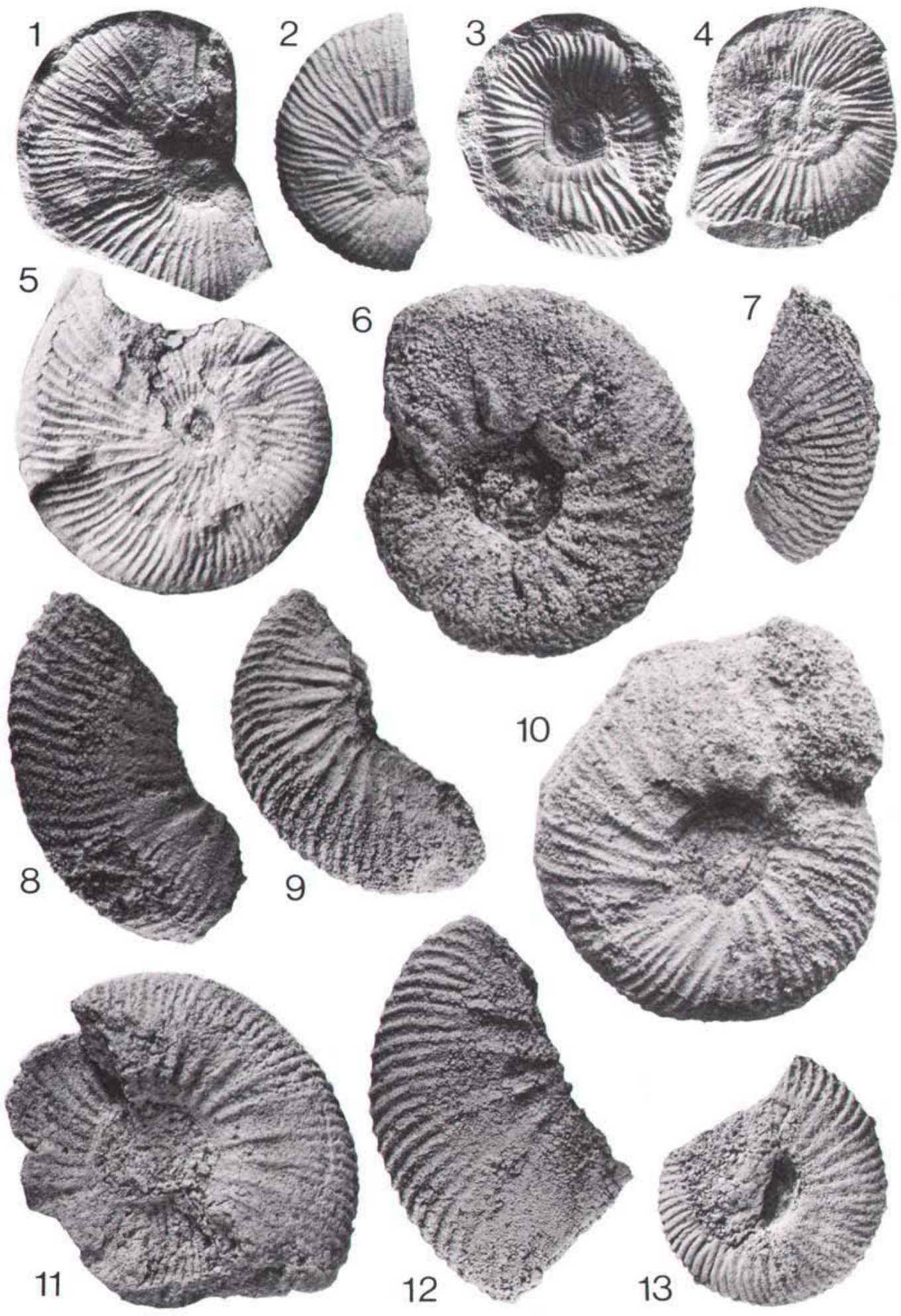




\section{Plate 6}

Surites (Caseyiceras) analogus Zone.

Figs 1-5. Buchia volgensis (Lahusen). MGUH 14117 from GGU 139375. Rigi Member. Section 15², $250 \mathrm{~m}$ above sea level (Appendix).

Figs 6-8. Surites (Caseyiceras) cf. analogus (Bogoslovsky). MGUH 14117 from GGU 139375. Rigi Member. Section $15^{3}, 250 \mathrm{~m}$ above sea level (Appendix). 


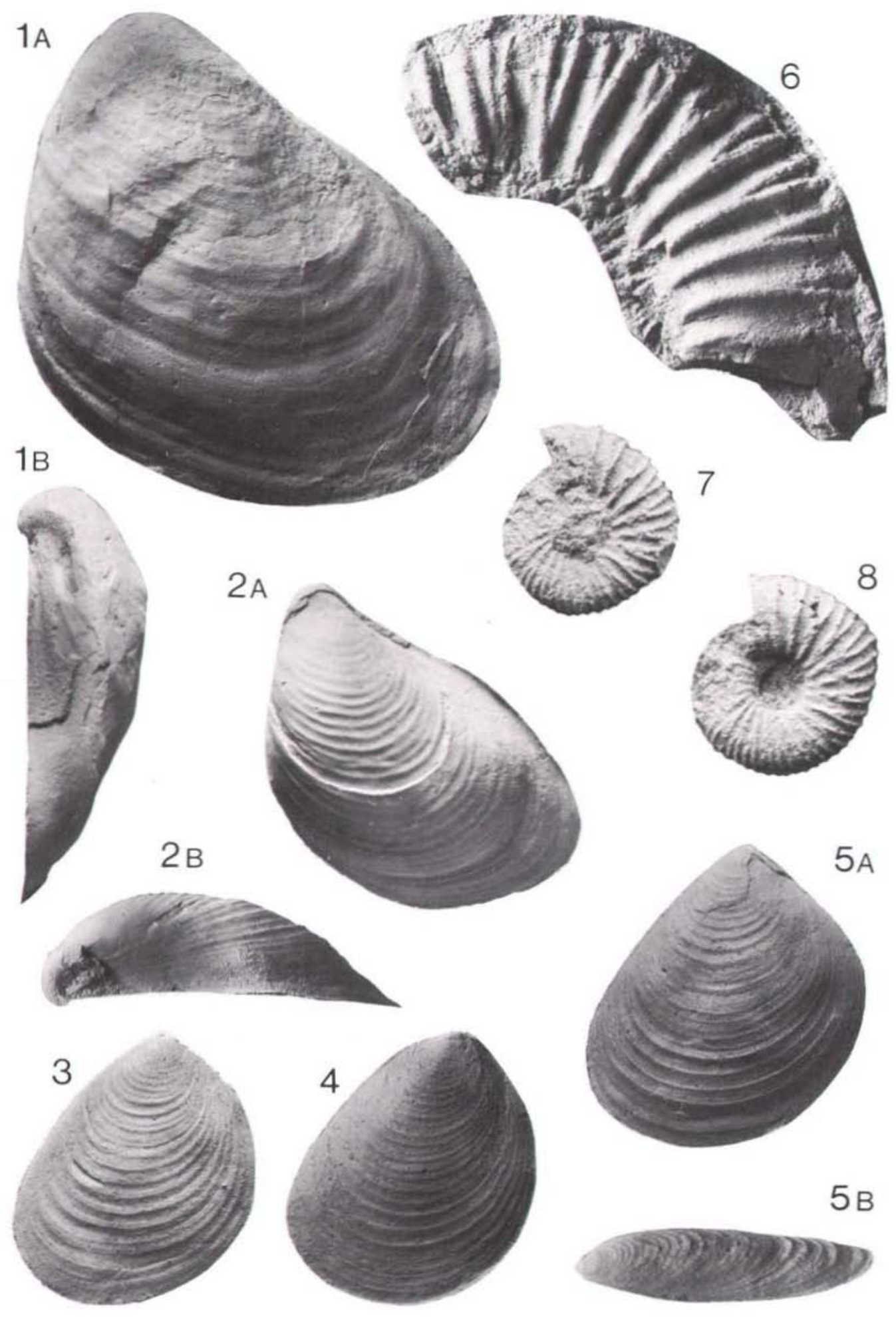




\section{Plate 7}

Surites tzikwinianus, Bojarkia mesezhnikovi and Buchia keyserlingi Zones.

Fig. 1. Surites tzikwinianus (Bogoslovsky). MGUH 14118 from GGU 139408. Niesen - Rigi Member transition. Section 20, $305 \mathrm{~m}$ above sea level.

Figs 2-3. Bojarkia mesezhnikovi Shulgina MGUH 14119-14120 from GGU 139509-139510. Albrechts Bugt Member. Section 50, $451 \mathrm{~m}$ and $454 \mathrm{~m}$ above sea level.

Figs 4-5. Buchia keyserlingi (Lahusen). MGUH 14121 from GGU 139439. Albrechts Bugt Member. North facing slope of E-W valley south of Niesen. $430 \mathrm{~m}$ above sea level.

Fig. 6. Buchia keyserlingi (Lahusen). Long form. MGUH 14122 from GGU 139413. Albrechts Bugt Member. East slope of Palnatokes Bjerg. $530 \mathrm{~m}$ above sea level. 


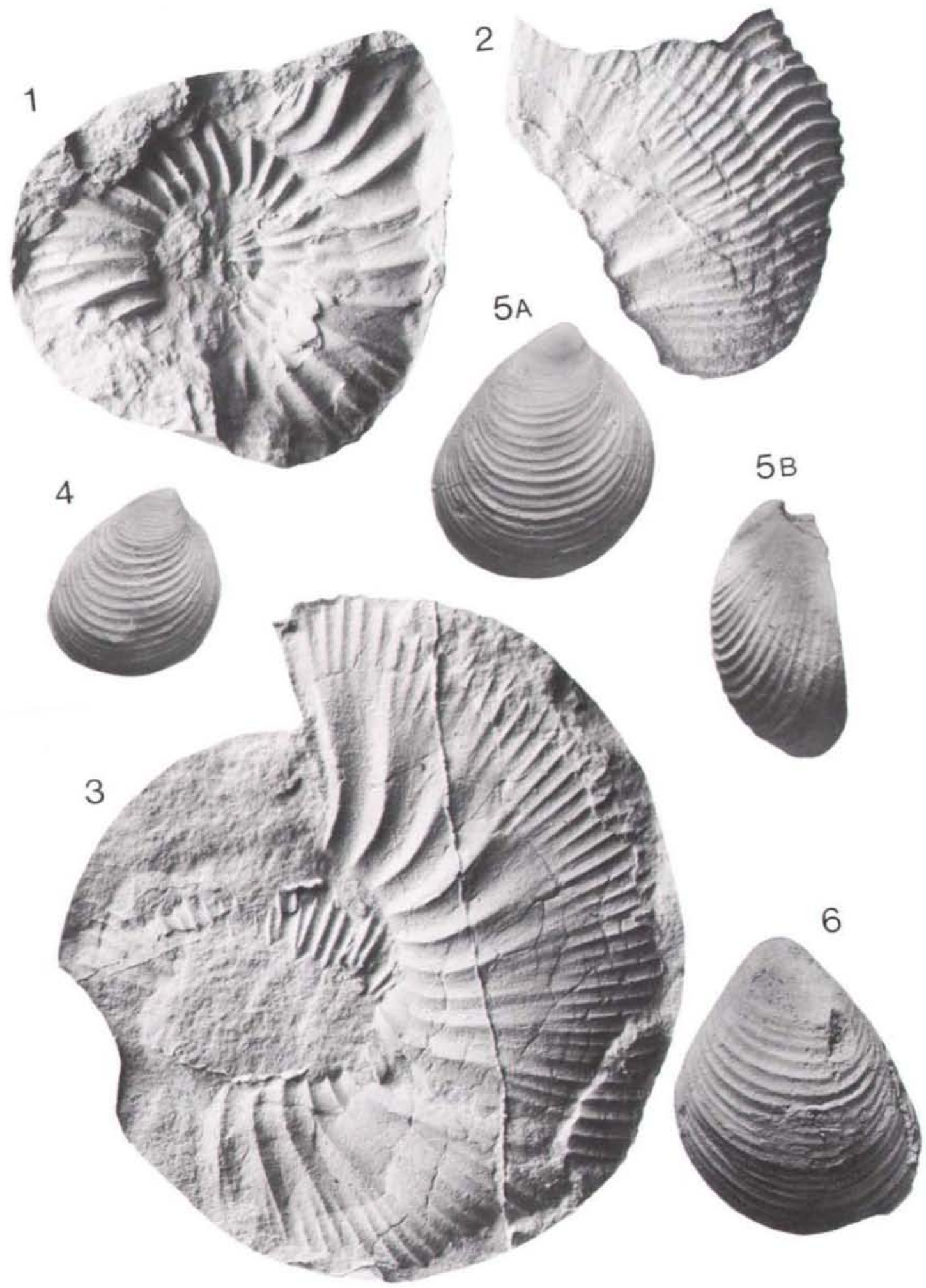




\section{Plate 8}

Tollia tolli, Buchia keyserlingi, Buchia sublaevis and Buchia crassicollis Zones.

Fig. 1. Cf. Tollia tolli Pavlow. MGUH 14123 from GGU 139512. Albrechts Bugt Member. West slope of Palnatokes Bjerg, $478 \mathrm{~m}$ above sea level.

Fig. 2. Polyptychites (Polyptychites) keyserlingi (Neumayr \& Uhlig). MGUH 14124 from GGU 139534. Albrechts Bugt Member. Isolated locality in Sumpdalen, north-eastern Wollaston Forland.

Fig. 3. Buchia sublaevis (Keyserling). MGUH 14125 from GGU 139423. Albrechts Bugt Member. Section $20,635 \mathrm{~m}$ above sea level.

Fig. 4. Buchia keyserlingi (Lahusen) var. gigas (Crickmay). MGUH 14126 from GGU 139519. Albrechts Bugt Member. West side of Rødryggen, loose.

Fig. 5. Buchia crassicollis (Keyserling). MGUH 141127 from GGU 139424. Albrechts Bugt Member. Section 20, $688 \mathrm{~m}$ above sea level, top of Niesen. 


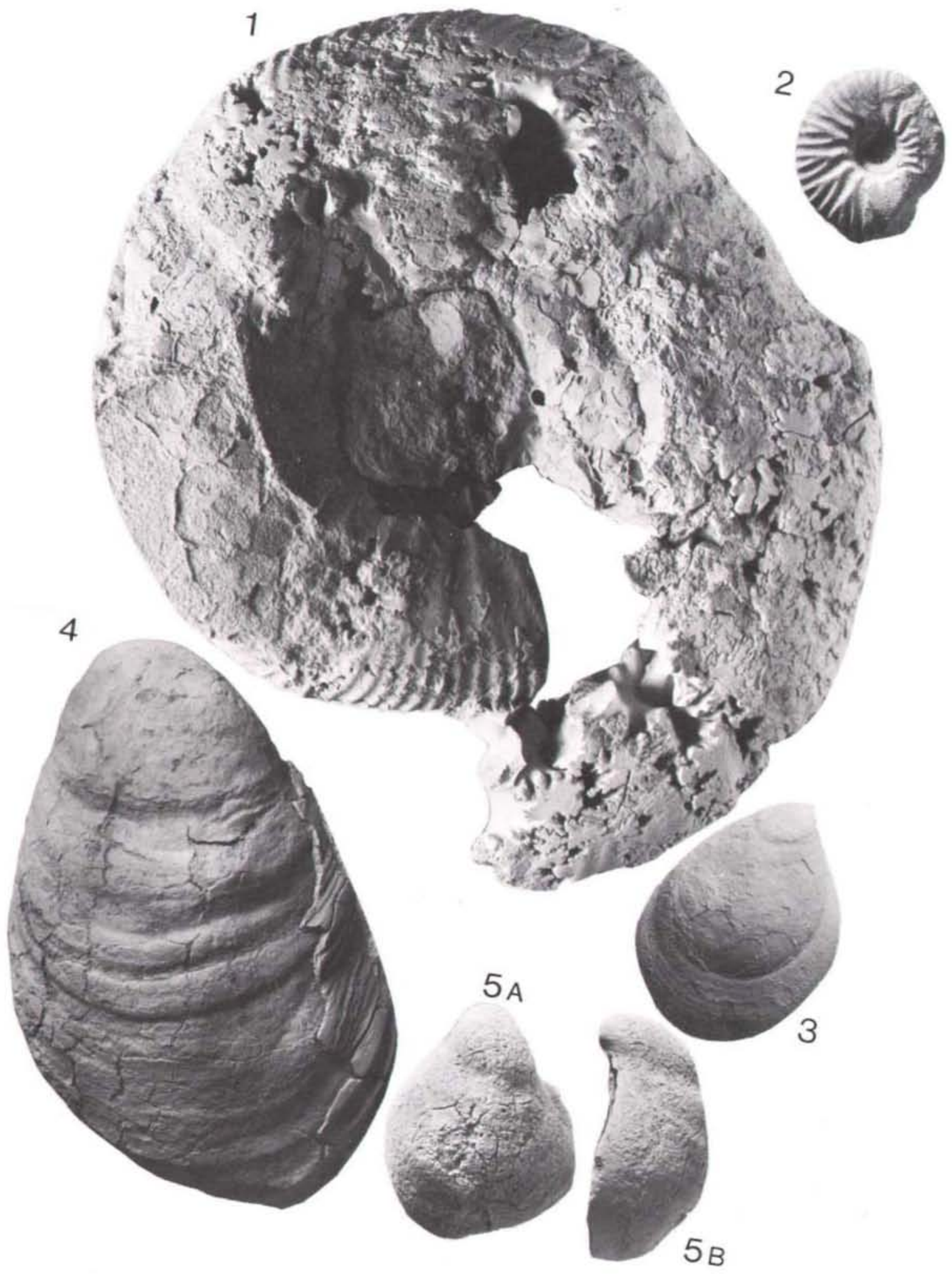




\section{Plate 9}

Geological map of the Wollaston Forland area based on Vischer (1943), Koch \& Haller (1971) and own observations. 


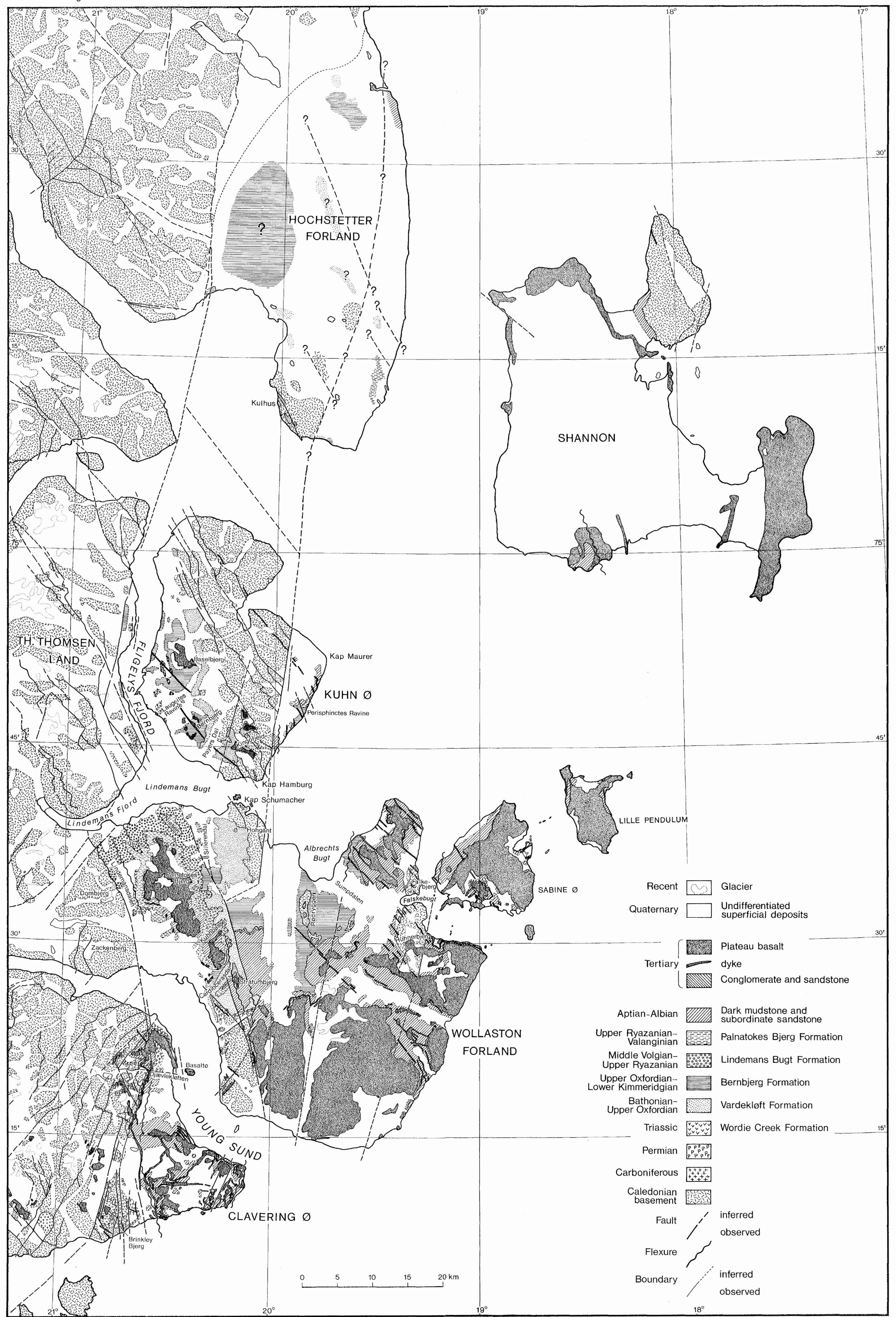

